Universidade de Brasília

Instituto de Ciências Sociais

Departamento de Sociologia

\title{
BUROCRACIA DE ESTADO E POLÍTICAS DE PROMOÇÃO DA IGUALDADE RACIAL
}

\author{
Autora: Maria Aparecida Chagas Ferreira
}

Tese apresentada ao Departamento de Sociologia da Universidade de Brasília/UnB como parte dos requisitos para a obtenção do título de Doutor.

Orientador: Joaze Bernardino Costa

Brasília, novembro de 2014 
Universidade de Brasília

Instituto de Ciências Sociais

Departamento de Sociologia

TESE DE DOUTORADO

BUROCRACIA DE ESTADO E POLÍTICAS DE PROMOÇÃO DA IGUALDADE RACIAL

Autora: Maria Aparecida Chagas Ferreira

Orientador: Joaze Bernardino Costa (UnB)

Banca Examinadora:

Prof. Dr. Joaze Bernardino Costa (Orientador - SOL/UnB)

Prof. ${ }^{\text {a }}$ Dr. ${ }^{\text {a }}$ Leila Giandoni Ollaik (MP)

Prof. Dr. Mário Lisboa Theodoro (Senado Federal)

Prof. Dr. Ivair Augusto Alves dos Santos (GRE/UnB)

Prof. ${ }^{a}$ Dr. ${ }^{a}$ Ana Cristina Murta Collares (SOL/UnB)

Prof. Dr. Artur Trindade Maranhão Costa (Suplente - SOL/UnB) 
Tudo o que não nos destrói, torna-nos mais fortes

Friedrich NIETZSCHE

Não há nada melhor do que as adversidades. Cada derrota, cada mágoa, cada perda, contém sua própria semente, sua própria lição de como melhorar seu desempenho na próxima vez.

Malcolm X 
Ao pessoal lá em casa, Cesa, Nego, Nenê e em especial a minha mãe, Dona Reni.

As minhas crianças, Luan, Letícia e Davi. Obrigada pela paciência e carinho.

Ao Alain, pelo incentivo, por me escutar e por me ajudar com as crianças. 


\section{AGRADECIMENTOS}

A oportunidade que tive ao longo de minha vida de me olhar várias vezes no espelho me trouxe a esta incrível experiência. Agradeço a todos aqueles e aquelas que me fizeram concluir esta etapa da minha vida:

À minha amiga Roselma Évora que de Cabo Verde contribuiu para o meu trabalho com leituras e palavras de ânimos.

À Aleksandra Pereira Santos pela amizade e interlocução sobretudo nos assuntos metodológicos relacionados a minha tese.

Ao Sales Augusto do Santos por ter lançado a fagulha do meu trabalho.

Ao Professor Joaze Bernardino Costa, meu orientador, pela paciência, dedicação e interesse por este trabalho.

À Professora Elaine Rabelo Neiva do Departamento de Psicologia Social e do Trabalho da Universidade de Brasília pelas contribuições inestimáveis para a minha formação.

Aos membros da banca examinadora desta tese que aceitaram participar da conclusão do meu trabalho, professores Leila Giandoni Ollaik, Mário Lisboa Theodoro, Ivair Augusto Alves dos Santos, Ana Cristina Murta Collares e Artur Trindade Maranhão Costa

Aos colegas do Departamento de Sociologia pelo apoio: André Teles Guedes, Natália Caballis, Lauro Stocco, Emerson Ferreira, Mallu Muniz, Pedro Souza, Fábio Bueno, Bernadete Brasiliense.

Aos servidores do Ministério do Planejamento, Orçamento e Gestão que colaboram para que eu pudesse estabelecer contatos com os meus participantes: Keila, Maria do Rosário de Holanda Cunha, Priscila Fátima Pinheiro de Siqueira Bastos, Daniela Guimarães, Márcia Murad.

Aos servidores do Instituto de Pesquisa Econômica e Aplicada-Ipea que me auxiliaram da mesma maneira para o acesso aos meus participantes daquele instituto: Fernanda Lira Goes, Tatiana Dias Silva e Leônidas Pires Neto.

À Professora Maria Teresa Gonzaga Alves da Universidade Federal de Minas Gerais por responder aos meus questionamentos.

À Professora Maria Celina Soares d'Araújo da Pontifíca Universidade Católica do Rio de Janeiro pelos esclarecimentos on-line e o compartilhamento de dados e referências.

À Dra. Raimunda Luzia de Brito pelo constante apoio e auxílio.

Aos amigos pela gentileza e atenção: Valéria, Alexandra, Mauro, Viviane , Romilda, Heloisa, Aleksander, Ena, Flávia, Franck , Josina, Simone, Benjamin, Rosane, Ana, Leila, Socorro, Maris, Benoit, Geralda, Reno, Sandra, Laurent, Maria, Verônica, Marcelo, Maya, 
Jean Pierre, Guy, Regiane, Manuel, Christine, Hubert, Leila, Andre, Jesse, Mireille, Eliane, Naraina. Janaina, Andrea, Mirena, Isabelle, Wanda, Mônica, Francisco, Vinícius (in memoriam) e a tantos outros amigos que passaram em minha vida.

Aos pais e mães da Escola Francesa François Miterrand pela torcida.

À Associação Nacional dos Especialistas em Políticas Públicas e Gestão Governamental, Associação Nacional dos Servidores da Carreira de Planejamento e Orçamento, Associação Nacional dos Advogados da União e Associação Nacional dos Procuradores Federais pelo apoio nos contatos com os participantes da pesquisa.

Ao Natalino pelos alicerces em meu caminho.

À Yvette e ao Henry pelo carinho e interesse.

À Fundação Cultural Palmares, aos seus dirigentes e seus servidores, por terem contribuído para as minhas análises frente à Administração Pública Federal.

Aos professores e aos servidores do Programa de Pós-graduação em Sociologia da Universidade de Brasília. 


\section{RESUMO}

Esta pesquisa apresenta uma análise da baixa capacidade técnica e institucional das políticas de promoção da igualdade racial ao investigar a hipótese de que, sob o ponto de vista sociológico e fundamentos da Teoria da Burocracia Representativa, os indivíduos que pertencem a determinados grupos podem ser portadores das mesmas percepções sobre problemas sociais e podem exercer práticas semelhantes em um mesmo espaço social. A Teoria da Burocracia Representativa se concentra em dois polos: primeiro, a análise da origem social dos servidores públicos, denominada de representação passiva (ou sociológica); segundo, a investigação da representação ativa (ou responsabilidade) em que se espera que o servidor público incline-se favoravelmente aos interesses daqueles que representa, a população em geral ou algum segmento dessa população. Para tanto, buscamos compreender como se posicionam servidores que constituem a alta burocracia das chamadas Carreiras Típicas de Estado por meio da seleção das carreiras de Advogado da União, Analista de Planejamento e Orçamento, Especialista em Políticas Públicas e Gestão Governamental, Técnico de Pesquisa e Planejamento do Instituto de Pesquisa Econômica Aplicada-Ipea e Procurador Federal. A pesquisa explorou a natureza das políticas de promoção da igualdade racial e o apoio desse grupo de servidores às propostas de políticas que beneficiem a população negra. A análise é conduzida por meio de técnicas estatísticas a partir da base de dados primária deste trabalho e das entrevistas concedidas pelos membros dessas carreiras. Os dados obtidos corroboram a tese de que a alta burocracia técnica de que trata este trabalho não possui uma representação passiva e ativa em relação à população negra.

Palavras-chave: Políticas de promoção da igualdade racial, Teoria da Burocracia Representativa, Movimentos Negros, Reconhecimento e Redistribuição. 


\section{ABSTRACT}

This research presents an analysis of the low technical and institutional capacity of policies to promote racial equality. It seeks to investigate the hypothesis that individuals belonging to certain groups can be carriers of same perceptions about social problems and they can have similar practices in the same social environment. These analysis is conducted by a sociological point of view and fundamentals of the Theory of Bureaucracy Representative. The Theory of Bureaucracy Representative focuses on two poles: first, the analysis of the demographic background of civil servants, called passive (or sociological) representation; second, active representation (or responsible) wherein the public servant is expected that lean favorably to the interests of those whom he is presumed to represent, the whole public or some segment of this population. Therefore, we seek to understand the views of the high bureaucracy known as Careers Typical State by selecting the Attorney Careers, Analyst of Planning and Budget, Public Policy and Management Specialist, Technical Research and Planning the Applied Economic Research Institute-IPEA . The research explored the nature of policies to promote racial equality and the support of that civil servant group to policy proposals which benefit the black population. The analysis is conducted using statistical techniques from the primary database of this work and interviews given by members of those careers. The data support the thesis that high technical bureaucracy in this research are not passive and active representativeness in relation to the black population.

Keywords: Policies to promote racial equality, Theory of Bureaucracy Representative, Black Movements, Recognition and Redistribution. 


\section{RÉSUMÉE}

Cette recherche présente une analyse de la faible capacité technique et institutionnelle des politiques de promotion de l'égalité raciale en enquêtant sur l'hypothèse que, du point de vue sociologique et des principes fondamentaux de la Théorie de la Bureaucratie Représentative, les personnes appartenant à certains groupes peuvent être porteurs des mêmes perceptions concernat les problèmes sociaux et peuvent avoir des pratiques similaires dans le même espace social. La Théorie de la Bureaucratie Représentative se concentre sur deux pôles: d'abord, l'analyse de l'origine sociale des fonctionnaires, appelés représentation passive (ou sociologique); Deuxièmement, la recherche de la représentation active (ou responsabilité) qui attend que le fonctionnaire se montre favorable aux intérêts de ceux qu'il représente, la population ou une partie de cette population. Par conséquent, nous cherchons à comprendre comment se positionne les fonctionnaires qui constituent la haute bureaucratie des Carrières d'État en sélectionnant les carrières d'Avocat de l'Union, d'Analyste de la Planification et du Budget, de Spécialiste de la Politique Publique et de la Gestion Gouvernementale, de Technicien de la Recherche et de la Planification de l'Institut de Recherche Économique Appliquée-IPEA et de Procureur Fédéral. La recherche a exploré la nature des politiques visant à promouvoir l'égalité raciale et l'appui que ces groupes de fonctionnaires des propositions de politiques qui profitent à la population noire. L'analyse est effectuée en utilisant des techniques statistiques à partir de la base de données primaire de ce travail et des interviews données de membres de ces carrières. Les données confirment la thèse selon laquelle la haute bureaucratie technique, analysée ce travail, n'a pas obtencies une représentation passive et active par rapport à la population noire.

Mots-clés: Politiques de Promotion de l'Égalité Raciale, Théorie de la Bureaucratie Représentative, Mouvements Sociaux de la Population Noire, la Reconnaissance et la Redistribution. 


\section{SUMÁRIO}

Introdução ................................................................................................................................ 16

Capítulo 1 - Políticas públicas e políticas de promoção da igualdade racial ........... 30

1.1. Políticas de promoção da igualdade racial e o protagonismo do movimento social negro 32

1.2. Políticas de promoção da igualdade racial: além da justiça compensatória, os princípios de reconhecimento e redistribuição .................................................................... 51

1.3. Capacidade técnico-institucional e a responsabilidade compartilhada....................63

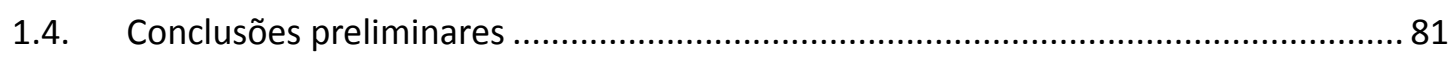

Capítulo 2 - Procedimentos Metodológicos..................................................................... 84

2.1. Respondentes e entrevistados ................................................................. 86

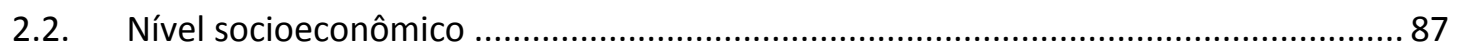

2.2.1. Construção do nível socioeconômico........................................................... 88

Capítulo 3 - Quem são os nossos participantes ............................................... 94

3.1. Analista de Planejamento e Orçamento-APO ................................................ 95

3.2. Especialista em Políticas Públicas e Gestão Governamental-EPPGG ........................ 95

3.3. Técnico de Planejamento e Pesquisa do Ipea ......................................................97

3.4. Carreiras Jurídicas - Advogado da União e Procurador Federal..............................97

3.5. Origem social dos participantes .................................................................. 104

3.5.1. Cor e/ou raça ................................................................................. 104

3.5.1.1. Não concordo com a classificação de cor/raça do IBGE ......................... 105

3.5.2. Sexo e faixa etária ........................................................................ 113

3.5.3. Interpretação da origem social ........................................................... 114

3.6. Os participantes entrevistados .............................................................. 117

Capítulo 4 - O papel da alta burocracia técnica ........................................................... 120

4.1. Burocracia representativa ............................................................... 120

4.2. A alta burocracia técnica (política) e seu espaço de atuação ................................ 126

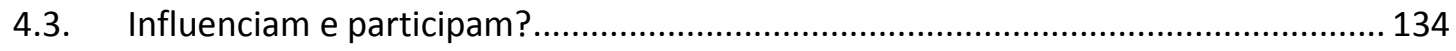

4.4. O processo de decisão das políticas públicas e o papel da burocracia ................... 148

4.5. Conclusões preliminares ................................................................. 149

Capítulo 5 - Teoria da burocracia representativa e análise de variáveis ............. 152

5.1. Conceitos e operacionalização das variáveis ................................................. 163

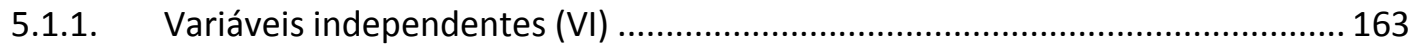

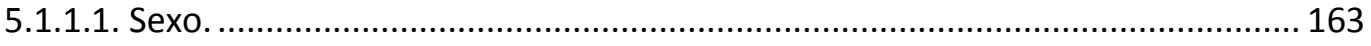

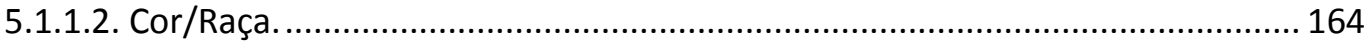


5.1.1.4. Socialização Organizacional. ............................................................................ 165

5.1.1.5. Função do Estado. .................................................................................... 166

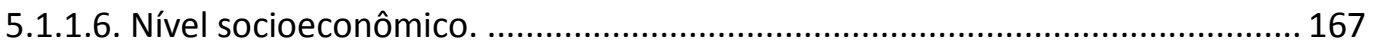

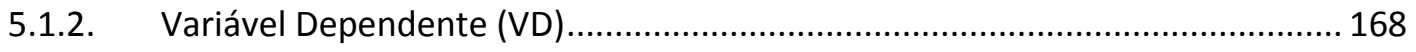

5.1.2.1. Coerência da variável dependente......................................................... 168

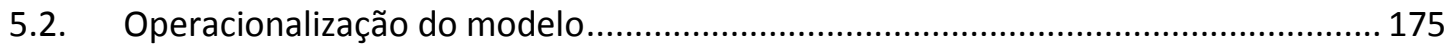

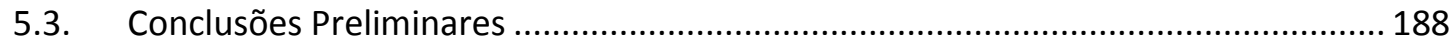

Capítulo 6 - O que disseram os nossos entrevistados ................................................ 190

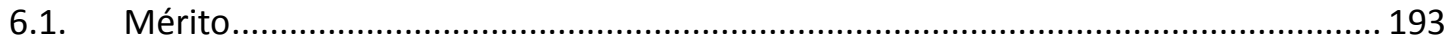

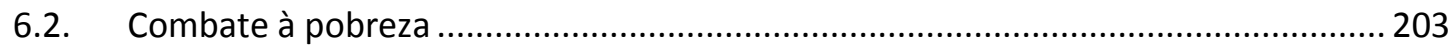

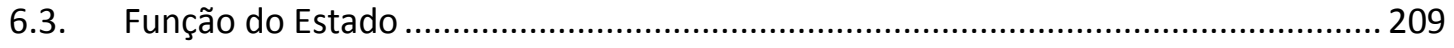

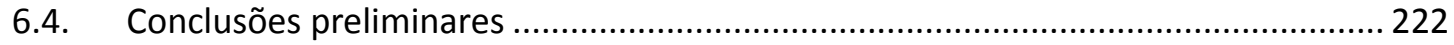

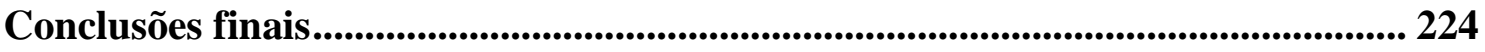

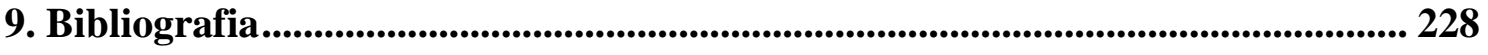

10. Anexos......................................................................................................................... 243

Anexo A .......................................................................................................................................... 243

Anexo B............................................................................................................................................... 264

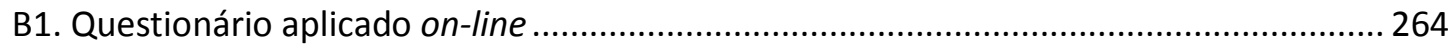

B2. Questões aplicadas na entrevista presencial ............................................................... 270

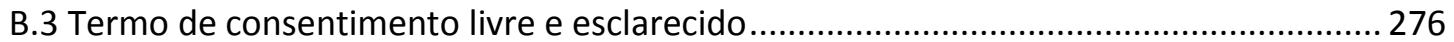

\section{TABELAS}

Tabela 1 - Quantitativo de vínculo de servidores das carreiras típicas da Administração Pública Federal - Dezembro/2012

Tabela 2 - Percentual de execução orçamentária dos programas do Orçamento da Igualdade Racial: 2008-2011 ..........................................................................65

Tabela 3 - Percentual de alcance das metas previstas dos programas do Orçamento

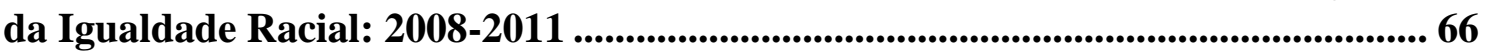

Tabela 4 - Orçamento autorizado de órgãos do sistema Minc: 2008-2011 (R\$) ..... 67

Tabela 5 - Orçamento liquidado de órgãos do sistema Minc: 2008-2011 (R\$) ....... 67

Tabela 6 - Percentual de execução orçamentária de órgãos do sistema Minc: 20082011 (R\$).

Tabela 7 - Orçamento autorizado dos órgãos de direitos da cidadania: 2008-2011 (R\$) 
Tabela 8 - Orçamento liquidado dos órgãos de direitos da cidadania: 2008-2011 (R\$)

Tabela 9 - Percentual da execução orçamentária dos órgãos de direitos da cidadania: 2008-2011.

Tabela 10 - Perfil dos servidores públicos ativos pertencentes às Carreiras Típicas de Estado selecionadas 102

Tabela 11 - Total de participantes das carreiras selecionadas 103

Tabela 12 - Percentual de participantes das carreiras selecionadas segundo cor/raça 104

Tabela 13 - Percentual de participantes das carreiras selecionadas por sexo 113

Tabela 14 - Percentual de participantes das carreiras selecionadas por faixa etária113

Tabela 15 - Quartil do nível socioeconômico 116

Tabela 16 - Percentual de servidores no exercício de DAS e participação em processos decisórios de políticas públicas.

Tabela 17 - Percentual de servidores no exercício de DAS (2007-2012) e participação em processos decisórios de políticas públicas.

Tabela 18 - Percentual das carreiras na participação de processos decisórios de políticas públicas.

Tabela 19 - Matriz de correlação entre as variáveis de propostas de políticas públicas para a população negra (PP_Negros) 172

Tabela 20 - Matriz de correlação entre as variáveis de propostas de políticas públicas de combate à pobreza (PP_Pobres)

Tabela 21 - Percentual explicado das variáveis independentes em relação às variáveis dependentes 178

Tabela 22 - Modelo de regressão para apoio a políticas de promoção da igualdade racial para negros

Tabela 23 - Cruzamento entre a função do Estado OrdemLeisObedecidas e políticas de promoção da igualdade racial $(\%)$ 180

Tabela 24 - Cruzamento entre a função do Estado CapacitadasReconhecidas e políticas de promoção da igualdade racial $(\%)$.

Tabela 25 - Cruzamento entre a função do Estado ProteçãoaTodos e políticas de promoção da igualdade racial $(\%)$

Tabela 26 - Cruzamento entre a função do Estado MercadoVidaSocial e políticas de promoção da igualdade racial $(\%)$ 183

Tabela 27 - Cruzamento entre a função do Estado PolíticasIgualdadeSocEconômica e políticas de promoção da igualdade racial $(\%)$

Tabela 28 - Cruzamento entre a função do Estado ProblemaPobresApoioEstado e políticas de promoção da igualdade racial $(\%)$ 
Tabela 29 - Cruzamento entre a função do Estado DemandasCidadãoDemocrático e políticas de promoção da igualdade racial $(\%)$

Tabela 30 - Cruzamento entre experiência em gestão e políticas de promoção da igualdade racial $(\%)$

Tabela 31 - Estatísticas descritivas de políticas públicas para negros e pobres ... 191

Tabela 32 - Percentual de pessoas que concordam ou não com propostas de políticas públicas para negros e pobres

Tabela 33 - Cruzamento entre as variáveis Negros_IESAcesso e Pobres_IEAcesso $(\%)$

Tabela 34 - Percepção dos servidores sobre as funções do Estado (\%)

Tabela A1 - Cruzamento das variáveis Negros_CrecheEscola e Pobres_CrecheEscola (\%)

Tabela A2 - Cruzamento entre as variáveis Negros_CursinhosVestibular e

Pobres_CursinhosVestibular (\%)

Tabela A3 - Cruzamento entre as variáveis Negros_IESAcesso e Pobres_IEAcesso (\%)

Tabela A4 - Cruzamento entre as variáveis Negros_UnidadesSaúde e Pobres_UnidadesSaúde (\%)

Tabela A5 - Cruzamento entre as variáveis Negros_FábricasÁreas e

Pobres_FábricaÁreas (\%)

Tabela A6 - Cruzamento entre as variáveis Negros_ConcursoPúblico e

Pobres_ConcursoPúblico (\%)

Tabela A7 - Coeficientes estimados da influência de variáveis em relação às políticas de promoção da igualdade racial para população negra de acordo com diferentes modelos de Regressão Múltipla Linear. 246

Tabela A8 - Número de carreiras por ocupação principal do pai 247

Tabela A9 - Número de carreiras por ocupação principal da mãe 250

Tabela A10 - Número de carreiras por escolaridade do pai.................................. 252

Tabela A11 - Número de carreiras por escolaridade da mãe 252

Tabela A12 - Metas físicas previstas e alcançadas dos programas do Orçamento da Igualdade Racial: 2008-2011 (unidade). 253

Tabela A13 - Evolução de indicadores para igualdade racial 254

Tabela A14 - Evolução de indicadores para igualdade racial: amplitude dos indicadores entre negros e brancos e entre negros e Brasil. 256

Tabela A15 - Evolução de indicadores para igualdade racial: amplitude dos indicadores intragrupos - 2004 e 2011 258 


\section{GRÁFICOS}

Gráfico 1 - Comparação entre brancos e negros da taxa de analfabetismo em 2004 e 2011

Gráfico 2 - Comparação entre brancos e negros da taxa de frequência bruta na educação superior em 2004 e 2011

Gráfico 3 - Comparação entre brancos e negros em relação ao rendimento médio de todos os trabalhos em 2004 e 2011 (R\$)

Gráfico 4 - Comparação entre brancos e negros em relação ao percentual de pessoas que vivem em domicílios com escoadouro do banheiro ou sanitário por rede coletora ou fossa séptica em 2004 e 2011

Gráfico 5 - Comparação entre brancos e negros em relação ao percentual de pessoas que vivem em domicílios com máquina de lavar roupas em 2004 e 2011 76

Gráfico 6 - Comparação entre brancos e negros em relação à taxa de homicídios de jovens do sexo masculino de 15 a 29 anos por 100 mil habitantes em 2004 e 201177

Gráfico 7 - Comparação entre brancos e negros em relação ao percentual das populações de 18 a 24 anos que não estudam, não trabalham, nem estão procurando emprego em 2004 e 2011

Gráfico 8 - Comparação entre brancos e negros em relação ao percentual das populações de 25 a 29 anos que não estudam, não trabalham, nem estão procurando emprego em 2004 e 2011 .

Gráfico 9 - Nível socioeconômico 168

Gráfico 10 - Dimensionamento (Scree plot) das variáveis. 173

\section{QUADROS}

Quadro 1 - Características heterogêneas e homogêneas das carreiras pesquisadas85

Quadro 2 - Perfil sociodemográfico dos dirigentes de políticas de promoção da igualdade racial entrevistados -2014 ........................................................................... 119

Quadro 3 - Síntese das variáveis que representam as propostas de políticas públicas para a população negra (PP_Negros) 170

Quadro 4- Síntese das variáveis que representam as propostas de políticas públicas para o combate à pobreza (PP_Pobres) ............................................................................ 171

Quadro 5 - Operacionalização das variáveis dependentes e independentes ......... 176

Quadro A1 - Perfil sociodemográfico dos servidores das carreiras entrevistados 260 


\section{FIGURAS}

Figura 1 - Sistematização das políticas de promoção da igualdade racial .............. 33

Figura 2 - Fluxo da atuação no processo de formulação de políticas públicas .... 100

Figura 3 - Fluxo da atuação no processo de implementação de políticas públicas101

Figura 4 - Modelo de análise para representação ativa......................................... 154

Figura 5 - Modelo da teoria da burocracia representativa ................................... 155

Figura 6 - Representação de um modelo fatorial................................................... 169

Figura 7 - Modelo proposto ....................................................................................... 177 


\section{Introdução}

Com a redemocratização do país, a impossibilidade de se conter as reivindicações sociais dos negros brasileiros nos estreitos parâmetros da ideia freyreana de "democracia racial" fica de todo evidente. A nação brasileira, constituída como mestiça e sincrética, já não precisava reivindicar uma origem "não tipicamente ocidental". Ao contrário, as classes e grupos sociais farão dos direitos civis, individuais e universais o principal objetivo das lutas sociais.

Antônio Sérgio Alfredo GUIMARÃES (2002a:167)

O processo de formulação, implementação e avaliação das políticas públicas impacta a vida de uma população. Os agentes desse processo são múltiplos, envolvem desde os servidores públicos - políticos e técnicos - e todos os segmentos sociais que constituem mecanismos operacionais, políticos e gerenciais para a tomada de decisão de políticas públicas. Uma das questões deste estudo é se aqueles que operacionalizam o Estado conhecem e entendem a população a quem servem. Segundo dados do Censo de 2010, 50,74\% da população brasileira são negros - aqui entendido como pardos e pretos. Isso significa dizer que a população negra é potencialmente quem mais poderia se beneficiar das políticas públicas do Estado. Como explicar que os negros ainda vivam uma condição de desigualdade social? Essa desigualdade reflete a necessidade da intervenção estatal para elevar esse conjunto da população à condição de igualdade exercida pelos não negros na esfera socioeconômica.

Nesse contexto, as políticas de promoção da igualdade racial podem ser a chave para democratizar os recursos públicos e prover oportunidades iguais a populações em desvantagens socioeconômicas (LEITE; SOUZA, 2010; SILVEIRA; SANTOS, 2010; THEODORO et al, 2008). Essas políticas, ainda, são incipientes no espaço público e carecem de condições para elevá-las a um grau de efetividade satisfatório.

Entretanto, as políticas públicas de promoção da igualdade racial têm uma baixa capacidade técnica e institucional. Técnica, pois as ações ficam aquém de seus objetivos quando implementadas; e a bem da verdade as políticas de promoção da igualdade racial por serem dotadas de baixos recursos não geram impactos de grande escala. Do ponto de vista formal e jurídico, temos a institucionalidade dessas políticas públicas, entretanto elas não 
constituem ainda um valor englobante à estrutura do Estado. Ou seja, a prática cotidiana da administração pública empurra as políticas de promoção da igualdade racial para o vazio das normas que não têm patrocínio de uma autoridade política superior. Essa baixa efetividade é explorada por Theodoro (2008), ao analisar o caráter residual das políticas de combate à desigualdade racial do programa "Gestão da Política de Igualdade Racial", dotado de R \$ 20 milhões em 2005. Tratava-se, à época, do principal programa com o objetivo de reduzir as desigualdades raciais. $\mathrm{O}$ autor descreve que não houve envolvimento e sensibilização dos Ministérios e o que foi realizado foram ações a que denomina de residuais, como concessão de bolsas de estudos, treinamento de gestores e apoio a iniciativas municipais de igualdade racial. Ainda que a existência dessas ações possa incutir a sensação de que há avanços se compararmos a determinados períodos históricos, elas demonstram a lacuna da visão estratégica do Estado para o enfrentamento da questão racial. Ou seja, a não efetividade das políticas de promoção da igualdade racial para a população negra é um reflexo do processo lento de sua formulação ou da sua quase inoperância, quando aprovada a sua implementação, pela falta de recursos físicos, orçamentários, financeiros e de apoio técnico e político.

Estamos partindo do pressuposto de que a decisão de realizar determinada política pública não é baseada apenas em análises técnicas e políticas originárias de programas de governo, mas também na percepção individual e na visão de mundo daqueles que fazem parte do processo de tomada de decisão. De um ponto de vista sociológico, os indivíduos que pertencem a determinados grupos podem ser portadores das mesmas percepções sobre problemas sociais e podem exercer práticas semelhantes em um mesmo espaço social; então, é possível que esses indivíduos tenham a mesma atitude e comportamento frente a situações sociais semelhantes.

É importante frisarmos que no processo de formulação, implementação e avaliação de políticas públicas não estamos ignorando o papel e a grande influência dos agentes políticos, dos conselhos deliberativos e consultivos existentes na estrutura do governo, assim como dos grupos de interesses da sociedade civil, pois esses atores pressionam o Executivo e o Legislativo para o desenho e para a implementação de políticas públicas de seu interesse. Só que a ênfase nos servidores efetivos não é equivocada. Lima e Cheibub (1996), ao analisarem as dimensões da democracia na visão da elite brasileira, apresentam a percepção 
de cada setor da elite quanto à influência política que diversos grupos exercem no país. A elite brasileira, identificada naquele estudo, era composta por congressistas, administradores públicos, empresários e sindicalistas. Segundo Lima e Cheibub (1996), há um consenso sobre a alta influência política exercida pela mídia. Os técnicos do governo, na opinião dos setores da elite pesquisada, formam um grupo de influência moderada. Assim, é legítimo considerarmos que os servidores públicos fazem parte do processo de decisão das políticas públicas e, no caso da pesquisa aqui em questão, a falta de apoio técnico para a formulação e implementação das políticas de promoção da igualdade racial pode afetar os resultados dessas políticas.

Assim, o caminho adotado para entendermos os motivos que fazem com que as políticas de promoção da igualdade racial tenham uma baixa capacidade técnica e institucional é compreendermos como se posicionam alguns servidores que constituem a alta burocracia em relação a proposições e implementações dessas políticas. Para isso, algumas questões nos guiaram:

1. Qual é a natureza das políticas de promoção da igualdade racial?

2. Qual é o apoio desse grupo de servidores às políticas de promoção da igualdade racial? A alta burocracia técnica com quem trabalhamos neste estudo concorda com propostas de políticas para a população negra? Quais são as razões de concordar ou discordar e as suas relações com o pensamento social?

3. Os servidores que participaram deste estudo consideram-se importante nos processos decisórios?

4. O Estado possui uma alta burocracia técnica capaz de pensar políticas para a população negra? A alta burocracia técnica de que trata este trabalho pode ser considerada uma burocracia representativa ativa? Ou ela pode ser considerada uma burocracia representativa passiva? Ou pode ser considerada sob esses dois aspectos - representativa ativa e passiva?

A metodologia de aferição do objetivo deste estudo é identificar como algumas carreiras burocráticas se posicionam em relação a propostas de políticas públicas de promoção da igualdade racial. Os servidores selecionados para este estudo pertencem às Carreiras Típicas 
de Estado como: Advogado da União, Analista de Planejamento e Orçamento, Especialista em Políticas Públicas e Gestão Governamental, Técnico de Pesquisa e Planejamento do Instituto de Pesquisa Econômica Aplicada-Ipea e Procurador Federal.

A princípio, tínhamos como interesse categorizar esse grupo de carreiras como uma elite do serviço público, mas mudamos de curso porque numa análise sobre o processo de instituição de uma elite não encontramos elementos suficientes para trazer à tona esse debate.

Primeiro, não há uma estratégia das instituições responsáveis por essas carreiras de criar um ethos específico, tal qual existe na diplomacia, conforme observamos nos relatos sobre o processo de socialização da carreira de diplomata realizados por Moura (2007). Muito menos existe um rito de passagem como consta em Bourdieu (1989), ao referenciar Arnold van Gennep (BOURDIEU,1989:140)ํㅗ․ Bourdieu (1989) explora o rito de passagem como um processo de transformação que ocorre nas escolas de elite, através de operações mágicas de separação e agregação de semelhantes que tendem a produzir uma elite não só distinta, separada, mas também que se reconhece como digna de tal posição social. Apesar de alguns membros das carreiras de nosso estudo fazerem alusão à dificuldade do concurso e do curso de formação, assim como da formação pré-concurso, isso nada diz sobre a construção de um ethos. O que nivela essas pessoas é o concurso, que atesta que a partir daquele momento todos têm o mesmo conhecimento; e as instituições que os supervisionam estão interessadas muito mais em formar, qualificar minimamente as pessoas para tocar a máquina administrativa e não em construir uma cultura dentro dessas carreiras. $\mathrm{O}$ conhecimento e o reconhecimento que existe parte mais dos próprios servidores do que das instituições que os supervisionam.

Um segundo aspecto é que os membros dessas carreiras não se veem como uma elite do serviço público, uma vez que $70 \%$ dos respondentes do questionário afirmaram que não se consideravam membros da elite do serviço público brasileiro. $\mathrm{O}$ fato de não possuírem uma autopercepção sobre a sua condição no espaço público nos distancia do conceito de elite dentro do que propõem alguns teóricos sobre elite. Aron (2008) faz uma leitura sobre Pareto,

\footnotetext{
${ }^{1}$ Arnold van Gennep foi um antropólogo francês (1873-1957), e seus estudos tratam do rito de passagem em várias culturas.
} 
afirmando que elite é um pequeno número de pessoas que chegou a um nível elevado da hierarquia profissional. Já Mosca (1939) defende que elite representa, de alguma maneira, os interesses e os desígnios de grupos importantes e influentes na sociedade. A composição dessa elite, para Mosca (1939), inclui também funcionários públicos.

Por essas lacunas simbólicas, optamos conceitualmente em denominar os participantes deste trabalho como alta burocracia técnica. A administração pública tem dois mundos burocráticos, um técnico e outro político. No Poder Executivo da Administração Direta e Indireta, as chamadas Carreiras Típicas de Estado formam a alta burocracia do serviço público. Ela é recrutada por meio de concurso público, possui atuação no nível técnico e é profissionalizada em termos de carreira. Em linha oposta, a alta burocracia política é escolhida por uma autoridade superior cuja dinâmica de seleção se baseia em critérios que vão desde a relações pessoais, profissionais e até algum tipo de mérito como a representação social e política de certos segmentos.

No aspecto geral, entendemos que os servidores públicos têm algumas vantagens comparativas vis-à-vis aos trabalhadores do setor privado. A remuneração e a estabilidade são vantagens que o serviço público oferece e que têm aumentado o interesse pelo exercício da função pública no Brasil. Essa caracterização é possível de ser averiguada quando comparamos o crescimento da remuneração no serviço público em relação ao serviço privado, sobretudo no nível federal, conforme esclarecem Carvalho (2011) e Souza e Medeiros (2013) ao tratarem das remunerações no setor público. Acompanhamos o mesmo entendimento que Matias-Pereira (2004) quando afirma que as classes A e B ${ }^{2}$ brasileira deixaram de ter o serviço público como uma opção secundária de carreira para integrar maciçamente os seus quadros a partir da década de 1990.

Dentro do conjunto das Carreiras Típicas de Estado, selecionamos os seguintes grupos para este estudo:

\footnotetext{
${ }^{2}$ Matias-Pereira (2004) entende como classe A pessoas com renda familiar acima de 20 salários mínimos; classe B, entre 10 a 20 salários mínimos.
} 
Tabela 1 - Quantitativo de vínculo de servidores das carreiras típicas da Administração Pública Federal - Dezembro/2012

\begin{tabular}{llc}
\hline Carreira & \multicolumn{1}{c}{ Cargo } & $\begin{array}{c}\text { Quantitativo Total } \\
\text { (Ativos) }\end{array}$ \\
$\begin{array}{l}\text { Carreira de Planejamento e Orçamento } \\
\text { Carreira de Especialista em Políticas }\end{array}$ & $\begin{array}{c}\text { Analista de Planejamento e Orçamento } \\
\text { Especialista em Políticas Públicas e }\end{array}$ & 588 \\
$\begin{array}{l}\text { Públicas e Gestão Governamental } \\
\text { Carreira de Planejamento e Pesquisa da }\end{array}$ & $\begin{array}{l}\text { Gestão Governamental } \\
\text { Técnico de Planejamento e Pesquisa }\end{array}$ & \multirow{2}{*}{246} \\
Fundação Instituto de Pesquisa & (Nível Superior) & \\
Econômica Aplicada-Ipea & Advogado da União* & 1.662 \\
Carreira da Área Jurídica & Procurador Federal & 4.046 \\
Carreira da Área Jurídica & & $\mathbf{7 . 5 8 5}$ \\
Total & &
\end{tabular}

* Advogado da União - lotado na Advocacia Geral da União

Fonte: Boletim Estatístico de Pessoal/MP - vol. 17, n 200, Dez/2012

O maior motivo para escolhermos essas carreiras (Tabela 1) foi o fato de elas atuarem no ciclo de políticas públicas. Segundo a lei de criação e outros instrumentos jurídicos, essas carreiras deveriam atuar no processo de elaboração, implementação e avaliação de políticas públicas quer seja nas funções de gerência estratégica e operacional ou no assessoramento direto aos tomadores de decisão. Além desses aspectos, pesou também o caráter perene da função exercida por esses servidores em relação ao corpo político que atua no Estado.

Tivemos a curiosidade em saber o perfil dos servidores que compõem tais carreiras. Esse perfil reflete o conjunto da sociedade brasileira? Essa reflexão deu subsídio para explorarmos as opiniões desses servidores frente a políticas que favoreçam a população negra sob a teoria da burocracia representativa (representative bureaucracy), que teve como seus precursores Kingsley (1944a) e Mosher (1968). Essa teoria se concentra em dois polos: primeiro, a análise sobre a origem social dos servidores públicos denominada de representação passiva (ou sociológica); segundo, a investigação da representação ativa (ou responsabilidade), em que se espera que o servidor público incline-se favoravelmente aos interesses e aos desejos daqueles que representa - que pode ser a população em geral ou algum segmento dessa população.

Estudos na área de representação social, apesar de um grande acúmulo de dados que vem desde a década de 1950, ainda não tiveram conclusões definitivas sobre a relação de atributos pessoais e ações sociais como o que se propõe a teoria da burocracia representativa. Isso levou ao desinteresse por este tema na academia, com um vácuo na produção de conhecimento ao longo do século passado e início do século XXI. Ogmundson (2005) sugere 
reabrir a discussão dentro do contexto canadense, trabalhando com o conceito de elite ou mais precisamente características sociais de elites. $\mathrm{O}$ autor identifica que houve um declínio de interesse pela academia em estudar características sociais e sua influência comportamental. Um dos fatores que o autor imputa é a crença de que características sociais de uma elite não influenciam atitudes ou comportamentos de grupos poderosos de uma maneira sistemática. Ogmundson (2005) acredita que num mundo globalizado valeria a pena analisar o grau de características sociais, como gênero, etnia, orientação sexual na elite canadense e examinar se há um impacto sistemático nas suas decisões.

Infelizmente, não encontramos referência de estudos nacionais que ressoassem a teoria da burocracia representativa na análise da burocracia pública brasileira. A literatura acadêmica brasileira é marcada pela ausência de estudos sobre a burocracia na democracia contemporânea; são quase inexistentes os estudos sobre a função da burocracia pública no jogo democrático. Loureiro, Abrucio e Pacheco (2010a) afirmam que as pesquisas brasileiras privilegiam estudos de casos de instituições governamentais com enfoque sobre a relação do Estado e sociedade, ao contrário da literatura dos Estados Unidos e mais recentemente da Europa, que têm como problemática de estudo o burocrata.

Mas, em relação ao objeto deste estudo, encontramos dados de uma pesquisa de 2006 conduzida por Osório (2006) que trazem um retrato das desigualdades raciais e de gênero no serviço público. Essa pesquisa aponta que dos 580 mil servidores do Poder Executivo da Administração Direta e Indireta na época, $63 \%$ eram brancos, 35\%, negros e 2\%, amarelos ou indígenas. Nesse conjunto de servidores, $45 \%$ eram mulheres e $55 \%$, homens. Com dados de 2003, a pesquisa faz uma comparação entre esse conjunto de servidores com a população brasileira em geral e com a População Economicamente Ativa-PEA, na faixa etária de 20 a 69 anos, em que as mulheres e negros representavam quase metade da PEA, $43 \%$ e $45 \%$ respectivamente ${ }^{3}$, e em relação à população em geral, $52 \%$ e $44 \%$ respectivamente.

O que a pesquisa conduzida por Osório (2006) procura demonstrar é que no serviço público as desigualdades raciais e de gênero são também reproduzidas. Podemos encontrar um perfil

\footnotetext{
${ }^{3}$ A PEA apresenta dados de pessoas, na mesma faixa etária - 20 a 69 anos, que estavam trabalhando ou procurando um trabalho.
} 
diferente quando se trata dos servidores públicos que gerenciam as políticas de promoção da igualdade racial no Brasil? Oliveira, D.D. (2009) ao descrever o perfil desse grupo num levantamento realizado em 2005, revela que há quase um equilíbrio de gênero entre esses gestores, $51 \%$ são do sexo masculino e cerca de $49 \%$ são do sexo feminino. Na categoria racial, $87 \%$ são negros. $\mathrm{O}$ autor ressalta que o aspecto negativo é que a maioria desses gestores exercem função comissionada ou são requisitados, o que pode acarretar descontinuidade dessas políticas no médio prazo.

A partir da segunda metade do século passado, o conceito de raça como categoria biológica que determinava o comportamento moral, intelectual e cultural foi desconstruído por diversas pesquisas científicas. Entretanto, raça como uma categoria sociológica tem sido usada para fundamentar discussões e propostas de intervenção socioeconômica para a população negra. Para seus propositores, o racismo brasileiro materializa-se em indicadores de desigualdades educacionais, sociais e econômicas. Recentemente, no Brasil, vem sendo incorporada a variável cor e/ou raça na formulação e implementação das políticas públicas pelo Estado. Um exemplo mais visível, a despeito de causar ainda grande divergência entre alguns setores, são as políticas de ações afirmativas para ingresso no ensino superior.

Podemos citar, ainda, outros exemplos, de um conjunto de políticas públicas voltadas à promoção da igualdade racial e à valorização da identidade negra: Política Nacional de Saúde Integral da População Negra, Programa Brasil Quilombola, Plano Setorial de Qualificação (Planseq) Trabalho Doméstico Cidadão, Plano Nacional de Implantação da Lei n 10.639 (que altera a Lei de Diretrizes e Bases da Educação-LDB e torna obrigatório o ensino de história e cultura da África e das populações negras brasileiras nas escolas de ensino fundamental e médio de todo o país), Programa Institucional de Bolsas de Iniciação Científica (PIBIC-Ações Afirmativas), Estatuto da Igualdade Racial.

O problema desta pesquisa é entender a baixa capacidade técnica e institucional das políticas de promoção da igualdade racial. A falta de apoio técnico e político reflete a operacionalidade dessas políticas públicas. A formulação das políticas de promoção da igualdade racial é lenta, pois intervém em estruturas arraigadas na nossa sociedade. Na fase 
de implementação, a inoperância dessas políticas se faz sentir pela falta de recursos físicos, orçamentários, financeiros e servidores qualificados.

Neste estudo, a maioria dos entrevistados afirmava o seu apoio a políticas de promoção da igualdade racial, entretanto, não havia a mesma aprovação quando questões específicas eram apresentadas sobre o que seriam as políticas para a população negra. Ou seja, os entrevistados apoiavam e depois quando confrontados com questões supostamente de ordem prática, eles negavam o que tinham afirmado anteriormente, o que nos levou a explorar neste estudo as razões de discordarem dos propósitos das políticas de promoção da igualdade racial para a população negra.

Buscamos entender, portanto, se o Estado ao elaborar, implementar e avaliar políticas de inclusão socioeconômica da população negra conta com uma rede de apoio dentro do seu quadro efetivo e técnico. Dessa forma, acreditamos que este estudo poderá colaborar para a construção de uma literatura sobre políticas de promoção da igualdade racial no Brasil. Esse é um objeto de estudo que identificamos como um espaço vazio de explicação para o qual nos propomos a colaborar e descobrir aspectos ainda não problematizados.

Como se sabe, algumas concepções ideológicas norteiam a formação e os obstáculos para os avanços das políticas de promoção da igualdade racial. Mencionaremos brevemente essas concepções, mas não trabalharemos por este caminho, pois acreditamos que os fundamentos apresentados a seguir são incontestáveis no imaginário da população brasileira. Conceber o Brasil como um país estruturado nas teses da democracia racial e da mistura racial harmônica e cordial é uma ideia hegemônica difundida na sociedade brasileira desde o início do século $\mathrm{XX}$.

Entendemos que a ideia de democracia racial é a base da nação brasileira. Guimarães (2002b) afirma que no início do século XX essa ideologia corria o mundo, o Brasil era tido como o paraíso racial, um exemplo para as outras nações de democracia racial:

\footnotetext{
A ideia de que o Brasil era uma sociedade sem "linha de cor", ou seja, uma sociedade sem barreiras legais que impedissem a ascensão social de pessoas de cor a cargos oficiais ou a posições de riqueza ou prestígio, era já uma ideia bastante difundida no mundo, principalmente nos Estados Unidos e na
} 
Europa, bem antes do nascimento da sociologia. Tal ideia, no Brasil moderno, deu lugar à construção mítica de uma sociedade sem preconceitos e discriminações raciais (Guimarães, 2002b:2).

A ideia de democracia racial vem sendo denunciada como um mito desde o revisionismo das relações raciais realizado pela Escola Paulista de Sociologia na década de 1950. Viotti da Costa (1985) discute o mito da democracia racial ao enumerar as funções da constituição de um mito por toda a sociedade. O mito pode ajudar a reduzir um conflito social, mas também obscurecer a percepção dos indivíduos sobre a sua própria realidade. Isso ao mesmo tempo em que o mito e a realidade estão inter-relacionados. Guimarães (2006) sustenta que alguns antropólogos (o autor cita FRY, 1995; MAGGIE, 1996; SCHWARCZ; MICELI, 1999), ao analisar o ataque do movimento social negro ao conceito de democracia racial, defenderam que o mito é um conjunto de valores que têm efeitos concretos na vida prática das pessoas, muito antes de ser uma falsa consciência.

No nosso entender o mito da democracia racial levou ao estabelecimento de uma harmonia social orgânica, auxiliou a estabilidade social do país, entretanto o mesmo não se pode afirmar sobre a vida prática dos negros brasileiros. Eles continuam enfrentando o racismo do cotidiano expresso na sua invisibilidade socioeconômica.

Para Viotti da Costa (1985) alguns entendem a ideologia da democracia racial como um mero reflexo da realidade. As mudanças na estrutura social e econômica na sociedade brasileira, como a industrialização, urbanização, desenvolvimento capitalista, ampliaram a competição e agravaram os conflitos sociais levando os brasileiros a terem atitudes racistas. Uma segunda forma de ver a democracia racial é que ela seria uma distorção do padrão real das relações raciais no Brasil. Uma conspiração de envergadura maquiavélica da classe dominante como forma de manipulação de instrumentos usados pela classe alta branca. Um terceiro entendimento é que o conceito de democracia racial tem suas origens na ideologia racial brasileira inspirado em eventos ocorridos na Europa e nos Estados Unidos.

Esse último aspecto é exaustivamente discutido por Skidmore (2012). O autor entende que a elite brasileira do final do século XIX até 1930 defendia teorias racistas baseadas na hierarquia de raças e que o Brasil deveria superar o seu futuro, que era incerto graças ao componente negro da sua população. As estratégias discutidas pela elite nacional para elevar o país a níveis de desenvolvimento respeitáveis eram, primeiramente, pelo estímulo à 
imigração europeia que levaria ao branqueamento da população brasileira; segundo, a defesa e a glamorização da miscigenação; e, terceiro, a degradação de vida da população negra, que, consequentemente, provocaria sua redução numérica.

Viotti da Costa (1985) reconhece que não se pode afirmar que havia uma intenção proposital da elite brasileira em criar e difundir o mito da democracia racial prevendo os seus efeitos e suas funções. A não intencionalidade é analisada por Althusser (1980), ao alertar que, se o sujeito não faz aquilo em que acredita, é porque faz outra coisa, tem ideias diferentes das que proclama e age segundo essas outras ideias, "ninguém é mau voluntariamente" (ALTHUSSER, 1980:87).

Viotti da Costa (1985) admite que, fundamentalmente, o mito da democracia racial mascara a natureza das relações raciais brasileiras e disfarça o preconceito e a discriminação racial. A autora defende que o mito da democracia racial beneficiou brancos e negros, ampliando para estes últimos a dificuldade em desenvolver o pertencimento de grupo.

Guimarães (2006) compartilha dessa mesma posição, ao entender que se pode analisar democracia racial não apenas como mito, mas como cooperação, consentimento ou compromisso político ao longo do último século:

\footnotetext{
Entendo por "consentimento", à maneira de Przeworski (1985, p. 146), o comportamento coletivo em que os "negros agem esperando melhorar sua condição material de vida seguindo as regras sociais dadas. "Cooperação consiste em utilizar-se de estratégias e ameaças conhecidas pelo oponente no curso da negociação". No compromisso, o consentimento das organizações negras à democracia representativa é possível em troca da perspectiva de integração social e de melhoria material de vida (Guimarães, 2006:270).
}

A despeito de concordarmos que não temos evidências empíricas para afirmar que a ideologia da democracia racial foi propositalmente construída e disseminada, ela é o fundamento utilizado massivamente para defender que no Brasil a desigualdade é de caráter social e não racial. A defesa dessa tese se dá por muitos autores pela evidência de que o país é constituído pela união de três raças - branco, negro e índio -, e que a miscigenação racial amalgamou a harmonia social. Outra evidência é a ausência de conflito racial e de racismo institucionalizado a exemplo, sobretudo, dos Estados Unidos da América, que tiveram uma 
doutrina racista para justificar a limitação dos direitos dos negros (GUIMARÃES, 2002b; VIOTTI DA COSTA, 1985).

Essa é uma ideologia que se naturalizou nas relações sociais brasileiras e persiste em diversos espaços, ainda que Guimarães (2006) afirme que o apelo à democracia racial latinoamericana foi retirado devido ao conceito de democracia nos dias de hoje, fundamentada em direitos civis, sociais e políticos para todos. No Estado, a crença, porém, de uma democracia racial como mito restringe ações governamentais que visam à redução e à erradicação da desigualdade racial no Brasil, pois os servidores que operam o sistema público estatal estão impregnados dessas mesmas ideias que influenciam os seus comportamentos. Acreditam que não há um problema de natureza racial no país; portanto, não há o que combater.

As concepções de Estado também são um empecilho para o avanço das políticas de promoção da igualdade racial. Uma delas é a ideia de que não cabe ao Estado desenvolver políticas focalizadas em grupos específicos, pois deveria se trabalhar a totalidade para o alcance do bem comum. Essa filosofia leva a um enrijecimento das estruturas que estão postas para defender e articular ações em prol da igualdade racial, assim como à interpretação de que cabe ao Estado a manutenção de uma determinada ordem contratada e de que a sua intervenção na esfera pública deve ser mínima. Essas concepções dificultam a implementação de políticas de promoção da igualdade racial, redundando na sua baixa efetividade, porque elas são concebidas como políticas focalizadas que objetivam alterar a estrutura social brasileira.

A concepção do papel de Estado e das relações raciais no Brasil que se manifesta nos comportamentos da burocracia foi construída nos espaços de múltiplas relações sociais. $\mathrm{O}$ Estado, por meio de sua burocracia, tende a reproduzir as relações sociais hegemônicas.

Não há estudos significativos e sistemáticos sobre a formulação e implementação de políticas de promoção da igualdade racial, sobretudo no Brasil. Visto que são políticas que entraram na agenda do Estado recentemente e que, ainda, precisam se legitimar técnica e institucionalmente na Administração Pública. Um caso mais emblemático são as ações 
afirmativas nas instituições de ensino superior, que carecem, ainda, de maturidade para analisar os seus efeitos sociais e econômicos.

Este trabalho está estruturado em seis capítulos, além desta introdução e das conclusões finais. O Primeiro Capítulo é predominantemente teórico, em que abordamos conceitos de políticas públicas e políticas de promoção da igualdade racial. Mais ainda, apresentamos a atuação do movimento social negro na reivindicação de políticas públicas para a população negra por meio de relatos de suas lideranças e como se deu o processo que desembocou na instituição pelo Estado de uma agenda de promoção da igualdade racial. Em seguida, nos Capítulos Segundo e Terceiro descrevemos respectivamente os procedimentos metodológicos e os sujeitos que participaram desta pesquisa. O Quarto Capítulo é dedicado a uma discussão teórica e empírica sobre a atuação da burocracia no Estado, a sua autonomia e a sua importância em processos decisórios de políticas públicas. Por fim, sobre os fundamentos da teoria da burocracia representativa, apresentamos dados quantitativos, em bases de procedimentos estatísticos, e qualitativos para discutir a percepção dos burocratas sobre propostas de políticas de promoção da igualdade racial, focando a nossa análise nos conceitos de representação passiva e representação ativa daquela teoria. Essas discussões são tratadas nos Capítulos Quinto e Sexto.

Por fim, propomos analisar a percepção e o apoio daqueles que fazem parte da estrutura burocrática do Estado. Sabemos que de um modo geral os argumentos contrários a ações voltadas à população negra recaem sobre meritocracia; princípio constitucional de igualdade de todos; dificuldade em demarcar quem é negro ou não negro no Brasil; priorização de políticas universais frente às políticas focalizadas; existência de desigualdade social e não racial (FRY, 2007; KAMEL, 2006; MAGGIE; FRY, 2004; MAGGIE, 2009). Por outro lado, aqueles que são favoráveis à implementação de políticas de promoção da igualdade racial fazem um contraponto se valendo dos efeitos do passado de escravidão da população negra; do princípio de igualdade reversa, ou seja, tratar de forma desigual aqueles que não são iguais; instituição de uma elite negra como forma de consolidação de uma identidade; da não existência de meritocracia no Brasil, pois é um país desigual desde a sua origem (BERNARDINO-COSTA, 2002; ROCHA-PINTO, 2006; SANTOS, 2009). 
Essas constatações são úteis para nos guiar sobre as percepções dos sujeitos da nossa pesquisa, pois são atores sociais atuando na estrutura do Estado. Não apenas à distância, mas presentes diretamente no debate atual que existe sobre as demandas da população para a formação de uma agenda própria no espaço governamental. 


\title{
Capítulo 1 - Políticas públicas e políticas de promoção da igualdade racial
}

O importante é procurar estar atento aos processos que estão ocorrendo dentro dessa sociedade, não só em relação ao negro, ou em relação à mulher. Você tem que estar atento a esse processo global e atuar no interior dele para poder efetivamente desenvolver estratégias de luta. ...só na prática é que se vai percebendo e construindo a identidade, porque o que está colocado em questão, também, é justamente uma identidade a ser construída, reconstruída, desconstruída, num processo dialético realmente muito rico.

Lélia GONZALES

\author{
Será que você não viu \\ Não entendeu o meu toque \\ No coração da América eu sou o jazz, \\ Sou o rock \\ Eu sou parte de você \\ Mesmo que você me negue \\ Na beleza do afoxé \\ Ou no balanço no reggae \\ Lazzo MATUMBI (Alegria da Cidade)
}

\begin{abstract}
O papel do Estado é de facilitar um pouco a execução de nossas políticas (políticas públicas que beneficiam a população negra, esclarecimento nosso)...mas o Estado não está aí para facilitar, é mais um local de disputa, de disputa de interesses. Não tenho grande ilusão de que nada pode ser feito se a gente não entrar no debate, entrar no conflito, entrar nos erros e nos acertos, na superação das questões...eu não tenho ilusão nenhuma em relação a isso. (Dirigente 5)
\end{abstract}

Nos últimos vinte anos o combate à desigualdade racial ganhou contornos de políticas públicas. Paulatinamente, no Brasil, veio se consolidando a discussão sobre os problemas fundamentais que alijam a população negra do desenvolvimento social e econômico do país. Isso muito se deveu à organização e à persistente denúncia do movimento social negro brasileiro e aos acordos internacionais de combate ao racismo e à discriminação racial assinados pelo Brasil. Essa mobilização pautou a agenda governamental com a temática racial. 
Uma das proposições mais expressivas no aparelho do Estado é a instituição de políticas de promoção da igualdade racial. Essas políticas objetivam diretamente erradicar e diminuir a condição de desigualdade social e econômica de grupos étnicos e raciais no Brasil, tendo como fim o combate ao racismo e à discriminação racial. $\mathrm{O}$ desenho e a execução dessas políticas ganharam visibilidade e, junto com esse campo de conhecimento, veio a problematização da efetividade de sua formulação e implementação nas dimensões das políticas públicas. As políticas de promoção da igualdade racial abrangem toda e qualquer pessoa em função da sua cor, raça, cultura e/ou origem étnica. Este trabalho, contudo, restringe o seu foco de análise às políticas públicas que beneficiam a população negra.

Políticas públicas são um conjunto de ações do Estado interligadas. São desempenhadas por diferentes policymakers (tomadores de decisão) para tratar de um problema ou de questões de interesse. Esse conceito tem como referência para a sua construção os seguintes autores: Howlett e Ramesh (2003); Lasswell (1984); Monteiro (1982).

Howlett e Ramesh (2003), ao tratarem sobre os ciclos das políticas públicas e seus subsistemas, trazem uma definição mais simples de políticas públicas ao considerar o seu propósito, afirmando que elas resultam da decisão tomada pelo governo. Apresentam a definição de políticas públicas de Dye (1972 apud HOWLETT; RAMESH, 2003) como alguma coisa que o governo decide fazer ou não fazer. Nessa definição, segundo Howlett e Ramesh (2003), não há decisões das empresas privadas, das organizações governamentais, grupos de interesse, indivíduos ou outro grupo social. Jenkins (1978 apud HOWLETT; RAMESH, 2003) conceitua políticas públicas como um conjunto inter-relacionado de decisões tomadas por um ator político ou grupo de atores levando em conta os seus resultados e os meios para alcançá-los. Anderson (1984 apud HOWLETT; RAMESH, 2003) afirma que políticas públicas são ações intencionais tomadas por um ator ou um conjunto de atores para tratar de um problema ou de questões de interesse.

Talvez a definição mais apropriada de política pública para este trabalho seja a cunhada por Laswell, um dos pais da área de políticas públicas na Ciência Política. Para Lasswell (1984), a política pública pode ser definida por quem ganha o quê, por quê, quando e como ganha. Entendemos, por essa definição, que o termo política pública é usado para estudar a 
influência e as pessoas influentes. As pessoas influentes, segundo o autor, são aquelas que se apossam da maior parte do que é apropriável como deferência (respeito), renda e segurança. Monteiro (1982) defende que política pública é um conjunto de ações interligadas que são desempenhadas por diferentes policymakers (tomadores de decisão), em diversos estágios do processo decisório.

O objetivo deste capítulo é analisar a efetividade das políticas de promoção da igualdade racial e a sua capacidade técnica e institucional. A resposta a esse desafio não é fácil e não é consensual. Os resultados dessas políticas dependem do apoio técnico e político para a sua formulação e a sua execução; do desatar de nós sobre o significado de políticas transversais voltadas para as minorias sociais. E, ainda, de desconstruir a naturalização da desigualdade racial no funcionamento das instituições públicas ao prestar serviços, ofertar benefícios e oportunidades de maneira diferenciada.

Para realizar essa análise, procuramos entender o papel do Estado e dos movimentos sociais como uma linha histórica de discussão e de ações para a implantação na agenda governamental das políticas de promoção da igualdade racial. Discutimos a natureza das políticas de promoção da igualdade racial sob as categorias de políticas compensatórias, de reconhecimento e de redistribuição. Assim como, tentamos exemplificar a baixa capacidade técnica e institucional por meio da análise de dados de sistemas de gestão e de seus instrumentos operacionais.

\subsection{Políticas de promoção da igualdade racial e o protagonismo do movimento social negro}

Tomamos como conceito que políticas de promoção da igualdade racial são políticas transversais nas funções do Estado, cujo objetivo é a redução e erradicação das desigualdades social e racial como forma de combate ao racismo. O diagrama abaixo nos coloca uma operação de como as políticas de promoção da igualdade racial têm sido discutidas e implementadas atualmente (Figura 1). 


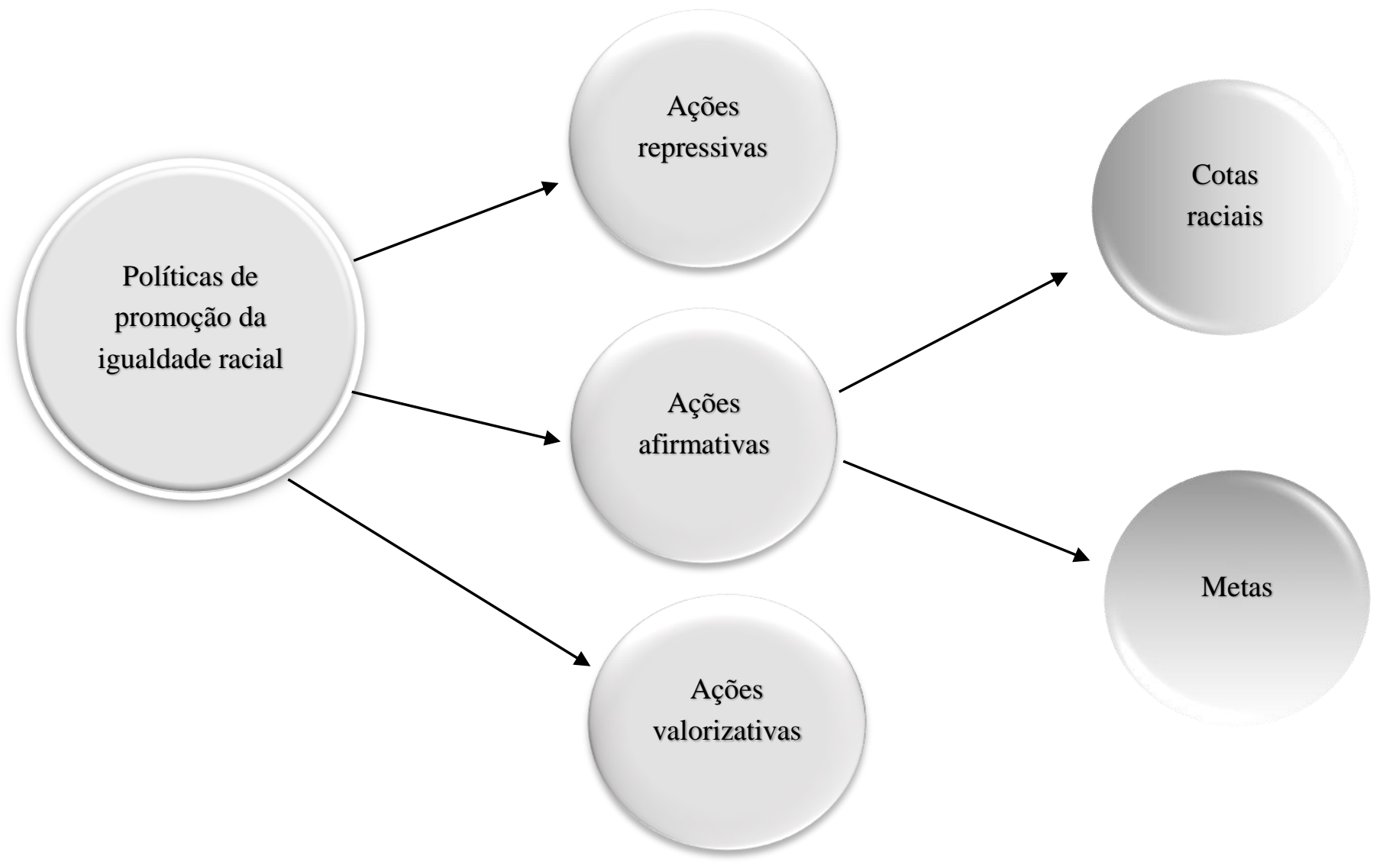

Figura 1 - Sistematização das políticas de promoção da igualdade racial

Jaccoud e Beghin (2002) construíram uma tipologia analítica para as políticas de promoção da igualdade racial. Esta tipologia está estruturada em três tipos de ações: afirmativas, repressivas e valorizativas.

Para essas autoras, as ações afirmativas têm por objetivo garantir a oportunidade de acesso dos grupos discriminados, ampliando sua participação em diferentes setores da vida econômica, política, institucional, cultural e social. Tais ações se caracterizam por serem temporárias e por serem focalizadas no grupo discriminado; ou seja, por dispensarem, num determinado prazo, um tratamento diferenciado e favorável com vistas a reverter um quadro histórico de discriminação e exclusão. Gomes (2001) atesta o conceito de ações afirmativas:

Atualmente, as ações afirmativas podem ser definidas como um conjunto de políticas públicas e privadas de caráter compulsório, facultativo ou voluntário, concebidas com vistas ao combate à discriminação racial, de gênero e de origem nacional, bem como para corrigir 
os efeitos presentes da discriminação praticada no passado, tendo por objetivo a concretização do ideal de efetividade da igualdade de acesso a bens fundamentais como educação e emprego (GOMES, 2001:40).

O fenômeno a ser enfrentado pelas ações afirmativas é a discriminação racial indireta. Discriminação indireta é "aquela que redunda em uma desigualdade não oriunda de atos concretos ou de manifestação expressa de discriminação por parte de quem quer que seja, mas de práticas administrativas, empresariais ou de políticas públicas aparentemente neutras, porém dotadas de grande potencial discriminatório" (GOMES, 2001:23).

A ação afirmativa visa à busca da igualdade e ao combate a toda forma de discriminação. A discriminação indireta é dissimulada, quase invisível e raramente tratada pelo Direito, que cegamente aplica o conceito de igualdade perante a lei sem levar em conta que a desigualdade pode vir da própria lei, conforme discute Gomes (2001).

Segundo Telles (2003), as políticas de ação afirmativa nos Estados Unidos têm um alcance amplo e as instituições que as adotam devem estabelecer metas e prazos para aumentar a representação das minorias em seus quadros; por meio dessas políticas os Estados Unidos monitoram o progresso em refletir a diversidade da população no governo e nas instituições privadas. As cotas raciais são diferentes nos Estados Unidos, elas somente são determinadas pelos tribunais em casos extremos quando há uma forte exclusão das minorias (Telles, 2003). De resto, o que se vê é a aplicação de ações afirmativas naquele país.

Apesar de seu posicionamento contrário às ações afirmativas, Sowell (2004) oferece-nos um mapa da ampla adoção dessas ações. $\mathrm{O}$ autor analisa as experiências com políticas de ações afirmativas em países como Índia, Malásia, Sri Lanka, Nigéria e Estados Unidos. Tanto as ações afirmativas quanto as cotas existem há tempos, já em 1840, por exemplo, na Nova Zelândia, por meio do Tratado de Waitangi, cujos beneficiados foram os Maoris (SOWELL, 2004). Gomes (2001) nos esclarece que, de início, nos Estados Unidos, as ações afirmativas eram definidas como um mero encorajamento por parte do Estado e das pessoas com poder de decisão nos espaços públicos e privados para promover a inclusão dos excluídos socialmente na educação e no mercado de trabalho, levando em consideração atributos como raça, cor, sexo e a origem nacional das pessoas, fatores que antes eram considerados como irrelevantes pela grande maioria dos dirigentes políticos e empresariais. 
Acontece que o propósito das ações afirmativas de refletir na escola e no mercado de trabalho a representação de cada grupo na sociedade, se mostrou ineficiente. Assim, no final da década de 1960 e início dos anos de 1970, continua Gomes (2001), os Estados Unidos ousaram ao impor cotas rígidas de acesso de minorias sociais nos setores educacionais e no mercado de trabalho. $\mathrm{O}$ autor nos ilumina, ao discutir que a jurisprudência dos Estados Unidos tem restrições às chamadas "cotas cegas, isto é, aquelas instituídas aleatoriamente, sem o propósito de corrigir uma injustiça precisa, que é a própria razão da existência das políticas de ação afirmativa" (GOMES, 2001:40).

Olhamos para os Estados Unidos em razão das semelhanças históricas, da localização geográfica e do perfil demográfico que nos torna muito próximos e passíveis de sermos comparáveis. No caso brasileiro, acreditamos que houve uma inovação com a instituição de cotas raciais como uma política de promoção da igualdade racial porque agimos diferente dos Estados Unidos, onde há grandes controvérsias na Suprema Corte ${ }^{4}$ sobre a instituição de políticas de cotas com a decretação de sua inconstitucionalidade, a despeito do reconhecimento de que raça poderia ser um fator positivo nos critérios de admissão no ensino superior (FERES JÚNIOR, 2006). Voltamos a Gomes (2001), que revisita a controvérsia na corte estadunidense e conclui que a jurisprudência da Suprema Corte considera compatíveis com a Constituição programas de favorecimento de minorias que utilizam raça ou sexo como instrumentos de classificação para implementar políticas públicas. Naquele país, as decisões contrárias às cotas versaram ou sobre as cotas cegas - "cotas instituídas sem sentido corretivo ou restaurador" (GOMES, 2001:231), ou sobre um aspecto específico de cada programa de ação afirmativa.

As ações repressivas são baseadas na legislação criminal existente e têm como fenômeno a ser enfrentado a discriminação racial direta. Discriminação direta é um comportamento, uma ação que prejudica explicitamente certa pessoa ou grupo de pessoas em decorrência de sua raça/cor (JACCOUD; BEGHIN, 2002). Ações repressivas eram o tipo de política pública priorizada até meados da década de 1990, não obstante, ações afirmativas tenham sido propostas por militantes negros na década de 1940 (NASCIMENTO, 2003) e por técnicos

\footnotetext{
${ }^{4}$ Caso de 1978, Regents of the University of California v. Bakke.
} 
do Ministério do Trabalho e do Tribunal Superior do Trabalho em 1968 (SANTOS, 1999 apud MOEHLECKE, 2002).

As ações valorizativas têm como objetivo reconhecer e valorizar a pluralidade étnica que marca a sociedade brasileira e valorizar a comunidade afro-brasileira, destacando tanto seu papel histórico como sua contribuição à construção nacional. Seu propósito é atingir não somente a população racialmente discriminada, contribuindo para que ela possa reconhecerse na história e na nação, mas atingir toda a população, permitindo-lhe identificar-se em sua diversidade étnica e cultural. No Brasil, ações valorizativas fundamentam um Estado que defende a pluralidade étnico-racial, diferentemente do Estado que até o final da década de 1980 defendia a assimilação e a unidade nacional em torno da mestiçagem (COSTA, 2001).

As ações valorizativas têm como fenômeno a ser enfrentado o racismo e o preconceito racial. Para Santos, H. (2001), racismo e preconceito racial são atitudes. O preconceito é entendido pelo autor como "modos de ver certas pessoas ou grupos raciais (...). Ocorre quando uma pessoa ou mesmo um grupo sofre uma atitude negativa por parte de alguém que tem como padrão de referência que lhe é próprio" (SANTOS, H. 2001:83). A discriminação racial e o racismo analiticamente não são as mesmas coisas. $\mathrm{O}$ racismo, ainda tomando a definição de Santos, "ocorre quando se atribui a um grupo determinados aspectos negativos em razão de suas características físicas ou culturais” (SANTOS, H. 2001:83). Quando há uma ação, um comportamento que tem por intenção prejudicar, é que há discriminação.

Apesar de seu caráter reativo, as ações repressivas são importantes, mas insuficientes para a efetiva promoção da igualdade racial, sobretudo pela tradição brasileira de dificilmente conseguir tipificar casos de discriminação racial em racismo, o que leva à exígua aplicação dos propósitos da legislação penal. Autores como Gomes (2000), Martins (2000) e Telles (2003) atribuem ao establishment jurídico - que representa setores conservadores - a inoperância das ações repressivas pelo Estado, pois alguns juízes parecem não acreditar que o brasileiro seja capaz de praticar racismo. Telles (2003) esclarece que essa descrença se deve aos valores antirracistas desses juízes, porque impera entre nós a ideologia da democracia racial. 
Outro aspecto das políticas de promoção da igualdade racial é que elas pressupõem elevarmos diferentes grupos raciais e étnicos aos mesmos padrões de qualidade de vida e de justiça social e econômica. Esses propósitos estão além das ações repressivas, envolvem tanto as ações afirmativas e valorizativas. Martins (2000) parece concordar com a nossa argumentação:

\footnotetext{
Entendemos, também, que os limites das legislações atuais são claros: visam atacar atos de discriminação e retirar barreiras impostas por práticas racistas. Porém, elas não vão suprir a grande deficiência de condições de concorrência às oportunidades de trabalho, ou de acesso à educação, que a maioria dos afro-brasileiros vivenciam. A legislação criminal ou civil não vai nos dar respostas a problemas para os quais não foram elaboradas. (MARTINS, 2000:430)
}

As ações afirmativas e valorizativas para a promoção da igualdade racial se fazem presentes, formalmente, nos planos governamentais desde meados da década de 1990. Entretanto, elas carecem de apoio institucional, sobretudo na sua implementação, pois lhes faltam recursos físicos, orçamentários e financeiros para a sua efetiva execução, além de um legítimo apoio político. Destacamos, entretanto, que apesar da luta do movimento negro desde a década de 1930 para a instituição de políticas públicas de enfrentamento da problemática racial, somente no final da década de 1980 é que o Estado começa a sinalizar com algumas ações (JACCOUD; BEGHIN, 2002; SANTOS, I.A.A., 2001; SANTOS, 2009).

Primeiramente, ressalta-se a promulgação da Constituição de 1988 que: i) reconheceu a igualdade de todos; ii) transformou o racismo em crime inafiançável; iii) determinou a proteção dos quilombos; iv) reconheceu as terras ocupadas pelos remanescentes de quilombos; e v) determinou a proteção da cultura afro-brasileira. Consideramos que a partir da promulgação da Constituição de 1988, o movimento social negro teve bases legais para cobrar uma atuação mais ampla do Estado na problemática racial. Não se trata assim de ignorar a atuação do movimento social negro ao longo de um período histórico mais amplo, desde a criação da Frente Negra Brasileira em 1930, e o seu banimento com a instituição do Estado Novo em 1937, até a mobilização da comunidade afro-brasileira na constituinte nacional (NASCIMENTO; NASCIMENTO, 2000; NASCIMENTO, 2003; SANTOS, I.A.A., 2001). 
A tarefa não é fácil, o tema é amplo, o que levaria a uma proposta de estudo específica sobre o protagonismo do movimento social negro na história política do Brasil. Iremos nos deter ao período da história recente do governo de Fernando Henrique Cardoso (1995-2002) até o governo de Luiz Inácio Lula da Silva (2003-2011) e atentarmo-nos às ações do Poder Executivo Federal, não ignorando que houve e há ações nos níveis estaduais e municipais fundamentais para o avanço das políticas nacionais. A nossa tentativa é descrever a continuação dos passos do movimento social negro na luta e defesa da inserção de políticas de promoção da igualdade racial na agenda governamental.

Durante o governo de Fernando Henrique Cardoso (1995-2002), esperava-se a instituição, de fato, de políticas públicas que enfrentassem a discriminação racial, o preconceito e o racismo contra a população negra. Pode-se entender que no período do governo FHC se deu a análise da política pública propriamente dita conforme descreve Lindblom (1980). Uma das falas do então presidente FHC abria a possibilidade de diálogo, o prenúncio de dificuldades e uma interação com o movimento social negro, que reivindicava a atuação do Estado e seu papel indutor:

\footnotetext{
Acredito que devamos discutir as várias fórmulas existentes para assegurar igualdade de oportunidades. Existem experiências nos Estados Unidos - algumas delas estão sendo revistas - que devem ser analisadas aqui, sobre a questão de oportunidades quase compulsórias para compensar os desequilíbrios sociais e as discriminações existentes. O governo está aberto a discuti-las com profundidade, sem precipitações. Está aberto a qualquer discussão levada a efeito com seriedade sobre essa matéria que encontra muita resistência em certos setores (Brasil, 1998 ${ }^{5}$ ).
}

Observamos que antes dessa fala de FHC, o movimento social negro havia organizado a Marcha de Palmares contra o Racismo, pela Cidadania e a Vida em 1995, em memória aos 300 anos da morte de Zumbi dos Palmares. Foi uma das primeiras ações do movimento social negro no sentido de pautar o governo FHC para a formulação e implementação de políticas públicas. E mesmo assim ao se passarem três anos pós-Marcha não havia uma determinação governamental na pessoa do Presidente da República para a instituição de políticas específicas que favorecessem a população negra. Por isso acreditamos que o

\footnotetext{
${ }^{5}$ Construindo a Democracia Racial - Presidência da República, Governo Fernando Henrique Cardoso, Presidência da República, Brasília, 1998.
} 
período FHC foi de análises e discussões que culminaram na atuação do movimento social negro na III Conferência Mundial contra o Racismo, a Discriminação Racial, Xenofobia e Intolerância Correlata, promovida pela Organização das Nações Unidas-ONU, realizada em Durban, África do Sul, em 2001.

Talvez a expectativa em relação ao governo FHC tenha sido grande para a instituição de políticas de promoção da igualdade racial. No seu programa de governo "Mãos à Obra, Brasil: Proposta de Governo" de 1994 (CARDOSO, 1994) há um conjunto de proposições para a população negra que fazem alusão a políticas sociais que promovam a igualdade de oportunidades. A trajetória acadêmica de Fernando Henrique Cardoso foi um outro aspecto que motivou a expectativa de avanços para a população negra durante o seu governo. $\mathrm{O}$ início da vida acadêmica do então presidente FHC foi marcado por temas relacionados à questão racial sob fundamentos sociológicos. Ele costumava citar a sua história ${ }^{6}$ em momentos públicos que envolvessem a questão racial. Segundo Paula (2010), que entrevistou membros do governo de FHC para o seu trabalho sobre as políticas afirmativas durante esse período de governo, os seus entrevistados acreditavam que a trajetória acadêmica tenha influenciado a decisão do ex-presidente a instituir algumas políticas de ações afirmativas em seu governo.

Os desdobramentos da Marcha de Zumbi dos Palmares foram iniciativas para promover o debate, o desenho de políticas públicas e a formação de uma agenda governamental, sendo: (i) a criação do Grupo de Trabalho Interministerial para Valorização da População Negra em 1995, que tinha como um dos seus objetivos propor ações integradas de combate à discriminação racial, visando ao desenvolvimento e à participação da População Negra (Decreto s/ n ${ }^{\circ}$, de 20 de novembro de 1995); (ii) a criação do Grupo de Trabalho para a Eliminação da Discriminação no Emprego e na Ocupação - GTEDEO, com o objetivo de definir programas de ações para combater a discriminação no emprego e na ocupação

\footnotetext{
${ }^{6}$ As pesquisas de FHC sobre negros no Brasil estão registradas nas seguintes publicações: CARDOSO, Fernando Henrique; IANNI, Octávio. Côr e mobilidade social em Florianópolis: aspectos das relações entre negros e brancos numa comunidade do Brasil meridional. Prefácio de Florestan Fernandes. São Paulo: Companhia Editora Nacional, 1960. xl, 286 p. (Brasiliana, v. 307); CARDOSO, Fernando Henrique. Capitalismo e escravidão no Brasil meridional: o negro na sociedade escravocrata do Rio Grande do Sul. São Paulo: Difel, 1962. (Tese de doutorado, PhD thesis).
} 
(Decreto $\mathrm{s} / \mathrm{n}^{\circ}$, de 20 de março de 1996); (iii) a realização do Seminário Internacional "Multiculturalismo e Racismo: o papel da ação afirmativa nos Estados democráticos contemporâneos" em 1996; (iv) a instituição do I Programa Nacional de Direitos HumanosPNDH (Lei no 1.904, de 13 de maio de 1996); (v) a instituição do Programa Diversidade na Universidade, com o objetivo de implementar e avaliar estratégias para a promoção do acesso ao ensino superior de pessoas pertencentes a grupos socialmente desfavorecidos, especialmente dos afrodescendentes e dos indígenas brasileiros (Lei $\mathrm{n}^{\mathrm{o}}$ 10.558, de 13 de novembro de 2002); (vi) a instituição do Programa Nacional de Ações Afirmativas (Decreto $\mathrm{n}^{\mathrm{o}}$ 4.228, de 13 de maio de 2002); (vii) os preparativos e a participação brasileira na III Conferência Mundial contra o Racismo, a Discriminação Racial, Xenofobia e Intolerância Correlata, promovida pela Organizações das Nações Unidas-ONU, realizada em Durban, África do Sul (Conferência de Durban).

As propostas apresentadas na Marcha não foram plenamente efetivadas no aparelho do Estado, mesmo com o cabedal de FHC. Entretanto, ali se lançou a pedra fundamental para pensar e implementar as políticas de promoção da igualdade racial, conforme revela trecho de depoimento de Sueli Carneiro ${ }^{7}$.

\begin{abstract}
A criação do Grupo de Trabalho Interministerial foi a resposta que o governo ofereceu à Marcha. A implementação das propostas construídas por aquele grupo, liderado pelo Hélio Santos, não alcançaram plena inclusão ou efetivação. Mas historicamente é preciso registrar que foi no contexto do governo Fernando Henrique Cardoso que as primeiras políticas de promoção da igualdade foram gestadas e implementadas. Isso é um fato histórico que tem que ser reconhecido. E que, no novo governo, acaba tendo novas dimensões com a criação da Secretaria Especial de Políticas de Promoção da Igualdade Racial, a Seppir, em 21 de março de 2003. (ALBERTI; PEREIRA, 2007:346)
\end{abstract}

Ainda assim, o então presidente FHC alegava que não tinha base política e uma forte demanda da sociedade para a instituição de ações mais concretas de combate à discriminação racial, como no caso das ações afirmativas:

\footnotetext{
${ }^{7}$ Entrevista ao CPDOC - Centro de Pesquisa e Documentação de História Contemporânea do Brasil da Fundação Getulio Vargas no dia 20/07/2004. Sueli Carneiro nasceu na cidade de São Paulo, em 24 de junho de 1950. Formada no curso de Filosofia da Universidade de São Paulo (USP) em 1980, foi uma das fundadoras do Coletivo de Mulheres Negras em São Paulo, em 1984, e conselheira e secretária-geral do Conselho Estadual da Condição Feminina do Estado. Coordenou o Programa da Mulher Negra do Conselho Nacional dos Direitos da Mulher, de março de 1988 a julho de 1989, e é uma das sócias fundadoras do Geledés Instituto da Mulher Negra, localizado em São Paulo, onde ocupa os cargos de coordenadora executiva e coordenadora do Programa de Direitos Humanos/SOS Racismo desde 1988. É doutora em Filosofia da Educação pela USP (ALBERTI; PEREIRA, 2007:34-35).
} 
(...) O problema aqui é complicado porque não existe abertamente. O próprio movimento negro está dividido na questão da ação afirmativa. Então, não tenho base política para avançar mais. É um assunto para pensar. Não sei se isso pode mudar só via governo, ou se a interferência do governo criaria uma dificuldade maior no processo. É preciso haver uma mudança na sociedade (Brasil, $1998^{8}$ ).

Talvez a instituição do I Programa Nacional de Direitos Humanos-PNDH, de 1996, tenha legitimado a decisão do Estado em lançar o Programa de Ações Afirmativas e Diversidade na Universidade. O I PNDH contou com um processo amplo de participação política. Houve seis seminários em que participaram 210 entidades, constituindo, portanto, um espaço de diálogo e parceria que culminou com a discussão do projeto do I PNDH na I Conferência Nacional dos Direitos, realizada em 1996. A discussão na Conferência contribuiu para se chegar ao texto final do I PNDH.

O I PNDH trazia em seus objetivos ações direcionadas à população negra: (i) apoiar as ações da iniciativa privada que realizem discriminação positiva; (ii) desenvolver ações afirmativas para o acesso dos negros aos cursos profissionalizantes, às universidades e às áreas de tecnologia de ponta; (iii) facilitar a discussão e a articulação entre as entidades da comunidade negra e os diferentes setores do Governo, para desenvolver planos de ação e estratégias na valorização da comunidade negra; (iv) formular políticas compensatórias que promovam social e economicamente a comunidade negra.

É interessante ressaltarmos como a atuação do movimento social negro, bem como a relação com a política partidária e o fato de o movimento ter representantes dentro do Estado, possibilitaram pautar a agenda de governo. Ivair Augusto Alves dos Santos ${ }^{9}$ foi um dos

\footnotetext{
${ }^{8}$ Construindo a democracia racial, Presidência da República, Governo Fernando Henrique Cardoso, Brasília, 1998.

${ }^{9}$ Entrevista ao CPDOC - Centro de Pesquisa e Documentação de História Contemporânea do Brasil da Fundação Getulio Vargas, nos dias 07/09/2004 e 01/07/2005. Ivair Augusto Alves dos Santos nasceu na cidade de São Paulo, em 10 de setembro de 1952. Formado em Química pela Universidade Federal de São Carlos em 1974, trabalhou em Angola, entre 1979 e 1983, como consultor da Unesco para o desenvolvimento do ensino de ciências naquele país. Ao retornar ao Brasil, foi um dos fundadores do Conselho de Participação e Desenvolvimento da Comunidade Negra do Estado de São Paulo, o primeiro órgão do poder público criado para tratar especificamente da questão racial, durante o governo de Franco Montoro (1983-1987). Trabalhou na Coordenadoria Especial do Negro, órgão da prefeitura de São Paulo, durante o final da gestão da prefeita Luiza Erundina, entre 1991 e 1992. No governo Fernando Henrique Cardoso, a partir de 1995, transferiu-se para Brasília, passando a atuar como assessor na então Secretaria de Justiça e Cidadania (que mudou de nome algumas vezes) do Ministério da Justiça, e foi o representante desse ministério no Grupo de Trabalho Interministerial para a Valorização da População Negra, de 1995 a 1996. À época da entrevista ao CPDOC, era secretário executivo do Conselho Nacional de Combate à Discriminação da Presidência. É mestre em
} 
membros do movimento negro que teve uma atuação central na condução dos temas de importância para a população negra dentro da agenda de governo. Vejamos o seu relato:

\begin{abstract}
O Fernando Henrique Cardoso começou a falar de racismo e a falar de ação afirmativa. Não era o Montoro, a quem eu tinha livre acesso. Então comecei a reunir todos aqueles documentos dos discursos dele, até produzir um documento que depois ele chamou de Construindo a Democracia Racial, que tem vários discursos do presidente, em que ele fala de racismo. Então o que acontecia? Eu tinha o respaldo do presidente da República falando que o racismo existia. E mais do que isso, ainda era favorável à ação afirmativa. Isso nos deu fôlego para peitar os outros. Peitar quer dizer criar condições de debate dentro da máquina governamental sobre o assunto. (ALBERTI; PEREIRA, 2007:356-357)
\end{abstract}

A atuação de Ivair Augusto Alves dos Santos iniciou juntamente com Hélio de Souza Santos ${ }^{10}$ na constituição do Conselho de Participação e Desenvolvimento da Comunidade Negra no governo de Franco Montoro, de 1983 a 1987 ${ }^{11}$. Tratam-se de dois assessores negros do então governador de São Paulo que trabalharam estrategicamente nos cargos de assessor especial e de assessor de gabinete, onde o fazer política era o cotidiano dessas funções (SANTOS, I. A. A., 2001). Quando Fernando Henrique Cardoso foi eleito Presidente da República e formou o seu governo trouxe quadros do governo de Franco Montoro. Isso demonstra que havia uma articulação política que estava se dando há tempos para a formação de uma agenda de políticas públicas que tivesse como problemática de intervenção a população negra, conforme apreendemos da fala de Carlos Alberto Medeiros ${ }^{12}$ :

Outro dia eu estava assistindo a uma palestra do Ivair, e ele falava como, ainda no governo Fernando Henrique, algumas iniciativas que o governo federal estava tomando eram resultado de algo que vinha

Ciência Política pela Universidade Estadual de Campinas, Unicamp (ALBERTI; PEREIRA, 2007:25-26). Atualmente, é doutor em Sociologia pela Universidade de Brasília e Assessor do Gabinete do Reitor da UnB (http://lattes.cnpq.br/9240926776991481 acessado em 10/03/2014).

${ }^{10}$ Hélio de Souza Santos graduou-se em Contabilidade (1969) e em Administração de Empresas (1970) pela Faculdade Mineira de Ciências Econômicas, diplomou-se mestre em Finanças (1980) e doutor em Administração (1988) pela USP. Pela mesma universidade, foi pesquisador do Núcleo de Estudos Interdisciplinares do Negro. No ano de 1995 integrou o Grupo de Trabalho Interministerial para a Valorização da População Negra. Estudioso da questão racial e da desigualdade social brasileira, publicou, entre outros, A busca de um caminho para o Brasil: a trilha do círculo vicioso (São Paulo, Senac, 2001). É professor do programa de mestrado em Educação, Administração e Comunicação da Universidade de São Marcos, em São Paulo, e da Fundação Visconde de Cairu, em Salvador. Em setembro de 2006 recebeu a Grã-Cruz da Ordem do Ipiranga no Palácio dos Bandeirantes (ALBERTI; PEREIRA, 2007:101-102). É Presidente do Conselho Deliberativo do BAOBA - Fundo para a Equidade Racial. É diretor presidente do IBD - Instituto Brasileiro da Diversidade, organização sem fins lucrativos voltada para o desenvolvimento da diversidade no mercado de trabalho (http://lattes.cnpq.br/3185542729369392 acessado em 10/03/2014).

11 A experiência do Conselho foi repetida em outros Estados, como Mato Grosso do Sul, Bahia, Rio Grande do Sul, Mato Grosso, Santa Catarina, Piauí e algumas capitais: São Paulo, Belém, Vitória, Belo Horizonte, Rio de Janeiro e Brasília (SANTOS, I.A.A., 2001:162-163).

${ }^{12}$ Alberti e Pereira (2007:352-353). 
sendo desenvolvido desde o governo Franco Montoro. Porque um número muito grande de quadros do governo Fernando Henrique veio do governo Franco Montoro, em 1983, em São Paulo. Lá já estavam o Hélio Santos, o Hédio Silva ${ }^{13}$ e esse pessoal todo cutucando. Então é o resultado de um trabalho. As coisas não vêm do nada. Esse pessoal também estava pensando nessas estratégias e disseminando esse negócio (ALBERTI; PEREIRA, 2007:352-353).

São casos de servidores públicos dentro de um governo que podem influenciar a formação de uma agenda. São os outsiders (PACHECO, 2010) sem vínculos permanentes com o Estado e que se fortalecem e ganham legitimidade em razão das suas trajetórias acadêmicas e políticas na defesa de determinados problemas que pairam sobre o Estado. Houve aí uma junção entre sociedade civil e Estado que fortaleceu a reivindicação do movimento social negro. Difícil saber o que veio primeiro, pois o movimento negro, ao mesmo tempo em que estava atuando em um espaço social mais amplo, atuava também dentro do Estado por meio das suas relações com membros do governo ou por seus ex-membros fazerem parte do quadro governamental daquele momento.

\begin{abstract}
Mas, na verdade, o que nos norteava era criar bases para que as pessoas entendessem que racismo era uma coisa de política pública e criar algum substrato para discutir ação afirmativa. Sempre foi essa a nossa pauta. E o governo trabalhava num ritmo. Quando a Marcha Zumbi dos Palmares chegou aqui, deu a impressão de que a Marcha é que criou o GTI. Mas na verdade o GTI já estava pronto. Foi uma coisa que foi construída no governo. Não foi feita pela sociedade civil. O governo fez e apresentou (Entrevista de Ivair Augusto Alves dos Santos ao CPDOC - ALBERTI; PEREIRA, 2007:355).
\end{abstract}

Não entendemos o movimento social negro como um sujeito coletivo coeso quando levanta as suas bandeiras de luta, pois no nosso entender o movimento social negro é a constituição de diversos movimentos que reivindicam a melhoria de vida da população negra (ALBERTI; PEREIRA, 2006; SANTOS, 2009). Há diversas facetas desse movimento, diferentes pontos de vista, há disputa pelo espaço político, de ideias e de representação. Alguns atores importantes naquele momento, da Marcha de Zumbi de Palmares, trazem indícios da mobilização do movimento social negro como determinante para a concretização dessa manifestação.

\footnotetext{
${ }^{13}$ Hédio Silva Júnior nasceu em Três Corações (MG), em 24 de junho de 1961. Com cerca de quatro anos mudou-se com a família para São José dos Campos (SP), onde foi criado. Em 1986 mudou-se para a cidade de São Paulo para integrar o Conselho de Participação e Desenvolvimento da Comunidade Negra do Estado e, no mesmo ano, foi presidente da Convenção Nacional do Negro, realizada em Brasília. Foi assessor especial de Cidadania e Direitos Humanos da Prefeitura de São Paulo nos anos de 1991 e 1992. Nesse último ano fundou em São Paulo o Centro de Estudos das Relações de Trabalho e Desigualdade (CEERT). Advogado e doutor em Direito Constitucional pela PUC de São Paulo, foi Secretário de Justiça e Cidadania do governo paulista de maio de 2005 a março de 2006 (ALBERTI; PEREIRA, 2007:24-25).
} 
Qual era a conversa comigo? Se o Presidente receberia. "Vai receber ou não vai receber". O Sérgio Amaral disse: "Edson, o presidente não pode ser constrangido. Então, nós precisamos saber exatamente quem vai subir" (...) E o Sérgio Amaral ${ }^{14}$ me disse que o Fernando Henrique tinha intenção real de fazer ação afirmativa. Eu ainda brinquei e falei assim: "Ele pretende ser um Kennedy brasileiro então?" Ele falou: "Sim pretende". E enfatizou a sinceridade de Fernando Henrique em relação a implementar políticas públicas em benefício da população negra. E disse: "Edson, nós somos um governo de aliança e há forças na aliança que estão puxando o presidente da República para a Serra da Barriga. Então, há compromissos e o presidente vai conciliar. Ele vai à Serra da Barriga ${ }^{15}$, mas eu assumo com você o compromisso de que o presidente volta para receber a Marcha." (Entrevista de Edson Cardoso ${ }^{16}$ ao CPDOC - ALBERTI; PEREIRA, 2007:344).

Acho que, depois do centenário da Abolição, das ações, das marchas que fizemos por conta do centenário, a Marcha Zumbi dos Palmares pela Cidadania e a Vida, de 1995, foi o fato político mais importante do movimento negro contemporâneo. Acho que foi um momento também emblemático, em que nós voltamos para as ruas com uma agenda crítica muito grande e com palavras de ordem muito precisas que expressavam a nossa reivindicação de políticas públicas que fossem capazes de alterar as condições de vida da nossa gente (Entrevista de Sueli Carneiro ao CPDOC - ALBERTI; PEREIRA, 2007:345).

\title{
A articulação política com outros movimentos sociais como os sindicatos e partidos políticos
} de oposição foi também outra estratégia adotada pelo movimento social negro na tentativa de pautar a agenda governamental.

\begin{abstract}
Qual foi a vantagem que nós tivemos em 1995? O governo era Fernando Henrique Cardoso, e aí PT e CUT fizeram a sua avaliação de que poderia ser interessante a Marcha. (...) Em Brasília, Zé Dirceu estava na Marcha, Lula estava na Marcha, eu tenho fotos. Eles vieram todos com a bandeira do PT (...) porque a gente dependia muito dessa relação com o movimento sindical. Queríamos ter um diálogo com ele, mas não queríamos estar subordinados (Entrevista de Edson Cardoso ao CPDOC ALBERTI; PEREIRA, 2007:339, 341-342)
\end{abstract}

\footnotetext{
${ }^{14}$ Sérgio Amaral foi Secretário de Comunicação Social da Presidência da República durante quase todo o primeiro governo Fernando Henrique Cardoso, entre 10 de maio de 1995 e $1^{\circ}$ de janeiro de 1999 (ALBERTI; PEREIRA, 2007:344).

${ }^{15}$ Serra da Barriga: Parque Memorial Quilombo dos Palmares localizado em União dos Palmares, Alagoas.

${ }^{16}$ Entrevista ao CPDOC - Centro de Pesquisa e Documentação de História Contemporânea do Brasil da Fundação Getulio Vargas, no dia 28/04/2006. Edson Cardoso nasceu na cidade de Salvador, em 10 de outubro de 1949. Em 1973, entrou para a Universidade Federal da Bahia, no curso de Letras, que abandonou no quarto ano para ir morar em Porto Alegre. Em 1980, já vivendo em Brasília, fez novo vestibular para a Universidade de Brasília, onde terminou a graduação em Letras e fez o curso de mestrado em Comunicação. Professor de Literatura da rede particular de ensino, entre 1981 e 1995 foi militante do MNU - Movimento Negro Unificado em Brasília, e em 1984 foi fundador da Comissão do Negro do Partido dos Trabalhadores na Capital Federal. Participou da coordenação executiva da Marcha Zumbi dos Palmares Contra o Racismo, pela Cidadania e a Vida, em 1995. Foi chefe de gabinete do deputado Florestan Fernandes (PT-SP), entre 1992 e 1995, e responsável pela criação, em 1997, da Assessoria de Relações Raciais da Câmara dos Deputados, quando o deputado Paulo Paim (PT-RS) foi eleito terceiro secretário da mesa da Câmara, cargo que exerceu entre 1997 e 1999; foi também chefe de gabinete do deputado Benh-Hur Ferreira (PT-MS, 1999-2000 e 2002-2003) e assessor de relações raciais no Senado, quando o senador Paulo Paim era primeiro vice-presidente da Casa, entre 2003-2005. Na época da entrevista ao CPDOC era coordenador editorial do jornal İrohìm, do qual foi fundador em 1995.
} 
O processo de análise e discussão das pautas propostas pelo movimento social negro para o governo FHC consubstanciam-se em um outro momento de grande importância para alavancar as bandeiras desse movimento. A atuação do governo brasileiro na Conferência de Durban, conforme relato de Jurema Batista ${ }^{17}$ :

\begin{abstract}
Então fomos para Durban, uma delegação imensa - fora da África, a maior delegação era a nossa. Quando chegamos lá, tivemos inclusive o poder de influenciar outras delegações. Nós éramos referência até para países africanos, que procuravam a gente para discutir nos bastidores. Uma surpresa. Outra surpresa boa foi que, na época, o governo brasileiro comprou a ideia. Tanto que Fernando Henrique mandou ministros, um monte de gente; parte dessa grande delegação teve inclusive verba federal (...) Já não era mais só o movimento negro fazendo defesa; o governo brasileiro fez as defesas do que nós decidimos nas conferências municiais e estaduais. Então essa é a avaliação que eu tenho: que o governo brasileiro encampou a nossa retórica (ALBERTI; PEREIRA, 2007:386387)
\end{abstract}

Em vista disso, a sociedade civil foi quem impulsionou o Estado para uma demanda recorrente que ele (o Estado) considerava como uma não situação. Entretanto, as ações de implementação das políticas formuladas por meio de leis e decretos não tiveram o impacto desejado. Jaccoud e Beghin (2002), ao analisarem a intervenção governamental desse período identificado, reconhecem que as ações empreendidas estavam longe do desejado e do necessário.

Os processos de articulação e maturação política são longos. Desde o estabelecimento de alianças com quem se conhece, como afirmou um de nossos dirigentes entrevistados, articular com parceiros em potencial, até a implementação de políticas públicas que foram aprovadas. No período FHC o que se deu foi a análise do processo de decisão política, isso aconteceu muito mais pela falta de janelas de oportunidade políticas para ir além das discussões e elaboração de atos administrativos de menor impacto do que pelo

\footnotetext{
${ }^{17}$ Entrevista ao CPDOC - Centro de Pesquisa e Documentação de História Contemporânea do Brasil da Fundação Getulio Vargas, nos dias 26/04/2004 e 11/11/2004. Jurema Batista nasceu na cidade do Rio de Janeiro, em 9 de agosto de 1957. Foi fundadora e presidente da Associação de Moradores do Morro do Andaraí, em 1980, e, nesse mesmo ano, entrou no curso de Letras da Universidade Santa Úrsula, que concluiu em 1983. Participou da fundação do Nzinga - Coletivo de Mulheres Negras, também em 1983. Foi vereadora da cidade do Rio de Janeiro na legenda do PT durante três mandatos consecutivos: 1992-1996, 1996-2000 e 2000-2002 - este último interrompido na metade, quando se elegeu deputada estadual pelo Rio de Janeiro. Em dois mandatos foi presidente da Comissão de Defesa dos Direitos Humanos da Câmara Municipal. À época da entrevista ocupava uma cadeira na Assembleia Legislativa do Estado do Rio de Janeiro (Alerj), onde presidia a Comissão de Combate às Discriminações e Preconceitos de Raça, Cor, Etnia, Religião e Procedência Nacional (ALBERTI; PEREIRA, 2007:28). É suplente de vereadora pelo PT no Rio de Janeiro (http://www.eleicoes2012.info/jurema-batista-13663/ acessado em 10/03/2014)
} 
distanciamento do movimento social negro em relação ao Estado. Muito além das realizações efetivas que quaisquer proposições feitas no primeiro mandato de FHC alcançaram, um aspecto importante a ressaltar na atuação do movimento social negro foi o exercício de protagonismo e aprendizado na/sobre a estrutura do Estado. Em 2001, esses aspectos foram demonstrados na realização da III Conferência Mundial contra o Racismo, a Discriminação Racial, Xenofobia e Intolerância Correlata, promovida pela Organização das Nações Unidas-ONU, realizada em Durban, África do Sul. A começar pela relatora da ONU para essa Conferência, Edna Roland, brasileira e militante do movimento social negro.

\begin{abstract}
O negócio não é ir para as declarações; é ir para as negociações. E fui lá nessas salinhas, que eram menores, e grudei no embaixador Gilberto Saboia, acompanhando as negociações de parágrafos. Quando eu achava que tinha alguma sugestão para fazer, grudava no ouvido dele, passava por escrito: "Embaixador, diga isso, faça isso...". Tinha que dar instrumentos para que ele pudesse intervir no debate (...) Eles acharam que era mais relevante pedir a relatoria, exatamente porque a relatoria é única, enquanto que vice-presidência são três. A segunda avaliação do Brasil foi que eles achavam que deveriam indicar uma pessoa da sociedade civil. No dizer do embaixador, para expressar essa relação muito forte de colaboração que aconteceu entre a sociedade civil e o governo, durante o processo de Durban (...) Agora, eu considero que há uma carga simbólica forte nessa questão das funções. É uma expressão da correlação de forças entre países. Então há todo um investimento por parte dos países para estar nessas posições e nesses lugares, não somente pela ação concreta e prática que vai ser desenvolvida - não se sabe se aquele indivíduo mesmo vai fazer isso ou aquilo -, mas pela correlação de forças que você está apontando para o mundo quando fulano está na presidência, outro está na relatoria e assim por diante. (ALBERTI; PEREIRA, 2007: 381,384, 386) ${ }^{18}$
\end{abstract}

Como resultado da Conferência de Durban houve o compromisso internacional do Estado brasileiro de promover políticas de melhoria para a população negra, sobretudo nos espaços que dependiam apenas de decisão presidencial.

\begin{abstract}
Ainda no final do governo Fernando Henrique Cardoso, a partir da Conferência, nós começamos a avançar na ação afirmativa, criando várias portarias ministeriais no MDA, depois na Justiça, na Cultura, criando programas de ação afirmativa nos ministérios. Mas aí era um programa muito concreto: era percentual de cotas para negros nos serviços terceirizados e nos DAS, cargos de
\end{abstract}

\footnotetext{
${ }^{18}$ Entrevista ao CPDOC - Centro de Pesquisa e Documentação de História Contemporânea do Brasil da Fundação Getulio Vargas, no dia 22/07/2004. Edna Maria Santos Roland nasceu na cidade de Codó (MA), em 12 de janeiro de 1951. Quando tinha sete anos mudou-se com a família para Fortaleza, onde viveu até os dez anos. A partir de então, viveu com a família em Goiânia, até iniciar o curso de Psicologia na UFMG, em Belo Horizonte, em 1969. Participou da fundação do Coletivo de Mulheres Negras em São Paulo, em 1984; foi membro do Conselho Estadual da Condição Feminina de São Paulo, em 1988, e uma das fundadoras do Geledés Instituto da Mulher Negra, no mesmo ano. Em 1996 fundou a Fala Preta! Organização de Mulheres Negras, instituição da qual é presidente de honra. De fevereiro a junho de 1998 foi pesquisadora visitante do Harvard Center for Population and Development Studies, Cambridge, nos Estados Unidos. Foi eleita Relatora Geral da III Conferência Mundial contra o Racismo, a Discriminação Racial, Xenofobia e Intolerância Correlata, promovida pela Organização das Nações Unidas-ONU, em Durban, na África do Sul, em 2001. Na época da entrevista era coordenadora de Combate ao Racismo e à Discriminação Racial para América Latina e Caribe, da Unesco no Brasil (ALBERTI; PEREIRA, 2007: 22).
} 
confiança. A gente começou a descobrir que o nosso potencial era muito maior. Por quê? Qual é o critério para se contratar alguém? No serviço público, é o concurso. E nos serviços terceirizados? Quem indicou? Então nós começamos a perceber que o negro não estava lá. Aí eu pergunto: “Qual o critério para você ser chefe ou diretor no serviço público?” É claro que não tem critério técnico para isso. Então, se havia um lugar em que nós tínhamos que ter ação afirmativa era com os DAS e era nos serviços terceirizados. São coisas que a gente vai aprendendo ao longo do tempo. Precisava saber quem tinha DAS e qual era a cor das pessoas. Nós fizemos um censo e sensibilizamos as pessoas sobre o censo, para a coisa acontecer. Isso era no final do governo. O censo foi importante para a gente poder dar outro passo importante, que foi o seguinte: um decreto presidencial criando um programa de ação afirmativa, o Decreto 4.228, que estendia as ações afirmativas para todos os órgãos federais. Depois do decreto, depois disso tudo, quem entrasse no governo só restava fazer uma coisa. O que era? Criar uma secretaria (Entrevista de Ivair Augusto Alves dos Santos ao CPDOC - ALBERTI; PEREIRA, 2007:388-389).

Podemos destacar dentro do quadro político do governo FHC para a população negra a instituição do Grupo de Trabalho Interministerial para a Valorização da População Negra, a Conferência de Durban e a abertura do debate sobre a instituição de ações afirmativas para a população negra. $\mathrm{O}$ que reflete o reconhecimento do Estado das bandeiras do movimento social negro e a progressiva conquista de espaço na agenda governamental de temas afeitos à melhoria das condições de vida da população negra.

Com a eleição do presidente Luiz Inácio Lula da Silva, Lula, em 2003, é criada a Secretaria Especial de Políticas de Promoção da Igualdade Racial-SEPPIR, vinculada à Presidência da República com status de Ministério. Até esse momento, no aparelho do Estado, a única instituição com mandato para tratar da questão racial era a Fundação Cultural Palmares-FCP, criada em 1988, vinculada ao Ministério da Cultura. Entretanto, o espaço de atuação da FCP para tratar da problemática racial era marcadamente cultural.

A SEPPIR é, formalmente, um órgão de articulação, cujo objetivo básico é a formulação, coordenação, planejamento e articulação de políticas e diretrizes para a promoção da igualdade racial. O desafio da SEPPIR é trabalhar com os demais órgãos do governo federal para a instituição de políticas transversais que deem conta da questão racial. Durante a campanha eleitoral, o Programa de Governo 2002 Coligação Lula Presidente já trazia um conjunto de ações de combate à desigualdade racial no documento intitulado Programa Brasil sem Racismo ${ }^{19}$. A previsão era que as ações seriam executadas em todos os setores

\footnotetext{
${ }^{19}$ Programa de Governo 2002 - Um Brasil para Todos.
} 
da problemática racial. Esse compromisso foi reafirmado durante a campanha eleitoral em $2006^{20}$.

As políticas públicas de promoção da igualdade racial desenhadas e/ou implementadas durante o período de 2003 a 2011 (Governo Lula) foram: (i) Política Nacional de Saúde Integral da População Negra; (ii) Programa Brasil Quilombola; (iv) Plano Setorial de Qualificação (Planseq) Trabalho Doméstico Cidadão; (v) Plano Nacional de Implantação da Lei n ${ }^{\circ} 10.639$ (que altera a Lei de Diretrizes e Bases da Educação-LDB, e torna obrigatório o ensino de história e cultura da África e das populações negras brasileiras nas escolas de ensino fundamental e médio de todo o país); (vi) Programa Institucional de Bolsas de Iniciação Cientifica (PIBIC-Ações Afirmativas); (vii) Programa de Combate ao Racismo Institucional; (viii) Estatuto da Igualdade Racial; (ix) Programa Cultura Afro-Brasileira (já em execução antes do governo Lula); (ix) Programa Universidade para Todos (que prioriza os afrodescendentes nos seus critérios de seleção); (x) Programa de Ações Afirmativas para a População Negra nas Instituições Federais e Estaduais de Educação Superior (Uniafro); (xi) Programa de Promoção de Políticas Afirmativas para Igualdade Racial; (xii) Programa de Promoção da Igualdade de Oportunidades para Todos.

Essas iniciativas tiveram a participação da SEPPIR como órgão articulador e de monitoramento. São diversos os órgãos governamentais que estiveram à frente das políticas relacionadas acima, como Ministério da Educação, Ministério da Saúde, Ministério Público do Trabalho, Ministério do Trabalho e Emprego e Ministério da Cultura. A despeito dessas articulações institucionais, Theodoro (2008) enumera quatro obstáculos para a construção e implementação de uma agenda política que promova verdadeiramente a igualdade racial: (i) o caráter residual das políticas públicas; (ii) a ausência de uma base conceitual para a formulação das políticas e programas; (iii) a mescla entre a questão racial e pobreza no desenho das políticas públicas; (iv) o racismo institucional.

O Estatuto da Igualdade Racial foi uma tentativa de construir uma referência legal e política para a elaboração de políticas públicas voltadas à promoção da igualdade racial. Entretanto, o processo de negociação do Estatuto da Igualdade Racial no Congresso Nacional é um

${ }^{20}$ Programa de Governo 2007-2010 - Lula de Novo com a Força do Povo. 
exemplo dos empecilhos às demandas do movimento social negro para a efetividade das políticas de promoção da igualdade racial. Um dos achados de Alencar (2011), ao analisar o contexto sociopolítico da aprovação do Estatuto da Igualdade Racial pelo Congresso Nacional em 2010, foi descrever a partir das falas dos entrevistados que a ideologia da democracia racial no Brasil é um forte obstáculo ao avanço da agenda propositiva do movimento social negro. O mito da democracia racial sustenta a crença de que não há racismo no Brasil e que estamos construindo uma sociedade mais justa (BERNARDINOCOSTA, 2002). E, também, fortalece a crença de que qualquer identificação racial e ação focalizada na população negra é uma tentativa de divisão da sociedade brasileira.

Uma das ações que desembocaram no governo Lula foi a instituição das cotas para estudantes negros no ensino superior. Apesar de ter sido uma decisão tomada pelas instâncias administrativas das universidades públicas, o fato explodiu a partir de 2003 com o ingresso de estudantes negros pelo sistema de cotas na Universidade Estadual do Rio de JaneiroUerj $^{21}$, e em 2004, na Universidade de Brasília. Talvez essa tenha sido uma das ações que mais fizeram ressoar a problemática racial no Brasil. Autores como Alberti e Pereira (2006) acreditam que a defesa das cotas foi uma estratégia política do movimento social negro contemporâneo. Nenhum assunto foi tão destacado no debate sobre a questão racial, onde se dividiram opiniões entre aqueles que defendiam e os que não aprovavam a instituição de cotas para negros no ensino superior. Até mesmo muitos intelectuais que trabalharam ao longo de sua trajetória acadêmica com o problema das relações raciais no Brasil estiveram no fronte de batalha contrário ao que defendia o movimento social negro.

Para o movimento social negro a discussão sobre as cotas trouxe ao cenário nacional aquilo que há décadas estava sendo denunciado, o mito da democracia racial e o grau de racismo na sociedade brasileira. A despeito de haver na legislação brasileira previsão de cotas para mulheres nos partidos e na aposentadoria; cotas para deficientes físicos nos concursos públicos e cotas para filhos de fazendeiros nas universidades rurais, o debate sobre as cotas

\footnotetext{
${ }^{21}$ Lei Estadual $\mathrm{n}^{\circ}$ 4151, promulgada pela Assembleia Legislativa do Estado do Rio de Janeiro, institui um sistema de cotas nas universidades públicas do Estado, reservando pelo menos $45 \%$ das vagas para 3 categorias de alunos, com uma exigência extra de que todos sejam carentes. Deste total, $20 \%$ são para estudantes oriundos da rede pública; $20 \%$ para negros; e 5\% para "pessoas com deficiência, nos termos da legislação em vigor e integrantes de minorias étnicas". (Gemma: http://gemaa.iesp.uerj.br/dados/linha-do-tempo.html, acessado em 18/07/2014).
} 
raciais se opunha a qualquer proposição de instituição de ações afirmativas para a população negra $\mathrm{O}$ que estava sendo considerado era a impossibilidade da mesma tentativa para os negros: "O problema dessa cota que está se discutindo agora não é a cota, mas a cor da cota, já que a cota é aceitável na sociedade brasileira. O problema é fazer isso em relação aos negros" (Entrevista de Carlos Alberto Medeiros ao CPDOC - ALBERTI; PEREIRA, 2007:398).

O relatório que o governo brasileiro apresentou para a Conferência de Durban já trazia a proposição de cotas para negros no ensino superior.

\begin{abstract}
A cota entrou no relatório oficial do governo que foi para a Conferência de Durban, quando eu, com um grupo de pessoas, numa audiência com o Presidente da República, sugeri ao Fernando Henrique que adotasse nem que fosse a cota, no relatório. Porque abriria o debate. E ele aí assumiu. Tanto que a imprensa foi lá e pinçou justamente a cota. Ao mesmo tempo em que ela pinçou para desmoralizar, abriu o debate (Entrevista de Ivanir dos Santos ${ }^{22}$ ao CPDOC - ALBERTI; PEREIRA, 2007:393).

(...) Mesmo porque o relatório me interessava, ele expressou boa parte daquilo que o movimento negro entendia que era mais importante. Inclusive as cotas, que foi no que a mídia mais se fixou. Quem ler o documento que o Brasil levou para a África do Sul vai ver que tem um monte de proposições Mas a mídia destacou "cota na universidade". Para nós foi bom inclusive. Olhando com o olhar de hoje, não foi tão ruim, foi bom (Entrevista de Hédio Silva Júnior ao CPDOC, em 21/07/2004 - ALBERTI; PEREIRA, 2007:378).
\end{abstract}

Apesar da instituição de cotas raciais em algumas universidades públicas, Jaccoud (2008), ao analisar a implementação de alguns programas do nível federal no governo Lula, chama a atenção para a baixa efetividade da execução. A autora imputa a dificuldade ao racismo institucional que opera de forma difusa por meio de procedimentos normativos e burocráticos. A autora ressalta, também, a letargia institucional da SEPPIR como órgão coordenador da política de promoção da igualdade racial.

\footnotetext{
${ }^{22}$ Entrevista ao CPDOC - Centro de Pesquisa e Documentação de História Contemporânea do Brasil da Fundação Getulio Vargas, no dia 01/12/2003. Ivanir dos Santos nasceu na cidade do Rio de Janeiro em 12 de julho de 1954. Foi criado no Sistema de Atendimento ao Menor (SAM) e na Fundação Nacional para o BemEstar do Menor (Funabem). Formado em Pedagogia pela Faculdade Notre Dame, no Rio de Janeiro, em 1984; fundou a Associação dos Ex-alunos da Funabem (Asseaf) em 1980, e o Centro de Articulação das Populações Marginalizadas (Ceap), em 1989. Participou da comissão de organização do I Encontro Nacional de Entidades Negras (Enen), em 1991, e da coordenação executiva da Marcha Zumbi dos Palmares contra o Racismo pela Cidadania e Vida, em 1995. Foi Subsecretário Estadual de Direitos Humanos e Cidadania durante o governo Anthony Garotinho, no Rio de Janeiro, na gestão de Abdias Nascimento, em 1999.
} 
Ocorre que o problema da desigualdade racial e a sua inserção nas políticas públicas devemse dar transversalmente nas áreas sociais, de infraestrutura, de planejamento e econômica da administração pública. E a transversalidade é um desafio para as políticas públicas de promoção da igualdade racial. Oliveira, D.D. (2009) chega a essa mesma conclusão. O autor verifica que a maioria das instituições governamentais que trabalham com políticas de promoção da igualdade racial possuem estruturas fluídas e de baixo status políticoadministrativo quando comparadas ao conjunto de órgãos municipais e estaduais. A implementação de políticas públicas transversais é um processo novo e obscuro para a maioria dos responsáveis por programas governamentais (SILVA et al, 2011). Agrega-se a isto, no caso das ações de promoção da igualdade racial, o imaginário da democracia racial, pois há gerentes governamentais que entendem que as políticas universais dariam conta de resolver todas as desigualdades ainda existentes (SILVA et al., 2011).

\subsection{Políticas de promoção da igualdade racial: além da justiça compensatória, os princípios de reconhecimento e redistribuição}

Muito além de apresentarmos categorias e definições de políticas de promoção da igualdade racial, a natureza dessas políticas sob o aspecto filosófico nos propicia a elaboração de uma defesa do seu desenvolvimento pela estrutura do Estado. Primeiramente, gostaríamos de tratar nesta seção da análise de Fraser-Honneth sobre reconhecimento e redistribuição e a aplicabilidade dessa teoria à natureza das políticas de promoção da igualdade racial. As dimensões do reconhecimento e redistribuição tratadas por Fraser e Honneth possuem um leque de controvérsias que podem ser aplicadas à natureza das políticas de promoção da igualdade racial.

A proposta teórica de Honneth (2003) constrói o paradigma do reconhecimento como uma questão de identidade, em que a identidade de um indivíduo ou de grupos é formada a partir do reconhecimento ou não reconhecimento dado pelo outro. $O$ autor baseia a sua argumentação em Hegel e Mead, o que o distancia de uma realidade mais política para se aproximar da discussão filosófica. Honneth (2003) reconstrói a teoria do reconhecimento por meio do amor, do direito e da estima social. O amor é a primeira experiência de 
reconhecimento recíproco, e o autor recomenda a máxima neutralidade possível na análise do termo "amor" na aplicação de sua teoria.

\begin{abstract}
Por relações amorosas devem ser entendidas aqui todas as relações primárias, na medida em que elas consistam em ligações emotivas fortes entre poucas pessoas, segundo o padrão de relações eróticas entre dois parceiros, de amizades e de relações pais/filhos (...) a relação amorosa representa de forma ideal uma simbiose quebrada pelo reconhecimento (...) visto que essa relação de reconhecimento prepara o caminho para uma espécie de autorrelação em que os sujeitos alcançam mutuamente uma confiança elementar em si mesmos, ela precede, tanto lógica como geneticamente, toda outra forma de reconhecimento recíproco: aquela camada fundamental de uma segurança emotiva não apenas na experiência, mas também na manifestação das próprias carências e sentimentos, propiciada pela experiência intersubjetiva do amor, constitui o pressuposto psíquico do desenvolvimento de todas as outras atitudes de autorrespeito." (HONNETH, 2003:159,177)
\end{abstract}

A ligação simbiótica da relação amorosa "quebrada pelo reconhecimento" cria a autoconfiança, que é a base indispensável para a participação autônoma na vida pública segundo Honneth (2003:177). Essa primeira etapa de reconhecimento dá-se em um círculo de convívio fechado das pessoas, em que se constroem a autoestima e o respeito próprio. Essa capacidade de autoconfiança e autorrespeito é a base para as relações com o outro.

O direito, por sua vez, também nos faz conceber uma forma de reconhecimento recíproco, sendo uma ação dupla de direitos e deveres que permite ao sujeito se reconhecer beneficiário de direitos e, por outro lado, reconhecer suas obrigações em relação ao outro.

Só podemos chegar a uma compreensão de nós mesmos como portadores de direitos quando possuímos, inversamente, um saber sobre quais obrigações temos de observar em face do respectivo outro: apenas da perspectiva normativa de um "outro generalizado", que já nos ensina a reconhecer os outros membros da coletividade como portadores de direitos, nós podemos nos entender também como pessoa de direito, no sentido de que podemos estar seguros do cumprimento social de algumas de nossas pretensões (HONNETH, 2003:179).

São seres humanos dotados da mesma igualdade, de direitos e deveres, que se reconhecem mutuamente como tais o que gera um status de respeito, pois os "sujeitos se respeitam mutuamente quando se reconhecem como pessoas de direito" (HONNETH, 2003:187). Uma compreensão que leva Honneth a estabelecer comparações entre o reconhecimento jurídico e a estima social, que poderíamos chamar de respeito e apreço ao outro.

Em ambos os casos, como já sabemos, um homem é respeitado em virtude de determinadas propriedades, mas no primeiro caso se trata daquela propriedade universal que faz dele uma pessoa; no segundo caso, pelo contrário, trata-se das propriedades particulares que o caracterizam, 
diferentemente de outras pessoas. Daí ser central para o reconhecimento jurídico a questão de como se determina aquela propriedade constitutiva das pessoas como tais, enquanto para a estima social se coloca a questão de como se constitui o sistema referencial valorativo no interior do qual se pode medir o "valor" das propriedades características" (HONNETH, 2003:179).

Honneth afirma que não basta o reconhecimento recíproco e jurídico, as pessoas necessitam se referir positivamente nas suas propriedades e capacidades concretas.

A estima social se aplica às propriedades particulares que caracterizam os seres humanos em suas diferenças pessoais (...) deve se expressar as diferenças de propriedades entre sujeitos humanos de maneira universal, isto é, intersubjetivamente vinculante (...) a autocompreensão cultural de uma sociedade predetermina os critérios pelos quais se orienta a estima social das pessoas, já que suas capacidades e realizações são julgadas intersubjetivamente, conforme a medida em que cooperaram na implementação de valores culturalmente definidos (HONNETH, 2003:199-200).

Honneth desenvolve a sua teoria de reconhecimento tratando a redistribuição em função do reconhecimento porque é "um instrumento apropriado para iluminar experiências sociais de injustiça como um todo" (FRASER; HONNETH, 2003:133). Partindo daí, Honneth afirma que a luta permanente dos grupos sociais nas sociedades modernas é elevar o valor das suas particularidades por meio simbólicos.

\footnotetext{
Quanto mais os movimentos sociais conseguem chamar a atenção da esfera pública para a importância negligenciada das propriedades e das capacidades representadas por eles de modo coletivo, tanto mais existe para eles a possibilidade de elevar na sociedade o valor social, ou, mais precisamente, a reputação de seus membros (HONNETH, 2003:207-208).
}

Fraser, entretanto, propõe um modelo bidimensional, une os paradigmas de reconhecimento e redistribuição para enfrentar a injustiça social para o alcance de uma sociedade em que todos tenham uma participação paritária. Esse modelo é cunhado pela autora como um modelo de status que visa a uma participação paritária. A autora, ao dialogar com a teoria do reconhecimento proposta por Honneth, critica a ideia de que o reconhecimento, onde os problemas estão relacionados à dignidade humana e à identidade, deve substituir a redistribuição que é calcada na defesa da provisão de direitos e bens de maneira equânime entre todos (FRASER, 2002, 2007; FRASER; HONNETH, 2003). Para Fraser, o paradigma da redistribuição não se resume a políticas que tenham como objetivo a classe social, como o liberalismo, a democracia social ou o socialismo, mas também outras formas de luta como o feminismo e o antirracismo, "que olham para a transformação socioeconômica ou reformas 
como uma solução para as injustiças de gênero e etnicorraciais" (FRASER; HONNETH, 2003:12, tradução nossa).

O paradigma do reconhecimento, na concepção de Fraser, pode não envolver somente a questão de valorizar identidades injustamente desvalorizadas, como o feminismo cultural, o nacionalismo cultural dos negros ou as políticas de identidade dos homossexuais, por exemplo. O reconhecimento também envolve tendências "desconstrutivas, como as políticas queer, políticas raciais críticas e o feminismo desconstrutivo que rejeita o essencialismo das políticas de identidade tradicionais" (FRASER; HONNETH, 2003:12, traduçãa nossa).

No entanto, Fraser discute se redistribuição e reconhecimento podem ser reduzidos a uma única dimensão. Afirma que nem todo não reconhecimento é resultado de má distribuição ou da má distribuição agregada à discriminação legal. Para Fraser, o reconhecimento não é baseado somente em função da classe social, cita como exemplo, o banqueiro negro de Wall Street que não consegue pegar um táxi. O banqueiro, como exemplo em questão, possui elevados recursos financeiros, mas é ignorado pelo taxista em razão do não reconhecimento como um potencial passageiro. Nesse caso, a injustiça não tem relação com a má distribuição, mas sim com a falta de respeito com a população negra, defende Fraser (FRASER, 2000). Muito além da questão identitária, Fraser defende que o reconhecimento deve ser tratado como um assunto de justiça. Defende que a justiça social, objeto de ação do reconhecimento e da redistribuição, deve ir além da distribuição de direitos e bens. A justiça social deve examinar os padrões institucionalizados de valoração cultural (FRASER, 2007). Para se estabelecer justiça social deve se questionar se os padrões instituídos impedem a participação plena do indivíduo ou grupos na vida social.

\footnotetext{
Isto significa examinar padrões de valores culturais institucionalizados e seus efeitos sobre a posição relativa dos atores sociais. Quando padrões constituem atores como pares, capazes de participar um com outro na vida social, nós podemos chamar de reconhecimento recíproco e status de igualdade. Quando, em contraste, padrões de valores culturais institucionalizados constituem alguns atores como inferiores, ou simplesmente tornando-os invisíveis, sendo menos do que parceiros nas interações sociais, chamamos isso de não reconhecimento e status de subordinação (FRASER; HONNETH, 2003:29, tradução nossa).
}

O não reconhecimento é errado não porque o outro não reconhece alguém como sujeito, como defende Honneth na controvérsia com Fraser, mas porque é uma forma de 
subordinação institucionalizada, violando a justiça (FRASER, 2007). Por isso Fraser entende o reconhecimento como uma questão de justiça porque significa que foi negada a indivíduos e grupos a condição de parceiros integrais na interação social em razão dos padrões institucionalizados de valoração cultural, de cujas construções eles não participaram em condições de igualdade, e os quais depreciam as suas características distintivas ou as características distintivas que lhes são atribuídas (FRASER, 2007). Fraser evita o sectarismo e o essencialismo de uma identidade singular trazidos pelo padrão de reconhecimento defendido por Honneth (2003).

As vantagens de tratar o reconhecimento como uma questão de justiça é que o modelo de status proposto por Fraser não visa a uma boa vida, mas apela para uma concepção de justiça que pode e deve ser aceita por aqueles que tenham divergentes concepções da boa vida; focaliza o equívoco nas relações sociais e políticas; e não na psicologia individual ou interpessoal. Fraser assegura que quando o não reconhecimento é identificado com distorções internas na estrutura da autoconsciência do oprimido, basta apenas um pequeno passo para culpar a vítima. Por exemplo, imputar um dano psíquico àqueles submetidos ao racismo parece agravar ainda mais a sua situação. É muito comum as pessoas vítimas de racismo, ao reconhecerem a sua situação de fragilidade, serem apontadas com um distúrbio interno que o racismo ou o preconceito está nela (FRASER, 2007). A vitimização representa o processo em que a pessoa enxerga algo que não existe; como se ela não tivesse a autoconsciência de sua opressão. No modelo padrão de reconhecimento, defendido por Honneth, para superar o não reconhecimento os opressores devem monitorar as suas crenças. Já para o modelo de status de Fraser, pode-se verificar o não reconhecimento pelo fato de indivíduos serem membros integrais ou não da sociedade; de não exercerem uma participação paritária.

Fraser procura esclarecer o conceito de participação paritária. Argumenta que é muito comum, quando se discute participação paritária, as pessoas entenderem que deve haver uma igualdade numérica, 50\%, como fizeram na participação política feminina na França, onde há uma demanda para que as mulheres ocupem metade das cadeiras no Parlamento. Paridade, para Fraser, significa a condição de par, de estar em igualdade de condição com os demais, de estar partindo do mesmo lugar. Cabe aos membros da sociedade escolherem se e quando 
devem participar de uma dada atividade ou interação; o que deve ser garantido é a possibilidade de paridade, defende Fraser (FRASER, 2007).

Fraser, ainda rebatendo a teoria de Honneth, polemiza os princípios de respeito e estima. A autora esclarece que respeito se tem com todas as pessoas em virtude de uma humanidade compartilhada. O respeito é universal. Estima, ao contrário, representa um aspecto muito individual. O sujeito tem estima por alguém em função das características específicas, conquistas ou contribuições de uma pessoa. Dessa maneira, enquanto respeitar a todos de modo igual é perfeitamente aceitável, a imposição de estimar a todos de modo igual é um contrassenso (FRASER, 2007). Para Honneth, todas as pessoas merecem estima social. Fraser, ao contrário, afirma que se espera respeito, mas amor e amizade constitui uma imposição que não faz sentido; no entanto, todos têm direito de buscar a estima social, desde que tenham igualdade de oportunidades para tal.

Fraser discute que teóricos como Honneth não conseguem explicar por que não são todas as diferenças sociais que geram reivindicações por reconhecimento. Cita um exemplo do porquê os homens, os heterossexuais e os brancos geralmente evitam o reconhecimento de suas particularidades - esses são atributos considerados padrões para valores culturais dominantes. Fraser defende que sua teoria contextualiza e vê de modo pragmático as reivindicações por reconhecimento, pois entende que as necessidades por reconhecimento de atores subordinados diferem das dos atores dominantes, e apenas reivindicações que promovem a paridade de participação são moralmente justificadas (FRASER, 2007).

Assim, Fraser defende que a justiça pode requerer o reconhecimento das particularidades em alguns casos, tudo dependendo do que as pessoas não reconhecidas necessitam de forma a serem capazes de participar da vida social. As pessoas podem, por exemplo, precisar de ser aliviadas da excessiva distinção atribuída ou construída. Trazendo um exemplo do nosso contexto nacional, os negros no Brasil têm um histórico de vitimação por perjúrios e de estereotipação em razão da cor da sua pele, de sua estética, de seu corpo e de suas origens. Vem daí a luta pelo reconhecimento da sua integridade, da sua visibilidade e da sua participação social, a despeito de suas diferenças. Como já salientamos para Fraser o fazer justiça social seria entender que as pessoas necessitam que as suas particularidades sejam 
reconhecidas. Os negros brasileiros lutam pelo reconhecimento de sua história e da influência da cultura de matriz africana na identidade brasileira.

Na nossa concepção, os fundamentos de políticas de promoção da igualdade racial para a população negra repousam na ideia de uma justiça social nos moldes defendidos por Fraser. O conceito de redistribuição de Fraser presume que a injustiça socioeconômica tem raízes na estrutura econômica da sociedade. Os sujeitos podem constituir classes definidas economicamente ou grupos minoritários. A noção de redistribuição trata as diferenças como resultados construídos socialmente a partir de uma economia política injusta.

Fraser fala em remédios para os danos causados pelo não reconhecimento e pela não redistribuição, mas não aponta precisamente quais são os caminhos a serem tomados. Entretanto, explora como as reivindicações por reconhecimento e por políticas redistributivas devem ser julgadas. Primeiramente, defende a autora, a paridade de participação deve nortear toda e qualquer reivindicação, seja ela por reconhecimento ou por políticas redistributivas. Fraser enfatiza que aqueles que reivindicam reconhecimento e redistribuição devem mostrar que os arranjos atuais os impedem de participar em condição de igualdade com os outros na vida social; devem mostrar que os arranjos econômicos existentes lhes negam as necessárias condições objetivas para a paridade participativa quando se tratar de reivindicação redistributiva; ao reivindicar reconhecimento devem mostrar que os padrões institucionalizados de valoração cultural lhes negam as condições intersubjetivas necessárias; os reivindicantes do reconhecimento e de redistribuição devem mostrar que as mudanças sociais que eles perseguem irão, de fato, promover a paridade de participação; os postulantes de ações redistributivas devem mostrar que as reformas econômicas que eles defendem fornecerão as condições objetivas para a participação plena daqueles para quem elas são negadas atualmente; devem mostrar que as mudanças institucionais socioculturais que eles perseguem fornecerão as condições intersubjetivas necessárias ao reivindicar reconhecimento.

Sem nos aprofundarmos mais ainda na discussão teórica entre Fraser e Honneth - pois compartilhamos com Pinto (2008) de que a controvérsia entre esses dois autores é uma falsa antítese porque há uma afinidade da teoria construída por Fraser e por Honneth que se 
aproxima das nossas convicções e daquilo que compreendemos como o processo de luta do movimento social negro -, fechamos com as considerações de Fraser dos remédios propostos que estão sob a mão do Estado e com as reivindicações de reconhecimento e de redistribuição do movimento social negro. Essas considerações estão fundadas sob alguns paradigmas como a bidimensionalidade do conceito de raça e os padrões de valores culturais.

\begin{abstract}
Raça tem claramente uma divisão social bidimensional, status e classe. Originada simultaneamente na estrutura econômica e na condição da sociedade capitalista, injustiça racial inclui tanto a má distribuição e o não reconhecimento (...). Na economia, raça organiza as divisões estruturais entre trabalhos remunerado manual e não manual, por outro lado, entre a força de trabalho explorada e supérflua. Como resultado, a estrutura econômica gera formas racialmente específicas de má distribuição (...). Estas injustiças distributivas não têm como serem solucionadas apenas pelas políticas de redistribuição (FRASER; HONNETH, 2003:22-23, tradução nossa).

(...)

Padrões eurocêntricos de valores culturais privilegiam traços associados à branquitude, enquanto estigmatizam tudo que é codificado como negro, pardo e amarelo - paradigmaticamente, mas não apenas - pessoas de cor (...). Perversamente institucionalizados, normas eurocêntricas geram formas racialmente específicas de posições subordinadas, incluindo estigmatização e agressão física; desvalorização cultural, exclusão social e marginalização política, assédio e desprezo na vida cotidiana; e a negação de direitos e proteções iguais para o exercício da cidadania. Esses danos profundos em razão do não reconhecimento não podem ser solucionados somente pelas políticas de reconhecimento (FRASER; HONNETH, 2003:24-25, tradução nossa).
\end{abstract}

\title{
Fraser complementa:
}

\begin{abstract}
Nenhuma dimensão de racismo é completamente um efeito indireto de outra. As dimensões distributivas e de reconhecimento interagem uma com a outra. Mas má distribuição racista não é simplesmente um subproduto da posição hierárquica; muito menos o não reconhecimento racista é completamente um subproduto da estrutura econômica. Em vez disso, cada dimensão tem alguma independência relativa entre um e outro. A superação das injustiças do racismo requer ambos redistribuição e reconhecimento. Nenhum sozinho é suficiente (FRASER; HONNETH, 2003:24-25, tradução nossa).
\end{abstract}

Acreditamos que o combate ao racismo seja a motivação dos objetivos das políticas de promoção da igualdade racial, havendo uma intenção de propiciar igualdade de oportunidades aos negros e consequentemente elevá-los nos níveis sociais e econômicos. Se entendermos o racismo como raiz de toda ação de discriminação e de preconceito racial que leva consequentemente a população negra a não exercer plenamente a sua cidadania e, a não permitir uma paridade de participação nos termos defendidos por Fraser, conseguiremos articular as políticas de promoção da igualdade racial à desigualdade racial e social no Brasil. Para sermos mais exatos, se os negros compõem o estrato mais pobre da população brasileira, as ações que visam a focalizar as políticas públicas nos recortes raciais irão 
diretamente impactar nos arranjos sociais e econômicos da população negra. Isso traz um desafio para o movimento social negro e para aqueles que defendem as suas reivindicações na disputa por políticas públicas voltadas à população negra. Elas não se restringem apenas à inserção da população negra na universidade, mas a uma interação sistêmica em que haja a atuação do Estado. As políticas universalistas são para todos, as políticas focalizadas no caráter das políticas de promoção da igualdade racial, quando são para os negros, devem ser especificadas para essa população. Feres Júnior (2006) problematiza a ideia de que políticas de caráter universal daria conta de resolver de forma razoável as desigualdades sociais e raciais. Para o autor, mesmo o Estado de Bem-Estar Social, que é comumente associado a políticas públicas universais, já operava com políticas focalizadas. A focalização das políticas públicas era denominada de discriminação positiva e identificava onde estavam os problemas e estabelecia um fluxo de recursos e ações diretamente para atendê-los. Vemos políticas dessa vertente quando há ações voltadas para habitação popular, seguro desemprego, proteção para setores energéticos, grandes investimentos públicos em áreas carentes, etc. No combate ao racismo, as políticas públicas poderiam ser mais incisivas, como atesta o autor ao descrever o que motivou a implantação das políticas de ação afirmativa na década de 1960 nos Estados Unidos:

\footnotetext{
Basta que concordemos com o diagnóstico de que o racismo, ou a discriminação racial, existe e opera produzindo um grau razoável de desigualdade; de que as políticas públicas de natureza exclusivamente universal não têm contribuído efetivamente para diminuir essas desigualdades; e que a legislação antidiscriminação, de natureza meramente reativa, não é eficaz (...) que medidas especiais de promoção daqueles que sofrem tal discriminação podem ser necessárias (FERES JÚNIOR, 2006:50).
}

O ponto central de uma estratégia de focalizar políticas públicas para a população é que eleva a representação da população negra em espaços sociais e econômicos em que estava secularmente excluída; trabalha a sua autoestima; constrói, resgata a sua história, raízes e cultura no imaginário brasileiro, dando rosto, cor e voz à cultura de matriz africana. Passa, então, por uma política de identidade silenciosa, conforme fazem refletir as duas falas a seguir.

A massa negra não consegue visualizar a luta antirracista. Ela não consegue ligar: ser contra o racismo, em que a beneficia? Com a ação afirmativa ela passa a entender: é vaga na universidade, é vaga no shopping center, onde o cara não te emprega. Assim ela entende, porque você está mostrando um caminho concreto (Entrevista de Ivair Augusto Alves dos Santos ao CPDOC - ALBERTI; PEREIRA, 2007:393). 
Outra reflexão de um dos dirigentes entrevistados para este estudo quanto aos dilemas da população negra na construção de sua identidade individual e coletiva:

\begin{abstract}
Grande parte do que a gente faz, da política que a gente faz, são para pessoas que querem melhorar de vida, não há uma grande preocupação com a coletividade, cada um procura de que maneira vai se dar bem na vida. Então, por mais que a gente quisesse, gostaria que tivesse uma consciência de elite negra, a gente não caminha para isso, há uma disputa individual muitíssimo forte entre os próprios negros para saber quem é quem nesse processo. Então a gente luta contra essa falta de consciência da comunidade negra; luta contra aqueles que querem casar a gente com a luta contra a pobreza, cada vez que a gente consegue avançar um pouco, eles amarram em você uma correntinha para prender o seu pé em outro problema que você não pode resolver porque só conseguem entender o negro como pobre, então o problema é acabar com a pobreza; é enriquecer o cara. Você não consegue convencer as pessoas que viveram a vinda inteira como não negros e são negros e vivem naquele dilema: o que eu vou fazer, para onde eu caminho, eu nunca tive problema, etc. e tal. (Dirigente 5)
\end{abstract}

Vimos que a atuação do movimento social negro foi imprescindível para o reconhecimento das suas reivindicações pelo Estado. O movimento social negro é coeso ao afirmar que a luta está além das cotas, que é um percentual arbitrário. O que o movimento social negro defende é a instituição de ações afirmativas na sociedade brasileira que favoreçam a população negra (ALBERTI; PEREIRA, 2007). As ações afirmativas passam por um processo educacional, de reconhecer o outro, no caso a população negra, como igual em direitos e em potencial. Fazer ação afirmativa no Brasil significaria fazer a coisa certa da forma certa. As ações afirmativas têm um caráter, primeiramente, de reconhecimento e de justiça distributiva nos princípios que defende Fraser. Como descrevemos anteriormente, a instituição de cotas não é uma novidade no Brasil e acreditamos que ela não acaba por si mesmo sem ter educado, sem ter contribuído para uma autoconsciência da população não negra e negra da necessidade de promover justiça aos negros brasileiros. O avanço se dá com a participação e o reconhecimento de todos da necessidade da inserção da população negra nos amplos espaços sociais. Sem cairmos na ineficiência reconhecida pelos Estados Unidos de que só o encorajamento não basta, como nos esclareceu anteriormente Gomes (2001), as políticas de promoção da igualdade racial poderiam ser estabelecidas com vinculação ao estabelecimento de metas estatísticas sobre a presença de negros em determinados segmentos, refletindo um avanço social com o autorreconhecimento e a valorização do que somos.

Em matéria educacional, o efeito poderia ser o reconhecimento pela população brasileira da influência e da participação do povo negro na construção socioeconômica do país. Um processo que se inicia com a destituição do 13 de maio como um marco para a população 
negra e reconhecimento de Zumbi dos Palmares como um herói nacional, tombando o dia 20 de novembro como uma data emblemática de reflexão, de denúncia e de celebração da luta do movimento social negro. Abdias Nascimento e Elisa Nascimento expressam qual foi o cerne da luta do movimento social negro de 1930 até a década de 70, “o anseio da maior parte da comunidade negra em reconstruir o seu passado coletivo para melhor erguer o seu presente e futuro" (NASCIMENTO; NASCIMENTO, 2000:204). No surgir da década de 1990 a pauta de reivindicação do movimento social negro se amplia para o estabelecimento de uma legítima democracia que requer a elevação do nível de vida da população negra, tendo como bandeira de luta políticas de ações afirmativas e cuja dimensão mais polêmica, as cotas raciais, se fazem insurgir num cenário de amplo debate que desnuda as feições do racismo à brasileira.

Sendo para Honneth o reconhecimento uma relação intersubjetiva, de forma que não haja deformação ou depreciação da identidade do indivíduo ou de grupos, podemos entender que essa articulação se aproxima do reconhecimento da cultura afro-brasileira atualmente. Um reconhecimento falso, pois é sustentado pelo ideal de democracia racial que nega a particularidade da população negra, o que a impossibilita de participar de forma paritária da vida em sociedade. Podemos observar isso pela apropriação cultural e pela invisibilidade da população negra em espaços sociais e econômicos privilegiados. O reconhecimento é falso porque é apenas discursivo, pois o corpo, a estética, o pensamento e a sinergia negra não são visíveis, não se manifestam espacialmente.

A construção da ideia de relações raciais horizontais por Telles (2003), ou relações moles como discute Sansone (1996), nos traz elementos de como esse reconhecimento falso se dá no cotidiano brasileiro. Além disso, essas relações podem ser aplicadas dentro da teoria de reconhecimento de Honneth. Telles considera que as relações raciais no Brasil podem ser identificadas como relações horizontais e relações verticais. Relações raciais horizontais referem-se à sociabilidade interracial, sobretudo entre pessoas de mesma classe social. Relações raciais verticais são aquelas entre diferentes classes sociais, que implicam relações de poder socioeconômico (TELLES, 2003). Os conceitos de Sansone (1996) identificam as relações raciais brasileiras como áreas duras e áreas moles. Áreas duras nas relações raciais são 1) o trabalho, e em particular a procura do trabalho; 2) o mercado matrimonial e da 
paquera; 3) os contatos com a polícia. As áreas moles são todos aqueles espaços no qual ser negro não dificulta e pode às vezes até dar prestígio (SANSONE, 1996). O autor enumera o lazer, o samba, o carnaval, a igreja católica, a igreja evangélica, os espaços negros definidos e explícitos, como o bloco-afro, a batucada, o candomblé, a capoeira.

Como há uma ideia de que ser negro não dificulta as relações horizontais ou moles, cria-se a falsa noção de que o reconhecimento do negro é pleno em todas as relações de poder e sociais. Telles (2003) questiona que até o momento, o crescente reconhecimento do racismo pela sociedade brasileira não parece ter reduzido o comportamento discriminatório. $\mathrm{O}$ autor enfatiza que esse reconhecimento não é entendido por que ações de uma pessoa podem ser discriminatórias. "O reconhecimento, por si só, dificilmente modificará de forma significativa os padrões bem enraizados de comportamento social" (TELLES, 2003:310).

No nosso ponto de vista, para avançarmos além das relações horizontais ou moles, precisaríamos lançar mão do modelo de status proposto por Fraser, em que a política de reconhecimento objetiva superar a subordinação, fazendo do sujeito falsamente reconhecido um membro integral da sociedade, capaz de participar com os outros membros em pé de igualdade (FRASER, 2007). Como dissemos anteriormente, o objetivo maior de Fraser é defender o caráter bidimensional do reconhecimento e da redistribuição, trabalhando a questão cultural e econômica desses dois paradigmas, sem abrir mão das especificidades de cada uma dessas duas vertentes.

Embora o caráter residual das políticas de promoção da igualdade racial seja melhor explorado na seção seguinte, alavancada pelas análises conceituais e históricas aqui realizadas, torna-se possível afirmar que há um reconhecimento da questão racial no governo federal, mas por outro lado os desafios para a implementação dessas políticas esbarram em obstáculos que estão organizados em perspectivas ideológicas muito fortes. $\mathrm{O}$ reconhecimento da população negra em sua plenitude como sujeito de direitos a ser inserida em um projeto de desenvolvimento social e econômico do Brasil é uma estratégia que requer políticas redistributiva e de reconhecimento. 
Se, por um lado, há ações que têm no seu fim a política de igualdade racial, paira no inconsciente coletivo a ausência de reconhecimento do racismo no Brasil e de entendimento do verdadeiro propósito das políticas de promoção da igualdade racial sufocadas nas manifestações de temas de enfrentamento da pobreza. Esse déficit de reconhecimento da legitimidade das iniciativas de combate ao racismo se reflete na escassez de recursos e na baixa sensibilização do corpo técnico e político ao formular e implementar políticas de promoção da igualdade racial, o que passaremos a ver agora.

\subsection{Capacidade técnico-institucional e a responsabilidade compartilhada}

Nesta seção, analisamos a baixa capacidade técnica e institucional por meio de dados de sistemas de gestão e de seus instrumentos operacionais. Entendemos que as políticas públicas de promoção da igualdade racial carecem de apoio político e técnico para a sua efetiva execução. $\mathrm{O}$ orçamento destinado e a sua execução não são expressivos e atingem pouco o seu público alvo. O tema desigualdade racial surge nos Planos Plurianuais-PPA de 2004-2007 e de 2008-2011. Entretanto, no planejamento governamental, a questão racial não está desenhada como um problema para atacar as suas causas. Um planejamento estruturado em problemas e causas levaria aos efeitos do problema para subsidiar a formulação de políticas públicas universais, focalizadas e transversais de combate à desigualdade racial (SILVA et al, 2011).

Ao analisar a execução do Orçamento da Igualdade Racial no período do Plano Plurianual 2008-2011 (Tabela 2), observa-se que há uma oscilação grande na execução dos programas. O que caracteriza uma baixa capacidade técnica e institucional da gestão desses programas.

Destacam-se os programas Comunidades Tradicionais, cuja execução orçamentária foi de 100\% em 2008 e zero em 2010; o Brasil Quilombola, que teve, nos dois primeiros anos do ciclo do PPA 2008-2011, execução menor que 22\%, ampliando para mais de 60\% nos dois últimos anos do ciclo do PPA. O programa Saneamento Rural, ao longo dos quatro anos de execução do PPA, teve parcas execuções orçamentárias, a exceção reserva-se para o primeiro ano, 98\%. A execução orçamentária do programa Cultura Afro-Brasileira, no ciclo 2008-2011, também não foi eficaz, tendo uma média de 45\%, com dois grandes extremos 
em 2008, 14,6\%, e em 2009, 82\%. O programa Educação para a Diversidade e Cidadania teve uma média de $34 \%$ de execução orçamentária. Ao longo do período analisado, grandes oscilações são observadas na execução orçamentária dos programas Assistência Técnica e Extensão Rural na Agricultura Familiar e Promoção de Políticas Afirmativas para Igualdade Racial conforme descrito na Tabela $1^{23}$.

\footnotetext{
${ }^{23}$ Fonte Plano Plurianual 2008-2011:
}

Cultura Afro-Brasileira - Objetivo: proteger e promover a cultura e o patrimônio afro-brasileiro. Públicoalvo: Sociedade em geral, com prioridade para os/as afro-brasileiros/as.

Comunidades Tradicionais - Objetivo: contribuir para a melhoria da qualidade de vida dos integrantes de comunidades tradicionais, dinamizando as atividades produtivas e incentivando o uso sustentável dos ambientes que ocupam, por meio da valorização da cultura e das formas de organização social. Público-alvo: comunidades e entidades representativas de populações tradicionais.

Brasil Quilombola - Objetivo: Assegurar às comunidades remanescentes de quilombos a propriedade de suas terras, desenvolvimento econômico sustentável, infra-estrutura adequada para suas atividades, melhoria das condições de vida, preservação do Patrimônio Cultural Material e Imaterial e capacidade para exercer controle efetivo sobre as políticas públicas que lhes são destinadas. Público-alvo: População de comunidades - rurais ou urbanas - remanescentes de quilombos.

Educação para a diversidade e cidadania - Objetivo: Reduzir as desigualdades étnico-racial, de gênero, de orientação sexual, geracional, regional e cultural no espaço escolar. Público-alvo: Alunos de todas as idades, seus familiares e os profissionais da educação.

Saneamento Rural - Objetivo: ampliar a cobertura e melhorar a qualidade dos serviços de saneamento ambiental em áreas rurais. Público-alvo: população rural dispersa, residente em assentamentos da reforma agrária e em localidades de até 2.500 habitantes e as minorias étnico-raciais como quilombolas, população indígena e outros povos da floresta.

Assistência Técnica e Extensão Rural na Agricultura Familiar - Objetivo: disciplinar, ampliar, organizar e qualificar a prestação dos serviços de Ater para os agricultores familiares e empreendedores familiares rurais. Público-alvo: agricultores familiares, empreendedores familiares rurais (conforme previsto na Lei $n^{\circ}$ 11.326/06), comunidades tradicionais, beneficiários do Programa Nacional de Reforma Agrária e agentes de Ater.

Promoção de políticas afirmativas para igualdade racial - Objetivo: reduzir as desigualdades raciais e promover uma cultura não-discriminatória, de forma a assegurar à população - independentemente de sua cor ou raça - o exercício pleno de sua cidadania e melhores condições de vida. População-alvo: grupos étnica e racialmente discriminados, com ênfase na população negra 
Tabela 2 - Percentual de execução orçamentária dos programas do Orçamento da Igualdade Racial: 2008-2011

\begin{tabular}{lrrrr}
\hline Programas & 2008 & 2009 & 2010 & 2011 \\
Cultura afro-brasileira & 14,6 & 82,0 & 47,8 & 36,4 \\
Comunidades tradicionais & 100,0 & 10,3 & 0 & 91,3 \\
Brasil quilombola & 15,5 & 21,6 & 61,5 & 61,0 \\
Educação para a diversidade e cidadania & 36,4 & 16,9 & 47,9 & 34,8 \\
Saneamento rural & 98,3 & 0,1 & 0,1 & 4,5 \\
Assistência técnica e extensão rural na & 85,7 & 57,4 & 56,0 & 97,8 \\
agricultura familiar & & & 54,0 & 15,2 \\
Promoção de políticas afirmativas para & & 59,8 & &
\end{tabular}

Os programas apresentados na Tabela 2 são gerenciados por diversos órgãos do Poder Executivo Federal. Não estão concentrados apenas nas estruturas da SEPPIR ou na Fundação Cultural Palmares do Ministério da Cultura. A execução orçamentária dos programas da igualdade racial reflete o alcance das metas físicas dos programas, conforme descrito na Tabela A12, Anexo A.

Percentualmente, vê-se, pela Tabela 3, que há grandes variações no alcance dos resultados pretendidos pelos programas. Qualquer esforço para se buscar algum padrão de análise no alcance das metas físicas desses programas seria infrutífero. Para exemplificar, analisam-se as metas previstas e alcançadas pelos programas Saneamento Rural e Extensão Rural na Agricultura Familiar. Observa-se que o programa Saneamento Rural em 2009 alcançou mais de $100 \%$ da sua meta prevista, entretanto nos outros três anos teve um resultado precário. O alcance das metas previstas pelo programa Assistência Técnica e Extensão Rural na Agricultura Familiar foi harmônico, porém, em 2010, teve um parco resultado. A sua meta realizada foi de $17 \%$ da meta prevista. Isso nos leva a inferir que não houve autorização para utilizar o orçamento aprovado ou dificuldade de gerir o orçamento quando autorizado um reflexo do dimensionamento dos recursos humanos, das habilidades e talentos da força de trabalho instalada e do baixo apoio político para esses programas. 
Tabela 3 - Percentual de alcance das metas previstas dos programas do Orçamento da Igualdade Racial: 2008-2011

\begin{tabular}{lcccc}
\hline Programas & 2008 & 2009 & 2010 & 2011 \\
Cultura afro-brasileira & 19 & 51 & 105 & 64 \\
Comunidades tradicionais & 44 & 25 & 26 & 51 \\
Brasil quilombola & 153 & 66 & 53 & 9 \\
Educação para a diversidade e cidadania & 98 & 18 & 64 & 33 \\
Saneamento rural & 12 & 114 & 2 & 2 \\
$\begin{array}{l}\text { Assistência técnica e extensão rural na } \\
\text { agricultura familiar }\end{array}$ & 65 & 98 & 17 & 87 \\
$\begin{array}{l}\text { Promoção de políticas afirmativas para } \\
\text { igualdade racial }\end{array}$ & 9 & 34 & 2 & 20 \\
\hline Fonte: SPI/MP, em 12/09/12. Elaboração própria, 2014 & & & &
\end{tabular}

Comparativamente a órgãos similares, os instrumentos de gestão da SEPPIR e da FCP são, de forma geral, quantitativamente inferiores. Dados de $2010^{24}$ demonstram que a SEPPIR possui 42 cargos em comissão (que são cargos de livre nomeação e exoneração), frente a 161 da Secretaria de Direitos Humanos-SDH e 45 da Secretaria de Políticas para as Mulheres-SPM. A força de trabalho da SEPPIR é composta por 64 pessoas, a SDH possui 67 e a SPM, 93.

Ao comparar a FCP em relação a alguns de seus pares do Ministério da Cultura, sistema Minc, temos o seguinte quadro: a FCP possui 41 pessoas na sua força de trabalho, a Fundação Casa Rui Barbosa-FCRB tem 104 servidores, a Fundação Biblioteca Nacional-FBN, 461, e a Agência Nacional de Cinema-Ancine, 207. Cargos comissionados, a FCP possui 53, FCRB, 26, FBN, 50, e a Ancine tem 129.

Esses dados demonstram que os órgãos governamentais da igualdade racial, geralmente, quando comparados com os seus similares, possuem menor força de trabalho e escassos recursos para a composição de quadros gerenciais, pois contam com uma estrutura de cargos em comissão mais enxuta.

No período de execução do PPA 2008-2011, a comparação dos orçamentos autorizados desses órgãos governamentais demonstra a discrepância de distribuição de recursos

\footnotetext{
${ }^{24}$ Dados obtidos da Síntese Temática elaborado pela Secretaria de Gestão Pública do Ministério do Planejamento, Orçamento e Gestão http://www.planejamento.gov.br/secretaria.asp?cat=297\&sec=6 acessados em 23/08/12.
} 
orçamentários e, consequentemente, a liberação de limite para a sua execução. Esse aspecto é analisado nos próximos parágrafos desta seção.

O conjunto das Tabelas 4, 5 e 6 demonstra que, em relação a seus pares, a FCP tem uma desvantagem orçamentária. Comparativamente, no período de 2008 a 2011, o orçamento autorizado apresenta uma diferença orçamentária a maior entre a FCP e a FBN, 71\% é diferença média ${ }^{25}$ entre essas duas instituições no período de 2008 a 2011, distintamente da FCRB, onde a diferença fica em torno de 12\%, em média. Em relação à Ancine, a diferença média é de $63 \%$. Na execução do orçamento, as diferenças aumentam, entre a FCP e a FCRB, $46 \%$ em média. Quanto à diferença entre a FCP-FBN e a FCP-Ancine é, em média, de $80 \%$ e 77\% respectivamente. Todos os percentuais se referem ao período de 2008 a 2011.

Tabela 4 - Orçamento autorizado de órgãos do sistema Minc: 2008-2011 (R\$)

\begin{tabular}{lcccc}
\hline \multicolumn{1}{c}{ Órgãos } & 2008 & 2009 & 2010 & 2011 \\
FCP & $35.693 .807,00$ & $20.934 .237,00$ & $22.066 .164,00$ & $28.981 .876,00$ \\
FCRB & $25.662 .952,00$ & $30.179 .861,00$ & $31.602 .831,00$ & $40.228 .288,00$ \\
FBN & $91.174 .847,00$ & $88.126 .784,00$ & $89.528 .971,00$ & $95.305 .051,00$ \\
ANCINE & $55.993 .380,00$ & $67.994 .981,00$ & $84.316 .009,00$ & $105.038 .790,00$ \\
\hline
\end{tabular}

Fonte: SIGA-Brasil, 23/08/12. Elaboração própria, 2014

FCP = Fundação Cultural Palmares; FCRB = Fundação Casa Rui Barbosa; FBN = Fundação Biblioteca Nacional e ANCINE = Agência Nacional de Cinema

Tabela 5 - Orçamento liquidado de órgãos do sistema Minc: 2008-2011 (R\$)

\begin{tabular}{ccccc}
\hline Órgãos & 2008 & 2009 & 2010 & 2011 \\
FCP & 11.783 .092 & 18.546 .057 & 15.470 .674 & $19.243 .435,00$ \\
FCRB & 24.922 .646 & 29.290 .827 & 30.795 .224 & $34.742 .717,00$ \\
FBN & 88.672 .010 & 83.790 .570 & 73.328 .622 & $78.120 .775,00$ \\
ANCINE & 52.771 .396 & 64.841 .869 & 76.698 .547 & $87.863 .782,00$ \\
\hline
\end{tabular}

Fonte: SIGA-Brasil, 23/08/12. Elaboração própria, 2014

FCP = Fundação Cultural Palmares; FCRB = Fundação Casa Rui Barbosa; FBN = Fundação Biblioteca Nacional e ANCINE = Agência Nacional de Cinema

\footnotetext{
${ }^{25} \mathrm{Na}$ comparação entre FCP e FBN, tomamos o total do orçamento da FBN e diminuímos pelo orçamento da FCP e dividimos pelo orçamento da FBN para encontrarmos a diferença. Fizemos esse exercício ano a ano. De posse do percentual ano a ano, achamos a média das diferenças orçamentárias no período de 2008 a 2011. Esse mesmo exercício fizemos na comparação FCP/FCRB e FCP/ANCINE.
} 
Tabela 6 - Percentual de execução orçamentária de órgãos do sistema Minc: 2008-2011 (R\$)

\begin{tabular}{ccccc}
\hline Órgãos & 2008 & 2009 & 2010 & 2011 \\
FCP & $33 \%$ & $89 \%$ & $70 \%$ & $66 \%$ \\
FCRB & $97 \%$ & $97 \%$ & $97 \%$ & $86 \%$ \\
FBN & $97 \%$ & $95 \%$ & $82 \%$ & $82 \%$ \\
ANCINE & $94 \%$ & $95 \%$ & $91 \%$ & $84 \%$ \\
Fonte: SIGA-Brasil, 23/08/12. Elaboração própria, 2014 \\
FCP = Fundação Cultural Palmares; FCRB = Fundação Casa Rui Barbosa; FBN = Fundação Biblioteca Nacional e ANCINE = Agência \\
Nacional de Cinema
\end{tabular}

A baixa execução orçamentária da FCP comparada aos outros órgãos do Sistema Minc, anteriormente descrito, reflete a carência de seus recursos de gestão e o escasso apoio político. A liberação de limite orçamentário-financeiro, ou seja, a autorização para se gastar o orçamento, requer, obrigatoriamente, decisão superior institucional, no caso do Sistema Minc, seria a Secretaria Executiva ou o Ministro da pasta.

A FCP possui uma atuação específica no setor cultural, o que justificaria ampliar o seu orçamento e o seu apoio institucional dentro do Ministério da Cultura. Seria, portanto, um órgão de referência quando o assunto fosse cultura de raízes africanas e da diáspora negra moderna em quaisquer áreas e segmentos culturais.

$\mathrm{Na}$ área de direitos humanos a SEPPIR, também, tem o menor orçamento comparativamente à SPM e SDH, conforme as Tabelas 7, 8 e 9. Durante a execução do PPA 2008-2011, o orçamento autorizado da SEPPIR teve uma diferença média de $20 \%$ em relação à SPM e de $72 \%$ em relação à SDH. Na execução orçamentária a diferença média subiu para 58\% e $82 \%$ entre SEPPIR-SPM e SEPPIR-SDH respectivamente ${ }^{26}$.

Tabela 7 - Orçamento autorizado dos órgãos de direitos da cidadania: 2008-2011 (R\$)

\begin{tabular}{ccccc}
\hline Órgãos & 2008 & 2009 & 2010 & 2011 \\
SEPPIR & $37.489 .860,00$ & $40.582 .689,00$ & $69.825 .671,00$ & $95.632 .848,00$ \\
SPM & $61.444 .971,00$ & $77.014 .796,00$ & $89.715 .636,00$ & $109.028 .488,00$ \\
SDH & $166.795 .664,00$ & $191.201 .583,00$ & $239.294 .197,00$ & $243.768 .645,00$ \\
\hline
\end{tabular}

Fonte: SIGA-Brasil, 23/08/12. Elaboração própria, 2014

SEPPIR = Secretaria de Políticas de Promoção da Igualdade Racial; SPM = Secretaria de Política para as Mulheres; SDH = Secretaria de Direitos Humanos

${ }^{26}$ Ver a explicação do procedimento na nota de rodapé 36. 
Tabela 8 - Orçamento liquidado dos órgãos de direitos da cidadania: 2008-2011 (R\$)

\begin{tabular}{ccccc}
\hline Órgãos & 2008 & 2009 & 2010 & 2011 \\
SEPPIR & $24.524 .761,00$ & $26.287 .376,00$ & $42.633 .769,00$ & $24.268 .259,00$ \\
SPM & $55.900 .616,00$ & $73.770 .422,00$ & $75.849 .029,00$ & $78.069 .497,00$ \\
SDH & $132.138 .127,00$ & $163.168 .655,00$ & $177.115 .187,00$ & $163.825 .485,00$ \\
\hline
\end{tabular}

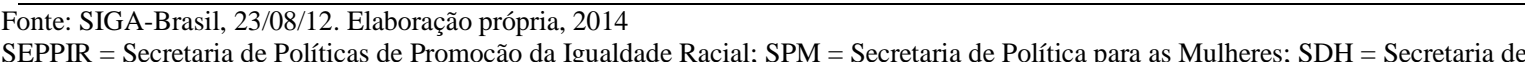
Direitos Humanos

Tabela 9 - Percentual da execução orçamentária dos órgãos de direitos da cidadania: 20082011

\begin{tabular}{|c|c|c|c|c|}
\hline Órgãos & 2008 & 2009 & 2010 & 2011 \\
\hline SEPPIR & $65 \%$ & $65 \%$ & $61 \%$ & $25 \%$ \\
\hline SPM & $91 \%$ & $96 \%$ & $85 \%$ & $72 \%$ \\
\hline $\mathrm{SDH}$ & $79 \%$ & $85 \%$ & $74 \%$ & $67 \%$ \\
\hline
\end{tabular}

O conjunto de Tabelas 7, 8 e 9 leva a concluir que há uma substancial diferença na distribuição de recursos orçamentários entre os órgãos de direitos da cidadania. Resta para a SEPPIR a menor parcela desse orçamento em relação aos seus pares. Diferentemente da FCP, para a SEPPIR, dada as suas finalidades, não se trata de ampliar o orçamento ou a estrutura dessa Secretaria, conforme discute o Ipea (SILVA et al, 2011) - o mesmo raciocínio cabe para a SDH e SPM. Trata-se de estender e compartilhar responsabilidades institucionais. Nesse mesmo estudo do Ipea chama a atenção que os formuladores e operadores de políticas públicas possuem uma percepção que cabe à SEPPIR o desafio de promover a equidade racial. Isso leva os órgãos governamentais a se omitirem dessa responsabilidade. Trazemos a fala de Ivanir dos $\operatorname{Santos}^{27}$, representante do movimento social negro, para expressar que não estamos descolados de uma análise semelhante à da sociedade civil em relação ao aparelho do Estado.

\begin{abstract}
A Seppir, da lógica do Estado, é uma possibilidade concreta. Embora eu tenha defendido outro modelo. Eu defendi a transversalidade. Não por conta do pessoal da Seppir, mas por conta do que o Estado faz quando cria a Seppir. Porque é natural você dizer assim: "Já está resolvido aquele canto". Eu seria favorável a que, no MEC, tivesse um secretário negro, numa daquelas secretarias, construindo uma política para a comunidade negra, e que, no Trabalho, tivesse alguém. Educação e trabalho são fundamentais para nós. Eu preferia isso. Todo mundo sabe que eu defendi esse modelo. O perigo da Seppir é o isolamento em que podem, no fundo, colocá-la. Se você não tem sensibilidade nos outros
\end{abstract}

\footnotetext{
${ }^{27}$ Entrevista ao CPDOC - Centro de Pesquisa e Documentação de História Contemporânea do Brasil da Fundação Getulio Vargas, no dia 01/12/2003.
} 
ministérios, a tendência é eles darem uma migalha aqui, outra ali, mas empurrar para a Seppir" (ALBERTI; PEREIRA, 2007:455-456).

Essa omissão leva os órgãos de direitos da cidadania a atuar na execução das políticas. As suas competências de articulação, formulação, planejamento e coordenação se dissipam frente à execução de micropolíticas demandadas pela sociedade civil que pressiona o Estado para fazer valer o compromisso declarado de tocar a agenda governamental.

O problema da desigualdade racial e a sua inserção nas políticas públicas devem-se dar transversalmente nas áreas sociais, de infraestrutura, de planejamento e econômica da administração pública. Um método de implantação de políticas públicas que podemos considerar como um desafio para as políticas públicas de promoção da igualdade racial. A implementação de políticas públicas transversais é um processo novo e obscuro para a maioria dos responsáveis por programas governamentais (SILVA et al, 2011). Agrega-se a isto, no caso das ações de promoção da igualdade racial, o imaginário da democracia racial, pois há gerentes governamentais que entendem que as políticas universais dariam conta de resolver todas as desigualdades, ainda, existentes.

E mais uma vez podemos explorar um pouco mais o perfil das pessoas que fazem a política pública no Estado, o quanto elas representam aqueles para quem trabalham ou se não representam, se estão sensíveis às demandas das minorias. Considerando a sua vasta experiência na administração pública, o Dirigente 5 entrevistado expressou a seguinte análise quando questionado sobre as pessoas que estão exercendo cargos de natureza política no Estado em relação a políticas de promoção da igualdade racial.

\footnotetext{
É pior...esses aí são os mais medrosos...eles estão ali para poder...durante um período...para poder executar uma política, poder trazer ganhos políticos para o seu Secretário, Ministro e ponto final. Se esse indivíduo percebe que essa política pode dar uma visibilidade boa para o senhor Ministro ele vai, mas como o risco é grande, ele não sabe muito bem como é essa área...ele passa a vida inteira sem conviver com isso, ele não entra nessa área (...) você levantou os vários problemas que tem e isso tudo deixa o cara paralisado. Como é que eu vou...o cara tem que ter muita convicção disso. Precisa ter passado por muitas experiências, ter uma bagagem cultural e entender esse processo, fazer uma ligação sobre o que se passa no mundo para entrar em uma dividida como essa.
}

Encontramos a mesma percepção dos respondentes desta pesquisa, a priorização das políticas universalistas frente às focalizadas com o seu consequente sepultamento que serão exploradas mais nos capítulos à frente. Trazemos a percepção de uma representante do 
movimento negro sobre a relação entre políticas universalistas e focalizadas à população negra para basear a nossa análise de alguns indicadores de igualdade racial.

\begin{abstract}
Eu acho esse debate extremamente estéril. Por quê? Porque acho que a população negra precisa de ambas as abordagens de políticas públicas. Você tem que ter políticas universalistas de fato, de excelente qualidade. Aquela escola pública que eu tive não era universalista; a grande massa da população, em 1950, estava na zona rural, e não tinha nem escola na zona rural e nas pequenas cidades. Então não era política universalista no meu tempo. Os adversários das cotas falam que era uma política fundada em valores universalistas e republicanos, não é isso? Eu falo o seguinte: precisamos de políticas universalistas de fato, desde a base, desde o jardim de infância. E precisamos também de políticas de ação afirmativa. Porque eu sempre digo o seguinte aos inimigos das cotas, gosto de ironizar: "Tudo bem, tem uma moçada ali naquele auditório que terminou o segundo grau e que está louca para pôr o pé na universidade, vai lá e fala para eles o seguinte: 'Nós não vamos fazer políticas de ação afirmativa, não. Nós vamos fazer políticas universalistas. A partir de agora as escolas públicas vão ser da melhor qualidade, e seus netos, ou bisnetos, entrarão nas universidades públicas sem precisar de ação afirmativa'. Vai lá e defende isso com essa turma. Se vocês derem conta, aplaudo vocês." (Entrevista de Diva Moreira ${ }^{28}$ ao CPDOC - ALBERTI; PEREIRA, 2007:421)
\end{abstract}

O alcance da igualdade racial não irá se fazer exclusivamente por meio de políticas voltadas à população negra descoladas de uma intervenção sistêmica nos problemas sociais e econômicos da realidade brasileira. Alguns indicadores divulgados recentemente nos apontam que houve uma evolução tanto nos grupos de brancos e negros, como no quadro geral quando se considera a população brasileira na sua totalidade. Entretanto, ao colocarmos uma lupa nos números percebemos que o tradicional gap entre os grupos se mantém. Vejamos os gráficos abaixo, produzidos de alguns indicadores da Tabelas A12, A13 e A14 (Anexo A).

\footnotetext{
${ }^{28}$ Entrevista ao CPDOC - Centro de Pesquisa e Documentação de História Contemporânea do Brasil da Fundação Getulio Vargas, no dia 29/03/2007. Diva Moreira nasceu na cidade de Bocaiúva (MG), em 8 de junho em 1946. Em 1950 mudou-se com a mãe para Belo Horizonte, onde foi criada. Formada em Comunicação Social pela Universidade Federal de Minas Gerais (UFMG), em 1970, e mestre em Ciência Política pela mesma universidade, em 1973, fez um curso de especialização no Instituto de Política Social da Universidade de Johns Hopkins, EUA, em 1993, e participou do Programa de Pós-Doutorado sobre Raça, Direitos e Recursos nas Américas no Instituto de Estudos Latino-Americanos da Universidade do Texas, entre 2001 e 2002. Foi técnica de pesquisa e planejamento da Fundação João Pinheiro, em Belo Horizonte, entre 1975 e 1988. Participou de vários movimentos sociais, alguns ligados à Igreja Católica, desde a década de 1960, e foi integrante do Partido Comunista Brasileiro entre 1968 e 1987, quando fundou a Casa Dandara Projeto de Cidadania do Povo Negro, uma entidade do movimento negro em Belo Horizonte. Foi presidente da Casa Dandara entre 1987 e 1995 e titular da Secretaria Municipal para Assuntos da Comunidade Negra de Belo Horizonte, criada por lei em 1998 e extinta em 2000. Entre 2003 e 2006 foi oficial de programa e ponto focal em raça e gênero do Programa das Nações Unidas para o Desenvolvimento, PNUD. É empreendedora social da Ashora e consultora independente na área da diversidade racial e de gênero.
} 
Gráfico 1 - Comparação entre brancos e negros da taxa de analfabetismo em 2004 e 2011

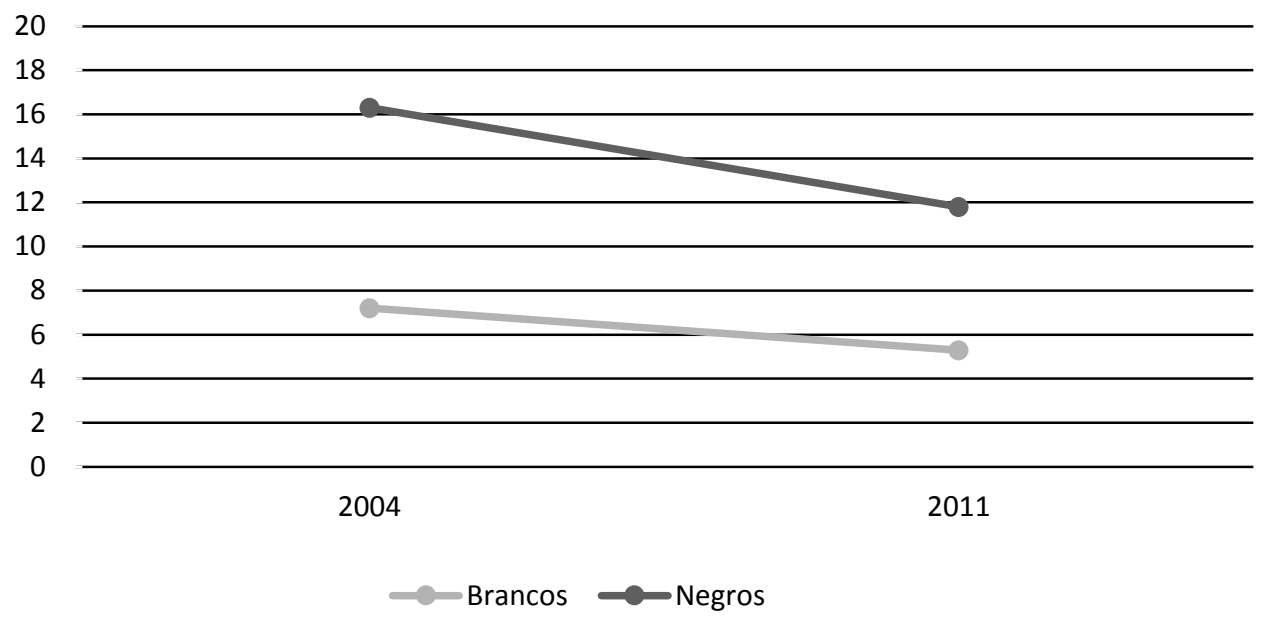

Fonte: Plano Mais Brasil PPA 2012-2015: agendas transversais - monitoramento participativo: ano base 2012/Ministério do Planejamento, Orçamento e Gestão - p. 29 - Elaboração própria, 2014

Como vemos acima (Gráfico 1), as linhas paralelas nos indicam a persistência das diferenças entre brancos e negros no Brasil. As Tabelas A12, A13 e A14 (Anexo A), nos dão uma oportunidade de distinguirmos as amplitudes extra e intragrupos, tendo a população negra como dado de referência nos anos de 2004 e 2011. A taxa de analfabetismo entre a população de 15 anos ou mais tinha uma diferença de 9,1\% entre brancos e negros em 2004; e caiu para 6,5\%; em relação ao Brasil a amplitude entre os negros e a população brasileira é de 4,8\%, em 2004, e de 3,2\% em 2011. Entre os negros a taxa de analfabetismo caiu cerca de $27,6 \%$ e entre os brancos foi de $26,4 \%$. 
Gráfico 2 - Comparação entre brancos e negros da taxa de frequência bruta na educação superior em 2004 e 2011

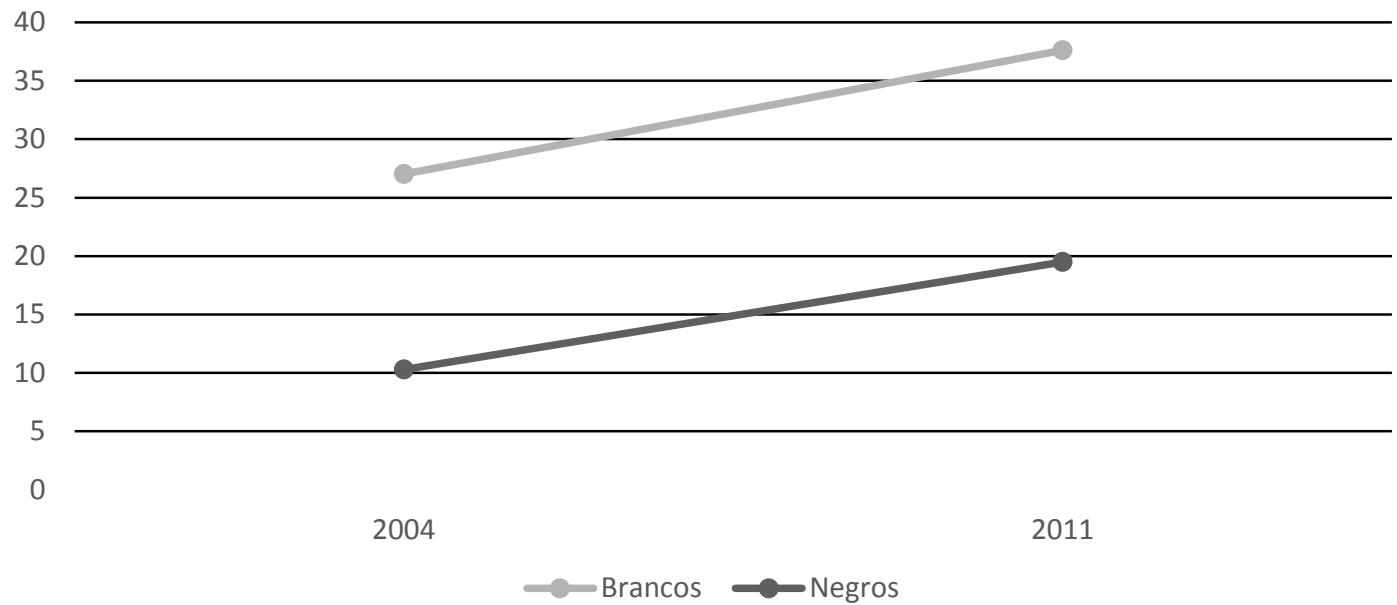

Fonte: Plano Mais Brasil PPA 2012-2015: agendas transversais - monitoramento participativo: ano base 2012/Ministério do Planejamento, Orçamento e Gestão - p. 29 - Elaboração própria, 2014

A frequência da população na educação superior também mostrou uma alta evolução entre os negros, com um aumento de $89 \%$ entre o período de 2004 e 2011, apesar de manter diferenças percentuais de $16,7 \%$ em 2004, e de 18,1\% em 2011, entre negros e brancos, o que significou uma elevação de $8,4 \%$ positivamente para a população branca (Gráfico 2). A taxa de frequência bruta na educação superior não nos permite aferir se a frequência na educação superior está em idade adequada, de 18 a 24 anos. Normalmente, para atender a esse critério o cálculo é realizado por agrupamento etário (Gráfico 2).

Dificilmente poderíamos afirmar que a alta evolução da população negra na educação superior se deve a uma política universalista de acesso ao ensino superior. Sabemos das políticas de ações afirmativas para elevar o acesso da população negra ao ensino superior com um grande destaque para as instituições de ensino superior públicas. Dados do GEMAA ${ }^{29}$ nos apontam que atualmente são cerca de 90 instituições que adotam algum tipo de medida para a inserção da população negra no ensino superior. Há um mérito também do Programa Universidade para Todos-Prouni, voltado às instituições de ensino superior privadas e que visa a proporcionar acesso a jovens de baixa renda com cota para negros e indígenas na sua seleção desde 2004. A Lei nº 12.711, de 2012, é a grande expectativa quanto ao futuro da

\footnotetext{
${ }^{29}$ GEMAA - Grupo de Estudos Multidisciplinar da Ação Afirmativa: http://gemaa.iesp.uerj.br/
} 
inserção da população negra no ensino superior sobretudo nas universidades estaduais e federais públicas. Essa lei reserva vagas para egressos das escolas públicas, com percentuais para negros e indígenas. Como houve uma exclusão da população negra que cursou o ensino médio em escolas privadas, mesmo que parcialmente, lançam-se dúvidas quanto à continuidade dos progressos alcançados até aqui pelas ações afirmativas.

Gráfico 3 - Comparação entre brancos e negros em relação ao rendimento médio de todos os trabalhos em 2004 e 2011 (R\$)

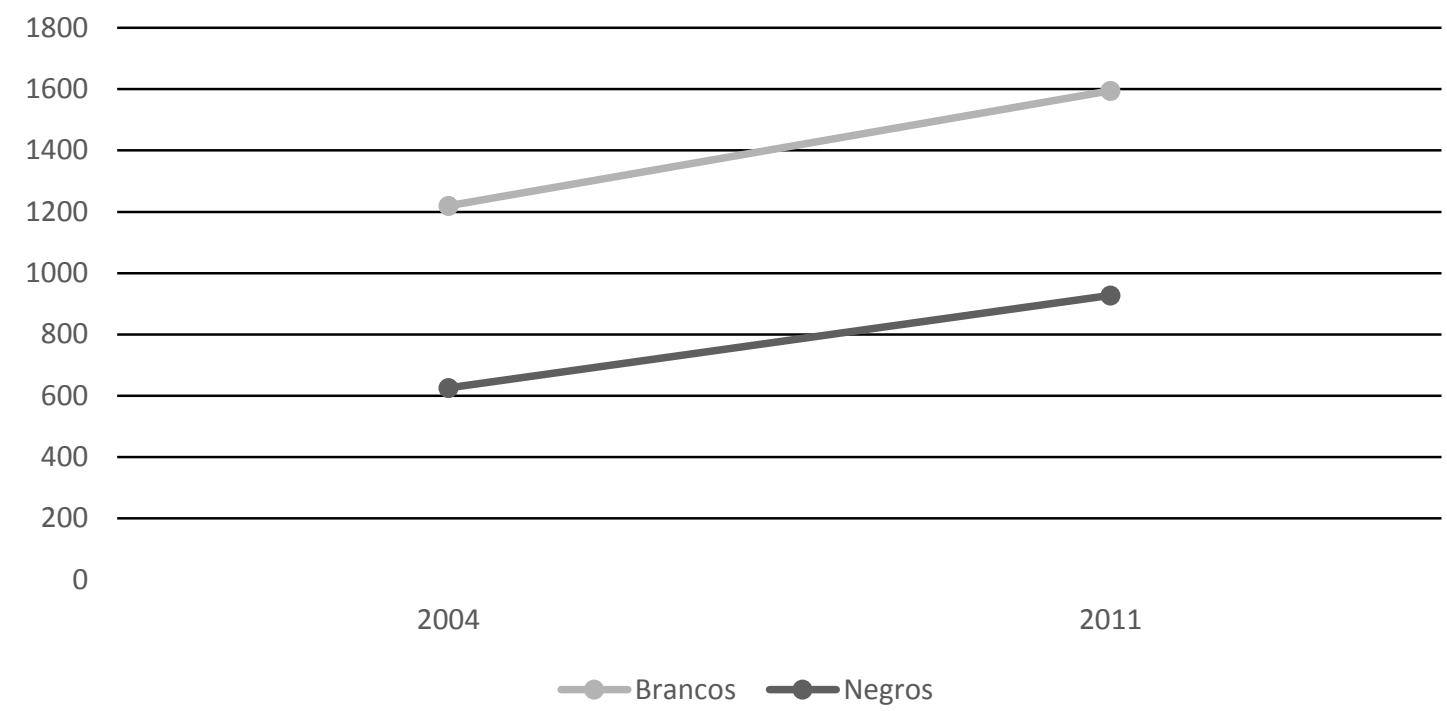

Fonte: Plano Mais Brasil PPA 2012-2015: agendas transversais - monitoramento participativo: ano base 2012/Ministério do Planejamento, Orçamento e Gestão - p. 29 - Elaboração própria, 2014

A diferença entre a população negra e a branca em relação ao rendimento mensal médio de todos os trabalhos nos apresenta que houve uma elevação dessa diferença de $12 \%$ quando olhamos para 2004 e 2011 (Gráfico 3). Apesar de observarmos que a população negra teve um aumento no seu rendimento de $48,1 \%$ e a população branca de 30,7\% (Gráfico 3). Isso significa que o ponto de partida já era elevado favoravelmente à população branca, pois a diferença se ampliou entre negros e brancos. 
Gráfico 4 - Comparação entre brancos e negros em relação ao percentual de pessoas que vivem em domicílios com escoadouro do banheiro ou sanitário por rede coletora ou fossa séptica em 2004 e 2011

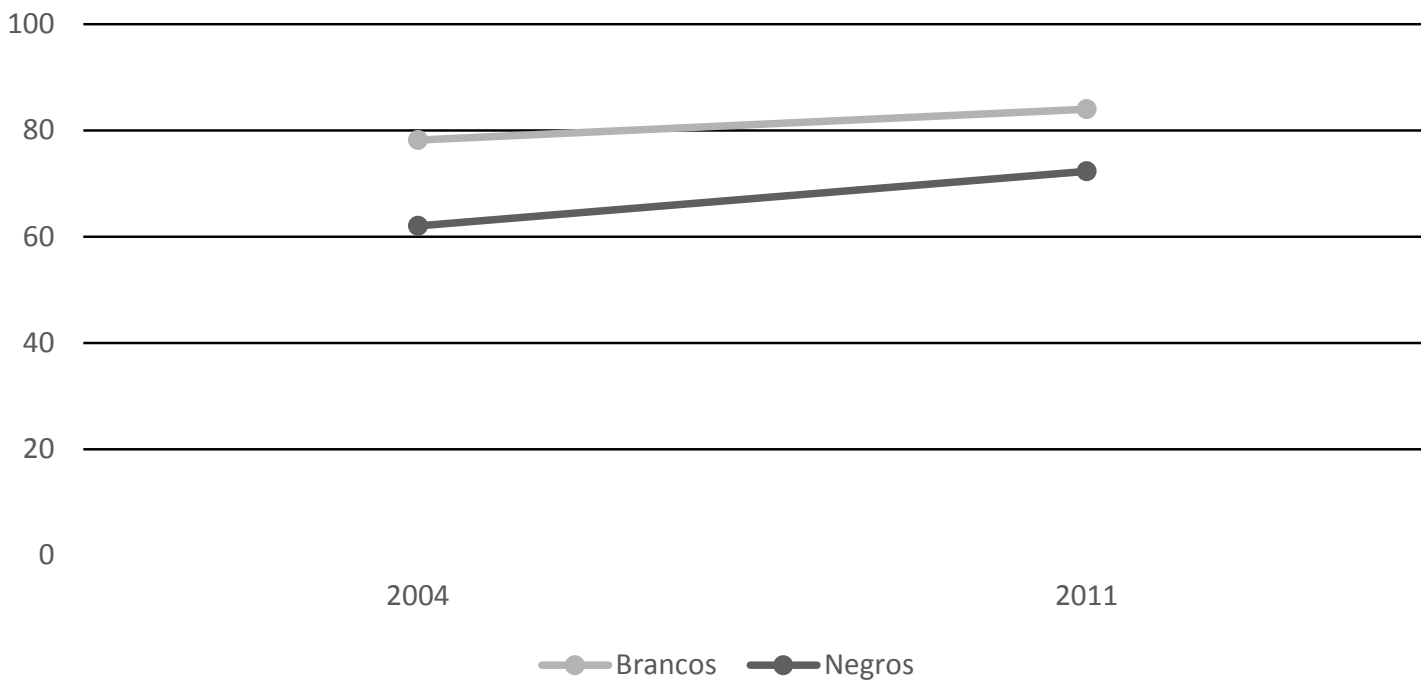

Fonte: Plano Mais Brasil PPA 2012-2015: agendas transversais - monitoramento participativo: ano base 2012/Ministério do Planejamento, Orçamento e Gestão - p. 29 - Elaboração própria, 2014

O Gráfico 4 nos apresenta o aumento do percentual de pessoas negras que vivem em domicílios com escoadouro do banheiro ou sanitário por rede coletora ou fossa séptica. Apesar do gap entre os grupos negros e brancos, houve um aumento maior entre os negros do que entre os brancos no período de 2004 e 2011. Esse indicador de saneamento básico teve um aumento $7,4 \%$ entre os brancos e de $16,6 \%$ entre os negros. 
Gráfico 5 - Comparação entre brancos e negros em relação ao percentual de pessoas que vivem em domicílios com máquina de lavar roupas em 2004 e 2011

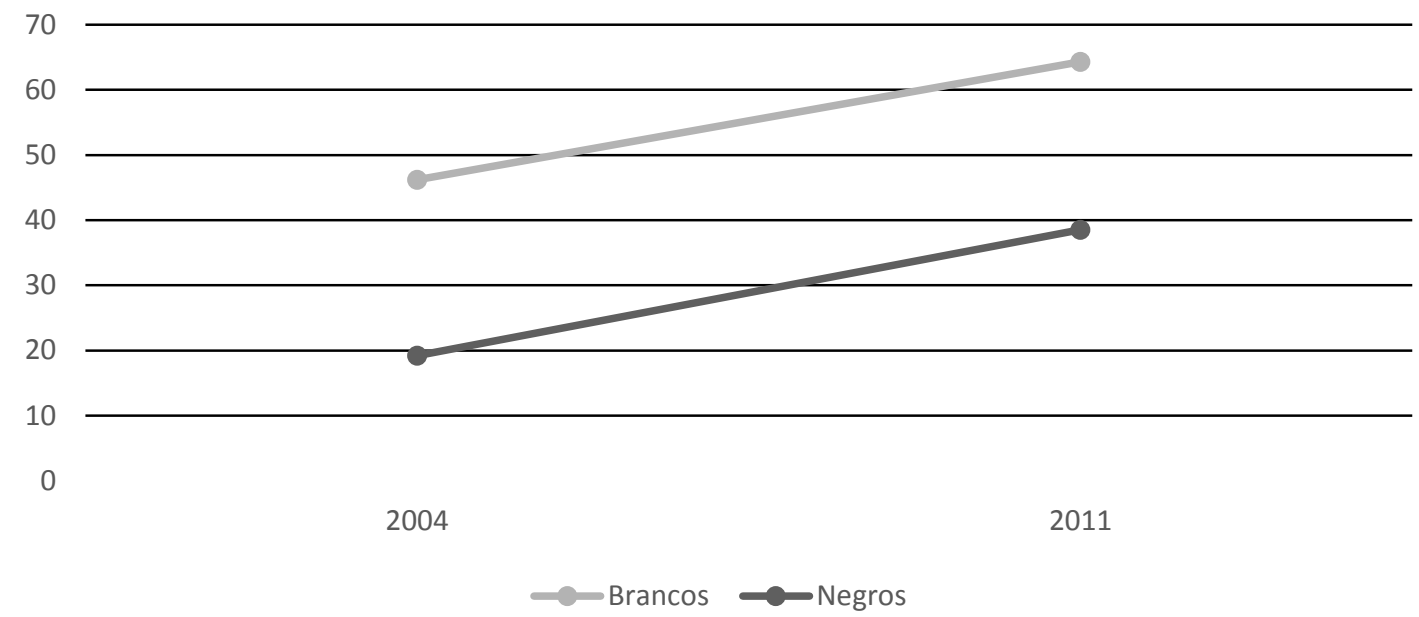

Fonte: Plano Mais Brasil PPA 2012-2015: agendas transversais - monitoramento participativo: ano base 2012/Ministério do Planejamento, Orçamento e Gestão - p. 29 - Elaboração própria, 2014

Quando se observam os dados de acesso a bens, comparando a situação em 2004 e em 2011, vemos que houve um aumento de mais de $100 \%$ da população negra que vive em domicílio com máquinas de lavar roupas (Gráfico 5; Tabela A14, Anexo A). Em 2004, 19,2\% dos negros viviam em domicílios com máquina de lavar roupas; em 2011, o percentual era de 38,5\% (Tabela A14, Anexo A). Essa amplitude entre a população branca foi de 39,2\% (Gráfico 5, Tabela A14, Anexo A). Sinais do que tem sido discutido sobre o boom econômico no Brasil das primeiras décadas do século XXI com a ampliação de crédito a juros baixos; o aumento real do salário mínimo; a queda na taxa de desemprego; e a dinamização de setores da economia como a construção civil e o setor de serviços. 
Gráfico 6 - Comparação entre brancos e negros em relação à taxa de homicídios de jovens do sexo masculino de 15 a 29 anos por 100 mil habitantes em 2004 e 2011

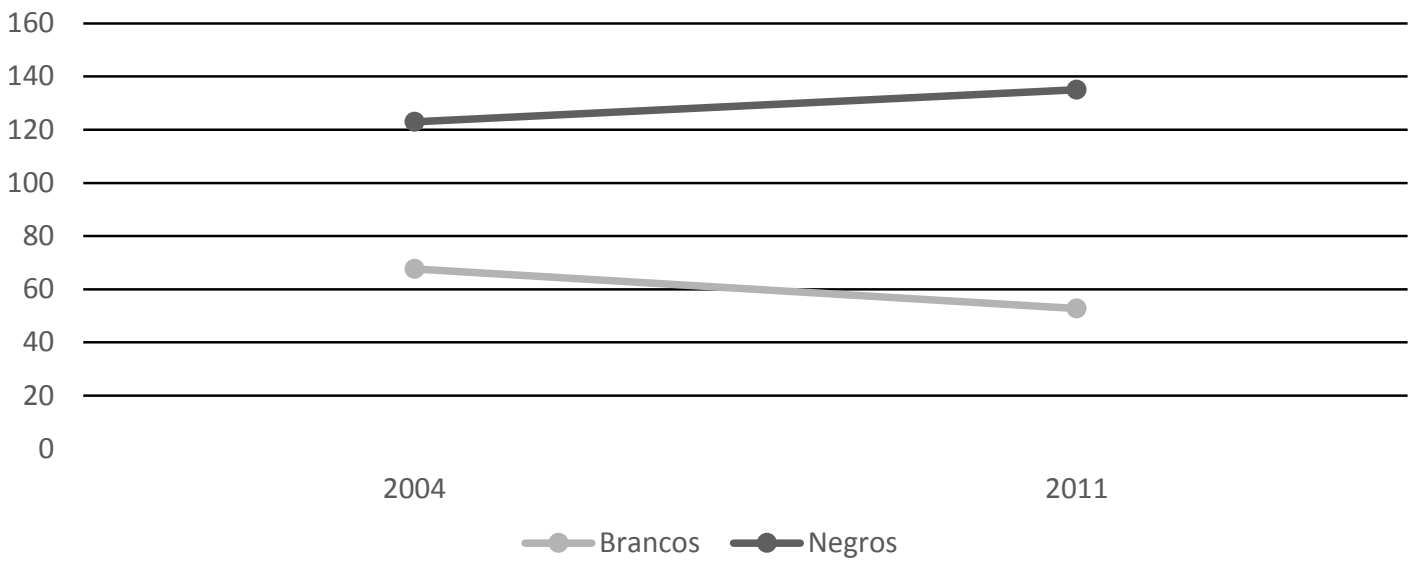

Fonte: Plano Mais Brasil PPA 2012-2015: agendas transversais - monitoramento participativo: ano base 2012/Ministério do Planejamento, Orçamento e Gestão - p. 29 - Elaboração própria, 2014

Por outro lado, vemos o acirramento de outras questões sociais já há muito denunciadas pelo movimento social negro brasileiro. No Gráfico 6 analisamos a taxa de homicídios entre jovens do sexo masculino de 15 a 29 anos por 100 mil habitantes que subiu de forma alarmante no período de 2004 a 2011. De 122,97 entre os jovens negros em 2004 para 135,07 em 2011. Entre os jovens brancos, a mesma taxa foi reduzida de 67,62 para 52,75. Comparativamente em 2004, a diferença entre a taxa de homicídio entre jovens brancos e negros era de 55,35; em 2011, a diferença aumentou para 82,32. Houve um aumento de $48,7 \%$ entre essas diferenças. Enquanto no grupo de jovens negros o aumento foi de 9,8\%, entre os brancos houve uma redução de $22 \%$ na taxa de homicídios ${ }^{30}$.

\footnotetext{
${ }^{30}$ A Organização das Nações Unidas considera aceitável o índice de 10 homicídios para cada grupo de 100 mil habitantes.
} 
Gráfico 7 - Comparação entre brancos e negros em relação ao percentual das populações de 18 a 24 anos que não estudam, não trabalham, nem estão procurando emprego em 2004 e 2011

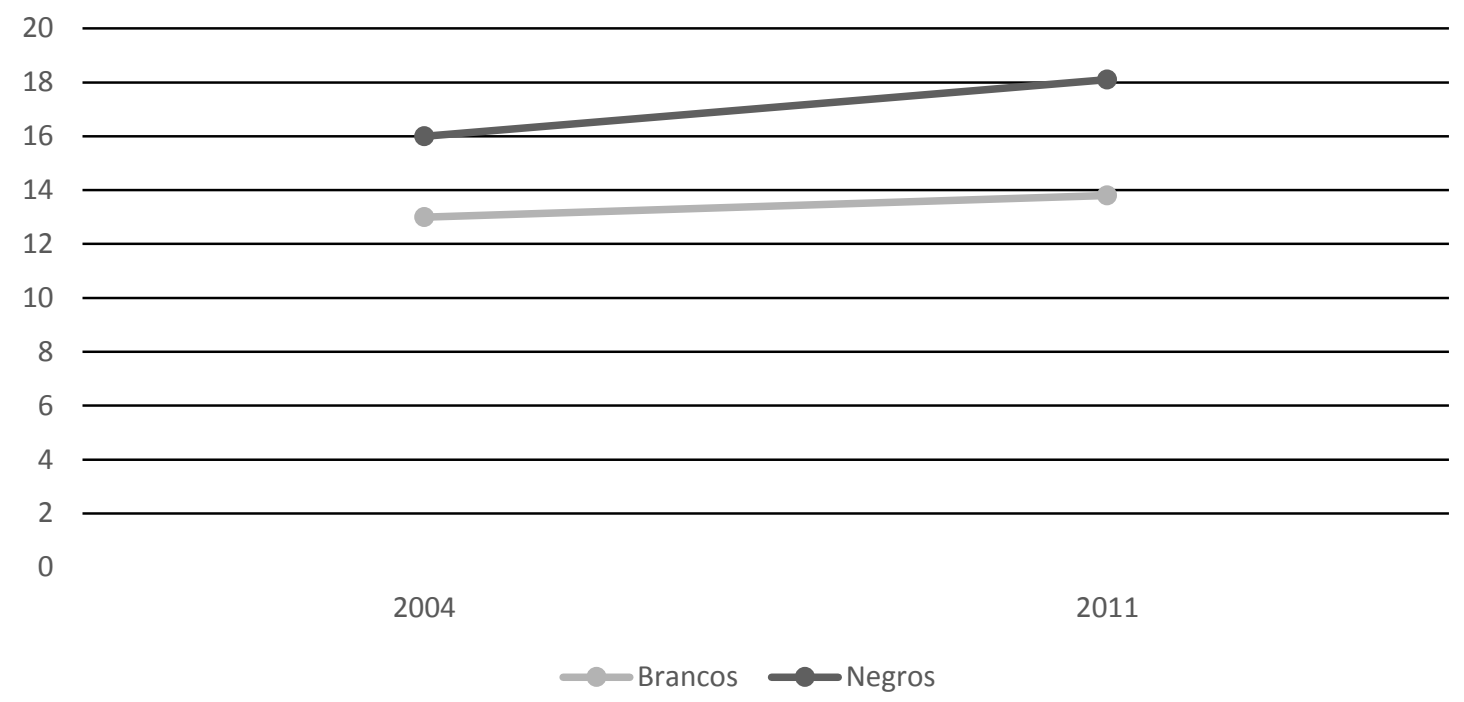

Fonte: Plano Mais Brasil PPA 2012-2015: agendas transversais - monitoramento participativo: ano base 2012/Ministério do Planejamento, Orçamento e Gestão - p. 29 - Elaboração própria, 2014

Uma outra inflexão sobre a população jovem. Quando se analisa a população de 18 a 24 anos que não estuda, não trabalha, nem está procurando emprego, encontramos um aumento de $13 \%$ entre os negros e 6,2\% entre os brancos (Gráfico 7). 
Gráfico 8 - Comparação entre brancos e negros em relação ao percentual das populações de 25 a 29 anos que não estudam, não trabalham, nem estão procurando emprego em 2004 e 2011

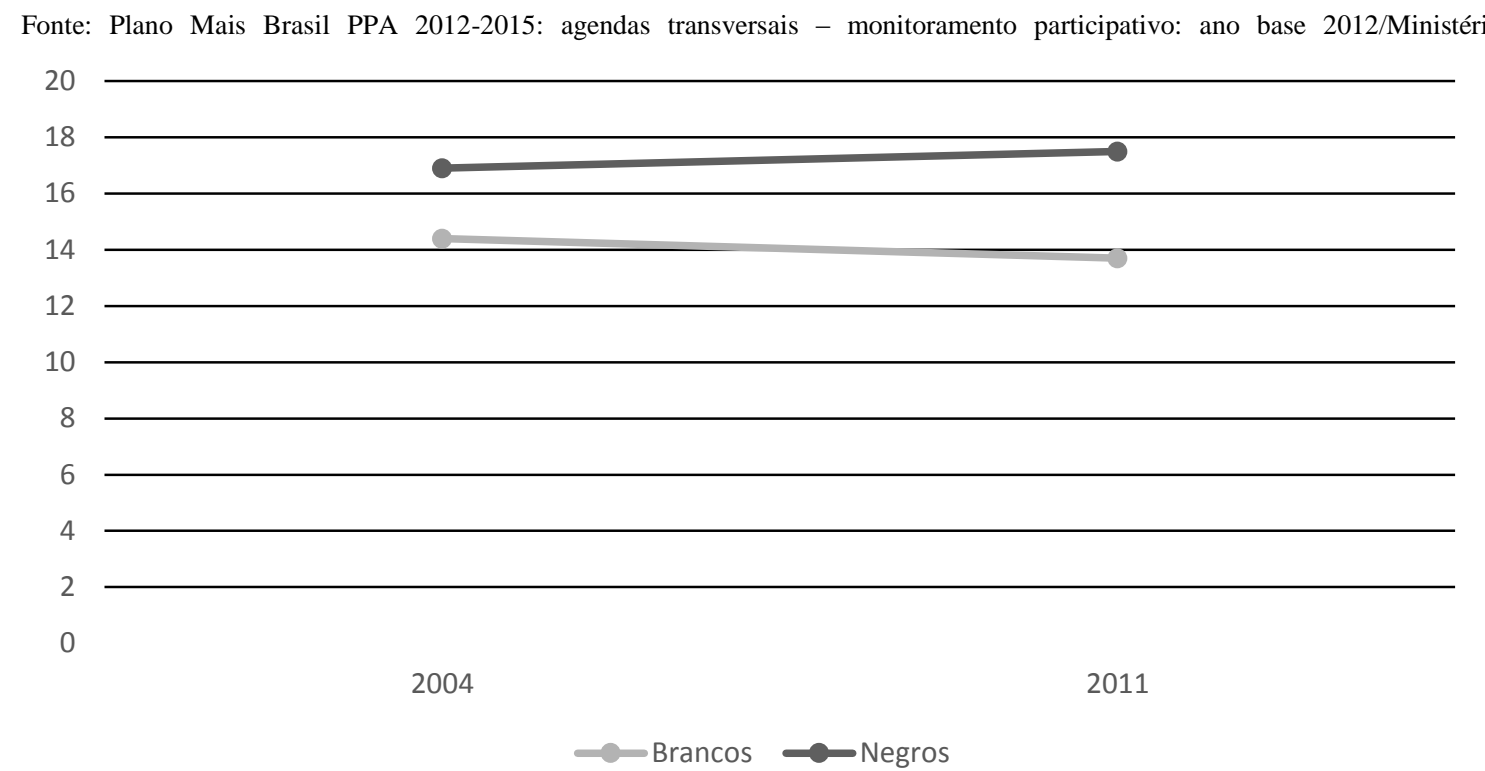

Planejamento, Orçamento e Gestão - p.29 - Elaboração própria, 2014

No Gráfico 8, observamos que entre a população jovem de 25 a 29 anos que não estuda, não trabalha e nem está procurando emprego houve um aumento de 3,6\% entre a população negra e de $4,9 \%$ entre a população branca.

Esses dados nos permitem inferir que, apesar da intervenção governamental ter trazido melhoras para a população brasileira, incluindo, obviamente, a população negra, se não houver políticas públicas de caráter mais focalizado para tratar especificamente da problemática que envolve esse grupo de pessoas, as diferenças continuarão persistindo, quando não muito se agravando, como vem ocorrendo nos homicídios contra jovens negros.

O desafio a ser colocado para os responsáveis pelos programas governamentais é a identificação minuciosa do perfil socioeconômico do público-alvo e de que forma este público está tendo acesso às políticas universais. A inclusão de indicadores e do quesito cor e/ou raça na coleta de dados de serviços prestados é importante para se avançar nesse monitoramento e avaliação (CAVENAGHI, 2007). Somente após colocar uma lupa na 
execução das políticas públicas, seria possível pensar nas políticas universais como uma única estratégia legítima para erradicar ou diminuir as desigualdades raciais ${ }^{31}$.

Ações transversais de promoção de igualdade racial deveriam ser verticais na estrutura dos órgãos públicos. Caracterizaria a transversalidade ter como público alvo a população negra em cada política, programa, ação, projeto ou atividade. A transversalidade seria consubstanciada em orientações estratégicas para toda ação tática e operacional das políticas públicas. Essa forma de estruturação das políticas públicas para a população negra pode levar a um compromisso político e institucional na execução dessas políticas, pois autoridades públicas com poder de decisão teriam a responsabilidade sobre a efetividade das políticas de promoção da igualdade racial. Diminuiriam as falências de políticas que têm orçamento, mas não têm autorização para gastá-lo. Evidentemente que, quando nos posicionamos dessa forma estamos normatizando um processo de gestão da política pública, pois a expectativa de nossos dirigentes entrevistados é baixa para ocorrer alguma alteração na estrutura de gestão dessas políticas.

Diante desse quadro, a SEPPIR não seria mais responsável por micropolíticas de promoção da igualdade racial, mas, sim, por articulação e monitoramento, dotada de um corpo técnico e político de alto nível e com legitimidade junto à administração pública e aos movimentos sociais. Diminuiria a sobreposição de agendas e microações sem escala e nem impacto na problemática racial. O mais importante é ter capacidade de articular, monitorar, estabelecer pontes e de dialogar com diferentes atores e ações que objetivem promover a igualdade racial no Brasil. Não se trata de ampliar os instrumentos de gestão da SEPPIR, mas de imputar esse desafio aos demais órgãos do governo federal.

Acima, discutiram-se os desafios da SEPPIR para se alcançar efetividade nas políticas de promoção da igualdade racial. Todos os órgãos de articulação de políticas de direitos humanos ( SDH, SPM, SEPPIR) denunciam as suas deficiências de gestão. Não será a SEPPIR a responsável pela execução de políticas de saúde, de educação, de habitação que tenha como público-alvo a população negra. Mas será a responsável pela formulação e

\footnotetext{
31 Para uma análise sobre a transversalidade das políticas públicas federais, sobretudo para grupos em desvantagem social consultar (IPEA, 2009).
} 
monitoramento juntamente com os órgãos setoriais. Dessa forma, irá compartilhar responsabilidade pelo sucesso da política no espaço governamental e na sociedade civil.

\subsection{Conclusões preliminares}

Conforme a linha teórica que optamos por discutir, as políticas de promoção da igualdade racial não têm uma natureza única, ora assumem um caráter redistributivo, ora de reconhecimento. A história do movimento social negro nos faz admitir que ele caminhou sozinho ao carregar a bandeira de denúncia do falso reconhecimento associado à ideia de democracia racial no Brasil, ideologia que se desmascara nas precárias condições de vida sociais e econômicas da população negra.

As propostas políticas extraem suas raízes no protagonismo de indivíduos que dedicaram a sua vida ao movimento social negro, não havendo partido de esquerda ou de direita que tenha levantado a bandeira de forma autônoma. A luta pela consciência histórica da população negra é um outro aspecto ressaltado pelo movimento social negro, e com a instituição de políticas afirmativas destoada de uma política de reconhecimento de identidade, desemboca fatalmente no que Gomes (2001) discute como o desaparecimento da consciência racial, porque, à medida que negros ocupem determinadas posições antes privilégio da população branca, tendem a reduzir "sentimentos de frustração, de injustiça e sobretudo a forte consciência racial dos negros tenderá também a desaparecer, na medida em que passarão a acreditar que podem obter sucesso na vida unicamente em razão de suas capacidades individuais" (GOMES, 2001:69). Gomes reflete essa discussão sobre os negros dos Estados Unidos, mas aqui, no Brasil, seria o sepultamento de uma consciência da massa negra que nunca existiu.

As políticas de promoção da igualdade racial não objetivam somente ações redistributivas ou de reconhecimento. A sua natureza é múltipla, visam à distribuição de recursos materiais, à busca da dignidade e à integridade física pelo reconhecimento do valor da cultura e da história do indivíduo. Isso poderia ser remediado pela efetiva instituição de ações afirmativas no escopo das políticas de promoção da igualdade racial em que caberia ao Estado monitorar o grau de participação da população negra nos diversos espaços sociais e econômicos e chamar a sociedade para promover a legitimidade democrática. 
Mas o caminho seriam as políticas focalizadas? Acreditamos que o primeiro ponto é entendermos que as políticas de promoção da igualdade racial não excluem a universalidade das políticas sociais. Elas possuem caráter emancipatório ao preconizar a efetividade das igualdades de oportunidade para a população negra. Elas surgem da luta e da organização dos movimentos sociais negros ao longo da história brasileira. As reivindicações e mobilizações do movimento social negro e dos atores políticos internacionais formaram a agenda governamental que tornou possível migrar a questão racial de uma não situação e de um estado de coisas para um problema político. As políticas universais têm como pressupostos a transformação social por meio das estruturas sociais e econômicas, sendo imprescindível a sua aplicação concomitantemente às políticas focalizadas voltadas à questão racial em face da natureza dos problemas raciais no Brasil, que requer um grau de intervenção para reverter um processo histórico de exclusão. A denúncia e os objetivos a serem atingidos pelas políticas de promoção da igualdade racial são as variáveis intervenientes de que a universalidade pode não dar conta.

A desigualdade racial tem sido uma luta encampada pelo movimento social negro não apenas como um resultado do período escravocrata ou das diferenças de classes sociais, mas são efeitos concretos de atitudes racistas baseadas no preconceito racial que perpassa a cultura brasileira.

A análise das circunstâncias da baixa capacidade técnica e institucional das políticas de promoção da igualdade racial nos leva a concluir que essas políticas são ações voltadas à diminuição e à erradicação da desigualdade racial. Todavia, elas carecem de apoio técnico e institucional para alcançar os seus objetivos. A escassez na estrutura de gestão, como a restrição orçamentário-financeira e o dimensionamento quantitativo e qualitativo da força de trabalho, reflete a baixa efetividade dessas políticas. Isso contradiz os discursos institucionais sobre a priorização das políticas de promoção da igualdade racial pelos tomadores de decisão.

Parte dessa análise se vale da literatura atual sobre as políticas de promoção da igualdade racial e sobre os seus operadores. Esses estudos discutidos aqui apontam alguns obstáculos 
para fazer avançar o combate à desigualdade racial na agenda governamental. Primeiro, a dificuldade em admitir que existe racismo no Brasil e que esse perpassa toda a estrutura da sociedade brasileira. Segundo, o mito da democracia racial. O Brasil não alcançou esse ideal igualitário. Contudo, a democracia racial ofusca qualquer tentativa de fazer avançar para a prática o discurso de promover a igualdade racial no Brasil, dando um caráter de neutralidade às políticas públicas (BERNARDINO-COSTA, 2002). Terceiro, há um ambiente social e político para que as pessoas se posicionem a favor das ações de combate à desigualdade racial, sem, entretanto, saírem do caráter protocolar.

Completada a análise da instituição das políticas de promoção da igualdade racial, vimos que as políticas públicas têm o espaço social como a sua arena de intervenção e que cabe ao Estado a promoção da execução dessas políticas. O Estado traz as percepções, os valores e a moral dos indivíduos que neles atuam. As instituições públicas agem sob a condução de seu corpo burocrático. Os atos institucionais podem, dessa forma, estar enviesados de preconceitos, de ideias discriminatórias ou racistas. Como podemos, assim, entender os ideais que perpassam a cultura das instituições públicas refletida em sua prática organizacional por meio da burocracia? É o que pretendemos discutir nos próximos capítulos. 


\title{
Capítulo 2 - Procedimentos Metodológicos
}

\author{
Sem esquecer que o ser humano é ativo e livre, com suas \\ próprias ideias, opiniões, preferências, valores, \\ ambições, visão das coisas, conhecimentos..., que é \\ capaz de agir e reagir.
}

Cristian LAVILLE e Jean DIONNE (1999: 33)

O objetivo deste capítulo é apresentar os procedimentos metodológicos que nortearam a coleta de dados e as análises consubstanciadas neste trabalho. A opção metodológica para o desenvolvimento deste trabalho consistiu em uma combinação de métodos, um levantamento (survey) e entrevistas. Survey é uma técnica de pesquisa muito propícia para a análise multivariada (SIMÕES; PEREIRA, 2007), valemo-nos dessa metodologia para estudarmos um conjunto grande de sujeitos e para entendermos percepção e valores.

Dessa forma, esta pesquisa se fundamenta em dados quantitativos obtidos por meio da aplicação de um questionário on-line e em dados qualitativos coletados via entrevistas baseadas em um questionário estruturado. Os sujeitos da pesquisa são servidores membros das chamadas Carreiras Típicas de Estado: Advogado da União, Analista de Planejamento e Orçamento, Especialista em Políticas Públicas e Gestão Governamental, Procurador Federal e Técnico de Planejamento e Pesquisa do Instituto de Pesquisa Econômica Aplicada-Ipea. Essas carreiras foram eleitas para o estudo em razão da sua atuação no ciclo de formulação, implementação e avaliação de políticas públicas no governo federal.

Uma parte do questionário on-line contém questões sobre o perfil socioeconômico e a outra parte, frases para aferir a opinião dos respondentes quanto a sua concordância ou discordância em relação a propostas de políticas de promoção da igualdade racial; e em relação ao papel do Estado (Anexo B). Adotamos a escala de Likert com cinco pontos, sendo 1. Concorda muito; 2. Concorda; 3. Não concorda, nem discorda; 4. Discorda e 5. Discorda muito. 
As questões expressam enunciados de políticas públicas voltadas especificamente para a população negra e, numa outra versão do questionário, as frases expressam políticas públicas especificamente para a população pobre. Comparamos se existem diferentes grau de apoio entre a problemática racial e a problemática social, considerando os termos negro ou pobre e suas variações (Anexo B). Quaisquer flutuações nas respostas são atribuídas aos efeitos das variáveis que estão sendo testadas, negro e pobre. O questionário foi validado pelo teste piloto. A confiabilidade do instrumento foi aferida por meio da partição da amostra durante o teste piloto. Trabalhamos com o SurveyMonkey ${ }^{32}$, uma ferramenta de pesquisa on-line, que nos possibilitou construir o questionário, cadastrá-lo e enviá-lo para os respondentes deste estudo.

Gostaríamos de ressaltar algumas implicações sobre o desenho da pesquisa que poderiam enviesar os resultados, mas que não se concretizaram. A primeira foi o nível de informação e escolaridade dos pesquisados. Isso não foi um obstáculo, pois tínhamos uma população homogênea (Quadro 1); o nível superior é a escolaridade mínima exigida para exercer os cargos nas carreiras. Além da escolaridade homogênea, apostamos que esses servidores públicos já deveriam ter alguma noção, pelo menos “ouvido falar”, das ações de cunho racial e de combate à pobreza.

Quadro 1 - Características heterogêneas e homogêneas das carreiras pesquisadas

\begin{tabular}{|c|c|}
\hline \multicolumn{2}{|c|}{ INTRAGRUPOS } \\
\hline Características heterogêneas & Características homogêneas \\
\hline $\begin{array}{l}\text { Sexo } \\
\text { Faixa Etária } \\
\text { Curso Superior (exceto Carreira Jurídica, onde } \\
\text { todos tinham graduação em direito) }\end{array}$ & $\begin{array}{l}\text { Cargo } \\
\text { Remuneração inicial e final } \\
\text { Nível de instrução } \\
\text { Conhecimentos básicos e específicos exigidos para } \\
\text { o concurso }\end{array}$ \\
\hline \multicolumn{2}{|c|}{ EXTRAGRUPOS } \\
\hline Características heterogêneas & Características homogêneas \\
\hline $\begin{array}{l}\text { Lotação } \\
\text { Curso Superior (exceto Carreira Jurídica, onde } \\
\text { todos tinham graduação em direito) } \\
\text { Cargo } \\
\text { Conhecimentos básicos e específicos exigidos para } \\
\text { o concurso }\end{array}$ & $\begin{array}{l}\text { Nível de instrução } \\
\text { Faixa etária } \\
\text { Remuneração inicial e final }\end{array}$ \\
\hline
\end{tabular}

Fonte: Elaborado pela autora, 2014

${ }^{32}$ http://pt.surveymonkey.com 
O segundo desafio foi elaborar perguntas que não levassem a respostas socialmente aceitáveis. Atualmente, no cenário nacional há medidas que poderiam ter influenciado o contexto social do participante e refletido no levantamento de dados. Citamos a provação da Lei $n^{\circ} 12.288 / 2010$ ( Estatuto da Igualdade Racial) e a votação no Supremo Tribunal Federal-STF sobre a constitucionalidade do sistema de cotas da Universidade de Brasília. Essas ações poderiam ter influenciado a opinião dos participantes sobre concordar com as propostas de políticas de promoção da igualdade racial, daí realizamos um esforço para não induzir o respondente a acreditar que haveria algum nível de desejabilidade social.

\subsection{Respondentes e entrevistados}

Tínhamos um total de 7.585 servidores membros das carreiras. Tivemos 950 questionários respondidos e após a exploração dos dados, restaram 854 questionários que foram utilizados para a análise final. Eliminamos 96 casos ausentes nas variáveis carreira e cor e/ou raça. Alguns respondentes deixaram em branco o item sobre cor e/ou raça e como cada questão respondida levava a outra questão a ser respondida, após o item sobre cor e/ou raça não respondido não tínhamos mais dados preenchidos. Interpretamos essa situação como dados perdidos completamente ao acaso, não houve uma tendência para a perda dos dados observados, pois a ausência dos dados não foi em função da variável dependente. Consideramos a possibilidade de substituição dos dados perdidos pela média ou pelo resultado mais frequente, mas como os missings foram cerca de $10 \%$ descartamos esse tratamento dos dados para não induzir a viés de análise conforme orientam Hair et al ( 2007:61). Também, não eliminamos variáveis, mas eliminamos os casos onde os dados ausentes se encontravam.

Os resultados desta pesquisa não podem ser generalizados para todas as carreiras participantes deste estudo e nem para todas as carreiras consideradas típicas de Estado, pois não trabalhamos com uma amostra aleatória das carreiras. A amostra dos respondentes do questionário foi por conveniência, ou seja, a participação foi voluntária o que pode nos dar uma indicação útil de tendências (GRAY, 2011). Enviamos um link para acessar o questionário a todos os servidores das carreiras, solicitando sua participação na pesquisa e 
informando a não identificação daqueles que respondessem o questionário. Os resultados, portanto, circunscrevem somente entre aqueles servidores que participaram da pesquisa.

Fisicamente, entrevistamos 21 servidores das carreiras mencionadas, havendo no mínimo dois entrevistados em cada carreira. O processo de seleção dos entrevistados foi aleatório por meio de números aleatórios ou randômicos atribuídos a todos os membros das carreiras. Utilizamos a função ALEATÓRIOENTRE do programa Excel para a seleção dos 21 entrevistados. Esses participantes são denominados neste artigo de "entrevistados". Para chegar a esses entrevistados elaboramos uma lista dos sorteados e aqueles que se recusavam eram repostos na lista. Assim, seguíamos com a lista dos nomes sorteados até alguém aceitar participar da entrevista. Consideramos que houve uma boa recepção e retorno dos nossos contatos, sorteamos 28 potenciais entrevistados, houve recusa de sete pessoas. Também, entrevistamos ex-dirigentes de políticas de promoção da igualdade racial que atuaram durante o governo Fernando Henrique Cardoso, FHC (1995-2002) e no governo de Luís Inácio Lula da Silva, Lula (2003-2011). Entrevistamos cinco ex-dirigentes destes períodos para este trabalho, cunhamos esses entrevistados como "dirigentes".

Utilizamos o termo servidor ou servidores como sinônimo de servidor estável, concursado, investido em cargo público de provimento efetivo ou de carreira. Cargo efetivo previsto na estrutura organizacional do Estado que não o cargo comissionado. O termo servidor público ou servidores públicos é utilizado para designar as pessoas que não são concursadas e que ocupam cargos públicos por meio de cargo em comissão (DASs) ou função de confiança. Os cargos em comissão ou função de confiança são investidos de função de direção, chefia e assessoramento e as pessoas investidas nos cargos em comissão podem não possuir vínculo efetivo com o Estado, ou seja, não precisariam ser servidores efetivos para o exercício de cargo gerencial.

\subsection{Nível socioeconômico}

Um dos nossos propósitos era entender a origem social dos nossos participantes como um dos pressupostos da teoria da burocracia representativa. Para analisarmos a origem social dos participantes da pesquisa, precisávamos saber a escolaridade, a ocupação principal e a cor e/ou raça do pai e da mãe de nossos participantes. Primeiramente, iremos explicar como 
construímos o nível socioeconômico que nos auxiliou na análise da origem social dos participantes. Não discutiremos mobilidade social, apesar de ser intuitivo que para aqueles cujo pai ou mãe não estavam nos estratos mais altos, houve sem dúvida uma mobilidade social porque hoje pertencem a uma classe de servidores públicos.

O nível socioeconômico é um elemento para entendermos de onde os nossos respondentes vem e como as variáveis de origem social se comportam. O propósito é apontar as origens sociais dos nossos respondentes e lançarmos a ideia de que isso pode ter sido um fator determinante para que eles chegassem onde chegaram profissionalmente. A discussão do mérito caberia aqui. Condições que lhes trouxeram oportunidades para a disputa igual e/ou privilegiada no mercado de trabalho público.

\subsubsection{Construção do nível socioeconômico}

O nível socioeconômico é um constructo teórico latente, não podendo ser mensurado diretamente. Alves e Soares (2009) nos informam que as escalas de índices socioeconômicos são construídas a partir da média de variáveis sociodemográficas dos indivíduos. Essas variáveis são ocupação, nível de instrução, renda e, algumas vezes, idade ou sexo. Esses mesmos autores argumentam que os procedimentos metodológicos diferem de pesquisador para pesquisador, mas os resultados são muito semelhantes. Educação tem um peso maior do que a renda e as demais variáveis têm peso bem menor. Para o propósito deste estudo, vamos destacar alguns trabalhos de referência na construção de escalas de classificação socioeconômica.

A posição das ocupações em pesquisas de estratificação social são mensuradas de três maneiras: prestígio social; categorias de classe e de escores de status socioeconômico (GANZEBOOM; DE GRAAF; TREIMAN, 1992). Há escalas que são referência internacionalmente e que dão conta desses três métodos de construção: Standard International Occupational Prestige Scale (SIOPS) construída por Treiman, (1977 apud GANZEBOOM; DE GRAAF; TREIMAN, 1992) que foi codificada na International Standard Classification of Occupations (ISCO ou CIOU - Classificação Internacional Uniforme de Ocupações) revisada em 1968 e 1988 (ISCO88/CIOU88). A escala 
ISCO/CIOU também contou com a participação de Treiman atendendo a uma demanda da Organização Internacional do Trabalho-OIT. Outra escala, Erickson and Goldthorpe's class categories (EGP) criada pelos seus homônimos (ERIKSON; GOLDTHORPE, 1987a, b, 1988; ERIKSON; GOLDTHORPE; PORTOCARERO, 1979, 1982, 1983) e o International Socio-Economic Index (ISEI) desenvolvido por Ganzeboom, De Graaf e Treiman (1992). O ISEI foi atualizado e correlacionado com a SIOPS e EGP utilizando a ISCO88 para uniformização das categorias ocupacionais (GANZEBOOM; TREIMAN, 1996).

O Brasil utilizou como base a ISCO88 para construir a Classificação Brasileira de Ocupações-CBO pelo Ministério do Trabalho e Emprego em 2002. A CBO2002 é um documento que normaliza o reconhecimento, a nomeação e a codificação dos títulos e ocupações do mercado de trabalho brasileiro.

Alves e Soares (2009) desenvolveram uma metodologia para medir o nível socioeconômico por meio da Teoria da Resposta ao Item-TRI, uma técnica de agregação de indicadores de uma variável latente. Os dados empíricos para a construção do nível socioeconômico por esses autores foram extraídos da pesquisa GERES - Pesquisa Longitudinal da Geração Escolar 2005, polo Belo Horizonte. Os autores trabalharam com dados sobre educação, ocupação e renda das famílias. A renda foi aferida por meio da renda do setor censitário, dada a limitação de levantar o valor da renda dos pais tendo como fonte de informação os alunos participantes daquela pesquisa. Alves e Soares (2009) trabalharam ainda com a escala de status socioeconômico proposta por Pastore e Silva (2000).

Optamos por trabalhar com o ISEI - International Socio-Economic Index. Um índice desenvolvido por Ganzeboom, De Graaf e Treiman, (1992) com base em censos nacionais, inclusive o censo do Brasil, onde utilizaram dados sobre educação, ocupação e renda dos indivíduos. Os autores pretendiam que o ISEI fosse aplicado a qualquer tipo de pesquisa sem a necessidade de levantar dados primários sobre educação e renda. Isso veio a calhar para o nosso estudo, pois não levantamos dados sobre a renda dos pais dos nossos respondentes. No nosso entendimento teríamos uma dificuldade em obter respostas fidedignas dos nossos participantes porque a renda dos pais e da família só teria feito sentido na infância, adolescência e início da fase adulta desde que ainda estivessem sob a dependência do pai 
e/ou da mãe. Então, a nossa fonte de informação seria membros da família que na época não eram os responsáveis principais. A capacidade de fazer distinção da renda da família há tanto tempo atrás não seria tão forte e a chance de nós obtermos respostas válidas seria muito baixa. Alves e Soares (2009) e Jannuzzi $(1999,2003)$ problematizam essas limitações para trabalhar com a renda post-fact, pois o dado viria do participante, mas a renda informada não seria a sua, mas de seu pai, mãe ou responsável.

Outros estudiosos na linha de pesquisa sobre estratificação social e mobilidade desenvolveram escalas de classificação socioeconômica para a realidade brasileira. Utilizaram sobretudo os dados do Censo Demográfico e da Pesquisa Nacional por Amostra de Domicílio (PNAD) ambos produzidos pelo Instituto Brasileiro de Geografia Estatística (IBGE). Um estudo clássico na área é de Silva (1973) que construiu com os dados do Censo de 1970 uma escala de diferenciação social das ocupações comparando com escalas internacionais de Blishen (1958 apud Silva, 1973) e Bogue (1963 apud Silva, 1973). Pastore (1979) utilizou essa escala proposta por Silva (1973) em seu estudo sobre a mobilidade social no Brasil, tendo a PNAD de 1973 como referência. Com os dados da PNAD de 1996, Pastore e Silva (2000) atualizaram o estudo de 1979 desenhando um índice de status socioeconômico com a finalidade de analisar como se comportou a mobilidade social no país entre 1973 e 1996. A escala foi derivada do nível educacional e rendimentos dos indivíduos a partir das suas ocupações registradas na PNAD. Os estratos ocupacionais são hierarquizados em (1) Baixo-inferior; (2) Baixo-superior; (3) Médio-inferior; (4) Médiomédio; (5) Médio-superior; e (6) Alto. Santos (2005) propõe uma nova classificação socioeconômica para o Brasil numa perspectiva teórico marxista de análise de classe fundamentado nos trabalhos de Wright (1978, 1997, 2002, 2004, 2005 apud Santos 2005 ). O esquema de classificação socioeconômica elaborado pelo autor tem o intuito de analisar o impacto da desigualdade de classe sobre a desigualdade de raça. $\mathrm{O}$ autor define a classificação desenhada como uma "solução criativa" haja vista a complexidade da estrutura social brasileira. Critica a adoção pela PNAD-2002 de uma classificação ocupacional inspirada na International Standard Classification of Occupations (ISCO88/CIOU88), pois trabalha com 519 grupos ocupacionais desagregados, mas não delimita o grande agrupamento de "ocupações elementares" conforme a inspiração internacional, o que levou a exclusões de grupos, empobrecendo a PNAD em relação às anteriores. As categorias 
construídas por Santos (2005) são: Capitalistas e fazendeiros; Pequenos empregadores; Conta própria não agrícola; Conta própria agrícola; Especialistas autoempregados; Gerentes; Empregados especialistas; Empregados qualificados; Supervisores; Trabalhadores; Trabalhadores elementares; Conta própria precários; Empregados domésticos.

Pedagogicamente, os procedimentos metodológicos para a construção de uma escala socioeconômica são explorados por Jannuzzi (1999). O autor ilustra por meio de estatísticas multivariadas a construção de uma escala socioocupacional tendo como fonte de dados a Pesquisa Regional por Amostra Domiciliar-PRAD de 1993. Jannuzzi (1999) procura esclarecer, ainda, que a tradição na escolha da ocupação do indivíduo como indicador de classe social se assenta em diferentes critérios teóricos, sejam eles de orientação weberiana ou marxista. Outros indicadores para operacionalizar a posição do indivíduo na estrutura social, como educação e renda, sustenta o autor, carecem de confiabilidade metodológica, como "problemas de lembrança e erros de declaração e racionalizações post-fact (status autoconferido)" (JANNUZZI, 1999:09). O autor trabalhou, para cada grupo ocupacional, com o perfil médio de escolaridade e a mediana do rendimento do trabalho. As categorias construídas foram quatro, (1) Baixo; (2) Médio-baixo; (3) Médio-alto; (4) Alto. Propondose a desenhar uma metodologia para a segmentação do mercado consumidor brasileiro, Jannuzzi (2003) atualiza o esquema de classificação socioocupacional para pesquisa social em cinco estratos, utilizando os Censos Demográficos de 1980 e 1991 e as PNADs dos anos 90. O autor questiona a "cegueira" de analistas de mercado quanto a outros critérios de segmentação socioeconômica do mercado consumidor no Brasil. Argumenta que ainda se baseiam em critérios geográficos e poder de consumo. Segundo o autor, o poder e os hábitos de consumo tendem a perder cada vez mais validade devido a facilidade de aquisição de produtos eletrodomésticos e eletrônicos impulsionados pela oferta de crédito, formas de pagamento, queda nas taxas de juro e também de preços. Um outro aspecto apontado por Jannuzzi (2003) é que as escalas baseadas na posse de bens duráveis de médio prazo estão baseadas numa família tradicional, um casal com duas ou mais crianças e isso, atualmente, não tem sustentação pois há cada vez mais casais optando em não terem filhos, quando muito, tem apenas uma criança; pessoas vivendo sozinhas; e o envelhecimento da população que inverte a relação de consumo para serviços em vez de produtos. Como uma opção de critério metodológico, o autor chega a propor um retorno à renda familiar como em tempos 
de baixa inflação, sem deixar de mencionar as limitações já discutidas em 1999. Contudo, esses problemas conhecidos levam o autor a propor uma escala socioeconômica de ocupações constituída de: (1) Baixo; (2) Médio-baixo; (3) Médio; (4) Médio-alto; (5) Alto.

Como vimos há um lastro de estudos sobre a produção de esquema de classificação socioeconômica no Brasil e internacionalmente. Não nos sentimos impelidos a desenvolver uma escala própria para hierarquizar socialmente os nossos respondentes. A opção que fizemos pelo ISEI nos pareceu mais acertada ao enfatizar uma medida contínua para os nossos propósitos de análise empírica, assim como por dispensar a informação sobre renda. O ISEI possui 271 grupos ocupacionais, os escores variam de 16 a 90 . O menor escore é relativo a categorias profissionais de trabalho manual e doméstico e o maior escore é a ocupação de juiz. Utilizamos a escala do ISEI atualizada apresentada no trabalho de 1996 de Ganzeboom e Treiman. Inicialmente, uniformizamos as ocupações do pai e da mãe declaradas pelos respondentes, por exemplo, todos os Engenheiros Civis ou Engenheiros Elétricos foram classificados como Engenheiros. A ocupação definida como dona de casa foi classificada como dado ausente. A partir daí, tratamos essa informação, codificando-a para a Classificação Brasileira de Ocupações-CBO e em seguida convertemos o código da ocupação na CBO para a base da ISCO $88^{33}$. Assim, o código da ocupação na ISCO88 foi cotejado na tabela ISEI onde identificamos o índice de classificação da ocupação.

Uma outra decisão importante foi a escolha entre o índice do pai ou da mãe. Optamos pelo índice de maior status, ou seja, o maior ISEI considerando a posição social feminina quando era maior do que a masculina. Alves e Soares (2009) nos esclarece que tradicionalmente as pesquisas sociais utilizam a ocupação do homem adulto para definir o nível socioeconômico. Apesar do protagonismo feminino pela sua própria condição social e de sua família, a escolha da ocupação masculina ainda hoje se sustenta segundo os autores. Esse entendimento passou a ser questionado a partir da década de 1970 com a atuação dos movimentos feministas. Aguiar, Fernandes e Neves (2007), ao avaliar a mobilidade social das mulheres, considera que a união do status econômico do marido com o da esposa determina em grande parte a posição social de seus filhos. Considerando a hipótese levantada

\footnotetext{
${ }^{33}$ O Ministério do Trabalho e Emprego disponibiliza em seu site uma tabela eletrônica para conversão entre bases: http://www.mtecbo.gov.br/cbosite/pages/tabua/ConsultasConversao.jsf
} 
por esses últimos autores, acreditamos que eleger o maior status ocupacional entre o pai ou a mãe, como fizemos, significa decidir pelo poder econômico maior dentro da família.

Entretanto, a nossa opção metodológica pela escolha do maior ISEI não se confirmou empiricamente, as Tabelas A8 e Tabela A9 (Anexo A) demonstram que em números absolutos as cinco principais ocupações exercidas pelos pais são engenheiro, servidor público superior, comerciante, advogado e médico enquanto as mães exerciam funções como dona de casa, professora, servidora pública superior, médica e comerciante. Como já esclarecemos, a categoria dona de casa não foi ponderada no índice socioeconômico. Essas ocupações, levam a condição masculina a ter uma prevalência na construção do maior status ocupacional. O grau de escolaridade do pai e da mãe também nos empurrou para a predominância masculina no índice aferido. Ainda que próximos, há uma frequência maior entre os pais com níveis de instrução maiores do que entre as mães em todas as carreiras consideradas conforme descrito nas Tabelas A10 e A11 (Anexo A). 


\title{
Capítulo 3 - Quem são os nossos participantes
}

\begin{abstract}
Quando a necessidade de administração pelos especialistas é considerável, e os seguidores dos partidos têm de reconhecer uma "opinião pública" intelectualmente desenvolvida, educada e livre, o uso de funcionários sem habilitações prejudicará o partido que ocupe o poder, nas próximas eleições.
\end{abstract}

Max WEBER (1971:235)

No nosso entendimento, no Poder Executivo da Administração Direta e Indireta, as chamadas carreiras típicas de Estado formam a alta burocracia técnica do serviço público. Optamos por trabalhar neste estudo com algumas carreiras que integram as chamadas "Carreiras Típicas de Estado": Analista de Planejamento e Orçamento, Especialista em Políticas Públicas e Gestão Governamental, Técnico de Planejamento e Pesquisa, Advogado da União e Procurador Federal. Neste capítulo realizaremos uma breve descrição dessas carreiras como uma tentativa de demonstrar a sua atuação. Todavia, esbarramos na dificuldade de expressar concretamente a atividade dos membros dessas carreiras dada a dinâmica e o enquadramento dos processos de trabalho no cotidiano da administração pública. Além, dos servidores dessas carreiras, apresentaremos também uma descrição de dirigentes públicos entrevistados que atuaram em políticas de promoção da igualdade racial.

As chamadas Carreiras Típicas de Estado desenvolvem atividades exclusivas de Estado previstas na Constituição Federal (art. 247). As atividades exclusivas de Estado são atividades relacionadas à fiscalização tributária, à fiscalização trabalhista, à fiscalização agropecuária, às finanças, ao orçamento, ao planejamento e ao controle dos processos burocráticos da Administração Pública, à gestão pública, à segurança pública, à defensoria e advocacia pública, à diplomacia, à regulação de setores econômicos, à política monetária, à magistratura, à defesa da ordem jurídica e dos interesses da sociedade. Parte dessas carreiras foi reestruturada pela Lei $n^{\circ} 11.890 / 2008$. São carreiras que pertencem ao Poder Executivo da Administração Pública Direta e Indireta e que são de estrito interesse para este estudo. Seguem abaixo as suas descrições. 


\subsection{Analista de Planejamento e Orçamento-APO}

A carreira de Analista de Planejamento e Orçamento foi criada juntamente com a Secretaria de Planejamento e Coordenação da Presidência da República ${ }^{34}$. Esta carreira tem funções de planejamento, orçamento e finanças na gestão pública. Atualmente, o lócus preferencial de atuação dos Analistas de Planejamento e Orçamento é o Ministério do Planejamento, Orçamento e Gestão ${ }^{35}$. Entretanto, esses servidores também exercem funções técnicas e gerenciais em outras unidades administrativas do Poder Executivo, geralmente em unidades responsáveis pela execução orçamentária e financeira de algum órgão governamental. Um projeto de lei de iniciativa do Presidente da República, por exemplo, precisa de um parecer sobre o impacto orçamentário e financeiro. Assim, para seguir com a sua tramitação, a proposta de projeto de lei deve mencionar se a despesa decorrente da medida está prevista na lei orçamentária anual; se não, quais são as alternativas para custeála; e se haveria necessidade de abertura de crédito extraordinário, especial ou suplementar ${ }^{36}$. Logo, são as unidades onde normalmente atuam os Analistas de Planejamento e Orçamento que emitem esse parecer de previsão orçamentária e financeira.

\subsection{Especialista em Políticas Públicas e Gestão Governamental-EPPGG}

A carreira de Especialista em Políticas Públicas e Gestão Governamental-EPPGG, mais conhecida como Gestor Governamental, foi criada dentro de um contexto de formação de uma alta burocracia que pudesse levar a cabo propostas de reforma administrativa na Nova República. Em 1985, o Governo Sarney promoveu uma reforma administrativa para reestruturar o Estado com fins de racionalização e diminuição dos gastos estatais. O pano de fundo era o processo de redemocratização do Brasil que trazia novas demandas da sociedade.

O que reforça mais ainda a tese que as concepções da carreira de EPPGG nasce dentro da vigência da redemocratização do Estado brasileiro (GUEDES, 2013; SOUZA, 2002; SANTOS; CARDOSO, 2000). A proposta de criação da carreira já aparecia em 1982 no

34 Decreto-lei no 2.347 , de 23 de julho de 1987

35 Art. 30 da Lei ${ }^{\circ} 9.625 / 98$

36 Manual de Redação da Presidência da República 
Relatório Rouanet que influenciou também a criação da Escola Nacional de Administração Pública (ENAP). A ENAP nasceu com a missão de formar os altos administradores da gestão pública (ROUANET, 2005). Uma ideia gestada dentro do Departamento Administrativo do Serviço Público-DASP. O Departamento foi criado no governo de Getúlio Vargas em 1938 e teve um importante papel durante o regime militar como um órgão de planejamento e coordenação administrativa do poder executivo.

Até a sua afirmação institucional, a carreira de EPPGG passou por instabilidades. Criada em $1989^{37}$, a carreira foi extinta em 1991 na reforma administrativa do Governo Color e incorporada à carreira de Analista de Orçamento (GUEDES, 2013; PETRUCCI; BRITO; CASTRO SANTOS, 1995). Após esse advento, a carreira de EPPGG somente foi restaurada em 1992, entretanto, a sua consolidação acontece com Bresser Pereira, então Ministro do Ministério da Administração e Reforma do Estado do Governo de Fernando Henrique Cardoso em 1995.

A carreira de Gestor Governamental teve como inspiração o cargo de Administrateur Civils formado pela École Nationale d'Administration (ENA), escola de governo francesa ${ }^{38}$. À despeito de estarem longe do que se propunha o seu desenho inicial como afirmam e constatam Cheibub e Mesquita (2001), cabe aos EPPGGs a execução de atividades de formulação, implementação e avaliação de políticas públicas, assim como de direção e assessoramento em escalões superiores da Administração Direta e Autárquica. O órgão supervisor desta carreira é a Secretaria de Gestão Pública (SEGEP) do Ministério de Planejamento, Orçamento e Gestão. Os EPPGGs podem exercer funções técnicas e gerenciais em quaisquer unidades administrativas da Administração Pública, incluindo Poder Legislativo e Poder Judiciário $^{39}$. Assim, ao tempo em que estão exercendo uma função técnica em alguma Diretoria, podem exercer a gerência desta Diretoria, podem assessorar a Diretoria e podem até mesmo exercerem outras funções executivas de mais alto escalão. Portanto, com esse amplo leque de atuação e circulação, um EPPGG poderia ser o técnico que formula o projeto de lei, que gerencia a unidade propositora ou que assessora a alta administração.

37 A carreira de EPPGG foi criada pela Lei ${ }^{\circ}$ 7.834, de 6 de outubro de 1989. Essa lei foi revogada pela Lei $\mathrm{n}^{\circ} 8.216$, de 1991 e revigorada pela Lei $\mathrm{n}^{\circ} 8.460$, de 1992.

38 A ENA serviu como modelo para a criação no Brasil da ENAP- Escola Nacional de Administração Pública.

39 Lei $^{\circ}$ 9.625/98 concomitante à Lei ${ }^{\circ} \quad 11.890 / 2008$ 


\subsection{Técnico de Planejamento e Pesquisa do Ipea}

Os Técnicos de Pesquisa e Planejamento (TPPs) do Instituto de Pesquisa Econômica Aplicada (Ipea) atuam preferencialmente nesse órgão. Esses técnicos realizam pesquisas, estudos sociais e econômicos; apoiam técnica e institucionalmente o governo na avaliação, formulação e acompanhamento de políticas públicas, planos e programas; e oferecem à sociedade elementos para o conhecimento e a solução dos problemas e dos desafios do desenvolvimento brasileiro ${ }^{40}$. Maciçamente, no processo de formulação os técnicos do Ipea alimentam os tomadores de decisão com análises, dados e investigação sobre o mérito de uma proposta e também na fase de implementação com avaliação sobre os resultados parciais da execução das ações do Poder Executivo.

A carreira de Técnico de Planejamento e Pesquisa do Ipea se confunde com o próprio Instituto, pois passou a existir formalmente com a Constituição Federal de 1988. Antes, os seus funcionários eram contratados por meio da Consolidação das Leis Trabalhistas-CLT. A ideia do Ipea nasceu da vontade de existir um think tank fora da rotina da administração pública, pois já existia outros grupos de planejamento. Havia uma necessidade de constituir um grupo que ajudasse o governo a formular o planejamento de médio e longo prazo, segundo o primeiro presidente do Ipea, Roberto Campos (D'ARAÚJO; FARIAS; HIPPOLITO, 2005:21).

\subsection{Carreiras Jurídicas - Advogado da União e Procurador Federal}

Normativamente, as carreiras jurídicas têm como finalidade exercer atividades de consultoria e assessoramento jurídicos ao Poder Executivo ${ }^{41}$. Os Advogados da União atuam em órgãos da Administração Pública Direta ou nos núcleos de assessoramento jurídico da Advocacia-Geral da União-AGU. No processo de formulação de um projeto de lei, por exemplo, o Advogado da União, como advogado do órgão em que exerce suas funções, é responsável pela análise e parecer jurídico quanto ao aspecto legal de proposições. Há uma discussão se esses servidores devem ou não entrar no mérito das proposições, trataremos

\footnotetext{
${ }^{40}$ Decreto $\mathrm{n}^{\mathrm{o}} 7.142$, de 29 de março de 2010

41 Lei Complementar $n^{\circ} 73$, de 10 de fevereiro de 1993
} 
disso mais adiante. À despeito dessa controvérsia, a análise do Advogado da União embasa juridicamente a Administração Pública sobre os seus atos. O Poder Executivo para propor atos normativos deve responder a algumas questões legais, como se a União tem competência constitucional e legal para tomar tal providência; se a lei deve ter prazo de vigência limitado; se direitos estabelecidos serão ou não $\operatorname{afetados}^{42}$, aspectos que são trabalhados pelas carreiras jurídicas. A carreira de Procurador Federal é semelhante à carreira de Advogado da União, ou seja, exercem atividades de consultoria e assessoramento jurídicos. A diferença reside no seu lócus de atuação reservada à representação judicial e extrajudicial das autarquias e fundações públicas federais ${ }^{43}$.

O órgão supervisor das carreiras jurídicas é a Advocacia-Geral da União-AGU, criada pela Constituição Federal de 1988. A função que hoje é da AGU antes, cabia ao Ministério Público Federal-MPF: atuar na defesa da União, além de defender a ordem jurídica, o regime democrático, os interesses sociais e os interesses individuais indisponíveis. Antes de 1988, a Advocacia Consultiva da União era quem atuava em conjunto com o MPF. Isso era embaraçoso, pois “ele, o MPF, poderia demandar contra o Estado, na defesa de conquistas institucionais num instante, e em outro poderia estar contestando pretensões idênticas em defesa da União" (CARVALHO, 2009:98).

A AGU veio especializar a defesa da União, livrando o Ministério Público Federal dessa obrigação (CARVALHO, 2009). As Consultorias Jurídicas estão na estrutura administrativa dos Ministérios de Estado; as Procuradorias Federais estão na estrutura administrativa das Autarquias e Fundações dos Ministérios de Estado; e a Procuradoria da Fazenda Nacional está na estrutura administrativa do Ministério da Fazenda. As carreiras jurídicas têm dupla vinculação, num instante, elas estão subordinadas administrativamente onde estão lotadas, ou seja, nos Ministérios, nas Autarquias e nas Fundações; mas possuem uma subordinação técnica em relação a Advocacia-Geral da União. Essa subordinação se expressa na interpretação jurídica com o objetivo de pacificar e uniformizar temas que já foram tratados como uma forma de não “eternizar o debate” (GUIMARÃES, 2012:40).

\footnotetext{
${ }^{42}$ Manual de Redação da Presidência da República.

${ }^{43}$ Essa carreira foi criada pela Lei ${ }^{\circ} 10.480$, de 2 de julho de 2002.
} 
Apresentamos abaixo um fluxo como exercício do processo de atuação das carreiras selecionadas. O exemplo é uma representação da formulação de um projeto de lei até o seu envio ao Congresso Nacional, Figura 2, e uma exemplificação geral do processo de implementação de um programa de governo por meio de convênios, Figura 3. Para esse exercício, substituímos os possíveis órgãos governamentais pelos servidores que pertencem às carreiras estudadas como uma ilustração das funções desses burocratas. Nessa ilustração, os servidores são considerados segundo uma atuação ideal prevista pelas normas que regem as suas carreiras e em um trabalho conjunto entre eles. Não levamos em conta, também, a competência regimental, a investidura em cargos com autoridade técnica, gerencial e política para realizar as ações esboçadas. Ressaltamos também que o exemplo não pretende alcançar a complexidade da realidade que cerca essas carreiras no exercício de suas atividades. 
Figura 2 - Fluxo da atuação no processo de formulação de políticas públicas

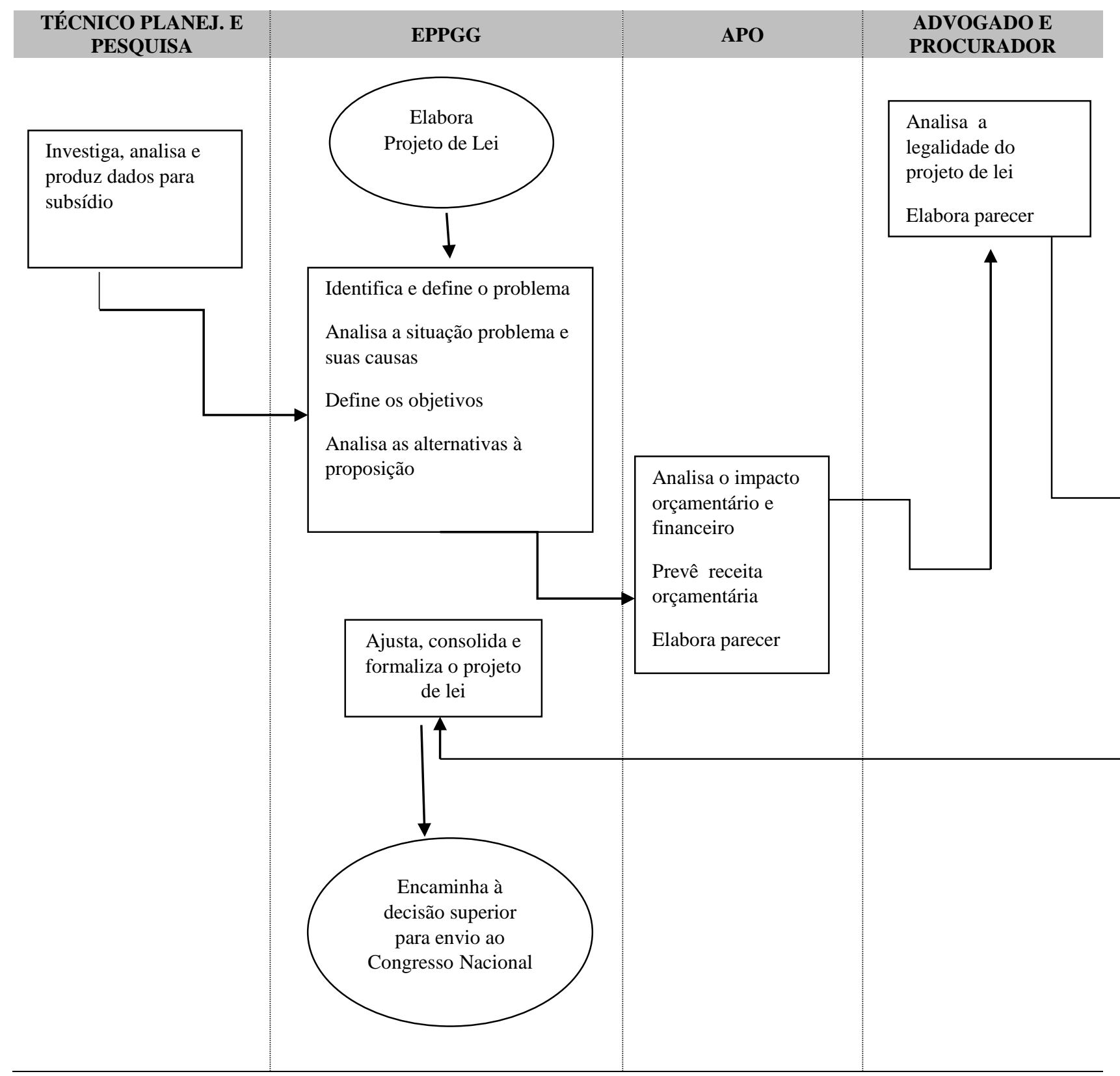


Figura 3 - Fluxo da atuação no processo de implementação de políticas públicas

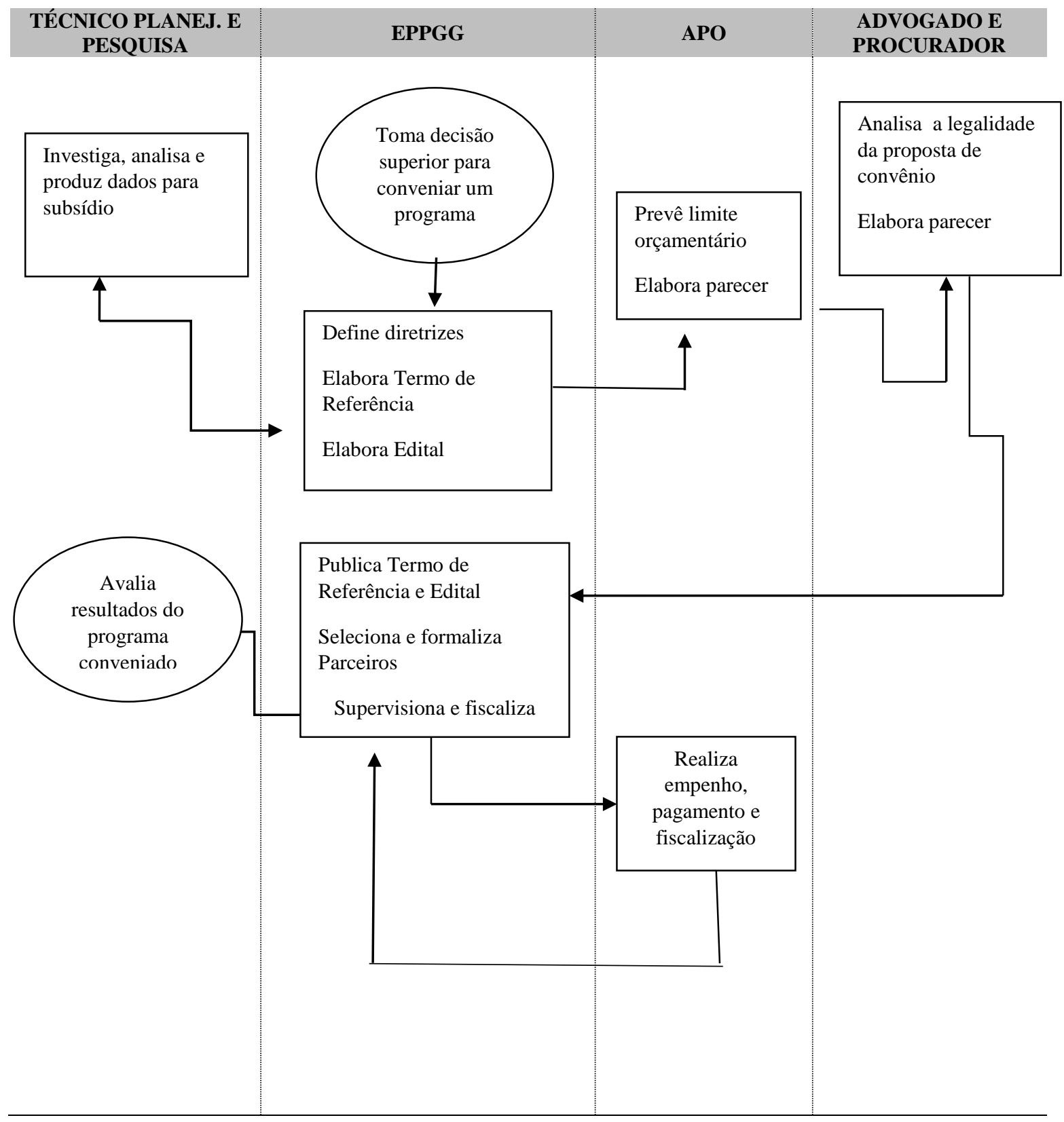


Antes de analisarmos as características desses servidores, apresentamos o perfil geral dessas carreiras com base nos dados do Boletim Estatístico de Pessoal, documento do Ministério do Planejamento, Orçamento e Gestão (Tabela 10).

Tabela 10 - Perfil dos servidores públicos ativos pertencentes às Carreiras Típicas de Estado selecionadas

\begin{tabular}{|c|c|c|c|c|c|c|c|c|}
\hline \multirow{2}{*}{ Carreira } & \multirow[t]{2}{*}{ Total } & \multicolumn{2}{|c|}{ Sexo } & \multicolumn{5}{|c|}{$\begin{array}{c}\text { Faixa etária } \\
(\%)\end{array}$} \\
\hline & & $\mathrm{F}$ & M & $\begin{array}{c}\text { Até } 30 \\
\text { anos }\end{array}$ & $\begin{array}{c}31 \mathrm{a} \\
40\end{array}$ & $\begin{array}{c}41 \mathrm{a} \\
50\end{array}$ & $\begin{array}{c}51 \mathrm{a} \\
60\end{array}$ & $\begin{array}{l}\text { Mais } \\
\text { de } 60\end{array}$ \\
\hline $\begin{array}{l}\text { Anal. de Planej. e } \\
\text { Orçamento }\end{array}$ & 588 & $\begin{array}{c}157 \\
(26,7 \%)\end{array}$ & 431 & 10,4 & 36,1 & 31,3 & 19 & 3,2 \\
\hline Esp.Pol.Pub.e & 1.043 & 362 & 681 & & & & & \\
\hline $\begin{array}{c}\text { Gestão } \\
\text { Governamental }\end{array}$ & & $(34,7 \%)$ & & 16,9 & 45,1 & 26,4 & 11,2 & 1,2 \\
\hline $\begin{array}{c}\text { Téc.Planej. e } \\
\text { Pesquisa - Ipea }\end{array}$ & 246 & $\begin{array}{c}51 \\
(20,7 \%)\end{array}$ & 195 & 8,1 & 33,3 & 30,9 & 19,9 & 7,7 \\
\hline $\begin{array}{l}\text { Advogado da } \\
\text { União }\end{array}$ & 1.662 & $\begin{array}{c}733 \\
(44,1 \%)\end{array}$ & 929 & 8,8 & 46,9 & 24,5 & 14,6 & 5,2 \\
\hline Procurador Federal & 4.046 & $\begin{array}{c}1.671 \\
(41,3 \%)\end{array}$ & 2.375 & 11,2 & 46,6 & 21,6 & 16 & 4,6 \\
\hline
\end{tabular}

* Advogado da União - lotado na Advocacia Geral da União

Fonte: Boletim Estatístico de Pessoal/MP - vol. 17, nº 200, Dez/2012

Observamos que a carreira Advogado da União possui, proporcionalmente, o maior quantitativo feminino, 44\%, muito diferente da carreira de Técnico de Planejamento e Pesquisa do Ipea que tem pouco mais de $20 \%$. Os dados geracionais nos trazem em qual faixa etária estão concentrados os servidores públicos desse grupo. Todas as carreiras têm uma alta concentração de servidores entre os 31 a 40 anos de idade. Entre os Advogados da União, cerca de $47 \%$ estão nessa faixa etária. A carreira do Ipea é a que possui um maior quantitativo de servidores entre os 51 anos e mais de 60 anos, cerca de $28 \%$. Por outro lado, a carreira de Especialista em Políticas Públicas e Gestão Governamental é a que possui uma quantidade maior de jovens servidores: cerca de $17 \%$ têm até 30 anos. 
O perfil dos nossos entrevistados não foi muito diferente dos dados do Boletim Estatístico de Pessoal. Cabe lembrar que o documento do Ministério do Planejamento, Orçamento e Gestão traz o universo dos servidores, enquanto aqui trabalhamos com aqueles que se dispuseram em participar deste estudo.

Conforme a Tabela 11 abaixo, observamos que 11\% dos servidores das Carreiras Típicas de Estado selecionadas participaram deste estudo. Não podemos considerar este número uma amostra representativa, pois não trabalhamos com a aleatoriedade na seleção dos participantes como explicamos no capítulo anterior. Vemos que entre o grupo de participantes, proporcionalmente tivemos uma grande adesão dos Procuradores Federais, cerca de 38\%, seguido pelos Especialistas em Políticas Públicas e Gestão Governamental, 29\%. Os Técnicos de Pesquisa e Planejamento do Ipea tiveram a menor participação neste estudo. Entretanto, se olharmos para o total geral de servidores em cada carreira, observamos que os TPPs-Ipea tiveram a segunda maior participação, 15\%, após os EPPGGs, 24\%; e os Procuradores Federais, a carreira com a menor participação, 8\%. Isso se dá porque os TPPs-Ipea totalizam 246 servidores enquanto os Procuradores Federais, 4.046 conforme Boletim Estatístico de Pessoal/MP (vol.17, no 200, Dez/2012).

Tabela 11 - Total de participantes das carreiras selecionadas

Carreiras

Advogado da União

Analista de Planejamento e Orçamento

Especialista em Políticas Públicas e

Gestão Governamental

Procurador Federal

Técnico de Pesquisa e Planejamento do Ipea

Total

Fonte: Dados primários - Elaboração da própria autora
Frequência

\begin{tabular}{ccc}
171 & 20,0 & 10 \\
75 & 8,8 & 13 \\
247 & 28,9 & 24 \\
323 & 37,8 & 8 \\
38 & 4,4 & 15 \\
$\mathbf{8 5 4}$ & $\mathbf{1 0 0 , 0}$ & $\mathbf{1 1}$ \\
\hline
\end{tabular}




\subsection{Origem social dos participantes}

\subsubsection{Cor e/ou raça}

Não tínhamos informações sobre a cor e/ou raça dos servidores que participaram deste estudo. Apesar do $\mathrm{SIAPE}^{44}$ possuir campos para registros de cor/raça, eles são incompletos. Osório (2006) evidencia os esforços do governo federal em 2002 e 2003 para realizar um recenseamento racial que ficou aquém do esperado quando $40 \%$ dos servidores ativos responderam ao questionário. Mas, essa participação não é uma amostra representativa do serviço público, pois aqueles que responderam deixaram muitas imperfeições nos seus registros. Este mesmo estudo de Osório (2006) optou em considerar os servidores públicos em sua totalidade, não os diferenciando por carreiras ou por órgãos de lotação.

Ainda que o estudo de Osório (2006) não seja representativo do universo do serviço público, ele nos auxilia para algumas conclusões. Osório (2006) afirma que nas carreiras com maior remuneração os negros estão subrepresentados, isto não é diferente das carreiras que participaram deste estudo. Podemos concluir também que a maioria dos participantes são brancos (Tabela 12), vemos que as variações são semelhantes entre as carreiras, ou seja cerca de $70 \%$ são brancos em relação as demais cor e/ou raça.

Tabela 12 - Percentual de participantes das carreiras selecionadas segundo cor/raça

\begin{tabular}{|c|c|c|c|c|c|c|}
\hline & \multicolumn{5}{|c|}{ Cor/Raça } & \multirow{2}{*}{ Total } \\
\hline & Branca & Preta & Amarela & Parda & Indígena & \\
\hline Advogado da União & 75,4 & 4,1 & 1,2 & 19,3 & 0,0 & 100,0 \\
\hline $\begin{array}{l}\text { Analista de Planejamento e } \\
\text { Orçamento }\end{array}$ & 70,7 & 1,3 & 2,7 & 25,3 & 0,0 & 100,0 \\
\hline $\begin{array}{l}\text { Especialista em Políticas Públicas } \\
\text { e Gestão Governamental }\end{array}$ & 74,9 & 2,4 & 2,0 & 19,8 & 0,8 & 100,0 \\
\hline Procurador Federal & 69,0 & 4,0 & 0,3 & 26,3 & 0,3 & 100,0 \\
\hline $\begin{array}{l}\text { Técnico de Pesquisa e } \\
\text { Planejamento do Ipea }\end{array}$ & 71,1 & 5,3 & 0,0 & 23,7 & 0,0 & 100,0 \\
\hline Total & 72,2 & 3,4 & 1,2 & 22,8 & 0,4 & 100,0 \\
\hline
\end{tabular}

44 O Sistema Integrado de Administração de Pessoal (SIAPE) é de responsabilidade da Secretaria de Recursos Humanos do Ministério do Planejamento, Orçamento e Gestão e mantido pelo Serviço Federal de Processamento de Dados (SERPRO). 


\subsubsection{1. "Não concordo com a classificação de cor/raça do IBGE"}

Iremos fazer uma pausa na descrição dos nossos participantes, para discutirmos um dado que merece ser relatado, a dificuldade em obter o registro cor e/ou raça em pesquisa. Vamos tomar como dado aqueles que participaram do questionário on-line e das entrevistas presenciais. Ainda que a maioria dos participantes tenha se declarado branco, acreditamos que alguns deixaram de responder ao questionário em razão do registro cor e/ou raça. Temos cerca de $10 \%$ de missing, ou seja, não respondentes. Alguns possíveis respondentes, enviounos e-mails criticando a presença dessa pergunta no questionário e também o fato de não ter havido uma opção de resposta "não declarado".

Essa é uma questão que poderíamos deixar de lado, pois não é o foco ou objetivo deste trabalho, mas é um bom tema para contextualizarmos o debate sobre a burocracia e as políticas sociais e de promoção da igualdade racial.

A pergunta sobre a cor e/ou raça do entrevistado deveria ser simples. Afinal, utilizamos as categorias já trabalhadas há muito tempo pelo $\mathrm{IBGE}^{45}$ : branca, preta, amarela, parda e indígena. Mas, não foi simples. Alguns entrevistados se mostraram constrangidos com essa pergunta. A maioria das pessoas que entrevistamos pessoalmente poderiam ser classificadas como brancas hajam vistas as categorias sociológicas do cotidiano do brasileiro. Isso nos remeteu ao texto de Norvell (2001) sobre o desconforto das camadas médias brasileiras quando indagadas sobre a sua "brancura". O autor acredita que esse constrangimento se deve ao fato de a classe média relutar em aceitar a designação de "europeia e portuguesa" (NORVELL, 2001:260). Adianta também que isso é totalmente coerente com o discurso de sermos um país miscigenado "não se fala da brancura como característica valorizada (...) quando é inevitável, devido ao tom da pele ou à descendência de imigrantes recentes, costumam aceitar o rótulo com incômodo ou constrangimento" (NORVELL, 2001:260).

Acreditamos que o constrangimento e a não valorização da "brancura" seja um aspecto que pode ser encontrado em nossos respondentes. O que conseguimos apreender na fala das

\footnotetext{
${ }^{45}$ O quesito cor passou a ser introduzido no Censo Demográfico de 1872 (ARAUJO, 1987).
} 
pessoas para se negar ou problematizar a categorização de cor/raça é o discurso da miscigenação brasileira. Um bom exemplo é o Entrevistado 8 que optou por registrar "Não declarado", disse:

\begin{abstract}
Eu sempre tive problemas nessa classificação, minha mãe é bem morena, meu pai que é um pouco mais branco, minha avó é bem morena. Então na minha família sempre houve essa mistura. Então o que é se identificar como branco? É meio complicado, como nós somos um país que tem uma mescla muito grande, isso no XXX (Estado de nascimento do entrevistado, esclarecimento nosso) a gente tem uma população...um Estado onde há uma população negra muito grande eu era o branquinho. Mas a rigor eu não me acho branco, sou orgulhoso de ter uma família...diríamos multicultural. Então, assim, acho difícil esse tipo de categorização, entendeu, do IBGE. Eu tenho dificuldades com essa categorização, tanto é que no Censo eu coloquei não declarado porque eu não consigo dizer que eu sou branco se a minha mãe é bem morena e eu sou orgulhoso dessa mistura que tem na minha casa, acho um negócio um pouco complexo. (Entrevistado 8)
\end{abstract}

Um Procurador Federal, se declarou como branco, um pouco resignado, pois se disse contrário a essa forma de classificação "porque eu acho que o brasileiro é altamente miscigenado. E na minha família eu tenho origem branca, negra e...indígena, eu não sei. Mas, pela cor predominante, eu me classificaria como branco.” (Entrevistado 4)

Acreditamos, também, que essa relutância seja influenciada pelo contexto social brasileiro das últimas décadas. No cenário nacional há medidas que podem influenciar a opinião dos entrevistados, uma delas foi a aprovação da Lei ${ }^{\circ}$ 12.288/2010 ( Estatuto da Igualdade Racial) e a votação no Supremo Tribunal Federal-STF sobre a constitucionalidade do sistema de cotas da Universidade de Brasília. Ao votar pela sua constitucionalidade, o STF sinalizou que, no aspecto legal, não há barreiras para se implantar tal sistema nas instituições de ensino superior no Brasil. Seguiu-se a esta decisão, a afirmação da constitucionalidade das cotas raciais e sociais do Programa Universidade para Todos-Prouni do Governo Federal para a rede de ensino superior pública e privada. $\mathrm{O}$ debate que antecedeu a aprovação do Estatuto da Igualdade Racial, tanto no espaço político quanto na sociedade de forma geral, ampliou a análise sobre a questão racial no país.

Os entrevistados são servidores que atuam no ciclo de formulação, implementação e avaliação de políticas públicas. São pessoas que estão acompanhando direta ou indiretamente essas discussões. Todos os vinte e um entrevistados disseram conhecer de alguma forma políticas de promoção da igualdade racial. Quer seja porque já trabalharam com essas ações, direta ou indiretamente; ou porque já trabalharam com pessoas envolvidas 
nessa área, ou pela mídia que explorou o assunto. Nesse aspecto, Norvell (2001) afirma que o discurso da classe média brasileira reflete uma consciência da crítica ao racismo no plano mundial (NORVELL, 2001:260).

Recorremos a uma problematização que Fraser (2007) faz sobre o porquê que algumas diferenças sociais não geram reivindicações, como a aqui discutida, a pessoa ser branca. Fraser afirma que geralmente as pessoas brancas não reconhecem a sua particularidade dado que são considerados padrões de dominação (vimos anteriormente o embate entre Fraser e Honneth sobre essa questão). Nesse cenário, como há uma discussão sobre a questão racial no Brasil e no mundo, parece desprovido de bom senso declarar-se desta ou daquela cor e/ou raça. Um participante on-line nos respondeu:

\footnotetext{
Não me considero e também não considero meus pais pertencentes a qualquer Raça (destaque do participante), pois julgo que esta classificação serve bem a criadores de animais, sendo assim, acho que a classificação das pessoas em "Raças" (destaque do participante) induz a um raciocínio diferenciador que reafirma preconceitos, que servem a uma ideologia de diferenciação das pessoas para manter privilégios". (Comentário via e-mail)
}

Essa opinião de que a declaração de cor e/ou raça pode levar a alguma vantagem por parte daquele que se declara, apareceu nesta pesquisa. Além do comentário acima, o Entrevistado 11 nos afirmou:

Toda e qualquer ação política do Estado, toda e qualquer política pública que seja interpretada pela sociedade como um benefício que é de direito, não importa se é de fato, basta que a interpretação seja, ela vai adotar a política como dela e vai dar sustentação política. (Entrevistado 11)

Nessa entrevista, o participante estava argumentando sobre a autodeclaração como opção para identificar o público alvo das políticas de promoção da igualdade racial. $\mathrm{O}$ argumento era que a pessoa tentaria usar uma condição que possivelmente não seria dela, apenas para fazer uso de um benefício posto pelo Estado para segmentos específicos.

A Entrevistada 7 complementou esse argumento dizendo que: 
Políticas de igualdade racial eu acho que têm um problema grande que é definir quem é negro e quem não é. Eu acho a autodefinição, digamos assim, a autodefinição pode te levar a situações ridículas, literalmente, como a que você vê agora na atual novela das 7 'Sangue bom' em que a atriz, mãe de um menino que ela supostamente adotou porque ele era negro. $\mathrm{O}$ menino é branco, muito mais branco que eu, e ela quer incutir uma identidade de negro na criança. Claro estamos falando de novela (...) Mas eu não sei como a gente poderia implementar políticas de cotas raciais sem permitir essa brincadeirinha da mulher da novela, de que você é negro, entendeu? É esse o meu maior problema. (...) O meu problema é a gradação, onde você corta, se a definição do negro sou eu que me identifico, eu não concordo. Porque num país de espertos, muita gente vai começar a se definir como negro, como índio, como qualquer coisa. (Entrevistada 7)

A questão para essa pessoa entrevistada era se os não negros ${ }^{46}$ iriam se sentir tentados a se declararem como pretos ou pardos para se beneficiarem de alguma política que favorecessem exclusivamente a população negra? Para Almeida e Young (2007), não. A Pesquisa Social Brasileira que estes autores conduziram testa os entrevistados, perguntando se as pessoas mudariam de cor em razão das políticas de cotas. Numa amostra dividida, split ballot, com o mesmo perfil de renda, sexo, escolaridade, idade, região de moradia, os autores concluem que as políticas de cotas pró negros não levam os entrevistados a escurecerem a sua autodeclaração de cor. Uma das razões segundos os autores é a forte reação que viria no caso de uma falsa declaração e de que há um consenso dos brasileiros sobre os critérios de classificação entre brancos, pardos e pretos.

A ideia da teoria de escolha racional é possível de ser aplicada como uma contraargumentação às conclusões de Almeida e Young (2007). Essa teoria defende que as pessoas são autointeressadas e racionais e que portanto iriam tentar maximizar ao máximo as suas vantagens e benefícios. No caso das políticas de promoção da igualdade racial, as pessoas tenderiam a se escurecer para serem beneficiadas num processo de seleção que objetiva identificar e atrair pessoas negras. Mas, acreditamos que aqueles considerados oportunistas seriam numericamente inexpressivos ou, em outros termos, não haveria significância estatística, algo como uma margem de 5\% (GUIMARÃES, 2005). Pouco expressivo a ponto de não comprometer os resultados dessas políticas. Houve relatos na experiência da Universidade de Brasília de pessoas tomarem sol para ter a pele mais escura, não alisar o cabelo ou colocar tranças rastafári, alguns artifícios que poderiam levá-las a serem imputadas como negras. Aí é que está, como há uma imputação do outro em relação a si mesmo, essas

\footnotetext{
${ }^{46}$ Algumas políticas de promoção da igualdade racial incluem como beneficiários não somente os negros, mas os indígenas também. As ações afirmativas para o ingresso no ensino superior são exemplos desse caso.
} 
pessoas necessariamente em algum momento de sua vida acadêmica ou profissional seriam colocadas contra a parede.

A preocupação de alguns dos nossos entrevistados vai mais na direção de uma possível fraude beneficiar aqueles que não são negros do que na utilização do termo cor ou raça como um ato racista.

De fato, a questão sobre a utilização da raça como uma atitude racista é intensamente discutida na literatura. Alguns entendem essas ideias como equivocadas e simplistas, pois acabam racializando a cultura social (APPIAH, 1997; GILROY, 2007). Outros defendem que raça é um conceito sociológico, numa tentativa de retirar a sua fundamentação biológica que, no caso brasileiro, varreu a teoria das relações sociais no final do século XIX e começo do século XX (GUIMARÃES, 1999).

Seguimos com Guimarães sobre a importância do desenho de uma política pública que quer ser eficaz. Guimarães defende que "torna muito difícil imaginar um modo de lutar contra uma imputação ou discriminação sem lhe dar realidade social" sobretudo no campo da política onde "os fatos a se combater precisam realmente ser fenomênicos para serem reais" (GUIMARÃES, 1999:25).

Um outro entrevistado identificou a ambiguidade das categorias utilizadas no estudo. Disse:

Eu sou afrodescendente, mas eu não sou completamente preto. Eu sei que a minha descendência remonta lá do Joaquim Barbosa, porque a fazenda era do meu avô, mas com a morte do meu tataravô, ele assumiu um caso que ele tinha com uma escrava. Eu sou afrodescendente, isso eu sei, eu não sou totalmente negro, também não poderia me dizer branco. Então eu sou pardo (...) Quando eu disse que eu era afrodescendente no início do governo Lula, meu chefe veio me questionar: 'pô, seus filhos são loiros', eu falei ‘todo negão, que é negão procura uma loira para casar, eu procurei a minha'. Ele falou 'você não é negro e eu falei, eu sou, eu lhe provo que eu sou. (Entrevistado 15)

O Entrevistado 11 também nos deu uma ideia sobre como se posicionam alguns quando se trata do pertencimento racial: "meu pai era branco e minha mãe é indígena. Eu acho que eu sou confuso (risos). Eu me declararia branco. Mas por sorte, por azar, eu tenho sobrinhos que são caboclos”. 
Os aspectos que pudemos identificar na fala dos nossos entrevistados são coerentes com aqueles apreendidos da literatura sobre relações raciais no Brasil. Primeiro, a atuação da ideologia de democracia racial que perpassa a sociedade brasileira - as relações das três raças, exemplo para o mundo, pois todos são iguais e não há diferenças essenciais entre brancos, negros e índios. Segundo, a ambiguidade na classificação racial no Brasil. Lívio Sansone já nos afirmava em 1996 que a resposta sobre cor são influenciadas pelo discurso de democracia racial e pela celebração da mestiçagem. Terceiro, como já mencionamos, o desconforto quanto a se afirmar como branco e discutir os benefícios e vantagens de pertencer a essa condição no Brasil (Norvell, 2001).

Seria tentador simplesmente afirmar que as narrativas desses servidores caracterizam a sociedade brasileira, se não no seu todo, pelo menos em parte. Mas, ser negro, pardo ou branco no Brasil pode depender ainda da condição socioeconômica do indivíduo que fala e que é visto. Mesmo quando se considera ora a autoclassificação, ora a heteroclassificação, a pessoa vai ser considerada negra a depender também da sua aparente condição social e econômica (MARTELETO; VERONA; RODRIGUES, 2007; SANSONE, 1996; SIMÕES; JERONYMO, 2007). Almeida e Young (2007), entretanto, defendem que o contexto social não muda a identificação racial das pessoas em uma classificação atribuída por outro, para esses autores por mais que nós achássemos que o Entrevistado 8 era branco, essa categorização não mudaria devido ao ambiente social em que o mesmo se encontra, há uma compatibilidade no que nós entrevistadores treinados enxergamos e o que a sociedade poderia classificá-lo, como ele mesmo afirmou: “um Estado onde há uma população negra muito grande eu era o branquinho".

Osório (2003) esclarece que a ambiguidade está na categoria pardo, pois não há confusão em identificar quem é branco, preto e amarelo no Brasil. Esse autor afirma que a maioria dos brasileiros consegue se autoclassificar dentre as cinco categorias do IBGE. Ele faz essa afirmação embasado em pesquisas que tratam sobre as categorias cor e/ou raça do sistema de classificação adotado pelos órgãos públicos no Brasil. Os termos étnico-raciais não foram inventados pelo IBGE, são classificações já existentes antes do primeiro censo de 1872 que lançou mão das categorias que os brasileiros utilizavam no seu dia a dia (OSÓRIO, 2003). Este estudo não pretende discutir a ambiguidade racial no Brasil, entretanto, de maneira 
convergente com os autores, argumentamos que qualquer que seja a tendência brasileira, há uma propensão a se voltar para o gradiente mais claro da raça e/ou cor. Assim entre, aquelas pessoas que carregam menos traços negros externamente, haveria uma tendência em se declararem brancas. Uma entrevistada nos dá um exemplo ao ser indagada sobre como declararia a cor ou raça de sua mãe, ela diz: "parda, mas a identidade é de branca" (Entrevistado 7). Essa declaração repousa no que diz Guimarães (1999:22) que os fenótipos ganham sentido social por meio de crenças, valores e atitudes.

Mostramos que alguns entrevistados ressentiam que pessoas poderiam se beneficiar ao se escurecerem, o que estamos afirmando é que pelo contrário, há uma tendência no sistema de triangulação brasileiro, branco, pardo e preto, das pessoas preferirem o continuum mais claro gradativamente dentro de um espaço específico - ou seja, se declararem mais claras do que são (SANSONE, 1996). Se as pessoas começam agora a se escurecer, supondo visar algum benefício, é um fato que mereceria ser estudado, pois apesar de Soares (2008) discutir a composição racial da população brasileira de 1890 a 2007, não há estudos empíricos ainda de classificação racial no Brasil que leve em consideração a mudança da cor/raça em razão de benefícios socioeconômicos. Soares (2008) analisando dados demográficos de 1890 a 2007 disponíveis nos Censos e na Pesquisas Nacionais por Amostra de Domicílio afirma que a população brasileira começou a enegrecer a partir de 1940 com um forte aumento de 2001 a 2007. O pesquisador aponta três causas, a taxa de fecundidade mais alta entre as mulheres pretas e pardas; segunda, a identificação racial da criança ao nascer com o crescimento dos pardos, portanto, dos negros, em razão do efeito de miscigenação; terceira, a mudança na identificação racial, ou seja, menor temor das pessoas se assumirem como negras.

Não há como se pensar em aliar termos burocráticos e científicos para se identificar quem é negro e quem não é. Quem seriam os beneficiários? O movimento social negro brasileiro defende o uso do termo cor e/ou raça muito propriamente, por mais que estudiosos discutam o problema da classificação racial não porque sejam favoráveis a políticas de promoção da igualdade racial (SANTOS, 2009), mas, apenas, como mais um obstáculo científico a ser travado e solucionado sobretudo pelas pessoas que são defensoras dessas políticas como provoca Cavalcanti-Schiel (2007), autor contrário a instituição de cotas raciais no ensino superior. 
Mesmo que haja alguma controvérsia problematizada pelos nossos entrevistados, a categoria cor e/ou raça é essencial para o desenho das políticas públicas. O conceito de raça de maneira não racista, como defende Guimarães (1999), é um dado que já existe. Reflete o que se encontra no cotidiano e no senso comum do brasileiro. Como é possível qualificar quem será o nosso público alvo em determinadas políticas públicas se não há essa identificação mais objetiva, por mais que a julguem subjetiva. Nossa postura nesse trabalho é utilizar cor e/ou raça conforme o senso comum. Acreditamos sim, como discute Guimarães (1999), que as pessoas ao atribuírem cor a outras pressupõe uma ideologia racial trazida de tempos muito recentes. Quijano (2000) ao discutir raça como uma categoria mental da modernidade nos leva a refletir que raça no seu sentido moderno é um conceito relativamente recente, não há registro na história das Américas antes da sua colonização. A relação colonizado e colonizador fundou-se sob uma ideia de raça e identidades sociais racializadas que tinham conotação hierárquica, espaços geográficos e funções sociais (QUIJANO, 2000:202). Segundo esse mesmo autor, o colonizador caracterizou cor a partir dos fenótipos dos seus colonizados que foi assumida como uma representação da categoria racial.

A Universidade de Brasília no seu processo de seleção de estudantes negros para o vestibular instituiu uma comissão que verificava se a declaração feita pelo estudante era verdadeira. A discussão recaiu sobre o respeitar a liberdade individual, que a cor e/ou raça de uma pessoa é imputação particular, mesmo que seja resultado de interações externas: porque a minha mãe ou pai é preto, porque alguém dizia que eu era preta, morena....enfim... Não acreditamos que isso seja verdadeiramente um problema para a implantação de políticas de promoção da igualdade racial porque as pessoas sabem quem é negro e quem não é nas suas relações sociais. Acreditamos que num primeiro momento, da sua implantação, as políticas de cotas receberam uma reação até desafiadora por parte daqueles que se sentiram excluídos em razão da cor da pele ou do pertencimento racial. Agora, as políticas de cotas raciais nas universidades já se consolidaram social e juridicamente. Se há os que passaram sem realmente serem, são poucos, insignificantes, os 5\% conforme discute Guimarães (2005). Mesmo se fosse possível conseguirmos critérios mais objetivos, isso não reduziria a possibilidade de fraude como sabemos que ocorre em políticas que têm como critério a renda (um dado supostamente objetivo) do possível beneficiário, como afirma Guimarães (2005). 


\subsubsection{Sexo e faixa etária}

A Tabela 13 nos apresenta a distribuição por sexo dos participantes desta entrevista. Vemos que todas as carreiras são predominantemente masculinas. Há um destaque nas carreiras de Analista de Planejamento e Orçamento e de Técnico de Pesquisa e Planejamento do Ipea. Esses percentuais não são distantes dos dados mais gerais sobre essas carreiras conforme apresentado na Tabela 10 .

Tabela 13 - Percentual de participantes das carreiras selecionadas por sexo

Carreiras

Advogado da União

Analista de Planejamento e Orçamento

Especialista em Políticas Públicas e Gestão Governamental

Procurador Federal

Técnico de Pesquisa e Planejamento do Ipea

Fonte: Dados primários - Elaboração da própria autora

\section{Sexo}

Feminino Masculino

$40 \quad 60$

$21 \quad 79$

$40 \quad 60$

$39 \quad 61$

$24 \quad 76$

A concentração por faixa etária dos servidores que participaram da pesquisa é semelhante ao dado mais geral (Tabela 10). Uma concentração grande na faixa dos 31 a 50 anos. Um dado que difere do retrato geral dessas carreiras é a proporção de jovens, as carreiras jurídicas são as mais jovens (no geral, é a carreira dos EPPGGs), com uma concentração de servidores na faixa etária dos 31 a 40 anos (Tabela 14). Chama atenção ainda a carreira do Ipea, entre os participantes da pesquisa, mais de $10 \%$ têm acima de 60 anos.

Tabela 14 - Percentual de participantes das carreiras selecionadas por faixa etária

\begin{tabular}{|c|c|c|c|c|c|c|}
\hline & \multicolumn{5}{|c|}{ Carreiras } & \multirow{2}{*}{ Total } \\
\hline & Adv.União & APO & EPPGG & Procurador & TPP_Ipea & \\
\hline Até 30 anos & $6,4 \%$ & $17,3 \%$ & $14,2 \%$ & $11,8 \%$ & $7,9 \%$ & $11,7 \%$ \\
\hline 31 a 40 anos & $52,6 \%$ & $30,7 \%$ & $42,5 \%$ & $54,8 \%$ & $44,7 \%$ & $48,2 \%$ \\
\hline 41 a 50 anos & $28,7 \%$ & $33,3 \%$ & $26,7 \%$ & $22,9 \%$ & $28,9 \%$ & $26,3 \%$ \\
\hline 51 a 60 anos & $9,4 \%$ & $14,7 \%$ & $15,0 \%$ & $9,6 \%$ & $7,9 \%$ & $11,5 \%$ \\
\hline Mais de 60 anos & $2,9 \%$ & $4,0 \%$ & $1,6 \%$ & $0,9 \%$ & $10,5 \%$ & $2,2 \%$ \\
\hline
\end{tabular}

Fonte: Dados primários - Elaboração da própria autora 


\subsubsection{Interpretação da origem social}

Para analisarmos a origem social dos participantes deste estudo, optamos por trabalhar com uma versão mais condensada da escala socioeconômica dividida em seis estratos ocupacionais elaborado por Pastore e Silva (2000) conforme relatado no capítulo anterior: (1) Baixo-inferior; (2) Baixo-superior; (3) Médio-inferior; (4) Médio-médio; (5) Médiosuperior; e (6) Alta. Reduzimos as categorias para estrato Baixo - trabalhadores rurais não qualificados, urbanos não qualificados, não manuais, profissionais de nível baixo e pequenos proprietários; Médio - trabalhadores não manuais, profissionais de nível baixo e pequenos proprietários e profissionais de nível médio e médios proprietários; e Alto - agregação dos trabalhadores de nível superior e grandes proprietários ${ }^{47}$. Acreditamos uma versão reduzida facilita a exposição, as conclusões e oferece uma visão panorâmica dos dados.

Nos casos onde havia a mesma ocupação, por exemplo comerciante, o nível de instrução condicionava a classificação no estrato de maior ou menor nível. É importante considerarmos o nível de instrução como um determinante da posição social e econômica do indivíduo, sobretudo no Brasil onde, ao contrário de muitos países europeus e dos Estados Unidos, os ganhos de retorno por meio da escolaridade são altos. Qualquer indivíduo que tiver um ano a mais de escolaridade tem um rendimento financeiro superior entre $15 \%$ a $20 \%$ do que aqueles que não o têm (PNAD, 2007), enquanto que a taxa de retorno individual com educação nos países da $\mathrm{OCDE}^{48}$ é cerca de 3\% a $6 \%$ (OCDE, 2006). Dado que o ensino fundamental é obrigatório - mesmo que num passado recente, a promulgação da Lei de Diretrizes e Bases da Educação em 1996 -, consideramos para essa análise a formação em estudos mais avançados como o ensino médio e superior.

Inspiramo-nos também no trabalho de Alves e Soares (2009) que interpretam uma escala de nível socioeconômico por meio de quintis de sua distribuição. Aqui nos propomos a trabalhar

\footnotetext{
${ }^{47}$ Os estratos ocupacionais expandidos e as ocupações representativas em que baseamos a versão reduzida encontram-se em Pastore e Silva (2000:21)

${ }^{48}$ Organização para Cooperação e Desenvolvimento Econômico (OCDE). Dado disponível em Education at a Glance: OECD Indicators - 2006 Edition. Disponível em: http://www.oecd.org/dataoecd/31/34/37393599.pdf. Acesso em: 20 ago. 2008; Os países membros da OCDE são: Alemanha, Austrália, Áustria, Bélgica, Canadá, Coréia, Dinamarca, Espanha, Estados Unidos, Finlândia, França, Grécia, Hungria, Irlanda, Islândia, Itália, Japão, Luxemburgo, México, Noruega, Nova Zelândia, Países Baixos, Polônia, Portugal, Reino Unido, República Eslovaca, República Tcheca, Suécia, Suíça e Turquia.
} 
com o quartil de distribuição do nível socioeconômico dos nossos participantes. No aspecto geral, vemos que na nossa pesquisa mais de $42 \%$ dos pais/mães (consideramos o maior status do pai ou da mãe) possuíam o ensino superior completo e mais de $22 \%$ possuíam pósgraduação, portanto, $65 \%$ tinham nível superior de ensino. Há uma grande frequência nos quartis da categoria ensino superior completo, no terceiro quartil, por exemplo, há uma maioria considerável de 71\% com curso de nível superior (Tabela 15).

Tipicamente, podemos dizer que os nossos participantes advêm de uma família cujo/a o pai/mãe possui nível superior, $71,6 \%$ possuem nível superior completo ou $21,1 \%$, pósgraduação (Tabela 15). Os responsáveis (pai ou mãe) estariam situados em um estrato ocupacional mais alto com profissões como engenheiros, servidores públicos de nível superior, comerciantes, advogados, médicos (Tabelas A8 e Tabela A9, Anexo A). Há uma grande frequência de pessoas de cor e/ou raça branca, uma característica presente em todos os quartis (Tabela 15).

Por outro lado, analisando os dados em cada distribuição, chamamos atenção para o primeiro quartil da categoria de pais/mães que estudaram até a $4^{\mathrm{a}}$ série do ensino fundamental, onde $29 \%$ estão nessa condição (Tabela 15). Essa leitura pode ser feita para o estrato ocupacional e cor/raça. Nessa distribuição se encontram famílias cujos responsáveis exerciam ocupações de estratos mais baixos $(51,8 \%)$ e onde há uma maior frequência de pardos em relação aos demais quartis. No segundo quartil, há uma frequência alta de pais/mães que concluíram o ensino médio $(24,3 \%)$ e começam a despontar aqueles/as que terminaram o ensino superior $(41,7 \%)$.

No terceiro e o quarto quartil, há uma frequência alta daqueles que possuem grau elevado de instrução com destaque para o quarto quartil com 46,5\% dos responsáveis com pósgraduação. Nesses mesmos quartis encontram-se uma enorme concentração de responsáveis em ocupações do estrato mais alto (99\% e 100\%). Acompanha essa leitura a cor e/ou raça, uma alta frequência de pais/mães brancos. 


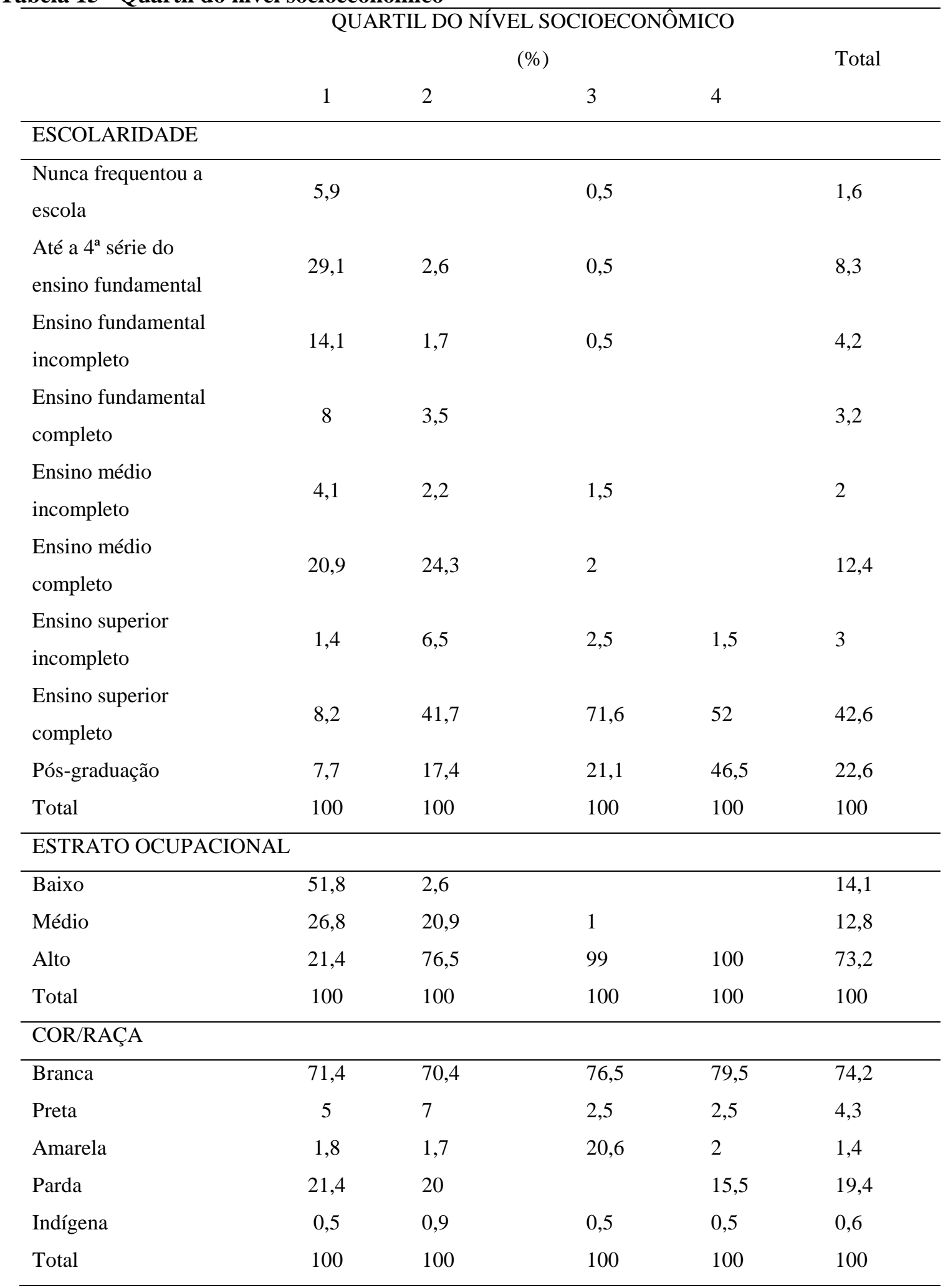

Fonte: Dados primários - Elaboração da própria autora, 2014 


\subsection{Os participantes entrevistados}

Como dissemos os participantes entrevistados foram selecionados aleatoriamente. Conseguimos entrevistar 21 servidores das Carreiras Típicas de Estado, conforme a apresentação do perfil dos nossos entrevistados apresentados no Quadro A1 (Anexo A), conversamos com quatro servidores da carreira de Advogado da União, cinco Analistas de Planejamento e Orçamento, seis Especialistas em Políticas Públicas e Gestão Governamental, dois Técnicos de Planejamento e Pesquisa do Ipea, quatro Procuradores Federais.

A maioria dos entrevistados declarou-se como sendo de cor e/ou raça branca, sendo também esta a predominância entre os pais e mães desses participantes. Houve um entrevistado que se pronunciou como cor e/ou raça não declarada. Da mesma forma que os participantes que responderam ao questionário on-line, 80\%, a formação universitária dos nossos entrevistados está concentrada na área de ciência sociais aplicadas como economia, direito, administração de empresas, arquitetura e urbanismo; e ciências contábeis ${ }^{49}$. A carreira jurídica puxa a formação para a área de ciências sociais aplicadas, pois todos aqueles que se candidatam a essa carreira, devem necessariamente ser graduados em direito. A área de pósgraduação dos entrevistados também acompanha a área da graduação, ou seja, ciências sociais aplicadas. Os pais ou mães de oito entrevistados não possuíam o curso superior completo. A maioria da ocupação dos pais e das mães dos entrevistados se situava num estrato alto.

A maioria dos entrevistados não exercia cargo em comissão no momento da entrevista, mas conseguimos conversar com pessoas que exerciam diferentes níveis de DAS, do nível dois ao nível cinco. Grande parte já teve alguma experiência em gestão, pois haviam exercido cargo em comissão no período de 2007 a 2012. No momento da entrevista, os participantes trabalhavam em diversas áreas de atuação do Estado: social, infraestrutura, econômica, planejamento, regulação e advocacia pública.

\footnotetext{
${ }^{49}$ Conforme classificação das áreas de conhecimento adotada pela Coordenação de Aperfeiçoamento de Pessoal de Nível Superior-Capes: http://www.capes.gov.br/avaliacao/instrumentos-de-apoio/tabela-deareas-do-conhecimento-avaliacao
} 
Como mencionamos anteriormente, entrevistamos também cinco ex-dirigentes de políticas de promoção da igualdade racial no governo federal. Esses dirigentes trabalharam no governo FHC e no governo Lula. Aqueles que se encontravam fora de Brasília, realizamos a entrevista por telefone. Conforme Quadro 2, os cinco dirigentes são do sexo masculino, um dos dirigentes declarou sua cor e/ou raça como branca e os demais preta. Os dirigentes entrevistados possuíam experiência gerencial na administração pública antes de assumirem a condução das políticas de promoção da igualdade racial no governo federal. Em geral, os entrevistados possuíam mais de 20 anos de experiência na administração pública. Um dos dirigentes possuía também experiência política com o exercício de cargo eletivo. Os nossos entrevistados provinham de um estrato social baixo cujos pais exerciam posições ocupacionais inferiores o que poderia ser um reflexo da sua formação educacional. Os pais e as mães dos dirigentes não possuíam nível superior. O grau máximo de instrução encontrado foi o nível médio, havendo três dirigentes cujos pais e/ou mães nunca haviam frequentado a escola (Quadro 2). 
Quadro 2 - Perfil sociodemográfico dos dirigentes de políticas de promoção da igualdade racial entrevistados -2014

\begin{tabular}{|c|c|c|c|c|c|}
\hline Dirigentes & 1 & 2 & 3 & 4 & 5 \\
\hline $\begin{array}{l}\text { Formação } \\
\text { Superior }\end{array}$ & Arquitetura & Letras & $\begin{array}{l}\text { Zootecnica e } \\
\text { Direito }\end{array}$ & $\begin{array}{l}\text { Ciências } \\
\text { Sociais }\end{array}$ & $\begin{array}{l}\text { Química e } \\
\text { Ciência } \\
\text { Política }\end{array}$ \\
\hline Nascimento & 1952 & 1952 & 1959 & 1954 & 1952 \\
\hline Cor/Raça & Preta & Branca & Preta & Preta & Preta \\
\hline $\begin{array}{l}\text { Pós- } \\
\text { graduação }\end{array}$ & Não & $\begin{array}{l}\text { Doutorado em } \\
\text { Comunicação } \\
\text { Social }\end{array}$ & $\begin{array}{l}\text { Mestrado em } \\
\text { Transportes } \\
\text { públicos }\end{array}$ & Não & $\begin{array}{l}\text { Doutorado em } \\
\text { Sociologia }\end{array}$ \\
\hline Cor/Raça Pai & Preta & Branca & Preta & Preta & Preta \\
\hline $\begin{array}{l}\text { Cor/Raça } \\
\text { Mãe }\end{array}$ & Parda & Branca & Parda & Preta & Preta \\
\hline $\begin{array}{l}\text { Escolaridade } \\
\text { Pai }\end{array}$ & $\begin{array}{l}\text { Fundamental } \\
\text { Incompleto }\end{array}$ & Ensino médio & $\begin{array}{l}\text { Nunca } \\
\text { frequentou a } \\
\text { escola }\end{array}$ & $\begin{array}{l}\text { Nunca } \\
\text { frequentou a } \\
\text { escola }\end{array}$ & Ensino Médio \\
\hline $\begin{array}{l}\text { Escolaridade } \\
\text { Mãe }\end{array}$ & $\begin{array}{l}\text { Nunca } \\
\text { frequentou a } \\
\text { escola }\end{array}$ & $\begin{array}{l}\text { Ensino médio } \\
\text { incompleto }\end{array}$ & $\begin{array}{l}\text { Nunca } \\
\text { frequentou a } \\
\text { escola }\end{array}$ & $\begin{array}{l}\text { Nunca } \\
\text { frequentou a } \\
\text { escola }\end{array}$ & Ensino Médio \\
\hline Ocupação Pai & $\begin{array}{l}\text { Policial } \\
\text { Militar,Sapate } \\
\text { iro, } \\
\text { Carcereiro }\end{array}$ & Escriturário & Lavrador & $\begin{array}{l}\text { Artífice de } \\
\text { manutenção }\end{array}$ & Motorista \\
\hline $\begin{array}{l}\text { Ocupação } \\
\text { Mãe }\end{array}$ & $\begin{array}{l}\text { Doméstica } \\
\text { Colchoeira }\end{array}$ & $\begin{array}{l}\text { Dona de casa } \\
\text { e } \\
\text { Secretária } \\
\text { Executiva }\end{array}$ & Lavradora & Doméstica & Dona de casa \\
\hline
\end{tabular}

Fonte: Dados primários - Elaboração da própria autora ,2014 


\section{Capítulo 4 - O papel da alta burocracia técnica}

Burocracia, poder gigante colocado em
movimento por anões ${ }^{50}$.

Honoré de BALZAC

A apresentação dos participantes deste trabalho no terceiro capítulo nos traz uma ideia sobre o perfil dos servidores que trabalham no ciclo de políticas públicas do governo federal. Sobretudo das carreiras do Poder Executivo que possuem dentro da sua regulação profissional a atuação em formulação, implementação e avaliação de políticas públicas. Os dados são úteis para relacioná-los aos propósitos deste capítulo.

Aqui discutiremos a autonomia do servidor à luz da teoria da burocracia representativa e weberiana; o papel dos servidores no processo de tomada de decisão e o que pensam os nossos participantes sobre a sua própria atuação nas decisões da administração pública.

\subsection{Burocracia representativa}

É bem possível nos perdemos quando olhamos para o Estado brasileiro. A tentativa de definir o que é, quem é quem, quem influencia quem ou o que influencia o que é um grande desafio. O sistema de checks and balances $^{51}$ dos poderes de Montesquieu nos dá uma pista por onde podemos começar. Os poderes legislativo, executivo e judiciário controla, fiscaliza e equilibra as relações no Estado. Se descermos um pouco mais na estrutura de cada um dos poderes, veremos que há órgãos, departamentos, unidades que se entranham na tentativa de tecer uma teia minuciosamente conectada.

Nesse espaço atuam de forma técnica e administrativa pessoas - a burocracia estatal. Uma categoria que se aproxima da definição weberiana de Estado que tem na burocracia o seu

\footnotetext{
${ }^{50}$ La bureaucratie, pouvoir gigantesque mis en mouvement par des nains.

${ }^{51} \mathrm{O}$ conceito de checks and balances ou sistema de freios e contrapesos se baseia no princípio da separação de poderes para que haja a liberdade política por meio do estabelecimento de controle dos poderes no âmbito das suas funções específicas. Assim, os ramos do governo têm a sua função separada e distinta, fazer leis, executar ações públicas e julgar.
} 
meio de dominação. Uma dominação legítima, se pensarmos em um Estado de bases racional-legal. Um Estado que "descansa sobre um funcionalismo especializado e um direito racional" (WEBER, 1999:518). Esse conceito de burocracia foi perseguido pela reforma administrativa do Estado Novo nos anos de 1930. O sonho da objetividade, impessoalidade e racionalidade do Estado como uma forma de se contrapor ao patrimonialismo existente na Administração Pública (FARAH, 2011; LOUREIRO, ABRUCIO; PACHECO, 2010a).

Para Weber (1993) a burocracia moderna se distingue das burocracias das civilizações antigas como da China, do Egito, do Império Romano e do Bizâncio. Para o autor essas burocracias eram formas irracionais de burocracia, "o velho mandarim chinês não era um funcionário profissional, mas, ao contrário, era um aristocrata de formação literária e humanista" (WEBER, 1993). O funcionário egípcio, do fim do império romano e bizantino, poderia ser considerado um burocrata no sentido weberiano, mas as suas atribuições "eram ligadas a tradições patriarcal, portanto, orientada irracionalmente" (Weber, 1993:52).

A teoria da burocracia representativa não se alinha com a defesa de Weber ao afirmar que o servidor público não deve entrar na área política. Para Weber há uma objetividade da burocracia estatal que é controlada de cima para baixo onde o burocrata deve conservar a imparcialidade e desprezar as suas inclinações e opiniões no exercício de suas funções; deve aderir ao programa político estabelecido mesmo que não corresponda a suas próprias atitudes políticas (Weber, 1993:45).

Kingsley (1944), precursor da teoria sobre burocracia representativa, delimita questões sobre o papel e as caraterísticas da burocracia face a população em geral. As proposições que norteiam a teoria da burocracia representativa são entender se a burocracia simboliza instituições; se representa a população nacional, ou parte dela, quanto a suas preferências e interesses políticos, ideologias, características demográficas como raça, etnia, gênero e classe social. Questiona também se a representação descritiva ou passiva (a presença de indivíduos de uma dada categoria sociológica) poderia levar a uma representação substantiva ou ativa (ações políticas que beneficiem a dita categoria sociológica). 
Kingsley defende que o burocrata tem a sua discricionariedade. Ele traz para o seu espaço de atuação a sua perspectiva particular, o seu conjunto de valores e a sua cultura própria. Apesar de não trazer dados empíricos, Kinglsley, ao fazer uma análise sobre a burocracia britânica, afirma que a burocracia pública é constituída maciçamente de pessoas das classes média e alta, nas palavras do autor, são pessoas educadas sob o paradigma da classe dominante. Quando Kingsley faz essa análise, ele está olhando para o Reino Unido da Segunda Guerra Mundial e analisando profundamente o Governo Churchill. Assim, no âmbito do contexto em que analisa e que produziu sua teoria, o autor defende que se a classe trabalhadora emergisse da guerra como a força dominante no Estado, o serviço público civil deveria ser reformado de baixo para cima. O autor afirma que "para a burocracia, ser mais democrática, deve ser representativa do grupo que serve" (KINGSLEY,1944:305).

Dolan e Rosenbloom (2003) acreditam que há uma controvérsia entre a análise que Weber faz da burocracia com a teoria da burocracia representativa proposta por Kingsley. Esses autores afirmam que na perspectiva weberiana o topo é que toma a decisão, pois o burocrata que atua em níveis médios e baixos teria pouca discricionariedade ou independência para representar qualquer pessoa ou representar interesses de qualquer grupo . "Um operário é um operário ( $a \operatorname{cog}$ is a cog - é apenas uma peça da engrenagem), independente de quem quer que seja democrata, republicano, negro ou branco, homem ou mulher, desta ou daquela região, se de família pobre ou rica" (DOLAN, ROSENBLOOM, 2003). Uma posição weberiana invocada por aqueles que acreditam que a burocracia não é uma instituição politicamente representada. Considerando os argumentos de Weber, uma burocracia representativa seria algo impossível porque essa burocracia idealizada pelos defensores da representação burocrática não tem interesse próprio, não influencia processos decisórios e nem tem papel importante e autônomo na estrutura da administração pública. Muitos pesquisadores contemporâneos, que adotaram a teoria da burocracia representativa de Kingsley, defendem o contrário. Acreditam que os burocratas individualmente podem ter um impacto significante nas escolhas administrativas e podem representar a população em geral ou grupos específicos (BRADBURY; KELLOUGH, 2008; BRUDNEY; HEBERT; WRIGHT, 2000; COLEMAN-SELDEN, 1998; DOLAN, 2002; DOLAN; ROSENBLOOM, 2003; KEISER et al, 2002; MEIER; NIGRO, 1976; MEIER; WRINKLE; POLINARD, 
1999; MOSHER, 1968; NAFF; CRUM, 2000; THEOBALD; HAIDER-MARKEL, 2009; THOMPSON, 1978; WINN, 1989).

Kingsley se aproxima da visão da não discricionariedade do servidor público propalada por Weber quando afirma que o corpo administrativo do Estado não está isolado de pressões sociais porque o burocrata não opera no vácuo social. A burocracia estatal não é um agente livre servindo aos seus próprios fins. A relação entre a burocracia, segundo o autor, traz benefícios como a aquisição da "sabedoria política " porque eles estão estreitamente em contato com os membros do parlamento e com a população em geral - portanto, com as pressões que diferentes grupos exercem (KINGSLEY,1944:206).

Mosher (1968) foi o autor que distinguiu conceitualmente representação ativa e representação passiva da burocracia. Primeiramente, Mosher associa a ideia de representatividade à responsabilidade subjetiva. $\mathrm{O}$ foco da responsabilidade subjetiva não é para quem ou para o que alguém é responsável (responsabilidades estabelecidas em normas legais ou organogramas institucionais), mas a quais grupos, ideologias propostas alguém está intrinsicamente responsável e comprometido. A responsabilidade subjetiva representa julgamento de valores pelos indivíduos (MOTTA; BANDEIRA, 2003), pesam, portanto, a origem social, os processos de socialização e associações realizadas dentro e fora da organização (MOSHER, 1968). Motta e Bandeira (2003), que analisam as reflexões sobre a responsabilidade na gestão pública quando praticados pelos servidores públicos, alertam que a responsabilidade subjetiva tem alta diversidade e pluralidade de valores na administração pública conforme o quadro de servidores.

Diferentemente, o conceito de responsabilidade objetiva representa as obrigações políticas e administrativas (MOTTA; BANDEIRA, 2003). Conceitualmente, segundo Mosher (1968), os fatores intrínsecos relacionados à responsabilidade subjetiva não influenciam a responsabilidade ou o compromisso de uma pessoa ou de uma organização para alguém ou para alguma coisa. A responsabilidade objetiva está fortemente relacionada à ideia de accountability - a capacidade de alguém responder por alguma ação, prevista nos processos formais de uma organização. O conceito de responsabilidade objetiva está imbuído da ideia 
de que o servidor público age com neutralidade e se submete às imposições governamentais, das leis e da vontade e preferência dos representantes eleitos (MOTTA; BANDEIRA, 2003).

Esses tipos de responsabilidades são categorias analíticas, pois na prática essas responsabilidades não são estanques, se mesclam e podem ser conflitantes conforme discutem Motta e Bandeira (2003). Esses autores exploram que os administradores públicos atuam em um espaço de demandas conflitantes e contraditórias, essas demandam pressionam pela hierarquização de valores. Ao mesmo tempo, os autores argumentam que o processo de formulação de políticas públicas e a sua implementação não emana de decisão individual de um único servidor; acreditam que a tomada de decisão passe por um processo coletivo de intensas interações pessoais onde se espera que haja algum grau de cooperação e compartilhamento de valores. Isto é, o servidor não está sozinho na tomada de decisão; o ambiente decisório é dinâmico e interativo onde um conjunto de atores e interesses empurram a decisão a ser tomada.

Pela ótica de Mosher (1968), a representatividade está relacionada conceitualmente à responsabilidade subjetiva. $\mathrm{O}$ autor procura definir a representatividade ativa e passiva. Espera-se que representatividade ativa em um servidor público expresse os interesses ou preferências daqueles a quem se presume que esse servidor represente seja a toda uma população ou a segmentos sociais específicos; isto é, há uma responsabilidade deste servidor em relação aqueles que ele representa. Esse autor denuncia que esse conceito de representatividade atenta contra o princípio de um governo democrático que atenda a todo e qualquer interesse que seja público.

A representatividade passiva está relacionada à origem dos indivíduos e ao quanto esses indivíduos espelham a sociedade como um todo. Mosher (1968) observa que a representatividade passiva pode ser mensurada estatisticamente como a ocupação profissional anterior, a ocupação do pai, nível de instrução, renda familiar, classe social, raça, religião, região de origem (rural ou urbana). O autor prescreve que um serviço público, e mais especificamente as lideranças de um serviço público, devem ser amplamente representativas de todas as categorias da população. Alerta também que não é só pelo fato de um servidor público possuir dadas origens sociais e características que ele representará 
os interesses daqueles com os quais se assemelha. Assim, necessariamente esse servidor não irá ter comportamentos e decisões que atendam aos interesses e preferências de grupos com os quais compartilha as mesmas origens sociais e características. Uma mulher atuando na administração pública não significa que irá tomar decisões que beneficiem diretamente e sejam do interesse das mulheres brasileiras, por exemplo. Da mesma forma, um servidor negro necessariamente não terá a responsabilidade subjetiva pelos interesses e benefícios da população negra. Isso corrobora o conceito de lugar epistêmico e lugar social defendido por Grosfoguel (2009). Esse autor afirma que o fato de alguém fazer parte de um grupo em situação de vulnerabilidade social não significa que pense a partir de um lugar epistêmico subalterno. O que pode ocorrer é pensar e agir como aqueles que se encontram em posições dominantes, agindo, portanto, segundo regras sociais dadas conforme discute Guimarães (2006) ao invocar a ideia de comportamento coletivo.

Mosher (1968) vai além, ele acredita que por mais que a representação passiva não seja um garantidor de tomadas de decisões democráticas, ela traz valores simbólicos que são significativos para uma sociedade democrática. Vejamos o programa de ação afirmativa do Ministério das Relações Exteriores para a carreira diplomática. O Ministério das Relações Exteriores instituiu em 2002 um programa "Bolsa Prêmio de Vocação à Diplomacia" destinado a candidatos negros. O programa tinha como meta atender ao desafio de tornar a diplomacia brasileira mais diversa conforme as palavras do então Presidente da República Fernando Henrique Cardoso ao anunciar a sua criação.

Serão concedidas 20 bolsas de estudos para afrodescendentes para que se preparem, especificamente para o concurso que haverá - como há todo ano - no Itamaraty. Precisamos ter um conjunto de diplomatas - temos poucos - que sejam o reflexo da nossa sociedade, que é multicolorida, e não tem cabimento que ela se apresente ao mundo afora como se fosse uma sociedade branca, porque não é. (Discurso na cerimônia de entrega do Prêmio Nacional dos Direitos Humanos em dezembro de 2001).

Atualmente, muitos autores contemporâneos afirmam que há uma relação entre as duas formas de representação passiva e ativa, geralmente elas são exploradas empiricamente por meio da análise dos quadros organizacionais e dos resultados das políticas implementadas (BRADBURY; KELLOUGH, 2008; BRUDNEY; HEBERT; WRIGHT, 2000; COLEMANSELDEN, 1998; DOLAN; ROSENBLOOM, 2003; KEISER et al, 2002; MEIER; WRINKLE; POLINARD, 1999). A relação entre essas duas formas de representação 
significa dizer que quando se constitui uma representação passiva - servidores que são o reflexo social da população - em determinado órgão governamental, tem-se uma representação ativa - servidores que atendem aos interesses daqueles que representa, mesmo não sendo o seu espelho sociodemográfico - na distribuição dos resultados das políticas públicas implementadas. No capítulo quinto, Iremos aplicar a teoria da burocracia representativa nos dados empíricos apresentados onde verificaremos as relações das variáveis que fundamentam este trabalho.

\subsection{A alta burocracia técnica (política) e seu espaço de atuação}

Segundo Weber (1999), no tipo ideal, a burocracia moderna é livre, obedece somente às obrigações objetivas de seu cargo; é nomeada e não eleita numa hierarquia rigorosa dos cargos; tem competências funcionais fixas; qualificação profissional verificada mediante prova e certificada por diploma. Os servidores da burocracia moderna são remunerados com salários fixos em dinheiro, na maioria dos casos com direito a aposentadoria; exercem seu cargo como profissão única ou principal; têm perspectiva de uma carreira; estão submetidos a um sistema rigoroso e homogêneo de disciplina e controle do serviço. Em termos weberianos a sociedade reconhece o domínio da burocracia pela sua capacidade técnicoadministrativa, da forma de ingresso no Estado e do grau de fidelidade à orientação superior. Levantamos uma questão, como, neste tipo de descrição weberiana se enquadra à burocracia que estudamos?

Podemos introduzir essa discussão com o trabalho de Loureiro e Abrucio (1999) ao criticarem o ideal de despolitização da burocracia. Esses autores analisam as nomeações para altos cargos governamentais no Ministério da Fazenda durante o primeiro governo Fernando Henrique Cardoso. Argumentam que as escolhas que a burocracia faz quando atua na administração pública não são neutras e ao mesmo tempo defendem um perfil técnicopolítico para a burocracia. Esse perfil consiste em servidores de alta qualidade técnica e capacidade de mobilização política. Ressaltam que até no Ministério da Fazenda, um espaço burocrático considerado eminentemente técnico, os burocratas precisam atuar politicamente. 
Godoy e Teixeira (2009) chegam à mesma conclusão ao analisar a lógica de relacionamento e circulação dos Especialistas em Políticas Públicas e Gestão Governamental na máquina estatal. Os autores trabalham com as gramáticas propostas por Nunes (2003) como categorias de análise da realidade brasileira: clientelismo, corporativismo, insulamento burocrático e universalismo de procedimentos. Outras categorias de análises com as quais Godoy e Teixeira (2009) trabalham são as definições dos burocratas que Schneider (1994) desenvolve: técnico e técnico-político. Godoy e Teixeira (2009) argumentam que os técnicos-políticos devem ser capazes de sacrificar a pureza burocrática em nome do apoio político. Mas, a discussão fundamental desses pesquisadores é que aqueles burocratas que desempenham um perfil técnico-político têm um poder estabelecido e a sua abrangência é muito maior do que os seus pares de perfil mais especialista.

Não encontramos evidência empírica da ideia de neutralidade weberiana na composição da burocracia do Estado brasileiro. Pressupomos que dificilmente o servidor público abrirá mão do seu ser político na atuação cotidiana da administração pública. Em algum momento o burocrata faz uso de seus valores, crenças, ideias que balizam a sua vida em sociedade. A objetividade no nosso entender não significa que os servidores públicos não tenham lados, posições ideológicas, postura partidária ou até mesmo pertençam a um partido com objetivo de alcançar o poder para legitimamente desenvolver bandeiras programáticas. Existe algum tipo de atuação política que não quer dizer necessariamente atender às diretrizes partidárias.

Mas, para nós o que significa atuar politicamente? Inicialmente, tomamos a categorização de técnico-político que foi utilizada pela primeira vez em um estudo por Schneider (1994) sobre como a burocracia da década de 1980 ajudou o país no seus projeto de industrialização. Os achados do autor sobre a burocracia que atuava nas áreas de planejamento, de infraestrutura e econômica o fizeram identificar quatro tipos de burocratas públicos: os políticos, os militares, os técnicos e os técnicos-políticos. Para Schneider (1994), os políticos procuram maximizar todas as oportunidades no espaço público que possam auxiliá-los eleitoralmente. Os militares voltam as suas preocupações para a segurança nacional. Os técnicos procuram alcançar a eficiência das políticas públicas por meio da racionalidade técnica. Já os técnicos-políticos "combinam características e preferências tanto dos políticos quanto dos técnicos, fazendo o papel de intermediários”. Os técnicos-políticos 
podem dar preferência a uma ou outra atitude (ou uma combinação delas), dependendo da situação” (SCHNEIDER, 1994:29-30). O autor entende que a diferença fundamental entre os técnicos e os técnicos-políticos é que estes últimos aceitam a interferência política como um fator necessário para que as decisões sejam tomadas.

O perfil técnico-político poderia ser o mais coerente para as carreiras tidas como típicas de Estado, ou seja, combinar capacidade de negociação, conhecimento técnico e articulação política. Porém, isso, no ponto de vista de algumas carreiras pesquisadas, só é possível para algumas delas. As carreiras jurídicas enxergam a necessidade de afastamento da política para o bom desempenho de suas funções, na defesa de uma carreira de Estado e não de Governo. Vejamos:

E essa é a discussão dentro da advocacia pública: se nós seríamos uma Advocacia de Governo que teria uma influência direta no mérito das políticas públicas ou se seríamos apenas uma Advocacia de Estado. Eu, entendo que o meu papel aqui é de Advocacia de Estado como descrito na Constituição. O meu papel não é influenciar o gestor nas decisões políticas, na condução da coisa pública. O meu papel é simplesmente indicar o melhor caminho dentro da legalidade, da constitucionalidade, obviamente, eu vou afetar as decisões da política pública (Entrevistada 5)

Um outro entrevistado compartilha da mesma opinião, parece considerar que há uma objetividade no trabalho que as carreiras jurídicas realizam:

\begin{abstract}
A Procuradoria Geral...ela não é Advocacia de Governo, ao contrário do atual pensamento da elite dominante da AGU (...) Nós praticamos uma Advocacia de Estado. Concomitante a isso, na verdade a concretização de políticas públicas. É algo indissociável (...) a função do Procurador é de defesa do Estado. Quando eu falo Estado é aquela pessoa jurídica impessoal. Aquela pessoa que tem como função propiciar a dignidade, o valor humano, ser um Estado democrático de direito, com o objetivo fundamental de servir a população de forma indistinta (..) Advocacia de Estado, aquela que é vocacionada com o objetivo de implementar ações, de defesa, de forma impessoal (Entrevistado 14)
\end{abstract}

O fazer política é inerente à função pública como podemos compreender a partir de Weber (1971). Esse pressuposto pode ser confirmado pela análise empírica de Vaz (2010) ao descrever o papel dos Advogados da União nas políticas públicas energéticas do Brasil. Vaz (2010) entrevistou, além de Advogados da União, dirigentes políticos da área energética que trabalharam com esse grupo de servidores. Nas palavras dos dirigentes entrevistados pela autora, o Advogado da União deve-se envolver no desenvolvimento da própria solução, não 
apenas manter uma postura distante analisando a matéria exclusivamente sob o aspecto jurídico, a legalidade e a constitucionalidade do ato.

Os mesmos dirigentes entrevistados, entretanto, reconhecem que na maioria das vezes a coisa não se dá dessa maneira. No caso analisado pela autora, houve impasses e dificuldades dos Advogados da União lotados na Consultoria Jurídica do Ministério de Minas e Energia. Eles geralmente participavam, discutiam, mas não queriam se comprometer oficialmente com as posições e conclusões adotadas. Alegavam que as razões para esse comportamento era o cumprimento do rito processual - a necessidade de haver um pronunciamento formal da área jurídica do órgão. Também, ressalta Vaz (2010), há o dilema entre o controle e o assessoramento jurídico, funções da Advocacia da União. Ao prestar o controle de uma ação, o Advogado da União deve se isentar em relação ao que avalia; ao prestar assessoramento jurídico, se compromete com a solução política e jurídica sobre a matéria. Portanto, podemos entender que há sempre uma margem para a autonomia e atuação política do servidor a depender da finalidade das suas funções. Se controla, procura manter uma distância do objeto analisado; se presta assessoria jurídica, imiscui a interpretação objetiva da norma e valores sociais internos.

Na pesquisa conduzida por Vaz (2010), o então Advogado-Geral da União, Luis Inácio Lucena Adams, ao comentar sobre a função de controle e de assessoria jurídica, explicita o grau de comprometimento que o servidor público poderia ter.

\footnotetext{
Nós apoiamos e orientamos os atos da administração, conformamos os atos da administração à legalidade. Esse procedimento é propositivo e opinativo, mas vem carregado de legitimidade técnica e moral. Essa dimensão de apoio, de suporte jurídico, do ponto de vista de percepção geral, aparentemente é menos relevante que a função de controle. Parece melhor essa última postura, porque aparentemente há mais força no "não faça" do que no "pode fazer de determinada maneira". E na verdade, é substancialmente diferente, porque o "não faça" é terminativo, é a opção pelo não. Por sua vez, o "faça dessa forma" é opinativo, não determinativo, mas é desbravador, porque estabelece soluções e caminhos; viabiliza as políticas pretendidas (VAZ, 2010:126).
}

O fato de trabalhar o tempo todo com a constitucionalidade de um ato, declarar legalidade ou não de um ato, leva a carreira jurídica a ter um discurso mais assertivo quanto a natureza de suas funções na dicotomia entre ser Governo ou ser Estado. Uma percepção que não tivemos das demais carreiras. Se o governo é eleito legitimamente reflete, portanto, a vontade da população, e se as propostas de políticas públicas são constitucionais e legais, 
não haveria razão para resistir em ter uma participação mais técnica-política dos membros das carreiras jurídicas. Mas, não é bem assim. Os dirigentes da política energética, que foram entrevistados por Vaz (2010), indicavam as dificuldades e impasses na relação com membros da carreira jurídica. Os dirigentes de políticas de promoção da igualdade racial também relataram dificuldades encontradas na relação com esses servidores durante a sua atuação como gestores:

Esse é um dos grandes entraves para a implementação de políticas públicas de ações afirmativas. A implementação do chamado Direito Positivo ou Direito Novo porque eles se valem exatamente do arcaísmo da estrutura jurídica brasileira para barrar qualquer possibilidade de avanço nesse campo (...) É a forma pela qual o Estado se exime da responsabilidade de cumprir com os compromissos com a sociedade, colocando eles (Advocacia-Geral da União, esclarecimento nosso) para agirem. Basta fazerem isso. Ainda criminalizam quem por ventura tente enfrentá-los (Dirigente 1).

Um outro dirigente expressa a seguinte percepção, fruto da experiência no Poder Executivo:

Durante o processo que trabalhamos para tirar um documento para aprovação do Estatuto da Igualdade Racial tivemos um parecerista do Ministério do Planejamento, Orçamento e Gestão (...) ele disse que a matéria do Estatuto da Igualdade Racial era uma matéria inconstitucional e não deveria ser aprovada, a Presidência não deveria levar adiante esse projeto de lei. Então, você "veja" que era um técnico da assessoria jurídica do Ministério do Planejamento, mas queria não aprovar o Estatuto da Igualdade Racial (...) e deve estar lá criando todos os óbices para se aprovar matéria de volume para ação afirmativa (Dirigente 3).

Para o então Advogado-Geral da União, Luis Inácio Lucena Adams, o processo de decisão é político, portanto, o Advogado da União deve ter vocação para ir além do âmbito estritamente jurídico e adentrar no mérito: “também tem que compreender que o papel de conformidade jurídica não é a decisão em si. A decisão é resultante de uma multiplicidade de fatores, de necessidades materiais, estratégicas, de planejamento, de limitações de meios. Essa complexidade é que se traduz numa opção, na política" (VAZ, 2010:126). Ainda, nas palavras do Advogado-Geral da União:

\footnotetext{
Muitos agentes não são vocacionados a esse tipo de desenvolvimento, outros mais, outros menos (O Advogado-Geral da União estava se referindo ao momento em que, como Consultor Jurídico, ajudou a elaborar o projeto da Parcerias Público-Privada-PPP comentário nosso). Mas a Instituição (a AGU, esclarecimento nosso) tem que ter essa vocação e acho que vem tendo, até porque está assumindo incumbência nova, que é a de conciliar esses conflitos, dirimi-los, para além do âmbito estritamente jurídico, alcançando o mérito também. Sob esse aspecto, creio que estejamos recebendo apoio mais intenso do Governo. (...). Grande parte da legitimidade política tem a ver com a sua legitimidade fática, material, ou seja, o momento em que a política é adotada, em determinada circunstância, pode ser lida como constitucional e, em outro, inconstitucional. $\mathrm{O}$ mesmo evento pode ter
} 
duas leituras totalmente diferentes. Como se diz: "o homem é o homem e suas circunstâncias". (VAZ, 2010:121).

Encontramos um Procurador Federal que trabalhava com comunidades quilombolas nos Estados. A manifestação de sua atitude nos fez pensar se o fato daquele servidor trabalhar tão proximamente de uma temática polêmica na sociedade brasileira e de estar baseado fora de Brasília não o tenha levado a vivenciar um processo de socialização profissional diferente. No âmbito da teoria da burocracia representativa, Meier e Nigro (1976) identificam que a socialização organizacional é o fator mais importante do que a composição demográfica para explicar atitudes dos burocratas. Coleman-Selden (1998) contrariamente, conclui que quando se trata de melhorar as condições das minorias, fatores demográficos (incluindo raça) são mais importantes do que a socialização organizacional. Vejamos o que o Procurador Federal entrevistado nos diz sobre o cargo que exerce:

\begin{abstract}
Ela (a Procuradoria Federal, esclarecimento nosso) sempre é consultada pela Superintendência com relação à implementação de políticas públicas, com relação à opção por desapropriar determinado imóvel rural a ser objeto da política pública da reforma agrária, então a Procuradoria costuma participar dessas decisões, ainda que de maneira só consultiva. (...) Em relação à política quilombola (...) embora a Constituição garanta uma série de direitos, mas como é da área de remanescentes de quilombos, dentro do próprio Estado ainda há embates e estes embates dentro do próprio Estado estão dificultando a realização da própria Constituição. Muito embora a Constituição traga direitos claros às comunidades quilombolas, há embates interno ao próprio Estado. E aí eu não falo só de Poder Executivo, dentro do próprio Poder Judiciário, dentro do próprio Ministério Público. Ainda há muita divergência quanto à implementação ou não dos direitos garantidos constitucionalmente e isso tem inviabilizado bastante a realização dessa política pública (...) Eu acho que o movimento social não se deu conta disso para poder reivindicar mais a implementação dessas políticas. (Entrevistado 9)
\end{abstract}

Já esclarecemos que não podemos fazer uma generalização sobre a percepção dos entrevistados e dos dirigentes a partir deste estudo, pois o caráter de uma pesquisa não aleatória nos priva dessa intenção. Indo além dos relatos expostos, dois dirigentes manifestaram algum otimismo na relação com a burocracia aqui estudada. Para esses dirigentes as Carreiras Típicas de Estado, objeto de nossa análise, têm relevância no processo de formulação e implementação de políticas públicas de uma forma geral, o que incluiria as políticas de promoção de igualdade racial, vejamos a percepção de um dirigente sobre essas carreiras:

Pessoas de alto nível. Alta qualidade de formação. Um extraordinário compromisso com o bem público. Eu por mim, chamava todos para trabalhar comigo pelo resto da minha vida (..) Em geral são pessoas que têm uma formação, vamos dizer assim intelectual (...) Altamente capazes para ajudar a 
formular políticas. Aonde eu estive sempre contei com uma contribuição inestimável dessas pessoas, desses técnicos. Inestimável, inclusive a própria ENAP nos convidava para debater a questão do racismo em cursos de formação de técnico. (Dirigente 2)

O Dirigente 4, quando tratou dos Advogados da União, descreveu uma relação profícua com os níveis superiores da AGU durante as negociações em que esteve como responsável por política de promoção da igualdade racial: “Advocacia Geral da União sempre deu um suporte bom para (...) a questão do 4887 (Decreto $\mathrm{n}^{\circ} 4.887$ de 20 de novembro de 2003 esclarecimento nosso) da questão quilombola, foi parceiro. A defesa de cotas, eu recebi uma entrega grande da Advocacia da União". Esse dirigente, entretanto, relata a dificuldade em atrair a carreira de Especialista em Políticas Públicas e Gestão Governamental para trabalhar com a questão racial: "Não é uma área que chame atenção de gestores, embora eu acho que ali para eles seria um campo bacana para se trabalhar". Quanto ao Ipea, todos os dirigentes mostraram que houve uma relação muito próxima e de solidariedade com o trabalho realizado. O Dirigente 4 pode resumir a opinião dos demais sobre a atuação dos Técnicos de Pesquisa e Planejamento do Ipea nas políticas de promoção da igualdade racial: "Ipea, muito bom...o Ipea sempre esteve conosco no fornecimento de dados, na análise da evolução das políticas de promoção da igualdade racial, produzindo inclusive livros e materiais específicos sobre esse tema, então o Ipea foi uma grata surpresa na administração pública".

O Dirigente 1 confirma a mesma percepção sobre o Ipea:

Tem sido seguramente o setor de maior valia para adensar as propostas do movimento negro. A gente tem se valido muito dos dados, dos estudos realizados pelo Ipea para poder provar que o que a gente sente na pele é verdade. Tem sido extremamente importante. Positivo. Extremamente positivo. (Dirigente 1)

As carreiras de gestão, os Especialistas em Políticas Públicas e os Analistas de Planejamento e Orçamento, parecem possuir um perfil mais próximo do fazer política agregando conhecimentos técnicos. Esse aspecto é muito evidenciado no desenvolvimento das políticas públicas. Os membros dessas carreiras quando foram questionados sobre a importância e o significado do cargo que exerciam, enfatizaram o problema de gestão no Estado. Vejamos o que diz o Entrevistado 11. 
Eu acho que era uma carreira muito importante para o Estado, para o Estado que a gente tinha. No início da Nova República. Eu acho que a concepção que a gente teve, ela é ainda importante para o Brasil porque nós não temos uma burocracia profissionalizada stricto sensu, nós temos várias carreiras criadas de maneira inorgânica e oportunista (...) Eu acho que ela foi concebida como uma carreira de gestão porque a gente achava que a gestão era o nosso ponto fraco. O ponto fraco do Estado eu continuo achando que é (a gestão, esclarecimento nosso) e continuo achando que vai ser por um tempo. (Entrevistado 11)

Descrevemos outras percepções, quanto a ter uma atuação política e de ser um ator político dentro do Estado e do Governo:

Justamente uma sequência de vida por escolhas políticas, escolhas de disputa social que eu faço desde muito novo, dentro da faculdade, cheguei a uma análise que para continuar essa disputa de sociedade eu teria que fazer um concurso público e dentro dos concursos públicos a carreira de EPPGG foi a que me apresentou a melhor possibilidade de intervenção e disputa de ideia, de concepções de sociedade. Então foi meio que a sequência direta de toda uma vida anterior. (Entrevistado 13)

Entrevistada 16:

Dentro do serviço público é uma posição muito importante do ponto de vista do executivo. Eu gosto da oportunidade de realizar projetos, de fazer as coisas (...) eu creio que é uma oportunidade muito interessante de fazer algo definitivamente pelo país. Eu realmente acredito nisso.

Entrevistado 20:

Eu tenho visto que a carreira tem um significado importante dentro do Poder Executivo, pelo menos, especialmente na definição de prioridades na questão orçamentária.

A Entrevistada 21 acompanha os seus colegas citados acima. Ela também se orgulha do papel desempenhado pela sua carreira na condução das políticas do Estado.

(...) e também tem um outro papel como analista que a gente tenta (...) a aproximação com a população. Para que ela possa ter mais informações sobre o que está sendo desenvolvido. O que está sendo executado pelo governo e possa com maior transparência ter mais voz. Tem, por exemplo, o Orçamento ao Alcance de Todos que busca traduzir o orçamento numa linguagem mais fácil para que as pessoas tenham maior familiaridade sobre o que está sendo alocado, onde está sendo alocado, e também que estamos buscando agora um maior envolvimento da sociedade organizada.

Ao ingressar na administração pública, os servidores membros das carreiras que participaram deste estudo interagem em um campo de luta pelo poder. A atuação desses servidores se dá como um meio de atender a diversos objetivos, ideais e até mesmo atender a objetivos egoístas como o poder pelo poder, como diria Weber (1971), para desfrutar exclusivamente o prestígio que o poder pode trazer. Os dirigentes das políticas de promoção 
da igualdade racial enxergavam na burocracia uma ponte técnica para o alcance dos objetivos a que essas políticas se propunham, beneficiar a população negra, para combater o racismo estruturante na sociedade brasileira.

\subsection{Influenciam e participam?}

"A burocratização da política e a politização da burocracia" 52 foi tratada empiricamente em um estudo realizado por Aberbach, Putnam e Rockman (1981) onde rompem com a dicotomia entre políticos e burocratas. Esses autores apontam as diversas faces do burocrata civil frente a questões do Estado. São investigados tanto políticos e burocratas quanto as suas atitudes, comportamentos e ideologias sobre o papel do Estado. O estudo de Aberbach, Putnam e Rockman (1981) traz uma ampla amostra de burocratas e políticos em países ocidentais, França, Alemanha, Itália, Holanda, Suécia, Inglaterra e Estados Unidos.

No Brasil, a relação entre políticos e burocratas na estrutura do Estado é espelhada nos cargos efetivos e de confiança. A estrutura administrativa do Poder Executivo Federal conta com pouco mais de 89 mil cargos, funções de confiança e gratificações. A ocupação desses cargos é de livre provimento e destituição pelo Presidente da República, ministros ou dirigentes máximos de órgãos governamentais. Os cargos de Direção e Assessoramento Superior (DAS, cargo de comissão ou cargo de confiança) ${ }^{53}$ são de fato cargos que ocupam o mais alto patamar do Poder Executivo Federal da Administração Direta quanto maior a categorização, mais alto o nível hierárquico. Os DAS totalizam mais de 22 mil $\operatorname{cargos}^{54}$.

52 Os autores afirmam que a mesma frase "a burocratização da política e a politização da burocracia foi usada para descrever as tendências do Estado na Alemanha (Nevil Johnson, Government in the Federal Republic of Germany: The executive at work; Mattei Dogan, The mandarins of Western Europe: The political role of top civil servant), na França ( Vicent Wright, Politics and administration under the french Fifth Republic ) e nos Estados Unidos (Hugh Heclo, A government of strangers: Executive politics in Washington).

\footnotetext{
${ }^{53}$ Os DAS se dividem em duas categorias: DAS 101 - Direção Superior e DAS 102 - Assessoramento Superior. Dentro dessas categorias há os seis níveis: DAS 101.1 (DAS-1); DAS 101.2 (DAS-2); DAS 101.3 (DAS-3); DAS 101.4(DAS-4); DAS 101.5(DAS-5); DAS 101.6(DAS-6); DAS 102.1(DAS-1); DAS 102.2(DAS-2); DAS 102.3(DAS-3); DAS 102.4(DAS-4); DAS 102.5(DAS-5); DAS 102.6(DAS-6). Entre parênteses, escrevem-se as denominações informais.

${ }^{54}$ Fonte: Boletim Estatístico de Pessoal/MP - vol. 17, nº 200, Dez/2012
} 
Por meio dos DAS‘s, o Estado tem o seu corpo dirigente à frente de postos de comando, recrutando pessoas do serviço público e do setor privado para exercer funções gerenciais. A literatura considera cargos de mando os DAS-5, DAS-6 e o de Natureza Especial (BONIS; PACHECO, 2010; D’ARAÚJO; LAMEIRÃO, 2009, 2011). Não se inclui o cargo de Ministro de Estado, pois é um cargo essencialmente político. Por outro lado, os DAS 1 a 4 têm decisões muito limitadas pela linha hierárquica, apesar de gerenciarem grupos de pessoas. É pouco comum essa distinção nos DAS 1 a 4 localizados nos Estados da Federação, ou seja, fora de Brasília, onde acontece de um DAS 3, por exemplo, ter responsabilidades e atribuições informais equivalentes a um DAS 5 ou, no mínimo, DAS 4 em Brasília.

O fato de haver uma alta concentração de DAS nos níveis 1, 2 e 3 vis-à-vis os DAS nos níveis 4, 5 e $6^{55}$ leva Costa (1993) a entender que existe um uso diferente para cada um deles. O autor considera que os níveis menores de DAS, 1, 2 e 3, são utilizados como mecanismos informais de promoção profissional e incentivo financeiro oferecidos a servidores do próprio órgão ou para atrair servidores com melhor qualificação de outros órgãos da administração pública. Isto é visto por Costa (1993) como uma medida compensadora para a falta de uma política de recursos humanos na administração pública. Como há um salto salarial a partir do DAS 4, o autor acredita que há aí uma reserva de mercado para trazer pessoal qualificado de fora de Brasília; pela falta de dados confiáveis o autor evita especular o uso clientelista dos DAS quer seja de nível inferior (1 a 3), médio (4) ou superior (5 e 6).

Na mesma linha de discussão de Costa (1993), D’Araújo e Lameirão (2011) problematizam o teor do Decreto $n^{\circ} 5.497 / 2005$ que estabelece um percentual mínimo de ocupação dos DAS 1 a 4 por servidores de carreira, sendo $75 \%$ nos DAS 1,2 e 3; e $50 \%$ nos DAS 4 . O decreto não menciona a ocupação de servidores nos DAS 5 e 6 e nos cargos de Natureza Especial. D’Araújo e Lameirão (2011) elucidam que o governo, em 2007, não obedecia os próprios limites instituídos por meio do decreto, possuindo entre seus quadros de DAS um percentual de "não servidores" acima do permitido. Contudo, argumentam as autoras, em 2010, os DAS dos níveis 1 a 3 permaneciam com percentual de ocupação de servidores

\footnotetext{
${ }^{55} \mathrm{Na}$ época em que conduziu o estudo Costa (1993) encontrou 90,2\% de DAS nos níveis 1,2 e 3; e 9,8\% nos níveis 4, 5 e 6. Atualmente, conforme o Boletim Estatístico de Pessoal/MP - vol. 17, n 200, Dez/2012, os DAS 1, 2 e 3 são 80,6\% e os DAS 4, 5 e 6 constituem 19,4\% do total de DAS do Poder Executivo da Administração Direta e Indireta.
} 
efetivos abaixo dos limites instituídos, 75\%; e os cargos de DAS 4, por outro lado, chegavam a 64,6\%, acima do limite regulamentado de 50\% (D’ARAÚJO; LAMEIRÃO, 2011:102).

Essas autoras ainda afirmam que, no período de 1996 a 2010, os DASs níveis 1 a 4 tiveram uma relativa estabilidade, somente em 2003 e 2006 é que houve um aumento sútil. Os DASs 5 e 6 tiveram um aumento expressivo durante o governo Lula no período estudado pelas autoras de 2003-2010 (D’ARAÚJO; LAMEIRÃO, 2011:104).

Levando em consideração o modelo brasileiro de articulação entre política e administração pública, talvez só aqueles servidores públicos que ocupam DAS tenham alguma voz no processo de tomada de decisão. Costa (1993), ao buscar um modelo de gestão pública, nos relata sistemas políticos-administrativos internacionais e constata que há uma grande variedade de modelos, nenhum estático ou puro. $\mathrm{O}$ autor ressalta o modelo britânico onde o High Civil Service são equivalentes aos nossos DAS e lá eles não estão livres de sofrerem críticas pela inflexibilidade gerencial. A burocracia britânica constitui uma elite administrativa, intelectual e social, mas nem por isso se confunde com a elite política, pelo contrário, há uma ampla separação entre as funções administrativas e as representativas. Costa (1993) provoca ao destacar que existe uma grande distância entre o caso brasileiro e o britânico:

\footnotetext{
A Secretaria do Gabinete (no sistema brasileiro é equivalente à Casa Civil sem o braço político, explicação nossa), criada em 1916, teve apenas seis diretores, e um dos últimos Secretários do Gabinete, Sir Robert Armstrong, obviamente um funcionário de carreira exemplar, assumiu esse cargo em 1979, 'coroando uma carreira que se desenvolveu tanto sob a administrações trabalhistas como conservadoras” (COSTA, 1993:259).
}

Costa (1993) prossegue nos relatando que os Estados Unidos possuem um modelo híbrido, cujo sistema de nomeação para os altos escalões é compartilhado com o Congresso Nacional. A carreira de Senior Executive Service é composta por pessoas que se situam abaixo dos nomeados políticos do Presidente da República, ou seja, numa equivalência seriam os DAS 6 e 5 do sistema brasileiro. Essa carreira é o link entre os "Ministros" e o restante da força de trabalho dos órgãos governamentais. Lewis (2008) denuncia que há uma quantidade enorme de cargos em comissão de livre nomeação do Presidente da República, cerca de 3000. Compara a relação com a França, Inglaterra e Alemanha que varia de 100 a 200 nomeações. O autor acredita que o Presidente, por meio da nomeação dos cargos em 
comissão de alto escalão, procura controlar a burocracia e a indicação política originária do parlamento.

No modelo francês, formado por uma elite de funcionários generalistas - Corps des Administrateurs Civils, a burocracia possui uma alta integração socioeconômica com a elite política e ao mesmo tempo preserva uma autonomia diante do assédio das estruturas políticos-partidárias e dos grupos de interesse conforme discorre Costa (1993). O que agrada ao autor é muito menos a formação dada pela École Nationale d'Administration (ENA) que considera superficial, mas o desempenho da burocracia francesa que é voltada para resultados; o processo de seleção rigoroso e ao mesmo tempo flexível para a formação de um quadro administrativo relativamente jovem e dinâmico.

Estudiosos sobre a burocracia e os cargos de confiança no Brasil definem os ocupantes de alto escalão como policy makers, são eles que têm a responsabilidade pela tomada de decisão política (BONIS; PACHECO, 2010; D’ARAÚJO; LAMEIRÃO, 2011; LOUREIRO; ABRUCIO, 1999). D'Araújo e Lameirão (2011) argumentam que o policy maker é um modelo híbrido de atuação que conjuga característica dos políticos e dos burocratas. Loureiro e Abrucio (1999) entendem que os ocupantes de cargos no alto escalão, legitimados pelo processo democrático, decidem pelas saídas técnicas existentes. Num ambiente republicano e democrático, Loureiro, Olivieri e Martes (2010b) entendem que o burocrata só exerce o papel de direção no Estado se tiver o respaldo estratégico de algum ator político que possa sustentar a sua posição. Assim, esse poder dificilmente será exercido apenas com o uso de seus recursos próprios, o conhecimento técnico.

Destoante da nota cantada pelos autores acima, Weber (1993) defende que o poder dos burocratas reside no saber e na divisão administrativa do trabalho, um saber construído nas instituições de ensino e nas práticas administrativas cotidianas. $\mathrm{O}$ primeiro campo traz o conhecimento técnico especializado; já o espaço de poder da burocracia dá origem às informações em razão do exercício do cargo: "somente quem tiver acesso a essas informações, sem depender da boa vontade de um funcionário qualquer, conseguirá controlar eficazmente a administração" (WEBER, 1993:73). 
A experiência internacional corrobora o papel do burocrata no aparelho do Estado sob a perspectiva weberiana. Kingdon ${ }^{56}$ (1995) analisou empiricamente a influência das carreiras burocráticas civis na administração pública dos Estados Unidos. Ele tomou a percepção de alguns atores que atribuem uma baixa proeminência da burocracia na definição da agenda a ser implementada no Estado. Entretanto, na fase de implementação a burocracia se mostrou altamente presente e também nas propostas de alternativas às agendas que foram definidas politicamente. Kingdon (1995), com base na percepção de seus entrevistados, enumera os recursos que a burocracia possui para marcar a sua influência e o seu papel nas relações administrativas e políticas dentro do Estado: i) perenidade - o autor argumenta que dessa forma os servidores podem capturar os nomeados politicamente sem vínculo com o Estado, pois são eles que estão em um órgão governamental há muito tempo e conhecem a máquina na sua profundidade; ii) expertise - o conhecimento técnico e a larga experiência em administrar as ações governamentais levam os burocratas a tratar com grupos de interesse e parlamentares o que os habilitam a trabalhar no processo de planejamento e nas mudanças das políticas governamentais; iii) relacionamentos - a rede profissional com pessoas no Parlamento e com grupos de interesse, cunhada pelo autor de triângulo de ferro, pois envolve os interesses de três grupos: burocratas, parlamentares e grupos de interesse. Triângulo de ferro porque se encaixam perfeitamente e muitas vezes são impenetráveis por pessoas externas e incontroláveis pelo Presidente da República, Dirigentes Políticos e até mesmo por parlamentares que não fazem parte da área em questão.

A partir de análises empíricas sobre o cotidiano da administração pública, Oliveira, N.V. (2009) revela que é imperativo para um político que a máquina estatal funcione conforme as suas decisões e vontades. Isso não quer dizer que o político seja mal intencionado, pois os seus projetos de interesse podem coincidir com os projetos da administração pública. Esse mesmo autor, afirma que a autonomia do funcionário é maior entre aqueles que são efetivos do que entre os servidores públicos sem vínculo com a administração pública e nomeados para o exercício de algum cargo temporariamente, ou seja, a inserção lateral de outsiders, profissionais que não são enquadrados como servidores efetivos (BONIS; PACHECO,

\footnotetext{
${ }^{56} \mathrm{O}$ autor realizou 247 entrevistas com pessoas envolvidas na área de saúde e transporte ao longo de 1976-1979. As pessoas entrevistadas eram do quadro de funcionários do Congresso Nacional, comitês ou órgão governamental; equipe do Presidente da República e dirigentes políticos da área da saúde e do transporte; servidores efetivos dessas áreas; grupos de interesse; jornalistas; pesquisadores, acadêmicos e consultores.
} 
2010). Adotamos essa hipótese e acreditamos que a autonomia defendida por Weber depende da própria condição do burocrata e deve ser relativizada.

Trabalhos de Abrucio, Pedroti e Pó (2010), Gouvêa (1994), Nunes (2003) e Schneider (1994) nos dão um panorama da história política e da administração pública brasileira, eles demonstram que a autonomia da burocracia se dava com o patrocínio de alguma autoridade superior. $\mathrm{O}$ insulamento burocrático, a tecnocracia e a burocracia paralela foram fenômenos utilizados por determinados governos para fazer avançar projetos de desenvolvimento no país. Incluem-se nesse rol, o governo de Getúlio Vargas, o Governo de Juscelino Kubitschek e o período em que o regime autoritário governou o país. Esses governos foram marcados pela alta independência de alguns setores da burocracia estatal e pelo isolamento das pressões político-partidárias. A política pública era exercida pela burocracia e isso se exacerbou com o fechamento do Congresso Nacional no regime militar e com a repressão aos movimentos sociais. Em um sistema democrático dificilmente existiria uma burocracia que acumulasse poderes políticos e técnicos. Há um protagonismo do parlamento, ou seja, da representação política que vem do cidadão e um protagonismo dos movimentos sociais.

Todos os dirigentes entrevistados para esta pesquisa imputaram às carreiras deste estudo um poder de decisão que é muito discutível: "fazem acontecer ou não deixam acontecer" (Dirigente 4). Ao mesmo tempo os membros dessas carreiras não se percebiam como agentes essenciais do processo de decisão. No máximo a participação se resumia em repassar dados e informações para quem de fato tomava a decisão ou participava dela na perspectiva desses servidores. Há uma diferença, por outro lado, entre aqueles que exercem cargos em comissão, assim como há diferença substancial conforme a carreira dos respondentes como podemos analisar nas Tabela 16 e Tabela 17. 
Tabela 16 - Percentual de servidores no exercício de DAS e participação em processos decisórios de políticas públicas

\begin{tabular}{cccc}
\hline \multirow{2}{*}{ Exerce DAS } & \multicolumn{2}{c}{ Participa de processos decisórios } & Total \\
& Não & Sim & \\
Sim & & & 36,5 \\
& 25,7 & 52,8 & \\
Não & & & 63,5 \\
\multirow{2}{*}{ Total } & 74,3 & 47,2 & 100 \\
\hline Fonte: Dados primários - Elaboração da própria autora, 2014 & 100 &
\end{tabular}

Perguntamos para os respondentes se participavam de decisões de formulação e implementação de políticas públicas. Durante a realização desta pesquisa, $74 \%$ daqueles servidores que não exerciam DAS disseram que não participavam dos processos de decisão, contra $25,7 \%$ dos que exerciam cargo em comissão. Por outro lado, entre aqueles que exerciam DAS, cerca de $53 \%$ afirmaram participar de decisões de políticas públicas. Entretanto, podemos observar também que a maioria dos servidores estão no grupo que não exerce DAS e não participa de processos decisórios, 63,5\% pela percepção dos próprios servidores que responderam ao questionário.

Observamos que entre os nossos respondentes há uma grande possibilidade de alguém exercer DAS e participar de tomadas de decisão sobre a formulação e a implementação de políticas públicas. Como destaca D’Araújo e Lameirão (2011) não existe cargo de direção sem a possibilidade de tomar decisões, fazer escolhas autônomas e, acrescentaríamos, de participar do processo decisório. Na Tabela 18, notamos que 55\% dos que consideram que participam de decisões sobre formulação e implementação de políticas públicas ocuparam cargos em comissão no período de 2007 a 2012. Desses, 23\% ocuparam cargos de DAS 4 para cima. O que significa uma alta possibilidade de ter participado de processos de decisão naquele período. Se determinada pessoa ocupa cargo em comissão na administração pública, em algum momento ela tomou decisões sobre os rumos da política pública no Brasil e se esse cargo for de DAS 4 para cima as possibilidades são quase certas. 
Tabela 17 - Percentual de servidores no exercício de DAS (2007-2012) e participação em processos decisórios de políticas públicas

\begin{tabular}{|c|c|c|c|c|}
\hline \multirow{2}{*}{ Participa de decisões } & \multicolumn{3}{|c|}{ NivelDAS(2007-2012) } & \multirow{2}{*}{ Total } \\
\hline & Não DAS & $<=$ DAS-3 & $>=$ DAS-4 & \\
\hline Não & 55,2 & 30,4 & 14,4 & 100 \\
\hline Sim & 29,9 & 34,9 & 35,2 & 100 \\
\hline tal & 45,1 & 32,2 & 22,7 & 100 \\
\hline
\end{tabular}

Fonte: Dados primários - Elaboração da própria autora, 2014

Costa (1993) defende que existe um relacionamento entre as duas variáveis, participação nos processos decisórios e ocupação de DAS. Para testar essa hipótese, fizemos o teste quiquadrado de Person $^{57}$ trabalhando com os respondentes que no momento do preenchimento do questionário exerciam DAS.

Os resultados demonstram que há uma associação significativa entre o exercício de DAS e a participação em processos de decisão, $\chi^{2}(1)=64,66(p<0,001)^{58}$, isso representa que aqueles que ocupam DAS têm três vezes mais chances de participar da tomada de decisão do que aqueles que não exercem DAS. Quando consideramos o exercício de DAS entre 2007 e 2012 e se participam de decisões de políticas públicas os resultados são semelhantes, $\chi^{2}$ (1) $=74,24(\mathrm{p}<0,001)$, com uma chance de quatro vezes daqueles que têm DAS de participar da tomada de decisão em relação aqueles que não exercem DAS.

Pelos dados descritivos, percebemos que a carreira do servidor também influencia na participação do processo decisório. Vejamos a Tabela 18, 58\% dos Especialistas em Políticas Públicas e Gestão Governamental afirmaram participar do processo decisório, seguidos pelos Analistas de Planejamento e Orçamento, 48\%, mais um dado que reforça a nossa convicção de que essas duas carreiras se aproximam do perfil técnico-político.

\footnotetext{
${ }^{57}$ Equação do qui-quadrado: $\chi^{2}=\sum \frac{\left(\text { Observado }^{\mathrm{ij}}-\text { Modelo }^{\mathrm{ij}}\right)^{2}}{\text { Modelo }^{\mathrm{ij}}}$

${ }^{58}$ Foram 180 respondentes que têm DAS e participam de processos decisórios de políticas públicas; 132 possuem DAS e não participam de decisões; 161 não tinham DAS e participavam de decisões de políticas públicas e 381 não tinham DAS e não participavam de processos decisórios.
} 
Tabela 18 - Percentual das carreiras na participação de processos decisórios de políticas públicas

\begin{tabular}{ccccccc}
$\begin{array}{l}\text { Participa } \\
\text { de } \\
\text { processos } \\
\text { decisórios }\end{array}$ & Adv.União & APO & EPPGG & $\begin{array}{c}\text { Proc. } \\
\text { Federal }\end{array}$ & TPP- Ipea & Total \\
Não & 75,4 & 52 & 41,7 & 71,2 & 31,6 & 60,1 \\
& & & & & & \\
Sim & 24,6 & 48 & 58,3 & 28,8 & 68,4 & 39,9 \\
& 100 & 100 & 100 & 100 & 100 & 100 \\
\hline
\end{tabular}

A declaração da carreira do Ipea chama a nossa atenção, 68\% afirmaram que participam da tomada de decisão na administração pública. Vimos que há uma grande difusão dos trabalhos do Ipea tanto pela mídia como na fundamentação de decisões tomadas nos gabinetes da administração pública. Uma carreira que tem como perfil a liberdade ideológica e de opinião como constatou D'araújo, Farias e Hippolito (2005) ao mapear os 40 anos do Ipea por meio da trajetória de seus dirigentes e técnicos que se tornaram referência daquele Instituto. Logo, é esperado que haja uma autopercepção valorativa dos estudos realizados pelos TPPs como identificamos na fala do Entrevistado 6.

Às vezes participo diretamente, às vezes não. Quando você faz análise crítica você ajuda a melhorar a política e como a gente está muito aqui, quando você começa falar muito de determinadas áreas, você é chamado para dar depoimentos no Congresso, na Câmara (dos Deputados, esclarecimento nosso), no Senado, conversa com Senador e Deputados (...) indiretamente você contribui de alguma forma, pelo menos para o debate (...). Porque você só participa diretamente se você tem afinidade com as pessoas que estão tomando decisão, se você não tem afinidade com as pessoas que estão tomando decisão, aí você só pode participar indiretamente. (Entrevistado 6)

Um outro depoimento, da Entrevistada 7, nos leva a entender a percepção dos TPPs sobre a construção da imagem do Ipea e da sua carreira.

O Ipea tem uma tradição que pesa. Qualquer um que vai entrar no Ipea sabe o tipo de mochila que ele já vai carregar nas costas porque é uma instituição que pesa no melhor sentido. É uma instituição tradicional de elite, elite em termos de formação acadêmica das pessoas que constituem o corpo de funcionários, elite em termos do salário (...) Você dizer que você é funcionário do Ipea, significa uma coisa. Agora além de ser uma pessoa que fiz duas carreiras universitárias, dois mestrados, um doutorado. Tenho 20 anos de experiência fora do Brasil, internacional. Falo seis idiomas (...) além do currículo eu digo que sou funcionária do Ipea, pega muito bem, digamos assim. (Entrevistada 7) 
O movimento social negro relata as parcerias realizadas com o Ipea. O Instituto surge como um ator estatal importante para validar as denúncias há muito tempo feitas pelo movimento social negro.

\begin{abstract}
O governo, como tinha uma conferência da ONU, tinha que produzir dados e informações informações essas que sempre estiveram disponíveis. O Ipea descobriu a existência da desigualdade racial no Brasil com dados desde a década de 1940. Quer dizer: os dados estavam aí. Mas o Ipea, que eu saiba tinha muito pouco trabalho em relação a essa questão. A Conferência pautou o Ipea e ele então teve que analisar os dados que estavam disponíveis, produzidos pelo IBGE. Montou um megaprojeto, em que inicialmente, pelo que dizia o Ricardo Paes de Barros ${ }^{59}$, eles tinham a intenção de analisar cerca de quinhentas variáveis para fazer um diagnóstico completo das desigualdades raciais no Brasil. Não fizeram tudo isso, mas trabalharam alguns dados importantes acerca da educação, de renda, emprego, essas coisas. E o Ipea então passou a falar, com a legitimidade de ser o principal órgão formulador de políticas públicas no Brasil, de desigualdade racial. E passou a dizer: "A pobreza é negra." Apresentou o famoso gráfico das paralelas que jamais se encontram, que mostrava que a diferença de escolaridade média de negros e brancos era a mesma em três gerações. O presidente do Ipea, Roberto Martins ${ }^{60}$ se envolveu pessoalmente, além do Ricardo Henriques ${ }^{61}$. Você tinha, então, um órgão de governo dando legitimidade ao discurso que o movimento negro vinha fazendo havia décadas (Entrevista de Edna Roland ao CPDOC - ALBERTI; PEREIRA, 2007:379-380)
\end{abstract}

As carreiras jurídicas têm um percentual bem menor de participação, menos de $40 \%$ declararam que participam do processo de decisão, sendo 12\%, Advogados da União e 27\%, Procuradores Federais. Essa avaliação contradiz com a percepção dos dirigentes que foram entrevistados para essa pesquisa. O trabalho das carreiras jurídicas consiste em opinar sobre a legalidade de um ato de forma consultiva. Após a análise jurídica, o dirigente público tem a liberdade de acatar ou não o parecer jurídico. A autoridade superior do órgão governamental provavelmente não irá tomar uma decisão sem um respaldo da sua área jurídica. Pode ocorrer? Pode, mas a possibilidade dessa decisão saltar aos olhos dos órgãos de controle e judiciais é grande, sobretudo porque, como afirma Farah (2011), ainda vivemos sob o peso do legado da tradição "law oriented" na administração pública brasileira (FARAH, 2011:823). Igualmente, como ressaltou o então Advogado-Geral da União, Luis

\footnotetext{
${ }^{59}$ Ricardo Paes de Barros, doutor e pós-doutor em economia pela Universidade de Chicago (1988) e pós-doutor em economia pela Universidade de Yale (1989), ambos nos Estados Unidos, é pesquisador do Ipea desde 1979 (ALBERTI; PEREIRA, 2007:379).

${ }^{60}$ Roberto Borges Martins foi presidente do Ipea de 1999 a 2003. Doutor pela Universidade Vanderbilt, nos Estados Unidos, com a tese "Crescendo em silêncio: a economia da escravidão no século XIX em Minas Gerais", é professor aposentado do Departamento de Economia da Universidade Federal de Minas Gerais (UFMG) (ALBERTI; PEREIRA, 2007:379).

${ }^{61}$ Ricardo Henriques, economista, foi pesquisador do Ipea, onde, cerca de um mês antes da III Conferência Mundial de Combate ao Racismo, publicou o artigo "Desigualdade racial no Brasil: evolução das condições de vida na década de 90" (Rio de Janeiro, Ipea, julho de 2001). Foi titular da Secretaria de Educação Continuada, Alfabetização e Diversidade (Secad/MEC) durante o primeiro governo Lula (2003-2006) (ALBERTI; PEREIRA, 2007:380).
} 
Inácio Lucena Adams, a opinião do jurídico é carregada de legitimidade técnica e moral (VAZ, 2010), então, por menor que seja o exercício das carreiras jurídicas em cargo de comissão e a sua baixa percepção do processo em si de decisão, há uma participação quase que intrínseca das carreiras jurídicas no fluxo decisório, pois a opinião desse grupo de servidores sempre é consultada para a formulação ou implementação de políticas públicas.

O exercício de cargo comissionado é uma condição exclusiva para funções de direção, no limite, oportuniza a participação nos núcleos estratégicos de decisão (CÂMARA, 2009).Voltando à controvérsia sobre os processos decisórios onde as interações humanas levam ao compartilhamento de responsabilidades que se dão no ambiente organizacional como debate Harmon (1995), ao ser questionado se os impasses na administração pública não seriam de solução política e menos de responsabilidade técnica, o Dirigente 1 nos deu a seguinte reflexão:

\begin{abstract}
A compreensão política com relação a essas questões, isso é um embate. Nós vivemos hoje um embate, nós não temos hoje uma maioria no Congresso capaz de fazer isso. Eu diria que até nos últimos anos retrocedemos. Hoje o Congresso é mais conservador do que era há oito anos atrás. Há um avanço nos setores conservadores no sentido de endurecer e ampliar essas dificuldades. E eu já falei de uma delas com relação a questão indígena no qual o Congresso quer avocar para si a condição de definidor das políticas públicas de reconhecimento de terras indígenas, assim como de reconhecimento das terras quilombolas (...) Agora eu não posso deixar de reconhecer e evidenciar de que no campo jurídico há, independente de decisões que sejam adotadas no campo político e no campo executivo, há no campo jurídico um caldo de cultura extremamente elitista, conservador e reacionário. E que é exercido com muita sofreguidão por qualquer operador que se disponha a operá-lo. Corpo jurídico, a legislação...como eu diria...o arcabouço legal brasileiro dá um poder de tal ordem ao corpo jurídico que possibilita e permite o exercício individual do bloqueio. $\mathrm{O}$ exercício individual da discriminação com um lastro legal gigantesco. Mesmo quando você tem uma decisão política proativa (...) Esse exercício então se é verdade de um lado que precisa de decisão política e é dela que advirá o avanço, por outro lado também é necessário se criar alguns mecanismos já imediatos para pelo menos conter a sanha conservadora que emergiu por conta da implementação das políticas de ações afirmativas.
\end{abstract}

A questão que se coloca é se a burocracia técnica que não gestou um programa de governo, não foi eleita para governar, será que, na sua prática cotidiana da máquina estatal, respeita e conduz o programa de governo eleito? Ou seja, seriam fiéis a uma moral superior conforme descreve Weber ao analisar o governo e o parlamento alemão. Não há no ponto de vista weberiano um impasse entre a política e a burocracia:

Um funcionário que receba uma ordem que considere errada pode, e deve, expor seu ponto de vista. Se a instância superior insistir na ordem, é não somente sua obrigação mas até ponto de honra executála como se ela correspondesse a sua própria convicção e, assim, mostrar que o seu senso de obrigação 
está acima de suas convicções pessoais. (...) O funcionário deve permanecer acima dos partidos, na verdade, porém isso quer dizer, fora da luta por poder próprio (WEBER, 1993:55-56).

Oliveira, N.V. (2009), baseado em suas análises empíricas, não entende que haja uma burocracia fechada em si. O que esse autor defende é que os burocratas técnicos - os servidores, exercem um comportamento quase que servil em relação aos seus superiores: "Suas ideias são ouvidas, não questionadas. Suas ordens, cumpridas. Ainda quando ocorre de haver discordâncias, estas jamais foram apresentadas como obstáculos reais às vontades dos dirigentes" (OLIVEIRA, N.V., 2009:56). Mas, será que seria um jogo de aparências?

\begin{abstract}
Existe um conservadorismo, um aparato técnico do Estado brasileiro com certeza que há, e mesmo os chefes da pasta às vezes não conseguem dar conta daquela agilidade, eu conversava com o ministro Fernando Haddad na época, nós conversamos, reunimos para poder discutir a tradução da História da África, dos oito volumes da História da África que a Unesco tinha preparado. Na quinta reunião ou sexta que nós perguntamos quando ficaria pronto o material...o Haddad disse assim...a gente conversando...os técnicos...disse assim... 'mas ...de novo... não acaba...puxa vida...' é porque a decisão dele já estava tomada, de botar os recursos, mas porque, primeiro era um volume extenso de trabalho...segundo, aquilo ia devagar...e os técnicos nunca dizem não para o superior....ele não é bobo...pelo contrário...(...) mas a maioria não diz não...e aí ....aquilo não anda...aquilo fica preso...e aquilo não acontece. Eu percebo que isso é o desenho da máquina burocrática que é conservador e que a gente tem que trabalhar com muita atenção e com muita capacidade para sensibilização. (Dirigente 3)
\end{abstract}

Por outro lado, Godoy e Teixeira (2009) constatam que nas áreas onde há uma hierarquização e uma menor politização - no sentido de haver um maior número de indicações políticas no preenchimento de cargos em comissão que não feitas por servidores efetivos e do próprio órgão - é mais "difícil manobrar a burocracia". Isso significa, na interpretação desses autores, que as políticas de longo prazo são mais factíveis e os burocratas têm um maior poder frente aos políticos. Diferentemente dos espaços onde a politização é mais forte, posto que a simples ameaça de substituição dos burocratas já garante o apoio ao programa de governo.

Mas, não podemos diminuir a influência dos burocratas no processo de decisão. Essa influência é reconhecida pelos dirigentes de políticas de promoção da igualdade racial que participaram deste trabalho. Eles não ignoram o caráter político da atuação desses servidores. Loureiro, Olivieri e Martes (2010b) nos fazem refletir sobre a relação entre o político e o burocrata no espaço institucional. 
(...) afirmar a relevância dos burocratas nas decisões governamentais não significa ignorar sua dependência institucional em relação à autoridade política, nem tampouco negar que a responsabilidade última pelas decisões é dos políticos (...). Por outro lado, afirmar a dependência institucional do poder dos burocratas em relação aos políticos não significa reduzir a burocracia a mero instrumento do Poder Executivo (ou do gabinete, em sistemas parlamentaristas). (LOUREIRO; OLIVIERI; MARTES, 2010b:75)

Vejamos no caso do Ipea, onde à primeira vista parece haver uma certa institucionalização ou habitus sensível às discussões construídas pelo movimento social negro. Mas não é uma institucionalização, como podemos inferir pela fala do ex-Presidente do Ipea, Roberto Borges Martins. Não é o Estado, materializado no Ipea, que está preocupado com a questão racial, mas o indivíduo. Talvez a sua trajetória de vida o leve a tomar decisões prós ou contrárias às bandeiras de luta do movimento social negro para a população negra.

\begin{abstract}
(...) Implantei, com o apoio pessoal do presidente Fernando Henrique, uma forte linha de pesquisa sobre desigualdades raciais. O Ipea nunca tinha mexido com isso, o IBGE pouca atenção dava, por isso começamos a produzir e divulgar estatísticas sobre desigualdades raciais: desigualdades educacionais, de renda, de emprego, de condições de vida. Isso começou em 2001, quando a ONU convocou a Conferência de Durban, na África do Sul, a conferência mundial contra o racismo. O Ipea foi convidado a entrar no comitê organizador da delegação brasileira e participou intensamente da preparação das posições do Brasil; fomos uma espécie de braço técnico da delegação. Antes, durante e depois de Durban, o Ipea deu uma grande contribuição sobre esse tema. Após a conferência, continuamos a produzir e divulgar dados sobre desigualdades raciais, mostrando que elas não estavam diminuindo, e mesmo depois que saí ficou um grupo muito bom na casa trabalhando com essa questão. Tenho muito orgulho, porque isso se tornou uma referência para o movimento negro, a grande mídia e a própria sociedade brasileira, sempre tão pronta a ignorar a questão racial. Pessoalmente, devo ter percorrido uns vinte estados brasileiros fazendo debates e palestras sobre desigualdade racial. Fui também à Genebra, ao Equador. Além de mim, outras pessoas do Ipea também falaram muito sobre o assunto. Falávamos no Congresso Nacional, em assembleias legislativas, na televisão, em universidades, em outros órgãos do Executivo e de outros poderes, participamos de debates sobre a adoção de cotas raciais na UnB e também na UFRJ, na UFMG, e em São Paulo, na Escola Paulista de Medicina (...) O Ipea media e estudava a pobreza com um nível impressionante de precisão: sabia a cor do olho do pobre, a estatura, o estado civil, o lugar onde morava, o que fazia. O que fizemos foi introduzir o quesito racial nos trabalhos sobre pobreza e desigualdade que a casa sempre fez. Para mim, foi a atividade mais marcante da minha gestão. (Entrevista de Roberto Borges Martins ao CPDOC - D’Araújo, Farias e Hippolito, 2005:383-384)
\end{abstract}

O depoimento do ex-Presidente do Ipea nos dá uma dimensão do que é trabalhar com a questão racial no Estado, sobretudo, em um processo que na época ainda estava em construção e que requeria a sensibilização de pessoas que eram chave na sua condução.

Vejamos a fala de uma colaboradora do ex-Presidente do Ipea, Roberto Borges Martins.

Nós nos demos conta quando fomos analisar os dados que não tínhamos o dado racial no serviço público. E pensamos, uê, como assim? E fomos ver que não tinha o quesito no SIAFI [Sistemas Integrados de Acompanhamento Financeiro]. Então tem que pôr o quesito... o que a gente achava que era a coisa mais simples do mundo, só acrescentar o quesito raça/cor, utilizando a categoria do IBGE, se transformou numa guerra. E o Roberto [Martins, então Presidente do Ipea] foi um lutador 
incansável. Nós fomos à Secretaria de Recursos Humanos [da Administração Federal] e fizemos uma reunião para pedir a inclusão do quesito. Foi uma quantidade enorme de reuniões. [Os argumentos eram] que não podia, que já tinham tentado, que não tinha dado certo, que era inconstitucional... e o Roberto fez várias apresentações, com um kit com informações, bem impactantes. E fizemos uma reunião com um monte de gestores e tinha um negro, o único negro, e todo mundo tava meio calado, e ele disse que não queria, que estava ali por mérito e não pela cor dele. E o Roberto dizia: mas, eu não entendo vocês, a cota existiu sempre só que era para os brancos. [...] todos [brancos e negros] fazem parte de uma corrida só que as condições são muito diferentes. Fizemos então um monte de reuniões, com vídeo conferências com todos os responsáveis de recursos humanos nos estados. E foi uma coisa inacreditável, e não pensei que isso fosse acontecer. [...] e até hoje deve estar lá, só que ninguém preenche... e fizemos também uma campanha do governo, de dois e três meses, em que teoricamente todas as áreas de recursos humanos estimulassem os seus funcionários a preencher e nós também colocamos um item, não quero responder, para que as pessoas se sentissem bem à vontade e acabou que não foi bem feito (Entrevista de Nathalie Beghin ${ }^{62}$ para PAULA, 2010:93-94)

Esses relatos somente ilustram os obstáculos impostos pela estrutura do Estado para fazer avançar uma ideia. Se a burocracia para dirigir ou participar do processo decisório está vinculada à decisão de atores políticos, mesmo assim, acreditamos que o espaço político decisório não é isento de sua influência. Os burocratas são atores-chave no processo de formulação e implementação de políticas públicas, haja vista, o poder que detêm do conhecimento burocrático e técnico. Eles garantem a sua autonomia quando se valem do vínculo funcional que possuem, da área em que atuam, da estrutura da máquina pública e do apoio da sociedade quanto a sua importância e legitimidade no Estado moderno.

\footnotetext{
${ }^{62}$ Nathalie Beghin é economista pela Universidade Livre de Bruxelas (ULB) e Doutora em Políticas Sociais pela UnB. Foi pesquisadora do Ipea (1992-2006), Assessora do Representante do Banco Interamericano de Desenvolvimento (BID) no Brasil (2006/2007) e Advocacy Adviser da Oxfam Internacional no Brasil (20072009). Por ocasião da pesquisa exercia o cargo de Coordenadora Interina do Escritório de Oxfam Internacional no Brasil. A entrevista foi concedida para Marilene de Paula na sede da Oxfam, em Brasília, em 24/02/2010 (PAULA, 2010:149).
} 


\subsection{0 processo de decisão das políticas públicas e o papel da burocracia}

Os burocratas constituem atores do processo de decisão política cujas ações são interrelacionadas durante toda a fase de formulação e de implementação das políticas públicas. Relacionam-se, também, em todas as fases com outros atores públicos e privados. O seu papel, portanto, pode ser a tomada de decisões ou a orientação estratégica para a tomada de decisão.

Operacionalmente, Lindblom (1980) analisa o processo de decisão política e de formulação da políticas públicas nos Estados Unidos. Lindblom (1980) defende que uma das funções dos servidores, ou burocratas, é subsidiar o processo de decisão por meio de análises técnicas; reconhece que os burocratas desempenham papel importante no processo de decisão política. O autor afirma que no senso popular se acredita que os governos precisam se valer mais da pesquisa e das análises para solução de problemas relacionados com as políticas governamentais. Entretanto, apesar de as pessoas acreditarem nesse princípio, desejam que a decisão política se mantenha sempre como um processo político, ou seja, as autoridades devem usar os serviços de analistas e técnicos sem abdicarem de suas funções políticas. Assim, o autor afirma que, de um lado, as pessoas querem que a política pública se baseie em ampla informação e seja bem analisada. De outro, preferem que o processo decisório seja democrático - político. Portanto, um processo de política pública mais científico sem deixar de ser político.

Lindblom (1980) considera que a maioria dos atos administrativos fazem ou alteram políticas já formuladas ao implementá-las. Um exemplo, no Brasil, vamos tomar como referência a Política Nacional de Saúde Integral da População Negra em que sabemos que as autoridades sanitárias do Poder Executivo deveriam decidir onde, prioritariamente, implementar essa política, quais seriam as especialidades médicas prioritárias, qual seria o perfil demográfico da população alvo, se priorizaria as crianças, os quilombolas, os idosos, as mulheres ou a população negra adulta em geral. Esses procedimentos são definidos por meio de atos administrativos como decretos, portarias, instruções normativas. São atos que formulam, reformulam e muitas vezes ampliam uma política pública já decidida no espaço legislativo. 
Essas lacunas legislativas acontecem, pois, segundo Lindblom (1980), nenhum legislador tem condições de enunciar completamente uma política que cubra todas as contingências, todos os casos possíveis. Assim, prossegue o autor, os formuladores de políticas públicas permitem que os responsáveis pela administração daquela política determinem muitos elementos da concepção apenas esboçada. Esse é um importante espaço de atuação da burocracia.

Logo, corroboramos mais uma vez, pela linha teórica de Lindblom (1980), que a burocracia não atua somente na atividade de pesquisa, na produção de dados e na análise, mas também, como um ator importante na fase de formulação e implementação de políticas públicas, podendo ser uma pedra no caminho da efetividade dessas políticas ou um agente cooperador para o alcance dos resultados previstos pela política. Lindblom (1980) aprofunda a análise ao desenvolver que mesmo que a cientificidade seja considerada apenas um verniz para suavizar a aparência de conflito no processo decisório, tudo é decidido por um critério político, há aqueles que se investem de caráter técnico, mas fazem política para chegar a uma decisão, no nosso caso, seria o técnico-político. Diferentemente da análise weberiana que prega a objetividade nas ações dos técnicos burocratas.

No entanto, uma controvérsia é gerada. Harmon (1995) partindo do pressuposto que há processos de socialização e que por meio das interações pessoais no espaço organizacional é que se dá a tomada de decisão, defende que concentrar a responsabilidade unicamente no indivíduo significa não reconhecer a complexidade dos processos decisórios. Como os indivíduos constroem e reconstroem seus valores e percepções na interação com o outro, a responsabilidade pela tomada de decisão deve ser compartilhada. Se a decisão é compartilhada, ela passa nas mãos de atores situados em diversos pontos no processo de formulação e implementação, inclusive pelos burocratas, como advogamos nesse estudo.

\subsection{Conclusões preliminares}

Neste capítulo nos propomos a discutir o papel da burocracia sob a luz da teoria da burocracia representativa e da teoria weberiana. Weber considera que a burocracia deve possuir autonomia na condução dos seus processos de trabalho; que o seu poder reside no 
conhecimento técnico e no fato de lidar com a máquina estatal há mais tempo do que o dirigente político. A literatura sustenta que a burocracia técnica desempenha um papel importante, sobretudo no processo de implementação e na alteração de rumo de uma política pública. Acreditamos naquilo que a teoria da burocracia representativa nos sugere, que a burocracia espelha a sociedade em que atua. Dificilmente, propostas de políticas de promoção da igualdade racial irão passar por um burocrata sem que ali ele deite o seu olhar crítico favorável ou em desacordo com diretrizes políticas mais amplas.

O pressuposto weberiano da imparcialidade burocrática e a teoria da burocracia representativa são como água e óleo, difícil de se misturar porque a burocracia técnica tem uma relativa autonomia, mas sofre pressões políticas e sociais para atender a determinações em relação a políticas públicas que estão sob a sua atuação. Entretanto, a autonomia da burocracia se dá, sobretudo entre o grupo que exerce cargos em comissão onde o exercício diário gerencial o leva a ter atitudes mais decisórias. Diferentemente, como vimos por meio dos dados, daqueles que não estão à frente de postos gerenciais.

Como discute a teoria da burocracia representativa, fatores como características pessoais, socialização organizacional e ideologias podem vir a influenciar a atitude da burocracia frente a políticas públicas. A teoria da burocracia representativa tende a analisar esses aspectos relacionando atitudes dos burocratas em relação a políticas que beneficiem minorias.

Quer seja pelas pressões políticas e sociais que sofrem ou pelos seus valores e crenças, pressupomos que devido a sua relativa autonomia, os burocratas agem em nome da coletividade quando fazem julgamentos morais e decidem a condução de determinadas políticas públicas. Até que ponto esse burocrata tem uma responsabilidade subjetiva ou representação ativa para com a população negra ao conduzir políticas do interesse de determinados grupos? Haveria um perfil na burocracia que compreenderia a complexidade da sociedade e a legitimidade das interferências políticas na condução do Estado? Se não há uma diversidade de representação na burocracia técnica - sobretudo nas carreiras melhor remuneradas e que tem um maior leque de atuação e influência -, as políticas públicas que podem beneficiar a população negra estão fadadas ao fracasso pela sua paralisia em razão 
da falta de apoio dessa burocracia. Como nos lembrou um dos dirigentes citados, muitas pessoas negras tiveram experiências de vidas semelhantes, caberia aos burocratas de origem social próxima à da população negra alavancar as políticas públicas que beneficiassem a essa população e outras minorias sociais? Se não por esse esforço individual, poderia a burocracia trabalhar no Estado de forma a influenciar o espaço burocrático em decisões que levem à focalização de políticas para promover a igualdade racial? Essas são questões que nos propomos a colocar em evidência por meio dos dados levantados neste trabalho. 


\title{
Capítulo 5 - Teoria da burocracia representativa e análise de variáveis
}

\author{
“...burocracia, para ser democrática, deve representar o grupo a que serve” ${ }^{3}$
}

John Donald KINGSLEY(1944:305)

No capítulo terceiro apresentamos a composição de algumas Carreiras Típicas de Estado objeto de estudo deste trabalho. Observamos que essas carreiras demograficamente estão distantes da representação brasileira. Não é diferente da população dos servidores públicos de forma geral conforme discutiu Osório (2006) onde há uma concentração numericamente de homens e brancos.

Além das análises de Osório (2006), alguns outros dados confirmam a nossa impressão sobre a burocracia brasileira de que não há uma representação passiva dessa burocracia, ou seja, quando o Estado emprega pessoas com características demográficas diversas como um reflexo da população nacional. Vejamos, $46 \%{ }^{64}$ dos servidores civis são do sexo feminino. Essa diferença se acentua quando olhamos para os cargos de alta direção, somente $22 \%$ das mulheres ocupam DAS-5 e 23\%, DAS-6. D’Araújo e Lameirão (2011), ao estudarem sobre a elite dirigente do então Presidente da República Luiz Inácio Lula da Silva também nos confirmam tendências semelhantes quanto à regionalização. Demonstram que entre os DAS-5, DAS-6 e Natureza Especial há uma concentração de dirigentes provenientes da região Sudeste, $41 \%$ no primeiro mandado do governo Lula (2003-2006) e 55\% no segundo mandato (2007-2011), seguido pela região Sul,12\% e 16\%, respectivamente, Centro-Oeste, $8 \%$ e $11 \%$, respectivamente; Nordeste com $8 \%$ e 10\%, respectivamente; e Norte com representação de $3 \%$ e $4 \%$, respectivamente.

As autoras também apresentam dados sobre a baixa incorporação de negros às carreiras e posições de maior prestígio socioeconômico na administração pública. D’Araújo e Lameirão (2011) nos informam que nas duas amostras (2003-2006 e 2007-2011) há

\footnotetext{
63 “....bureaucracies, to be democratic, must be representative of the groups they serve"

${ }^{64}$ Inclui os servidores civis da administração direta, autarquias e fundações do Poder Executivo (inclusive contratos temporários).
} 
sobrerrepresentação de pessoas brancas, $87,2 \%$ e $84,8 \%$, respectivamente, e subrepresentação de pardos, $9,8 \%$ e $11,7 \%$ respectivamente; e pretos, $2 \%$, percentual que aparece nos dois períodos.

Afunilando mais o nosso escopo de estudo, os dados nos instigam a analisar se há uma representação ativa na burocracia brasileira. Se nas tomadas de decisões das políticas públicas, os servidores civis estão propensos a atender aos interesses e às prioridades de grupos de minorias sociais. Se não há representação passiva, haveria uma representação ativa daqueles que não pertencem às minorias sociais? É o que nos propomos a analisar neste capítulo, as decisões tomadas pelos servidores que participaram desta pesquisa sobre políticas de promoção da igualdade racial para a população negra. Se essas decisões estariam em consonância com os interesses da população negra e se haveria um potencial para uma representação ativa desse grupo de servidores?

A Figura 4 apresenta um modelo para o exame da representação ativa da burocracia que participou desta pesquisa. Vamos analisar as variáveis que impactam as ações e as decisões tomadas pelos servidores que responderam ao questionário em relação a políticas públicas para pobres e negros. O modelo integra três classes de variáveis independentes: Características Pessoais, Socialização Organizacional e Percepção da Função do Estado. O modelo está baseado na teoria da burocracia representativa na premissa de que fatores como características pessoais, experiência de socialização vivenciada no espaço governamental e a percepção sobre a função do estado influencia a decisão individual do burocrata.

À despeito da paternidade de Kingsley com a sua publicação Representative bureaucracy: An interpretation of the British civil service de 1944, a teoria da burocracia representativa surgiu como área de estudo acadêmico no final da década de 1960 e ao longo da década de 1970. Conforme nos explica Dolan e Rosenbloom (2003) com o movimento "reinventando o governo" (também conhecido como a Nova Gestão Pública) ${ }^{65}$, na década de 1990, houve uma aglutinação na academia em torno de pesquisas sobre a burocracia representativa na tentativa de monitorar com um modelo padrão o impacto das características pessoais no

\footnotetext{
${ }^{65}$ Programa do ex-presidente dos Estados Unidos Bill Clinton e liderado pelo seu ex-vice-presidente Al Gore na década de 1990
} 
desempenho dos servidores públicos, particularmente naquelas atividades que exigiam uma considerável discricionariedade.

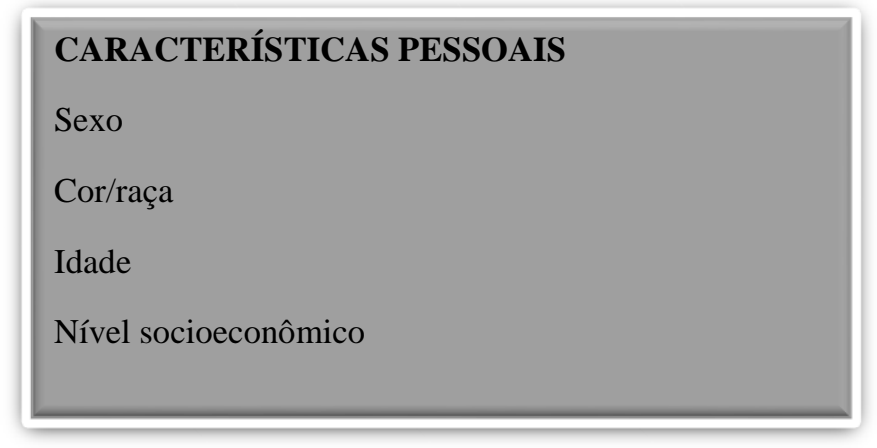

\section{SOCIALIZAÇÃO ORGANIZACIONAL}

Tempo de exercício na carreira

Experiência em gestão

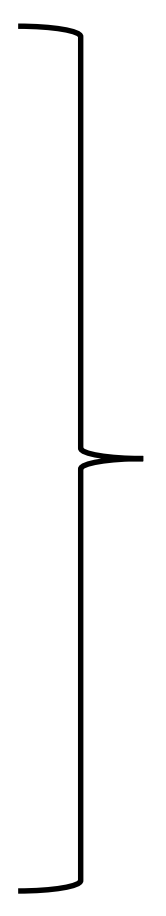

Decisão sobre políticas de promoção da igualdade racial para a população negra (PP_Negros)

PERCEPÇÃO SOBRE O PAPEL DO ESTADO

Figura 4 - Modelo de análise para representação ativa 
Meier e Nigro (1976) estudaram e teceram críticas ao modelo da teoria da burocracia representativa. Eles explicam que, geralmente, o modelo consiste em quatro variáveis associadas em um desenvolvimento sequencial: origem social, experiência de socialização, atitudes e comportamentos (Figura 5). Primeiro, diferenças na origem social são os maiores fatores que impactam as experiências de socialização; segundo, experiência de socialização tem um forte impacto sobre atitudes políticas; terceiro, atitudes estão fortemente relacionadas com o comportamento atual. Em suma, o modelo presume que a origem social dos funcionários afeta a sua experiência de socialização, que por outro lado afeta as suas atitudes, crenças, valores, percepções que, finalmente, influencia em como eles tomam suas decisões administrativas. Os achados de Meier e Nigro (1976) indicam que a origem social e a organização governamental - como espaço de socialização profissional - tem um impacto nas atitudes. Entretanto, é o local de trabalho que melhor prediz a atitude do burocrata nos resultados do estudo desses autores.

\section{Origem social}

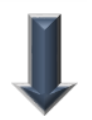

Socialização

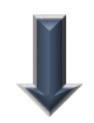

\section{Percepções}

\section{Comportamento}

Figura 5 - Modelo da teoria da burocracia representativa 
Thompson (1978), no seu estudo sobre o comportamento de servidores públicos em relação a contratação de minorias para postos de trabalho, compara o grau de variação da receptividade à contratação de minorias. Ele faz isso tomando vários elementos sociopolíticos e ocupacionais. Esse autor trabalha com variáveis que procuram explicar que as atitudes dos servidores civis em relação à contração de minorias derivam fundamentalmente de percepções quanto às preferências de grupos externos e as pressões sociais que exercem. Outros fatores são as características pessoais dos servidores públicos que os definem como pertencentes a algum grupo social (ex: raça, sexo, região); também as suas crenças e convicções sobre igualdade.

Thompson (1978) trabalhou com dados de 1975 derivados de uma pesquisa com dirigentes de recursos humanos na administração pública dos Estados Unidos ${ }^{66}$. O autor afirma que esses dirigentes exercem uma alta influência sobre as decisões que afetam o como e em que quantidade minorias sociais são contratadas para determinados postos de trabalho no Estado. Esses dirigentes públicos selecionam o tipo de testes que serão usados e como esses testes serão pontuados, aspectos que podem influenciar a capacidade das minorias sociais em obterem trabalho na avaliação de Thompson (1978). Além disso, segundo o autor, o comportamento desses dirigentes públicos modela o custo político e social que líderes de minorias sociais e outros pagam na tentativa de forçar que o Estado empregue pessoas que pertencem a minorias sociais. O autor lista como custos políticos e sociais o tempo gasto e a frequente judicialização que nem sempre favorece ao candidato.

O estudo de Thompson (1978) conclui que atributos pessoais tem baixo poder de predição sobre as atitudes dos servidores públicos civis em contratar minorias sociais. Esse é um resultado que contradiz a teoria da burocracia representativa que defende que grupos sociais ganham substantivamente representação nos órgãos públicos se os indivíduos desses grupos adquirirem posições de influência dentro da burocracia pública. A hipótese sobre as pressões sociais e percepções de grupos externos também não se confirmou no estudo de Thompson (1978) , ou seja, não se mostrou um forte preditor. Por outro lado, os dados analisados pelo

\footnotetext{
${ }^{66}$ Thompson (1978) enviou questionários para 1.506 dirigentes públicos. Essa amostra foi obtida de uma seleção aleatória de um total de 2.073 indivíduos, membros da Associação Internacional de Recursos Humanos. Do total de questionários enviados, $65 \%$ retornaram (979), sendo 65\% da administração municipal, $28 \%$ dos estados e $7 \%$ da burocracia federal.
} 
autor o leva a concluir que a consciência do servidor sobre desigualdade social é o que mais influencia na contratação de pessoas que pertencem a minorias sociais.

Rehfuss (1986) estudou altos executivos da administração pública do Estado da Califórnia, membros da carreira California Career Executive Assignment (CEA), o autor comparou esses executivos aos membros da carreira Senior Executive Service (SES) do poder público federal dos Estados Unidos ${ }^{67}$. O autor compara a representação entre os servidores civis da CEA, SES e de outros estados; compara também a diferença entre a visão das mulheres e de outras minorias sociais membros da CEA que ocupam altas posições na burocracia com a de seus colegas dirigentes homens e brancos membros da CEA; analisa ainda como as mulheres e as outras minorias sociais membros da CEA veem o seu papel na gestão pública. Naquilo que nos interessa para este estudo, o autor procura saber se a representação passiva de mulheres e outras minorias leva a uma representação ativa dos seus grupos de interesse. Rehfuss (1986) considera que nenhuma conclusão é possível, mas sugere que a ideologia sobre o que seja atuar gerencialmente leva as mulheres e outras minorias sociais a terem perspectivas similares aos dos seus colegas homens e brancos.

Numa linha de resultados opostos, mas adotando a mesma base teórica e metodologias de análise, alguns estudiosos defendem a influência de fatores como origem social e experiência de socialização nas decisões sobre políticas públicas voltadas a minorias sociais. ColemanSelden (1998) pondera a relação entre burocracia passiva e burocracia ativa no órgão governamental responsável pelo programa de crédito à habitação rural nos Estados Unidos - Farmers Home Administration's (FmHA) Rural Housing Loans program ${ }^{68}$. O programa é executado de forma descentralizada para os municípios onde há um supervisor cujas condicionalidades para ser beneficiário do crédito é ser morador da área rural e possuir uma renda mínima aferida conforme o município de residência. Esse programa de crédito foi selecionado por Coleman-Selden (1998) porque, segundo ela, atende condições perfeitas para explorar a relação entre representação passiva e ativa e os resultados e produtos das políticas públicas.

\footnotetext{
${ }^{67} \mathrm{O}$ autor realizou 85 entrevistas com servidores da CEA selecionados aleatoriamente, $15 \%$ mulheres e $25 \%$ de outras minorias sociais. Cerca de $40 \%$ dos servidores da CEA foram entrevistados.

${ }^{68} \mathrm{~A}$ autora enviou pelos correios um questionário aos supervisores do FmHA nos municípios. Recebeu 234 questionários respondidos que representam $61 \%$ da amostra, deste grupo, 184 responderam o questionário completamente.
} 
Uma dessas condições é a considerável discricionariedade da tomada de decisão, pois os supervisores são responsáveis por examinar as solicitações de crédito; pela entrevista dos potenciais beneficiários e por decidir quem são os beneficiários do crédito rural de habitação. Na tomada de decisão esse supervisor não recebe nenhuma orientação direta dos órgãos superiores, na pesquisa da autora, $94 \%$ dos supervisores municipais afirmaram que possuem uma considerável discricionariedade na alocação dos recursos. Para a autora, algumas decisões são baseadas em fatores objetivos. Indivíduos que excedem à renda mínima ou aqueles que não tem perfil financeiro para pagar o empréstimo serão classificados como inelegíveis para o programa. Similarmente, candidatos que estão dentro de uma faixa de renda mínima a moderada, que têm um bom histórico de crédito e uma boa capacidade de pagamento podem ser classificados como elegíveis para o programa. Mas, candidatos com um histórico de crédito pobre e/ou um emprego irregular podem ir para qualquer direção. É um caso que requer do supervisor tomar uma decisão baseada em seu julgamento pessoal, assim um número de fatores subjetivos pode entrar na tomada de decisão. Coleman-Selden (1998) cita um exemplo tomado de uma pesquisa de Wyatt e Phillips (1988) sobre uma supervisora de crédito que negou um empréstimo a uma família porque ela viu a família comendo em um restaurante de fast-food. "Comer fora", a supervisora disse, "significa não fazer uma boa gestão do dinheiro e ainda é uma péssima nutrição" (WYATT; PHILLIPS, 1988:92 apud Coleman-Selden, 1998).

No seu estudo, Coleman-Selden (1998) seleciona um conjunto de fatores que sintetizam variáveis que mensuram origem demográfica, experiência de socialização, valores, atitudes, crenças e tomadas de decisão sobre políticas de crédito habitacional rural. Ao analisar dados de recrutamento de 1984, 1986, 1990 e 1994, a autora afirma que entre as minorias sociais, apesar de ter aumentado o recrutamento, negros, asiáticos, hispânicos e mulheres têm uma sub-representação na FmHA proporcionalmente a sua presença na população em geral. Apenas os indígenas, denominados de americanos nativos, é que possuem uma sobrerrepresentação na FmHA em relação à população em geral. O principal achado da autora é que o aumento no número de pessoas empregadas na FmHA que pertencem a minorias sociais fazem uma real diferença em como os recursos são alocados. Nos municípios onde há uma alta porcentagem de supervisores negros, hispânicos e asiáticos há 
mais decisões favoráveis a cidadãos negros, hispânicos e asiáticos respectivamente. Raça e gênero foram fortes preditores na representação ativa. Pelas análises de Coleman-Selden (1998) houve um aumento da representação de mulheres e outras minoriais sociais na FmHA não apenas em postos administrativos, mas em funções gerenciais, impactando na decisão burocrática e, sobretudo, no exercício político.

Brudney, Hebert e Wright (2000) examinam o potencial de representação ativa de gestores públicos responsáveis por instituições governamentais em 50 estados nos Estados Unidos ${ }^{69}$. Os autores trabalham com recorte de gênero e raça e a relação entre a percepção desses gestores sobre aspectos organizacionais da instituição que comandam e as suas atitudes no processo decisório. Os aspectos organizacionais que são avaliados pelos autores são a capacidade técnica e administrativa da organização, a reputação e o desenvolvimento organizacional. O que os autores desejam conhecer é se a representação ativa opera diretamente entre os executivos estatais. Querem saber se o comportamento difere entre os gestores públicos pertencentes a minorias sociais dos seus colegas homens brancos; e se há alguma influência das funções organizacionais sobre as decisões das mulheres e dos gestores não-brancos. A análise empírica realizada pelos autores sugere que raça e gênero impactam a atitude burocrática e em certas situações há influência de aspectos organizacionais. Os testes estatísticos realizados pelos autores demonstram que os gestores públicos não-brancos e as mulheres gestoras públicas diferem dos seus colegas com respeito à importância dos valores organizacionais, como desenvolvimento e competência organizacional; e gestão equilibrada $^{70}$. Os gestores públicos não-brancos deram uma importância maior ao desenvolvimento organizacional e a abraçaram firmemente a competência organizacional.

Indo um pouco além, Bradbury e Kellough (2008) defendem que cidadãos e gestores públicos negros tendem a apoiar ações governamentais que focam na população negra mais do que cidadãos e gestores públicos brancos; e que os gestores públicos negros são mais propensos a adotar um papel representativo da população negra do que os gestores públicos

\footnotetext{
${ }^{69}$ Os autores distribuíram questionários para os dirigentes máximos de 93 tipos de órgãos públicos dos 50 estados. Foram 3.365 dirigentes com uma taxa de resposta de 37\% (1.229 questionários respondidos) .

${ }^{70}$ No trabalho dos autores, os indicadores que compõem essas dimensões são: desenvolvimento organizacional - crescimento organizacional e estabilidade orçamentária; competência organizacional - efetividade, alta produtividade, qualidade, eficiência e atendimento ao cliente; gestão equilibrada - reputação organizacional e liderança organizacional.
} 
brancos, ou seja, propensos a atender demandas focadas na população negra. Estas conclusões são extraídas de um estudo ${ }^{71}$ realizado pelos autores onde analisam as atitudes de cidadãos e gestores públicos em relação a políticas voltadas à população negra. Os autores utilizam uma série estatística que permite comparar as atitudes entre gestores públicos de administração municipal e a população a quem servem. Bradbury e Kellough (2008) concluíram que a variável raça foi um forte preditor na coesão das atitudes. Outras variáveis como sexo, nível educacional, ideologia política e o feedback da comunidade negra foram, também preditores importantes para aferir a coesão entre as atitudes dos gestores públicos e os cidadãos negros.

Num outro espectro de análise na intenção de trazermos outros estudos que tratam da burocracia representativa, Van de Walle, Groeneveld e Vandenbussche (2013) analisam o desafio da administração pública belga em promover a representação burocrática pela clivagem cultural e linguística entre os flamengos que falam a língua holandesa e os valões de língua francesa ${ }^{72}$. Os autores esclarecem que ao longo do tempo, os dois grupos linguísticos foram beneficiados com direitos e proteção em diferentes aspectos nos setores públicos da Bélgica. Entretanto, a Bélgica tem se tornado um país de alta diversidade étnica e cultural de minorias sociais (imigrantes e seus descendentes) o que instiga os autores a problematizarem o desafio de se estabelecer uma burocracia representativa no Estado belga. As análises das estatísticas descritivas que os autores realizam os levam a concluir que, com exceção da composição feminina, há uma lacuna de representação de outras minorias sociais. Bem como, a ocupação de postos na administração belga em vez de refletir a composição mais ampla da população, $42 \%$ da língua francesa e 58\% da língua holandesa, acabam por representar $47 \%$ e $53 \%$ respectivamente.

\footnotetext{
${ }^{71}$ Para a comparação, os autores analisaram questionários respondidos por uma amostra de 1.000 cidadãos negros moradores da cidade de Athenas e Clarke County do Estado da Georgia, assim como uma segunda amostra composta por 1.000 pessoas de uma pesquisa de um único setor censitário onde havia uma alta proporção de negros (70\%). Houve uma taxa de resposta de 33,8\%, sendo que $45 \%$ dos respondentes se autodeclararam negros e $55 \%$ se identificaram como brancos. A amostra da administração local foi focada nos servidores que exerciam funções em altos postos. $\mathrm{O}$ critério para seleção era que esses servidores tivessem autoridade e discricionariedade para tomada de decisão. A amostra total foi de 787 servidores, sendo 77,4\% identificados como brancos e 20,5\% como negros. Gestores e cidadãos de outros grupos raciais foram excluídos da análise desses autores.

72 Os autores analisam dados de recursos humanos da administração pública da Bélgica disponível em www.pdata.be. Os dados incluem os serviços públicos federais (antigos ministérios - FPS) e todos os Serviços Públicos Programáticos (PPS), com exceção das agências, instituições científicas federais e instituições de segurança social.
} 
O estudo de Egeberg, Gornitzka e Trondal (2014) é uma outra vertente de exploração do perfil demográfico de uma população e seu comportamento quanto à representação burocrática. Os autores analisaram os funcionários lotados no Secretariado do Parlamento Europeu, órgão de administração do Parlamento Europeu, e aqueles que compunham os partidos políticos europeus ${ }^{73}$. Este estudo traçou duas linhas de investigação, primeiro obter um mapa demográfico sobre o perfil desses funcionários com relação à nacionalidade, sexo, nível educacional, trajetória profissional e plano de carreira. Segundo, analisar se e em que extensão o perfil demográfico desses servidores influenciam o seu comportamento nas questões nacionais e europeias. Os autores consideraram que os funcionários do Secretariado do Parlamento Europeu e dos partidos políticos europeus tomam parte do processo de decisão. Enumeram que $80 \%$ dos funcionários do Secretariado atuaram muito além das questões técnicas e administrativas com o envolvimento político direto junto ao parlamentar europeu. Os autores alertam que no contexto europeu, a nacionalidade daqueles que atuam no Parlamento Europeu pode ser um fator de influência, pendendo a balança para um lado ou para o outro. As análises de Egeberg, Gornitzka e Trondal (2014) levam os a concluírem que quanto maior o tempo de serviço, menor a importância que os servidores de forma geral dão para as questões nacionais, portanto, maior a ênfase nos assuntos europeus. Por outro lado, aqueles que almejam uma carreira nacional tendem a atribuir menos peso a questões europeias. Os burocratas oriundos dos países membros que se filiaram recentemente à União Europeia tendem a não priorizar os assuntos nacionais de sua própria origem. Quanto ao vínculo funcional, aqueles que estavam atuando nos partidos políticos da União Europeia mostraram uma maior inclinação para os assuntos nacionais do que os seus colegas lotados no Secretariado do Parlamento Europeu.

Essas experiências de estudos empíricos relatadas são desenvolvidas sob o contexto social dos Estados Unidos e da Europa. O que nos leva a ponderar os seus resultados ao comparar com a realidade brasileira. Inicialmente neste capítulo, dados demonstraram que não temos uma representação passiva da população negra na burocracia do poder executivo, pois os negros ali presentes são proporcionalmente sub-representados comparativamente a sua participação na população brasileira. Coleman-Selden (1998) nos apresenta um método para

\footnotetext{
${ }^{73}$ Os autores enviaram questionários para 327 funcionários dos partidos políticos europeus e para 209 funcionários do Secretariado do Parlamento Europeu, com uma taxa de resposta de 16\% e 33\% respectivamente.
} 
calcular a representatividade na burocracia pública classificado como índice de representação. Essa taxa é calculada da seguinte forma:

$$
\text { Índice de Representação }=\frac{\% \text { do grupo dentro na organização }}{\% \text { do grupo dentro da população relevante }}
$$

A taxa 1,0 significa que a composição da organização corresponde perfeitamente com a população relevante. Podemos entender como população relevante, a população nacional, população local ou uma outra população de referência. Vamos retomar o estudo de Osório (2006) sobre as desigualdades raciais e de gênero no serviço público. O autor encontrou que 35\% dos servidores no Poder Executivo da Administração Direta e Indireta são negros, enquanto $63 \%$ se declararam brancos. Conforme o índice de representação de ambos os grupos no Poder Executivo da Administração Direta e Indireta temos uma sub-representação da população negra $(0,69)$, enquanto a população branca é sobrerrepresentada em $1,3^{74}$. Quando tomamos os dados daqueles que participaram da nossa pesquisa, no caso a representação desses dois grupos nas carreiras, temos os seguintes índices: 0,5 para a população negra e 1,5 para a população branca. Vemos, portanto, que a população negra está distante de uma participação importante nos postos de trabalho do Poder Executivo, a sua presença decresce ainda mais nos postos de melhor remuneração do Estado.

No Brasil, a discussão sobre implementação de políticas de ação afirmativa na educação e no mercado de trabalho suscitaram evidências de que não há um comportamento de grupos raciais em ser favorável ou não favorável a essas propostas. Estudos brasileiros apontam que os grupos mais pobres e menos escolarizados são mais favoráveis a políticas de promoção da igualdade racial, enquanto os mais ricos e mais escolarizados apresentam opiniões contrárias, quer sejam negros ou brancos (TELLES; BAILEY, 2002). Guimarães (2002a) discute que essas percepções expressam privilégios que estão bem estruturados e sedimentados nos grupos raciais e de gênero no Brasil.

Isso significa que tais privilégios orientam a sua reprodução e ampliação através de discriminações (e não que não há discriminação racial e de gênero); significa que a paz racial é, no Brasil, um pacto de

\footnotetext{
${ }^{74}$ Índice de representação da população negra $=35 \% / 50,7 \%=0,69$; índice de representação da população branca $=63 \% / 47,7 \%=1,3$
} 
privilegiados, negros e brancos (e não que os que não aceitam tal pacto queiram a guerra racial ou sejam intelectual e culturalmente grosseiros) (GUIMARÃES 2002a:72-73)

Diante da literatura sobre teoria da burocracia representativa, optamos pelo modelo apresentado na Figura 4. Isso não quer dizer que a incorporação de outras variáveis fuja dos princípios teóricos da burocracia representativa. Egeberg, Gornitzka e Trondal (2014), por exemplo, trabalharam nos seus estudos com a nacionalidade, enquanto Van de Walle, Groeneveld e Vandenbussche (2013) com a diversidade cultural e linguística. No nosso entender, as variáveis que foram eleitas são apropriadas para o objetivo do nosso estudo e devem ser testadas para analisar a influência sobre a decisão dos servidores que participaram deste trabalho em ser favorável ou não a políticas de promoção da igualdade racial para a população negra.

Iremos, agora, analisar estatisticamente as variáveis que sintetizam características pessoais, socialização organizacional e percepção sobre a função do Estado. Questionamos se fatores demográficos como sexo, cor/raça ou idade diferenciam a percepção dos nossos participantes quanto a políticas para a população negra. Se há diferença de percepções entre aqueles que tem um maior tempo de trabalho no Estado e de experiência em gestão na administração pública. Finalmente, uma outra vertente é como os nossos participantes consideram que o Estado deve atuar. Se a definição que eles possuem sobre a função do Estado influencia na sua percepção sobre políticas de promoção da igualdade racial.

\subsection{Conceitos e operacionalização das variáveis}

\subsubsection{Variáveis independentes (VI)}

5.1.1.1. Sexo. O sexo do respondente é uma variável significativa nos estudos sobre atitudes burocráticas no âmbito da teoria da burocracia representativa (BRADBURY; KELLOUGH, 2008; BRUDNEY; HEBERT; WRIGHT, 2000; NAFF; CRUM, 2000; KEISER et al, 2002; DOLAN, 2002). Trabalhamos com a variável sexo considerando a autoclassificação dos entrevistados em feminino ou masculino. Neste estudo não ignoramos que a categoria sexo está baseada em construções de gênero histórica e concretas conforme defende Stolcke (2000). Em razão dessas relações tínhamos uma hipótese de que as mulheres poderiam ter 
uma tendência a serem mais favoráveis a políticas de diminuição da desigualdade racial. Por outro lado, sublinhamos que o feminismo negro denuncia que as feministas brancas não reconhecem e não defendem as bandeiras de interesse da população negra, sobretudo, da mulher negra (AZERÊDO, 2008; BAIRROS, 2008; HOOKS et al, 2008). O que essas autoras manifestam é que grande parte das teorias feministas advém de mulheres em situação privilegiada, que nunca tiveram a experiência de uma vida de desvantagem social. Em referência à teoria da burocracia representativa, autores como Hughes e Tuch (2003) e Steinbugler e al (2006) sugerem que não há nenhuma evidência, ou quando há é muito baixa, de que a diferença de gênero impacta na atitude do indivíduo em relação a políticas governamentais favoráveis à população negra. Apostamos, entretanto, que as mulheres, pelas suas características sociais, construídas a partir da sua experiência de gênero, poderiam ter uma opinião favorável a ações de combate à desigualdade racial. O fato de ser mulher, numa sociedade marcadamente sexista, poderia levar a experiências históricas diferentes da dos homens o que poderia influenciar o posicionamento das mulheres em relação a outros grupos de minorias sociais.

5.1.1.2. Cor/Raça. Raça é uma das variáveis que se faz mais presente na literatura sobre burocracia representativa. Os respondentes da pesquisa se autoclassificaram como da cor e/ou raça branca, preta, parda, amarela e indígena, categorias previamente listadas conforme as utilizadas pelo IBGE. Estamos trabalhando com o conceito cor e/ou raça como uma categoria nativa, que tem sentido no mundo prático, conforme analisa Guimarães (2003). Alguns estudos nos Estados Unidos confirmam a importância da cor/raça na administração pública (BRADBURY; KELLOUGH, 2008; BRUDNEY; HEBERT; WRIGHT, 2000; DOLAN; ROSENBLOOM, 2003; MEIER; WRINKLE; POLINARD, 1999; MEIER; NIGRO, 1976; MEIER, 1975; NAFF; CRUM, 2000; THEOBALD; HAIDER-MARKEL, 2009; THOMPSON, 1978; WINN, 1989) . Meier, Wrinkle e Polinard (1999), por exemplo, concluíram em um estudo conduzido em 350 escolas públicas que tanto os estudantes membros de minorias raciais e quanto aqueles que não pertenciam a grupos sociais minoritários tinham um melhor desempenho quando havia a presença de professores negros e latinos nas escolas públicas. Apesar de haver baixas evidências no cenário nacional sobre a relação entre políticas de promoção da igualdade racial voltada à população negra e o perfil demográfico populacional, as poucas pesquisas existentes afirmam que anos de estudo é a variável que tem maior relevância na 
defesa de políticas afirmativas para a população negra. Às mesmas conclusões chegam Telles e Bailey (2002) e são analisadas por Guimarães (2002a) conforme citamos no início deste capítulo. Assim, quanto mais elevada a escolarização de brancos e negros no Brasil, menor a porcentagem desses grupos em apoiar políticas promotoras da igualdade racial. Diferentemente, negros e brancos nos Estados Unidos se posicionam com bastante evidência sobre políticas favoráveis à população negra. Lá os negros se posicionam majoritariamente favoráveis a ações voltadas à população negra. Enquanto a população branca tem opiniões contrárias. Podemos entender que há um forte sentimento de solidariedade entre os negros estadunidenses quando estimulados a opinar sobre ações favoráveis a seu grupo (KINDER; WINTER, 2001; TELLES; BAILEY, 2002). Iremos analisar se há alguma associação entre cor e/ou raça de nossos respondentes e a opinião sobre políticas de promoção da igualdade racial.

5.1.1.3. Idade. Os estudos fundamentados na teoria da burocracia representativa também identificaram a idade como uma variável significativa nas atitudes dos burocratas (BRUDNEY; HEBERT; WRIGHT, 2000; COLEMAN-SELDEN; BRUDNEY; KELLOUGH, 1998; THEOBALD; HAIDER-MARKEL, 2009; THOMPSON, 1978). Coleman-Selden (1998) defende que os indivíduos de uma mesma faixa etária têm experiências históricas similares e podem compartilhar percepções de sua geração. Meier e Nigro (1976) registram que os burocratas mais velhos tendem a não apoiar políticas públicas voltadas para as minorias sociais. Pensamos que no nosso contexto nacional, acontecimentos de dez ou quinze anos atrás podem vir a influenciar a percepção dos burocratas, sobretudo daqueles que entraram no Estado recentemente. Esses tiveram ou acompanharam os debates sobre políticas de promoção da igualdade racial fora do Estado e agora têm a oportunidade de vivenciar a formulação e a execução dessas políticas.

5.1.1.4. Socialização Organizacional. Socialização é um processo contínuo, as pessoas mudam ao longo de sua vida. À medida que elas mudam nas suas posições sociais podem mudar também as suas visões de mundo. Quando pensamos em trajetória profissional estamos querendo aferir até que ponto a experiência social dos burocratas na administração pública poderia ser um determinante na percepção sobre políticas de promoção da igualdade racial. Aspectos como tempo de carreira e experiência em gestão são considerados para 
explorarmos a socialização no Estado dessa burocracia que estamos estudando. Nos estudos de Meier e Nigro em 1976, os autores encontram uma forte relação entre socialização organizacional e as atitudes dos burocratas; muito mais significativa do que origem social e o perfil demográfico dos servidores públicos. A mesma conclusão chega Thompson (1978) em seus estudos. Por outro lado, Dolan (2002) defende que a socialização organizacional se sobrepõe ao gênero quando se trata de analisar as atitudes e preferências dos burocratas sobre prioridade de gastos na administração pública. KEISER et al (2002) argumentam que o processo de socialização organizacional impacta na representação passiva em se tornar uma representação ativa, ou seja, no caso do estudo dos autores, há forte possiblidade de as mulheres estarem mais suscetíveis a se engajar numa representação ativa para as mulheres devido a experiência compartilhada profissionalmente. Coleman-Selden (1998) analisou que o tempo de experiência no serviço público é negativamente associado com o papel representativo de minorias sociais, o que significa dizer que quanto mais tempo de serviço um burocrata tem no Estado, maior a chance dele não exercer um papel representativo de minorias sociais. Outros indicadores que a autora trabalhou dentro do fator socialização organizacional - tempo de capacitação e tempo de experiência em gestão - não apresentaram nenhuma relação com o exercício de uma função representativa das minorias sociais.

5.1.1.5. Função do Estado. Uma outra variável que vamos trabalhar na relação burocrata e políticas de promoção da igualdade racial é a percepção da função do Estado. Para entender o papel do Estado nas atitudes dos burocratas, a teoria da burocracia representativa normalmente relaciona identificação partidária, entre ser conservador ou liberal. Os estudos encontram que aqueles que se inclinam para uma orientação mais liberal, ou progressista, identificando-se com o Partido Democrata nos Estados Unidos, teriam uma maior tendência a apoiar políticas que beneficiam minorias sociais (BRUDNEY; HEBERT; WRIGHT, 2000; NAFF; CRUM, 2000; THOMPSON, 1978). Aberbach, Putnam e Rockman (1981), num outro tipo de abordagem sobre a burocracia, encontram elementos para apontar como as dimensões ideológicas entre políticos e burocratas diferem. No estudo realizado por esses últimos autores, os políticos são muito mais favoráveis à intervenção estatal do que os burocratas. Os burocratas fluem entre uma postura mais ao centro, um equilíbrio entre a intervenção estatal e a iniciativa privada. Argumentam que os burocratas tem essa fluidez em razão de suas relações perenes e por operar dentro do Estado, o que faz com que os 
burocratas tenham uma postura menos solidificada.

5.1.1.6. Nível socioeconômico. A ocupação do pai é um fator que a teoria da burocracia representativa trabalha no conjunto das variáveis demográficas. Meier e Nigro (1976) identificaram que a alta administração pública tem uma forte origem nas classes médias altas. Isso leva uma discrepância de origem social, o que na análise da literatura sobre burocracia representativa gera um déficit de interesses representados no controle do Estado (KINGSLEY, 1944). Além da teoria da burocracia representativa, Aberbach, Putnam e Rockman (1981), ao analisar o perfil dos burocratas e políticos das democracias ocidentais, afirmam que a origem social tem uma grande influência no processo de recrutamento da elite do serviço público, ou seja, entre aqueles que ocupam os altos postos e participam ou tomam decisão. No esquema elaborado pelos autores, eles procuram demonstrar que a origem social impacta nas oportunidades educacionais; consequentemente, o sucesso educacional impacta no recrutamento da elite do Estado. Não nos prendemos apenas na ocupação do pai para analisar a origem social dos respondentes conforme descrevemos no capítulo segundo e terceiro deste trabalho. Utilizamos a literatura que trata sobre nível socioeconômico de forma a encontrar o melhor operador para medir a distinção entre os nossos respondentes. A unidade de medida foi o International Socio-Economic Index (ISEI) que nos nossos dados empíricos variou de 16, atribuído a funções de ajudante de serviços gerais e atividades domésticas, a 90, atribuído a função de juiz de direito. A maior frequência ficou com o índice 51, empresário a pequenos empresários, servidor público de nível intermediário e trabalhadores bancários. Conforme podemos constatar na distribuição do Gráfico 9 não há concentração percentual no ponto de origem, zero, menos de $20 \%$. Verificamos também que há uma grande amplitude de ocupações dos pais e das mães de nossos respondentes, sem, entretanto, afetar a posição da origem social dos nossos participantes situada nos estratos de médio a alto. No capítulo segundo, realizamos essa análise a partir do método de classificação de nível socioeconômico selecionado e dos dados levantados. 


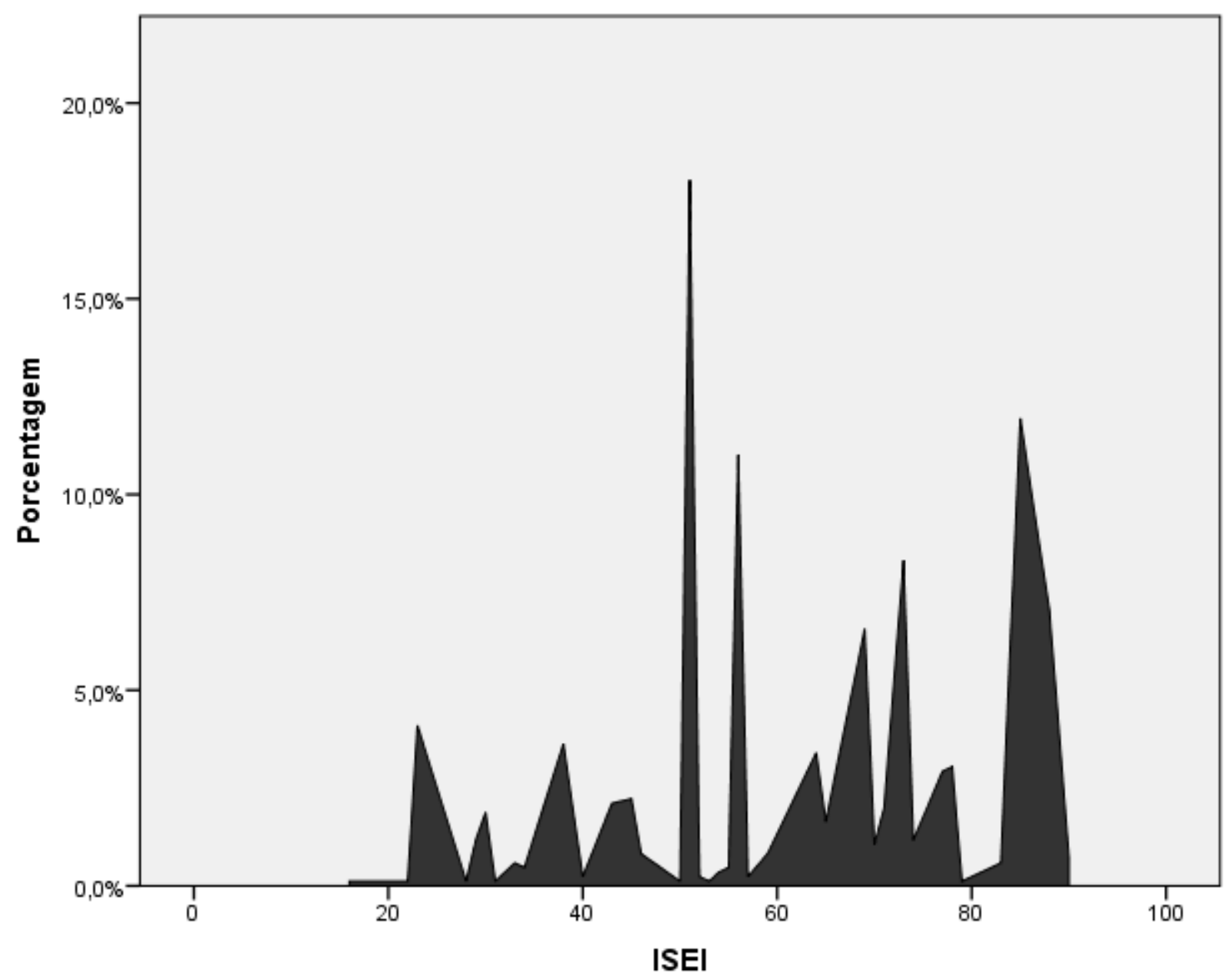

Gráfico 9 - Nível socioeconômico dos pais dos participantes da pesquisa

\subsubsection{Variável Dependente (VD)}

\subsubsection{Coerência da variável dependente}

Utilizamos a Análise Fatorial (FA) para reduzirmos o número de variáveis dependentes e constituirmos um único fator. Esse fator irá nos guiar na análise sobre a influência das variáveis independentes no comportamento dos servidores da Carreiras Típicas em relação às propostas de políticas públicas para a população negra e para a população pobre. Pasquali (2012) nos esclarece que a Análise Fatorial é um método útil para transformar um conjunto de variáveis em outro conjunto; reduz o número de variáveis e procura explicar a maior parte 
da variância das variáveis originais. $\mathrm{O}$ autor explica com exemplos simples a função dos Componentes Principais e consequentemente da Análise Fatorial:

Se dois itens medem coisas diferentes, não relacionadas entre si (um se refere a gostar de frutas e outro a preferência política, por exemplo), então os sujeitos vão responder a um item de uma forma e ao outro de outra forma, de tal modo que, no fim, os itens aparecem totalmente sem relação um com o outro (...). Entretanto, se os dois itens estão medindo a mesma coisa (digamos, gostar de frutas, então o sujeito que concorda com um item concordará também com o outro, e o que discorda de um discordará do outro também, e assim por diante” (PASQUALI 2012:43-44).

Assim, o que fizemos foi utilizar a Análise Fatorial para alcançar o menor número possível de variáveis hipotéticas, ou seja, fatores, de forma a explicar a maior porcentagem possível da covariância entre as variáveis.

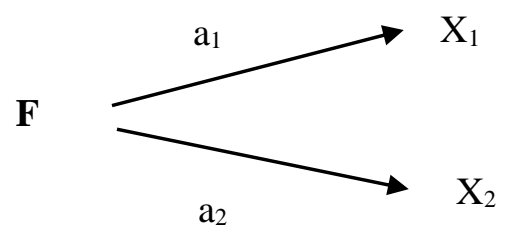

Figura 6 - Representação de um modelo fatorial75

${ }^{75} \mathrm{X}_{1}$ e $\mathrm{X}_{2}=$ variáveis observáveis 1 e 2;

$\mathrm{F}$ = variável-fonte comum, ou fator comum, às duas variáveis observáveis. É comum a mais de uma variável observável;

$a_{1}$ e $a_{2}=$ pesos (cargas) das variáveis observáveis nas variáveis-fonte, ou no fator comum. 
Esclarecemos que os Quadros 3 e 4 apresentam as definições das sínteses das variáveis dependentes deste estudo. No Quadro 3 apresentamos as variáveis que expressam as propostas de políticas públicas para a população negra.

\section{Quadro 3 - Síntese das variáveis que representam as propostas de políticas públicas para a população negra (PP_Negros)}

Síntese das variáveis

I. Negros_CrecheEscola

II. Negros_CursinhosVestibular

III. Negros_IESAcesso

IV. Negros_UnidadesSaúde

V.

Negros_FundoOrçamentárioFinanceiro

VI.

Negros_EntidadesCulturaisEsportivas

VII. Negros_FábricaÁreas

VIII. Negros_ConcursoPúblico
Variáveis

Que o Estado gaste mais dinheiro nas creches e escolas localizadas em áreas onde a maioria dos moradores é da população negra.*

Que o Estado gaste mais dinheiro apoiando cursinhos prévestibulares promovidos por ONGs para estudantes negros/as.

Que o Estado estimule, financeiramente, as Instituições de Ensino Superior Públicas a implantar programas para ampliar o acesso de estudantes negros/as ao ensino superior.

Que o Estado gaste mais dinheiro nas unidades de saúde localizadas nas áreas em que a maioria dos moradores é da população negra.

Que o Estado institua um fundo orçamentário e financeiro para a implementação de políticas que possam elevar a condição socioeconômica da população negra no Brasil.

Que o Estado incentive financeiramente as entidades culturais e esportivas localizadas nas áreas em que a maioria dos moradores é da população negra.

Que o Estado incentive as empresas a construírem fábricas em áreas onde a maioria dos moradores é de da população negra.*

Que o Estado reserve vagas nos concursos públicos para pessoas negros/as.

*Essas perguntas foram retiradas da publicação "A cabeça do brasileiro" de Alberto Carlos Almeida (2007). 
O Quadro 4 ilustra as variáveis que sintetizam as propostas de políticas públicas de combate à pobreza.

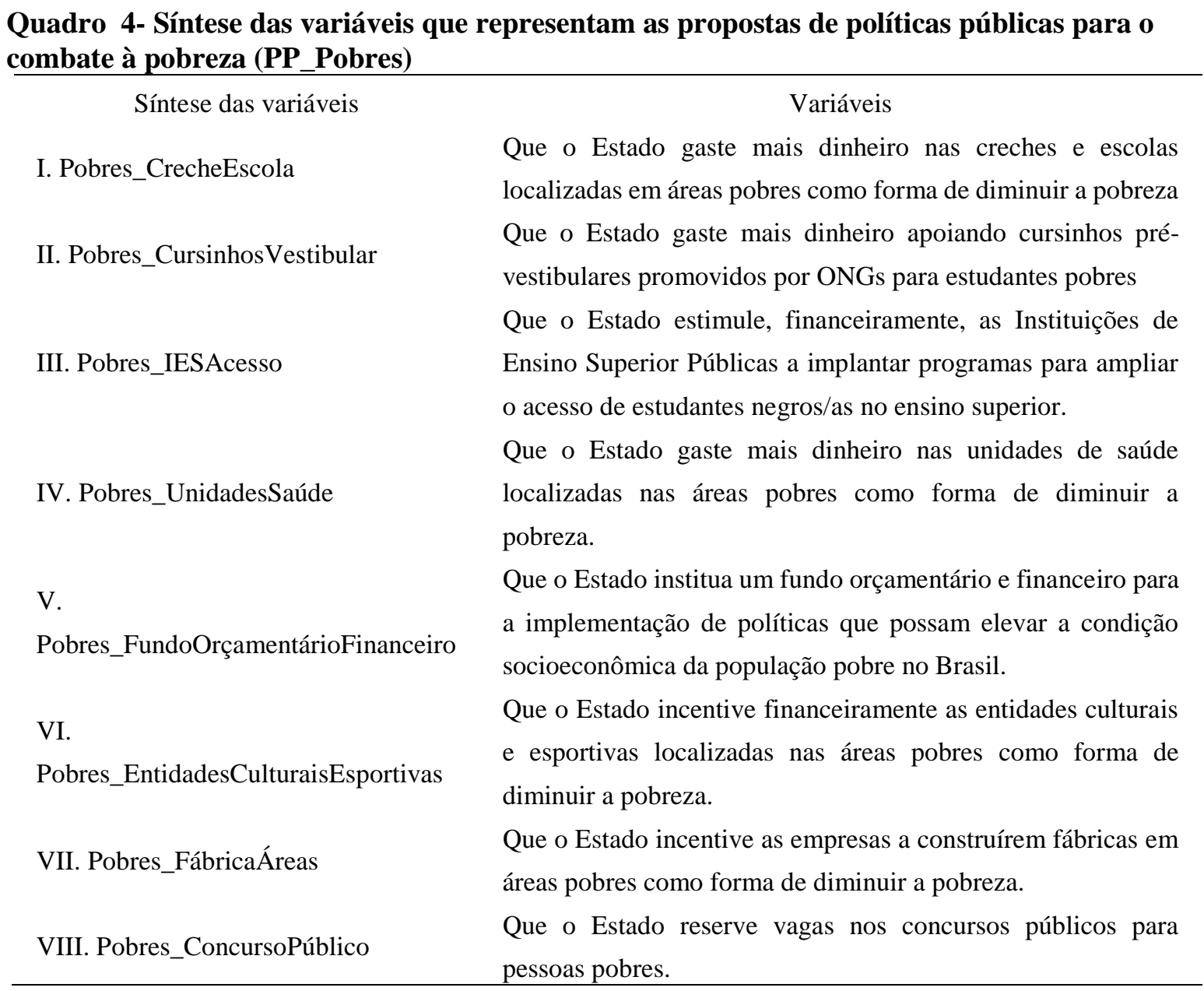

Em relação às variáveis que mensuram a postura dos respondentes quanto às propostas de políticas públicas para a população negra, começamos bem, pois a coerência entre as ideias dos nossos respondentes é grande o que é demonstrado pela alta correlação entre as variáveis. Podemos observar a coerência entre as variáveis que mensuram a opinião dos servidores participantes sobre as políticas públicas voltadas para a população negra. A Tabela 19 apresenta a correlação entre as variáveis com a carga fatorial dessa intercorrelação. Observamos que as variáveis são muito próximas, com uma média de correlação no valor de $\mathrm{r}=0,73$ o que significa dizer que as variáveis estão medindo a mesma coisa. 
Tabela 19 - Matriz de correlação entre as variáveis de propostas de políticas públicas para a população negra (PP_Negros)

\begin{tabular}{|c|c|c|c|c|c|c|c|c|c|}
\hline Variáveis & I & II & III & IV & $\mathrm{V}$ & VI & VII & VIII & $\begin{array}{c}\text { Cargas } \\
\text { no } \\
\text { Fator }\end{array}$ \\
\hline I. Negros_CrecheEscola & - & ,69 &, 75 &, 87 & ,66 &, 78 & ,66 &, 59 & ,90 \\
\hline II. Negros_CursinhosVestibular & ,69 & - &, 70 &, 71 & ,66 & 69 & ,63 &, 57 &, 51 \\
\hline III. Negros_IESAcesso &, 75 &, 70 & - & 80 &, 73 & ,79 & ,69 &, 62 &, 58 \\
\hline IV. Negros_UnidadesSaúde &, 87 &, 71 & 80 & - &, 71 & 83 &, 72 & 60 & 81 \\
\hline V. Negros_FundoOrçamentárioFinanceiro & ,66 & 66 &, 73 &, 71 & - &, 75 & ,69 &, 54 &, 86 \\
\hline VI. Negros_EntidadesCulturaisEsportivas & ,78 & ,69 &, 79 & 83 &, 75 & - &, 73 &, 58 &, 55 \\
\hline VII. Negros_FábricaÁreas & ,66 & ,63 & ,69 &, 72 & ,69 & ,73 & - &, 52 & ,64 \\
\hline VIII. Negros_ConcursoPúblico &, 59 &, 57 &, 62 &, 61 &, 54 &, 58 &, 52 & - &, 40 \\
\hline
\end{tabular}

Fonte: Dados primários - Elaboração da própria autora, 2014

A média das cargas no fator é de 0,66 . O primeiro fator foi extraído com um eigenvalue de 5,83 , com $73 \%$ de variância comum; o segundo fator, com um eigenvalue ${ }^{76}$ de 0,54 , com somente $7 \%$ de variância comum. Esse segundo fator é o ponto de corte como referência para extração de fatores por meio do gráfico scree plot ${ }^{77}$ (Gráfico 10). Então, uma única dimensão ou fator pode explicar $73 \%$ da variância da posição dos nossos respondentes em relação às questões sobre políticas de promoção da igualdade racial.

\footnotetext{
${ }^{76}$ Valores próprios ou autovalores. Eigenvalues são a soma das de cargas fatoriais ao quadrado para um fator ou raiz latente. Representa a quantia de variância explicada por um fator.

${ }^{77}$ O gráfico scree plot auxilia a análise sobre o número de fatores que caracteriza a estrutura empírica da escala. Observa-se o ponto no qual a curva desacelera, formando um cotovelo, descartam-se então os pontos que ficam lado a lado na linha horizontal como critério para decidir sobre o número de fatores.
} 


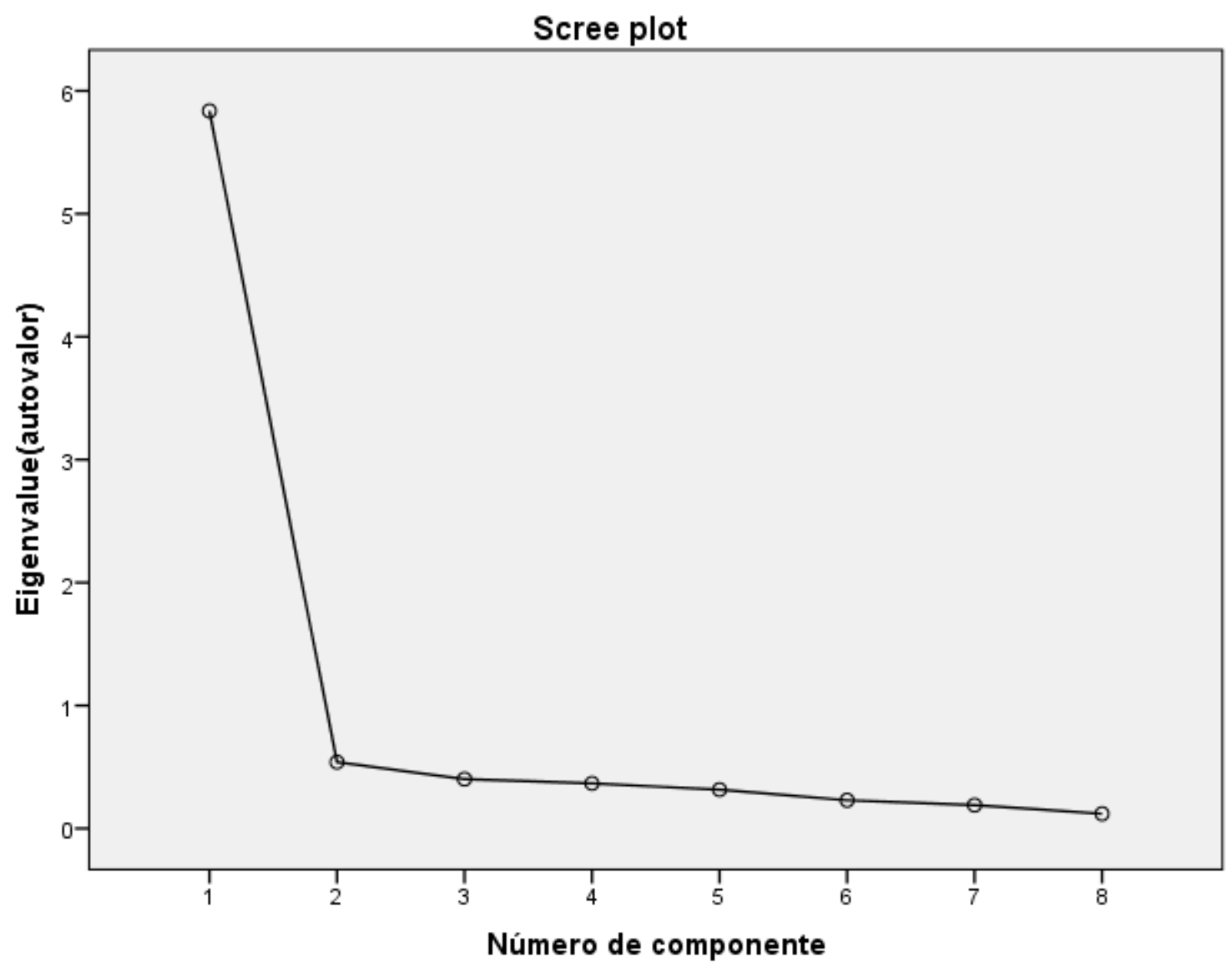

Gráfico 10 - Dimensionamento (Scree plot) das variáveis

O Alfa de Cronbach ${ }^{78}$, que testa a exatidão do conteúdo do fator, é de 0,95 , isso significa que as variáveis que compõem o fator possuem uma alta precisão quanto ao seu conteúdo para serem compartilhadas num único fator. Esses resultados nos dão segurança para trabalhar com um único escore fatorial nas análises posteriores. Conseguimos maximizar o poder de explicação de um único fator para o conjunto das variáveis. Assim uma única variável irá representar as variáveis originais, iremos denominá-la de PP_Negros.

Diferentemente das variáveis que mensuram a dimensão latente sobre o apoio a políticas públicas para a população negra, as questões do escopo de políticas para pobres apresentam baixa correlação (Tabela 20). A média das correlações é de $r=0,37$. Para que pudéssemos realizar a fatoração da matriz é recomendado que essa média ultrapasse o índice de 0,5 Esse índice, portanto, não foi alcançado. Ao analisar uma matriz, 50\% das correlações devem

${ }^{78} 0,8$ é o coeficiente mínimo para dizer se uma consistência é boa (PASQUALI, 2012). 
apresentar coeficientes superiores a 0,3. O índice foi de 28\%. Portanto, não há correlações de tamanho razoável que justifique realizar Análise Fatorial para as variáveis que mensuram políticas para pobres. Outros dados que apoiam a nossa decisão, é o valor do $\mathrm{KMO}=0,79^{79}$ que é um resultado mediano (KAISER, 1974 apud PASQUALI, 2012) ou medíocre como classifica Field (2009), o ideal é que o valor do KMO seja superior a 0,8. Um outro aspecto, é o determinante da matriz, no caso estudado, ele é alto, chegando a 1,80. Esse valor deve ser baixo, mas diferente de zero para indicar a fatorabilidade da matriz ${ }^{80}$.

Tabela 20 - Matriz de correlação entre as variáveis de propostas de políticas públicas de combate à pobreza (PP_Pobres)

\begin{tabular}{lccccccccc}
\hline Variáveis & I & II & III & IV & V & VI & VII & VIII & $\begin{array}{c}\text { Carga } \\
\text { no Fator }\end{array}$ \\
I. Pobres_CrecheEscola & - &, 28 &, 31 &, 65 &, 27 &, 34 &, 22 &, 11 &, 63 \\
II. Pobres_CursinhosVestibular &, 28 & - &, 29 &, 27 &, 28 &, 29 &, 27 &, 15 &, 48 \\
III. Pobres_IESAcesso &, 31 &, 29 & - &, 36 &, 29 &, 28 &, 23 &, 28 &, 53 \\
IV. Pobres_UnidadesSaúde &, 65 &, 27 &, 36 & - &, 32 &, 34 &, 25 &, 15 &, 67 \\
V. Pobres_FundoOrçamentárioFinanceiro &, 27 &, 28 &, 29 &, 32 & - &, 47 &, 40 &, 17 &, 59 \\
VI. Pobres_EntidadesCulturaisEsportivas &, 34 &, 29 &, 28 &, 34 &, 47 & - &, 36 &, 15 &, 61 \\
VII. Pobres_FábricaÁreas &, 22 &, 27 &, 23 &, 25 &, 40 &, 36 & - &, 12 &, 49 \\
VIII. Pobres_ConcursoPúblico &, 11 &, 15 &, 28 &, 15 &, 17 &, 15 &, 12 & - &, $00^{81}$ \\
\hline \multicolumn{1}{c}{ Fonte: Dados primários - Elaboração da própria autora, 2014 } & & & & & & &
\end{tabular}

Fonte: Dados primários - Elaboração da própria autora, 2014

A correlação entre duas variáveis depende do grau de variação na amostra observada. Se todas as outras coisas permanecerem iguais, a redução da variância em uma ou em duas variáveis inevitavelmente reduzirá a sua correlação. Vamos tomar um exemplo dado por Aberbach, Putnam e Rockman (1981) sobre pugilismo. Sabemos que a habilidade de um boxeador está estritamente relacionada com o seu peso. Para reduzir a previsão de quanto maior o peso do boxeador A é em relação ao seu oponente, boxeador B, maior a chance de A levar a melhor frente a B, faz-se necessário limitar a variação da variável independente (o peso) para que não haja nenhuma influência no resultado da luta que não seja a habilidade dos pugilistas. Para isso, as disputas são organizadas somente entre boxeadores da mesma faixa de peso, o que nos levaria à conclusão que o peso não teria nenhuma influência no resultado da luta.

\footnotetext{
${ }^{79}$ KMO é o teste de adequação da amostra de Kaiser-Meyer-Olkin (KMO)

${ }^{80}$ Todos esses indicadores foram considerados para analisar a fatorabilidade da matriz das variáveis sobre políticas públicas para negros que apresentou índices muito bons. $\mathrm{KMO}=0,95$; Determinante $=0,01$

${ }^{81}$ A extração de fatores foi realizada com coeficientes acima de 0,3 .
} 
O que esse exemplo tem a ver com a posição dos nossos respondentes em relação a políticas públicas voltadas aos pobres? A tentativa de realizar a Análise Fatorial com a matriz PP_Pobres nos indica que a nossa população de respondentes é relativamente homogênea sobre as políticas públicas para pobres, pois não há variância que espelhe diferenças e correlações entre as variáveis propostas para a mensuração do seu impacto na pobreza.

A matriz de variáveis que constitui o conceito Função do Estado não foi possível de ser fatorada. Uma indicação de que as variáveis não possuem nenhuma correlação entre elas, não houve colinearidade que favorecesse a fatoração das variáveis de forma a compor um único fator para representar o conceito. Então, optamos em trabalhar com as variáveis que apresentaram significância estatística na correlação com a variável dependente.

A nossa proposta de estudo é realizar análises estatísticas com variáveis dependentes que mensuram a dimensão políticas públicas para a população negra. A exclusão das variáveis relativas à população pobre de forma alguma prejudica a nossa análise. Iremos utilizar as variáveis sobre propostas de políticas públicas para pobres nas nossas análises descritivas com a intenção de exemplificar e entender os dados quantitativos dos respondentes da pesquisa e os argumentos de nossos entrevistados.

\subsection{Operacionalização do modelo}

Para a análise dos dados coletados, trabalhamos as variáveis abaixo de forma a operacionalizar os seus conceitos e as suas possíveis associações. A análise das relações entre variáveis considerou: i) análise univariada: o tratamento de cada variável dependente e independente isoladamente; ii) análise bivariada - a relação entre uma variável dependente e uma variável independente; iii) análise multivariada - as relações entre a variável dependente e as variáveis independentes, isoladamente, e em função das variáveis independentes. As variáveis foram operacionalizadas pelo método de regressão linear múltipla (FIELD, 2009; HAIR et al, 2007), cujos modelos encontram-se na Tabela A7, 
Anexo $\mathrm{A}^{82}$, onde propomos que variáveis de origem social, socialização organizacional e concepções sobre a função do estado influenciam a percepção dos participantes da nossa pesquisa e consequentemente as suas decisões sobre políticas de promoção da igualdade racial (Quadro 5 e Figura 7).

\section{Quadro 5 - Operacionalização das variáveis dependentes e independentes}

Variável Dependente (VD)

Y = Propostas de políticas públicas para a população negra (PP_Negros)

$1=$ Concorda

2 = Não concorda nem discorda

$3=$ Discorda

Variáveis Independentes (VI)

$\mathbf{X}_{1}=$ Nível socioeconômico

Escala com índice entre 16 a 90

$\mathbf{X}_{2}=\operatorname{Sexo}$

$1=$ Feminino

$2=$ Masculino

$\mathbf{X}_{3}=$ Cor/ raça

$1=$ Branco

2 = Não-brancos

$\mathbf{X}_{4}=$ Idade

Ano de nascimento

\section{Socialização Organizacional}

$\mathrm{X}_{5}=$ Tempo de ingresso na carreira

Ano de ingresso na carreira

$\mathrm{X}_{6}=$ Experiência em gestão (Exercício de DAS 2007-2012)

$1=\operatorname{Sim}$

$2=$ Não

$\mathbf{X}_{7}=$ Função do Estado

$1=$ Concorda

2 = Não concorda nem discorda

$3=$ Discorda

\footnotetext{
${ }^{82}$ Equação de Regressão Múltipla: $Y=b_{0}+b_{1} X_{1}+b_{2} X_{2}+\cdots b_{n} X_{n}+\varepsilon$
} 
O modelo teórico é representado no seguinte diagrama.

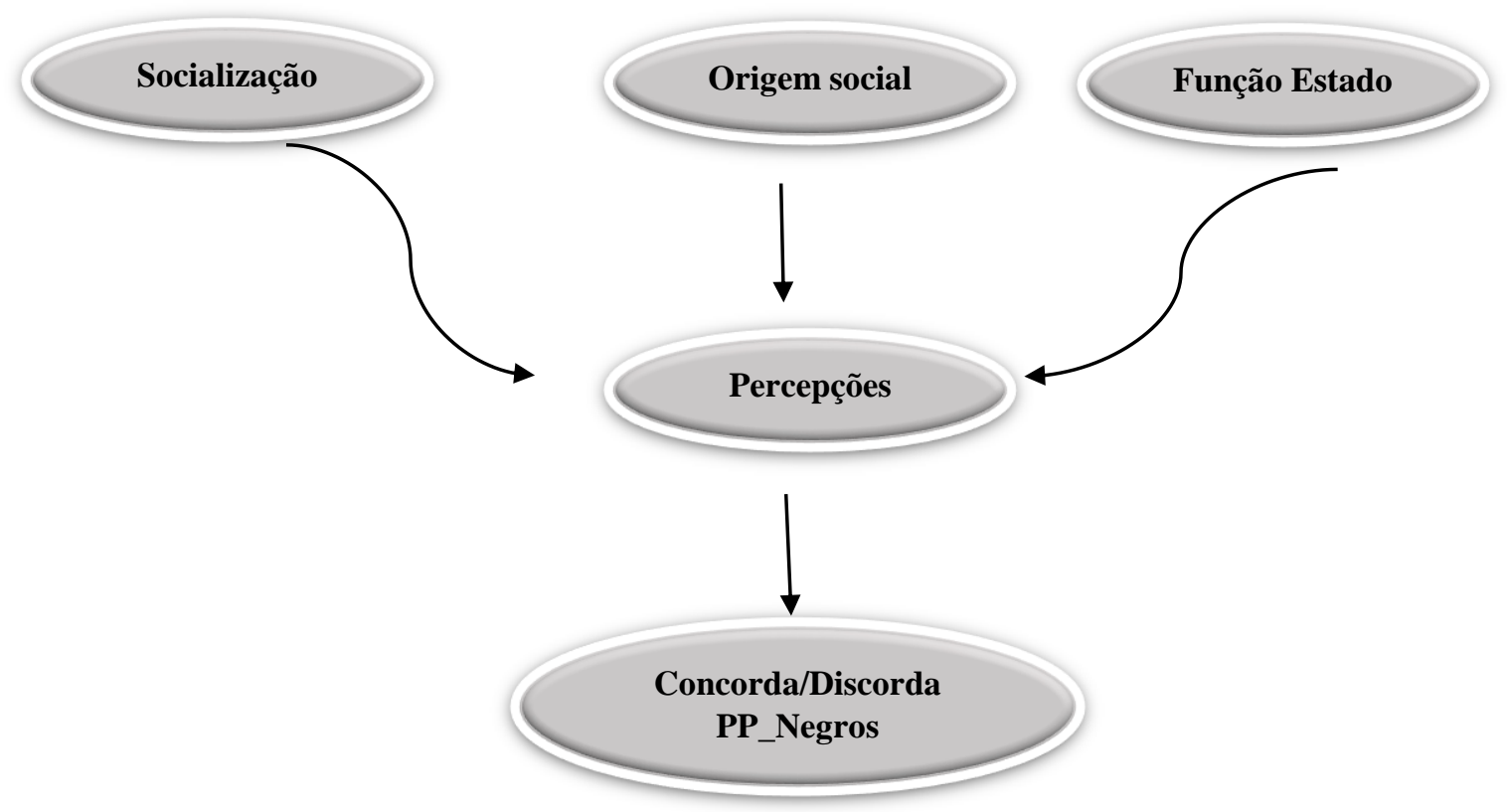

Figura 7 - Modelo proposto

Conforme podem ser analisados os modelos apresentados na Tabela A7, Anexo A, os resultados da análise de regressão múltipla mostraram-se inócuos para alguma direção ou magnitude do relacionamento entre a variável dependente (PP_Negros) e as variáveis de origem social, sendo sexo, cor/raça, nível socioeconômico, idade. Não houve significância estatística $(\mathrm{p}>0,05)$ na análise entre essas variáveis e a variável dependente (PP_Negros). Parte também das variáveis que mensuravam socialização organizacional não apresentou nenhuma relação com a variável dependente. A técnica de regressão múltipla adotada foi a hierárquica ou sequencial conforme representada na Tabela 21. Primeiramente entramos com as variáveis da categoria funções do Estado na equação de regressão múltipla, em seguida com a variável experiência em gestão e assim sequencialmente até fecharmos a equação com o modelo 7 onde é inserida a variável sexo (Tabela 21 e Tabela A7, Anexo A). 
Tabela 21 - Percentual explicado das variáveis independentes em relação às variáveis dependentes

\begin{tabular}{|c|c|c|}
\hline Modelo & $\%$ explic & ada \\
\hline 1 (funções do Estado) & 22,3 & \\
\hline 2 (+ experiência em gestão) & 22,9 & \\
\hline 3 (+ tempo ingresso na carreira)* & 22,9 & \\
\hline 4 (+ índice socioeconômico)* & 22,9 & \\
\hline $5(+ \text { idade })^{*}$ & 22,9 & \\
\hline $6(+ \text { cor e/ou raça })^{*}$ & 22,9 & \\
\hline $7(+ \text { sexo })^{*}$ & 23 & \\
\hline
\end{tabular}

Não foi demonstrado nenhum efeito das variáveis de origem social e de socialização organizacional sobre concordar, discordar ou ter uma postura neutra em relação às políticas de promoção da igualdade racial. Esse resultado contradiz em parte as pesquisas já analisadas $^{83}$ que encontraram alguma relação entre características demográficas e experiência de socialização com variáveis que mensuram atitudes favoráveis de burocratas a ações que beneficiam minorias sociais.

Entretanto, o não efeito das variáveis de origem social e experiência de socialização não significa que não possamos chegar a algumas conclusões sobre os respondentes do questionário. O que não encontramos no teste estatístico foi a associação entre variáveis de origem social e de socialização organizacional em relação à concordância ou discordância quanto a políticas de promoção da igualdade racial.

${ }^{83}$ Meier e Nigro (1976); Thompson (1978); Coleman-Selden (1998); Bradbury e Kellough (2008). 
Tabela 22 - Modelo de regressão para apoio a políticas de promoção da igualdade racial para negros

\begin{tabular}{lccc}
\hline Variáveis Independentes & Coeficientes não padronizados & $\begin{array}{c}\text { Coeficientes } \\
\text { padronizados }\end{array}$ \\
& B & Erro padrão & Beta $(\beta)$ \\
(Constante) & 19,812 & 1,293 & \\
OrdemLeisObedecidas & $-1,049$ &, 203 &,- 165 \\
CapacitadasReconhecidas &,- 700 &, 211 &,- 107 \\
PolíticasIguadadeSocEconômica & 1,245 &, 387 &, 102 \\
ProteçãoaTodos & $-1,677$ &, 264 &,- 203 \\
ProblemaPobresApoioEstado & 1,889 &, 402 &, 147 \\
MercadoVidaSocial &,- 817 &, 267 &,- 099 \\
DemandasCidadãoDemocrático & 1,045 &, 260 &, 123 \\
Experiência em Gestão &, 929 &, 370 &, 077 \\
\hline nte: Dados primários - Elaboração da própria autora & &
\end{tabular}

As variáveis que se mostraram importantes para a predição dos escores da variável dependente (PP_Negros) foram Experiência em Gestão e Função do Estado (Tabela 22). Essas variáveis apresentaram significância estatística $(\mathrm{p}<0,05)$ o que nos diz que existe uma probabilidade de menos de $5 \%$ dos resultados serem apenas um golpe de sorte. Há uma correlação entre a VD e as VIs, $\mathrm{R}=0,48$ (Tabela 22).

De forma geral, as variáveis inclusas nos modelo 1 e modelo 2 explicam $23 \%$ da variabilidade dos escores da VD (Tabela 21 e Tabela A7, Anexo A). Sob o ponto de vista da teoria da representação burocrática, o percentual predito é semelhante ao encontrado nos estudos aqui já referenciados. Coleman-Selden (1998) desenvolveu e testou um modelo estatístico em que analisa fatores que levam o gestor público a ter uma atitude de representação de minorias sociais, os $\mathrm{R}^{2}$ encontrados foram 0,19 ; passando por 0,31 e 0,5 conforme a relação das VIs e VDs na equação com níveis de significância entre 0,001 a 0,05. Brudney, Hebert e Wright (2000) nos seus estudos encontrou $\mathrm{R}^{2}$ entre 0,027 a 0,064 em diferentes níveis de significância estatística. Meier e Nigro (1976) demonstraram baixos coeficientes de $\mathrm{R}^{2}$, entre 0,15 a 0,32 com $\mathrm{p}<0,05$.

Os resultados encontrados nos afirmam que há uma influência do tempo de experiência em gestão na administração pública sobre a percepção dos participantes em relação às políticas 
de promoção da igualdade racial. Assim como, há uma relação de como aqueles que responderam a nossa pesquisa pensam sobre a função do Estado e a sua posição sobre as políticas específicas para a população negra. Vejamos, a maioria dos respondentes que tem uma opinião que o Estado deve manter a ordem e fazer cumprir a lei independentemente de ser injusta tem uma tendência em não apoiar as políticas públicas propostas para a população negra (Tabela 23).

Tabela 23 - Cruzamento entre a função do Estado OrdemLeisObedecidas e políticas de promoção da igualdade racial $(\%)$

\begin{tabular}{|c|c|c|c|c|}
\hline & & \multicolumn{3}{|c|}{ OrdemLeisObedecidas } \\
\hline & & Concorda & $\begin{array}{l}\text { Não concorda } \\
\text { nem discorda }\end{array}$ & Discorda \\
\hline \multirow{3}{*}{ Negros_CrecheEscola } & Concorda & 25,9 & 36,7 & 47,8 \\
\hline & Não concorda nem discorda & 14,8 & 17,7 & 13,5 \\
\hline & Discorda & 59,3 & 45,6 & 38,7 \\
\hline \multirow{3}{*}{ Negros_CursinhosVestibular } & Concorda & 16,2 & 27,8 & 37,3 \\
\hline & Não concorda nem discorda & 15,5 & 16,5 & 14,6 \\
\hline & Discorda & 68,3 & 55,7 & 48,1 \\
\hline \multirow{3}{*}{ Negros_IESAcesso } & Concorda & 29,5 & 35,4 & 51,1 \\
\hline & Não concorda nem discorda & 10,2 & 19,0 & 8,6 \\
\hline & Discorda & 60,3 & 45,6 & 40,3 \\
\hline \multirow{3}{*}{ Negros_UnidadesSaúde } & Concorda & 21,8 & 34,2 & 44,8 \\
\hline & Não concorda nem discorda & 13,1 & 17,7 & 12,2 \\
\hline & Discorda & 65,1 & 48,1 & 43,1 \\
\hline \multirow{3}{*}{ Negros_FábricaÁreas } & Concorda & 14,8 & 19,0 & 29,6 \\
\hline & Não concorda nem discorda & 17,7 & 25,3 & 21,8 \\
\hline & Discorda & 67,6 & 55,7 & 48,6 \\
\hline \multirow{3}{*}{ Negros_ConcursoPúblico } & Concorda & 10,2 & 25,3 & 30,7 \\
\hline & Não concorda nem discorda & 8,5 & 11,4 & 9,4 \\
\hline & Discorda & 81,4 & 63,3 & 59,9 \\
\hline
\end{tabular}

Fonte: Dados primários - Elaboração da própria autora, 2014 
A mesma tendência apresentaram aqueles que acreditam que o Estado deve garantir o reconhecimento social e econômico a pessoas mais capacitadas em relação àquelas menos capazes (Tabela 24).

Tabela 24 - Cruzamento entre a função do Estado CapacitadasReconhecidas e políticas de promoção da igualdade racial $(\%)$

\begin{tabular}{|c|c|c|c|c|}
\hline & & \multicolumn{3}{|c|}{ CapacitadasReconhecidas } \\
\hline & & Concorda & $\begin{array}{l}\text { Não concorda } \\
\text { nem discorda }\end{array}$ & Discorda \\
\hline \multirow{3}{*}{ Negros_CrecheEscola } & Concorda & 23,3 & 36,8 & 45,5 \\
\hline & Não concorda nem discorda & 14,4 & 24,8 & 11,8 \\
\hline & Discorda & 62,3 & 38,5 & 42,7 \\
\hline \multirow{3}{*}{ Negros_CursinhosVestibular } & Concorda & 15,3 & 30,8 & 33,0 \\
\hline & Não concorda nem discorda & 14,7 & 23,1 & 13,4 \\
\hline & Discorda & 70,0 & 46,2 & 53,5 \\
\hline \multirow{3}{*}{ Negros_IESAcesso } & Concorda & 24,6 & 45,3 & 48,3 \\
\hline & Não concorda nem discorda & 9,9 & 13,7 & 9,7 \\
\hline & Discorda & 65,5 & 41,0 & 42,0 \\
\hline \multirow{3}{*}{ Negros_UnidadesSaúde } & Concorda & 20,4 & 34,2 & 41,3 \\
\hline & Não concorda nem discorda & 13,4 & 21,4 & 10,6 \\
\hline & Discorda & 66,1 & 44,4 & 48,1 \\
\hline \multirow{3}{*}{ Negros_FábricaÁreas } & Concorda & 16,0 & 17,1 & 26,7 \\
\hline & Não concorda nem discorda & 14,1 & 29,9 & 21,9 \\
\hline & Discorda & 70,0 & 53,0 & 51,4 \\
\hline \multirow{3}{*}{ Negros_ConcursoPúblico } & Concorda & 10,9 & 24,8 & 25,9 \\
\hline & Não concorda nem discorda & 4,2 & 17,1 & 10,6 \\
\hline & Discorda & 85,0 & 58,1 & 63,4 \\
\hline
\end{tabular}


Também, nessa mesma direção, a maioria que não concorda com políticas voltadas para a população negra está entre aqueles que defendem que o Estado proteja a todos sem distinção socioeconômica, pois assim não irá prejudicar quem venceu pelo próprio esforço (Tabela 25).

Tabela 25 - Cruzamento entre a função do Estado ProteçãoaTodos e políticas de promoção da igualdade racial (\%)

\begin{tabular}{|c|c|c|c|c|}
\hline & & \multicolumn{3}{|c|}{ ProteçãoaTodos } \\
\hline & & Concorda & $\begin{array}{l}\text { Não concorda } \\
\text { nem discorda }\end{array}$ & Discorda \\
\hline \multirow{3}{*}{ Negros_CrecheEscola } & Concorda & 29,5 & 59,6 & 60,5 \\
\hline & Não concorda nem discorda & 14,8 & 17,5 & 11,6 \\
\hline & Discorda & 55,7 & 22,8 & 27,9 \\
\hline \multirow{3}{*}{ Negros_CursinhosVestibular } & Concorda & 20,2 & 45,6 & 48,8 \\
\hline & Não concorda nem discorda & 15,4 & 21,1 & 11,6 \\
\hline & Discorda & 64,4 & 33,3 & 39,5 \\
\hline \multirow{3}{*}{ Negros_IESAcesso } & Concorda & 32,5 & 66,7 & 62,0 \\
\hline & Não concorda nem discorda & 10,2 & 14,0 & 9,3 \\
\hline & Discorda & 57,3 & 19,3 & 28,7 \\
\hline \multirow{3}{*}{ Negros_UnidadesSaúde } & Concorda & 26,0 & 52,6 & 58,1 \\
\hline & Não concorda nem discorda & 12,7 & 24,6 & 10,1 \\
\hline & Discorda & 61,2 & 22,8 & 31,8 \\
\hline \multirow{3}{*}{ Negros_FábricaÁreas } & Concorda & 17,1 & 31,6 & 39,5 \\
\hline & Não concorda nem discorda & 18,0 & 31,6 & 26,4 \\
\hline & Discorda & 65,0 & 36,8 & 34,1 \\
\hline \multirow{3}{*}{ Negros_ConcursoPúblico } & Concorda & 14,7 & 35,1 & 42,6 \\
\hline & Não concorda nem discorda & 7,8 & 24,6 & 9,3 \\
\hline & Discorda & 77,5 & 40,4 & 48,1 \\
\hline
\end{tabular}


Um último dado dessa magnitude, ou seja, a discordância quanto a propostas de políticas públicas que beneficiam a população negra, vem da maioria que acredita que o Estado deva dar o espaço para o mercado coordenar a vida social (Tabela 26).

Tabela 26 - Cruzamento entre a função do Estado MercadoVidaSocial e políticas de promoção da igualdade racial $(\%)$

\begin{tabular}{|c|c|c|c|c|}
\hline & & \multicolumn{3}{|c|}{ MercadoVidaSocial } \\
\hline & & Concorda & $\begin{array}{l}\text { Não concorda } \\
\text { nem discorda }\end{array}$ & Discorda \\
\hline \multirow{3}{*}{ Negros_CrecheEscola } & Concorda & 19,7 & 22,7 & 42,4 \\
\hline & Não concorda nem discorda & 11,5 & 22,7 & 13,4 \\
\hline & Discorda & 68,9 & 54,7 & 44,2 \\
\hline \multirow{3}{*}{ Negros_CursinhosVestibular } & Concorda & 9,8 & 14,1 & 32,1 \\
\hline & Não concorda nem discorda & 12,3 & 18,8 & 15,1 \\
\hline & Discorda & 77,9 & 67,2 & 52,8 \\
\hline \multirow{3}{*}{ Negros_IESAcesso } & Concorda & 19,7 & 23,4 & 46,5 \\
\hline & Não concorda nem discorda & 7,4 & 15,6 & 9,8 \\
\hline & Discorda & 73,0 & 60,9 & 43,7 \\
\hline \multirow{3}{*}{ Negros_UnidadesSaúde } & Concorda & 19,7 & 21,1 & 37,7 \\
\hline & Não concorda nem discorda & 9,8 & 17,2 & 12,9 \\
\hline & Discorda & 70,5 & 61,7 & 49,3 \\
\hline \multirow{3}{*}{ Negros_FábricaÁreas } & Concorda & 18,0 & 11,7 & 24,2 \\
\hline & Não concorda nem discorda & 8,2 & 18,8 & 22,8 \\
\hline & Discorda & 73,8 & 69,5 & 53,0 \\
\hline \multirow{3}{*}{ Negros_ConcursoPúblico } & Concorda & 7,4 & 10,9 & 24,8 \\
\hline & Não concorda nem discorda & 4,9 & 12,5 & 9,3 \\
\hline & Discorda & 87,7 & 76,6 & 65,9 \\
\hline
\end{tabular}


Numa outra vertente, a maioria das pessoas com tendências a apoiar políticas para a população negra concordou que a função do Estado deve ser implementar políticas públicas para prover a igualdade social e econômica (Tabela 27).

Tabela 27 - Cruzamento entre a função do Estado PolíticasIgualdadeSocEconômica e políticas de promoção da igualdade racial (\%)

\begin{tabular}{|c|c|c|c|c|}
\hline & & \multicolumn{3}{|c|}{ PolíticasIguadadeSocEconômica } \\
\hline & & Concorda & $\begin{array}{l}\text { Não concorda } \\
\text { nem discorda }\end{array}$ & Discorda \\
\hline \multirow{3}{*}{ Negros_CrecheEscola } & Concorda & 38,5 & 10,0 & 16,0 \\
\hline & Não concorda nem discorda & 15,1 & 13,3 & 6,0 \\
\hline & Discorda & 46,4 & 76,7 & 78,0 \\
\hline \multirow{3}{*}{ Negros_CursinhosVestibular } & Concorda & 28,2 & 6,7 & 8,0 \\
\hline & Não concorda nem discorda & 15,9 & 13,3 & 6,0 \\
\hline & Discorda & 55,9 & 80,0 & 86,0 \\
\hline \multirow{3}{*}{ Negros_IESAcesso } & Concorda & 41,9 & 10,0 & 16,0 \\
\hline & Não concorda nem discorda & 10,3 & 13,3 & 8,0 \\
\hline & Discorda & 47,8 & 76,7 & 76,0 \\
\hline \multirow{3}{*}{ Negros_UnidadesSaúde } & Concorda & 34,6 & 6,7 & 18,0 \\
\hline & Não concorda nem discorda & 13,6 & 16,7 & 4,0 \\
\hline & Discorda & 51,8 & 76,7 & 78,0 \\
\hline \multirow{3}{*}{ Negros_FábricaÁreas } & Concorda & 22,5 & 3,3 & 16,0 \\
\hline & Não concorda nem discorda & 21,2 & 10,0 & 10,0 \\
\hline & Discorda & 56,3 & 86,7 & 74,0 \\
\hline \multirow{3}{*}{ Negros_ConcursoPúblico } & Concorda & 21,8 & 6,7 & 4,0 \\
\hline & Não concorda nem discorda & 9,9 &, 0 & 2,0 \\
\hline & Discorda & 68,2 & 93,3 & 94,0 \\
\hline
\end{tabular}


Da mesma forma, a maioria dos respondentes que veem que o problema dos mais pobres será resolvido pelo Estado também são favoráveis às propostas de políticas pública voltadas aos negros. Isso nos traz um indício da relação que se faz entre pobreza e negritude que discutiremos mais à frente tomando como base as entrevistas realizadas (Tabela 28).

Tabela 28 - Cruzamento entre a função do Estado ProblemaPobresApoioEstado e políticas de promoção da igualdade racial $(\%)$

\begin{tabular}{|c|c|c|c|c|}
\hline & & \multicolumn{3}{|c|}{ ProblemaPobresApoioEstado } \\
\hline & & Concorda & $\begin{array}{l}\text { Não concorda } \\
\text { nem discorda }\end{array}$ & Discorda \\
\hline \multirow{3}{*}{ Negros_CrecheEscola } & Concorda & 38,7 & 11,3 & 20,5 \\
\hline & Não concorda nem discorda & 14,3 & 17,0 & 15,4 \\
\hline & Discorda & 47,0 & 71,7 & 64,1 \\
\hline \multirow{3}{*}{ Negros_CursinhosVestibular } & Concorda & 28,5 & 7,5 & 7,7 \\
\hline & Não concorda nem discorda & 15,7 & 11,3 & 10,3 \\
\hline & Discorda & 55,8 & 81,1 & 82,1 \\
\hline \multirow{3}{*}{ Negros_IESAcesso } & Concorda & 42,5 & 13,2 & 10,3 \\
\hline & Não concorda nem discorda & 10,9 & 9,4 &, 0 \\
\hline & Discorda & 46,6 & 77,4 & 89,7 \\
\hline \multirow{3}{*}{ Negros_UnidadesSaúde } & Concorda & 35,3 & 9,4 & 12,8 \\
\hline & Não concorda nem discorda & 13,8 & 13,2 &, 0 \\
\hline & Discorda & 50,9 & 77,4 & 87,2 \\
\hline \multirow{3}{*}{ Negros_FábricaÁreas } & Concorda & 23,4 & 5,7 & 5,1 \\
\hline & Não concorda nem discorda & 21,7 & 11,3 & 2,6 \\
\hline & Discorda & 55,0 & 83,0 & 92,3 \\
\hline \multirow{3}{*}{ Negros_ConcursoPúblico } & Concorda & 22,4 & 1,9 & 2,6 \\
\hline & Não concorda nem discorda & 9,8 & 3,8 & 2,6 \\
\hline & Discorda & 67,7 & 94,3 & 94,9 \\
\hline
\end{tabular}


Finalmente, a maioria que defende que o Estado deve atender às demandas dos cidadãos também apoia políticas de promoção da igualdade racial para a população negra (Tabela 29)

Tabela 29 - Cruzamento entre a função do Estado DemandasCidadãoDemocrático e políticas de promoção da igualdade racial $(\%)$

\begin{tabular}{|c|c|c|c|c|}
\hline & & \multicolumn{3}{|c|}{ DemandasCidadãoDemocrático } \\
\hline & & Concorda & $\begin{array}{l}\text { Não concorda } \\
\text { nem discorda }\end{array}$ & Discorda \\
\hline \multirow{3}{*}{ Negros_CrecheEscola } & Concorda & 42,4 & 26,1 & 20,0 \\
\hline & Não concorda nem discorda & 12,9 & 24,4 & 7,3 \\
\hline & Discorda & 44,7 & 49,4 & 72,7 \\
\hline \multirow{3}{*}{ Negros_CursinhosVestibular } & Concorda & 29,9 & 18,2 & 20,0 \\
\hline & Não concorda nem discorda & 15,3 & 21,0 & 5,5 \\
\hline & Discorda & 54,8 & 60,8 & 74,5 \\
\hline \multirow{3}{*}{ Negros_IESAcesso } & Concorda & 43,5 & 32,4 & 28,2 \\
\hline & Não concorda nem discorda & 9,5 & 15,9 & 5,5 \\
\hline & Discorda & 47,0 & 51,7 & 66,4 \\
\hline \multirow{3}{*}{ Negros_UnidadesSaúde } & Concorda & 38,2 & 22,2 & 20,9 \\
\hline & Não concorda nem discorda & 12,3 & 19,3 & 7,3 \\
\hline & Discorda & 49,5 & 58,5 & 71,8 \\
\hline \multirow{3}{*}{ Negros_FábricaÁreas } & Concorda & 25,9 & 13,6 & 10,9 \\
\hline & Não concorda nem discorda & 20,1 & 27,3 & 9,1 \\
\hline & Discorda & 54,0 & 59,1 & 80,0 \\
\hline \multirow{3}{*}{ Negros_ConcursoPúblico } & Concorda & 23,8 & 13,6 & 12,7 \\
\hline & Não concorda nem discorda & 10,2 & 10,2 & 1,8 \\
\hline & Discorda & 66,0 & 76,1 & 85,5 \\
\hline
\end{tabular}

Em relação à experiência em gestão, outro fator associado à aprovação de políticas públicas que beneficiam a população negra, perguntamos se os respondentes tinham exercido cargo em comissão no período de 2007 a 2012; 55\% responderam que sim, desses, 23\% ocuparam DAS igual ou acima do nível 4. O que nos leva a especular se exercer funções de natureza que exigem liderança, gestão de pessoas, articulação política e decisão de nível de alta complexidade proporcionaria um outro tipo de socialização a ponto de terem levado os nossos respondentes a concordarem com as políticas propostas para a população negra. Vemos pela Tabela 30 que há uma tendência entre aqueles que possuíam experiência em gestão terem uma postura mais de acordo com as propostas que favorecem a população negra. 


\begin{tabular}{llcc}
\hline & & \multicolumn{2}{l}{ Experiência em Gestão } \\
& & Não & Sim \\
& & & \\
\multirow{2}{*}{ Negros_CrecheEscola } & Noncorda & 33,9 & 38,1 \\
& Não concorda nem discorda & 11,5 & 17,0 \\
& Discorda & 54,7 & 44,9 \\
& Concorda & 24,2 & 27,9 \\
Negros_CursinhosVestibular & Não concorda nem discorda & 13,3 & 16,8 \\
& Discorda & 62,5 & 55,3 \\
& & & \\
\multirow{2}{*}{ Negros_IESAcesso } & Concorda & 33,6 & 43,8 \\
& Não concorda nem discorda & 8,6 & 11,7 \\
& Discorda & 57,8 & 44,5 \\
Negros_UnidadesSaúde & & & \\
& Concorda & 30,2 & 34,7 \\
& Não concorda nem discorda & 9,1 & 16,4 \\
& Discorda & 60,7 & 48,9 \\
Negros_FábricaÁreas & Concorda & 20,6 & 22,1 \\
& Não concorda nem discorda & 15,4 & 24,0 \\
& Discorda & 64,1 & 53,8 \\
& & & \\
Negros_ConcursoPúblico & Concorda & 17,4 & 22,6 \\
& Não concorda nem discorda & 8,9 & 9,4 \\
& Discorda & 73,7 & 68,1 \\
\hline
\end{tabular}

Fonte: Dados primários - Elaboração da própria autora, 2014

Voltando ao teste estatístico, há uma variação de $77 \%$ da variável dependente que não é mensurada pelas variáveis independentes propostas no modelo. As demais variáveis demográficas, sexo, cor/raça, idade, nível econômico, não deram conta de explicar a variância da VD totalmente. Há outros fatores que levaram os nossos respondentes a se posicionarem em relação a propostas de políticas de promoção da igualdade racial para a população negra. Não alcançamos a associação desses outros fatores com a VD na nossa pesquisa. Aspectos que poderão ser explorados em trabalhos futuros.

Este estudo não mensurou, entre os servidores que participaram da pesquisa, a convicção sobre a existência de racismo no Brasil e, consequentemente, de como isso poderia influenciar na tomada de decisão sobre políticas públicas, bem como sobre a existência da ideia de democracia racial e como ela opera no cotidiano da administração pública. Dificilmente as pessoas falariam abertamente sobre questões tão diretas como racismo, se são ou não racistas e o que pensam sobre a democracia racial. A tendência seria responder 
ao questionário com a intenção de acertar a resposta. Teríamos então um desafio de elaborar perguntas que não levassem a respostas socialmente aceitáveis e, por outro lado, estamos cientes de que qualquer pesquisa possui algum nível de desejabilidade social. No que tange a esse desafio, a forma como optamos pelo desenho da pesquisa não nos permitiria explorar a percepção de nossos participantes sobre racismo.

Schucman (2014) relata com surpresa o seu sucesso em tratar temas como esses de forma direta em suas entrevistas. A autora conversou com pessoas brancas sobre ser branco, sobre raça e se haviam sido protagonistas de alguma atitude racista. A pesquisadora imputa que a facilidade com que as pessoas entrevistadas responderam a suas perguntas se deveu ao fato delas serem brancas, da própria pesquisadora no contexto social brasileiro ser considerada branca e da maioria dos sujeitos entrevistados a conhecerem. Esses aspectos levaram os seus entrevistados a sentirem-se à vontade sobre conteúdos racistas e sobre a superioridade racial dos brancos no que se refere a padrões estéticos e morais. Schucman (2014) argumenta que o fato dela ser branca fez com que os entrevistados não sentissem que um gesto racial fosse interpretado por ela como uma ofensa pessoal.

No nosso caso, o desenho da pesquisa, na primeira fase, baseado em questionário aplicado on-line, se por um lado tornava a nossa a identificação racial invisível, afastava a possibilidade de interação e de explorar as questões. Nas entrevistas presenciais a nossa identificação como negra poderia trazer algum desconforto para que os nossos entrevistados tratassem da questão do racismo tão diretamente. Entretanto, acreditamos que temas como racismo e a ideologia da democracia racial no Brasil, se explorados, poderiam nos dar outras evidências sobre como pensa parte da alta administração pública e o seu impacto na formulação e implementação de políticas públicas.

\subsection{Conclusões Preliminares}

Identificamos que há uma relação entre o que pensa a burocracia sobre o papel do Estado as políticas de promoção da igualdade racial para a população negra. O que significa dizer que uma determinada forma de pensar o papel do Estado influenciou os servidores participantes a se posicionarem de maneira favorável ou desfavorável às propostas de políticas públicas 
para a população negra. Outra variável com a mesma dimensão foi o tempo de experiência em gestão. Da mesma forma, o tempo de experiência em gestão influencia de alguma maneira a percepção do servidor quanto a concordar ou discordar de políticas de promoção da igualdade racial.

O nosso propósito foi testar as variáveis da teoria da representação burocrática no contexto nacional. Longe de argumentar que a burocracia que respondeu ao questionário e que foi entrevistada pode ser generalizada, mas os dados nos indicam alguma tendência a ser investigada em estudos com amostras aleatórias e de vertentes qualitativas. Em razão da delimitação da nossa pesquisa, dificilmente podemos especificar o quanto da experiência em gestão leva o nosso respondente a tender de forma mais favorável ou menos favorável a políticas de promoção da igualdade racial. Da mesma forma, as funções do Estado. Se estar de acordo com determinada atuação estatal direciona a percepção dos respondentes quanto a concordar ou discordar de ações para a população negra.

Por outro lado, o modelo proposto pela teoria da burocracia representativa nos sugere que não há entre as carreiras entrevistadas neste estudo uma representação passiva da população negra. Chegamos à mesma conclusão quanto a uma possível representação ativa ao analisar a tendência das respostas dos nossos participantes quando inqueridos sobre determinadas proposições de políticas de promoção da igualdade racial. Daremos uma qualificação para as respostas aqui apresentadas no próximo capítulo onde poderemos analisar o que poderia fundamentar a posição dos nossos participantes. 


\title{
Capítulo 6 - O que disseram os nossos entrevistados
}

\begin{abstract}
No início da década de 1960, o novo quadro das relações raciais no Brasil não correspondia exatamente às expectativas de seus patrocinadores da UNESCO. Cientistas sociais do Brasil e do exterior empregaram as mais modernas técnicas de pesquisa para traçar uma complexa rede de correlações entre cor e posição social. Embora os dados não fossem muito abrangentes, e ainda que existissem algumas variações regionais significativas e as opiniões dos pesquisadores divergissem a respeito de como a cor influencia a mobilidade social no futuro, tornava-se evidente que quanto mais escura fosse a pele de um brasileiro, mais probabilidades ele teria de estar no limite inferior da escala socioeconômica, e isso de acordo com todos os indicadores renda, ocupação, educação. Os jornalistas não tardaram em aderir, dando provas circunstanciais de um modelo de discriminação sutil mas indisfarçável nas relações sociais. Já não era possível afirmar que o Brasil escapara da discriminação racial, embora ela nunca tenha sido oficializada, desde o período colonial. $O$ peso cada vez maior das evidências demonstrava justamente o contrário, mesmo sendo um tipo de discriminação muito mais complexo do que o existente na sociedade birracial americana.
\end{abstract}

Thomas SKIDMORE (2012:296)

Além dos dados quantitativos, vamos analisar o que disseram os nossos entrevistados para qualificar os resultados apresentados no capítulo anterior. Primeiramente, tomamos os dados quantitativos de forma a demonstrar as tendências daqueles que responderam ao questionário on-line e em seguida analisamos as entrevistas com a intenção de identificar o que poderia significar as concordâncias ou discordâncias a nossas questões. Finalmente, discutiremos o potencial dessa burocracia na representação ativa da população negra.

Perguntamos aos nossos entrevistados o quão de acordo eles estavam com algumas propostas de políticas públicas para pobres e negros. As questões compreendiam respostas dentro de uma escala de 1 a 5, com as seguintes categorias: 1. Concorda muito; 2. Concorda; 3. Não concorda, nem discorda; 4. Discorda; 5. Discorda muito. Para a parcimônia da análise, reduzimos a escala para 1. Concorda; 2. Não concorda, nem discorda; 3. Discorda. Podemos observar que há uma maior discordância nas questões que se referem a políticas de promoção da igualdade racial para a população negra, diferentemente para as propostas voltadas para 
o combate à pobreza. Percebemos essa tendência pelo valor da Moda na Tabela 31, os valores mais frequentes no caso das políticas para pobres é o Concorda (1), já para os negros é Discorda (3).

Tabela 31 - Estatísticas descritivas de políticas públicas para negros e pobres

\begin{tabular}{lccccc}
\hline & \multicolumn{2}{c}{ Erro de } & & \\
& Média & média & Mediana & Moda & Variância \\
& & padrão & & & \\
& 2,13 & 0,031 & 2,00 & 3 & 0,83 \\
Negros_CrecheEscola & 1,07 & 0,012 & 1,00 & 1 & 0,11 \\
Pobres_CrecheEscola & 2,32 & 0,030 & 3,00 & 3 & 0,74 \\
Negros_CursinhosVestibular & 1,47 & 0,028 & 1,00 & 1 & 0,64 \\
Pobres_CursinhosVestibular & 2,11 & 0,032 & 3,00 & 3 & 0,88 \\
Negros_IESAcesso & 1,23 & 0,021 & 1,00 & 1 & 0,37 \\
Pobres_IESAcesso & 2,22 & 0,031 & 3,00 & 3 & 0,82 \\
Negros_UnidadesSaúde & 1,09 & 0,014 & 1,00 & 1 & 0,15 \\
Pobres_UnidadesSaúde & 2,23 & 0,030 & 3,00 & 3 & 0,79 \\
Negros_FundoOrçamentárioFinanceiro & 1,28 & 0,22 & 1,00 & 1 & 0,40 \\
Pobres_FundoOrçamentárioFinanceiro & 2,14 & 0,032 & 3,00 & 3 & 0,85 \\
Negros_EntidadesCulturaisEsportivas & 1,16 & 0,017 & 1,00 & 1 & 0,24 \\
Pobres_EntidadesCulturaisEsportivas & 2,37 & 0,028 & 3,00 & 3 & 0,66 \\
Negros_FábricaÁreas & 1,38 & 0,024 & 1,00 & 1 & 0,49 \\
Pobres_FábricaÁreas & 2,50 & 0,028 & 3,00 & 3 & 0,65 \\
Negros_ConcursoPúblico & 2,25 & 0,032 & 3,00 & 3 & 0,85 \\
Pobres_ConcursoPúblico & & & & \\
\hline
\end{tabular}

Fonte: Dados primário - Elaboração da própria autora, 2014

$\mathrm{N}=854$, todas as questões foram respondidas pelos participantes.

A Tabela 32 confirma a tendência dos nossos respondentes em ter uma opinião mais favorável em relação a propostas de políticas para pobres do que para negros. Os percentuais da categoria Não concorda nem discorda diferem entre políticas para pobres e políticas para negros. 
Tabela 32 - Percentual de pessoas que concordam ou não com propostas de políticas públicas para negros e pobres

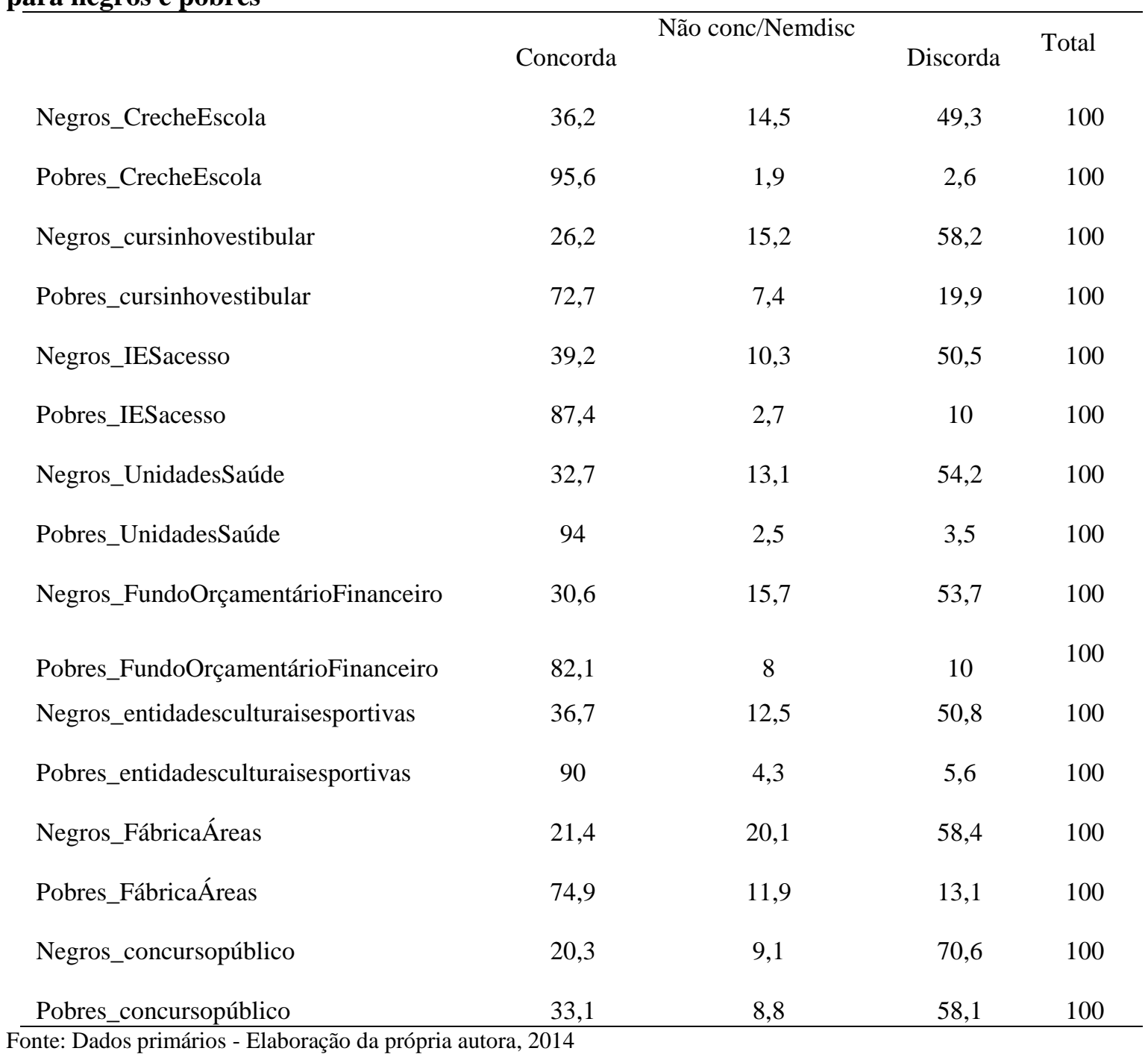

A título de exemplificação dos resultados da Tabela 32, tomamos algumas questões para observarmos a frequência percentual de resposta dos participantes. Nas entrevistas questionamos sobre propostas de creches para população negra; reserva de vagas em concursos públicos para negros; cursinhos pré-vestibulares para estudantes negros; priorização em construir fábricas em áreas pobres como forma de diminuir a pobreza; estímulo financeiro para que as Instituições de Ensino Superior Públicas ampliem o acesso de estudantes pobres no ensino superior; priorização em construir unidades de saúde em áreas pobres como forma de diminuir a pobreza. Vamos focar a nossa análise estatística nestas variáveis de forma a qualificar os argumentos das entrevistas. 
Vemos que na Tabela 32, entre outros aspectos, quando se trata de vagas em concursos públicos para negros e pobres, a posição dos respondentes é muito próxima comparativamente a outras questões, $70 \%$ discordam quando se tratam de vagas para a população negra e cerca de $60 \%$, quando as vagas são voltadas para a população pobre. Nas entrevistas, os argumentos mais frequentes apresentados se referem à meritocracia, ao impacto na eficácia de implementação das políticas públicas ao selecionar uma mão-de-obra não "qualificada" e às oportunidades que já foram dadas ao instituir cotas para negros no ensino superior.

Todos os vinte e um servidores que foram entrevistados tinham algum conhecimento sobre ações que estavam sendo desenvolvidas para a população negra. A maioria declarou que apoiava as políticas de promoção da igualdade racial, 17 servidores. Entretanto, mostraramse divididos quando questionados especificamente sobre algumas ações voltadas a população negra. Mas, em relação ao questionamento sobre concursos públicos a maioria dos entrevistados declarou que não concordava, 14 deles; enquanto 3 entrevistados declararam que não sabiam responder se concordavam ou discordavam.

\subsection{Mérito}

Antes de analisarmos os relatos, vamos trazer conceitos que delimitam as entrevistas. Recorremos à discussão conceitual de Barbosa (1999) que esclarece que meritocracia tem duas vertentes. Uma, como critério lógico de ordenação social, onde o mérito é o "reconhecimento público da capacidade de cada um realizar determinada coisa ou posicionar-se numa determinada hierarquia com base nos seus talentos ou esforço pessoal" (BARBOSA, 1999:31). O mérito, dentro desse conceito de meritocracia, é invocado como critério de ordenação das pessoas de uma sociedade apenas em determinadas circunstâncias. Ou seja, há o reconhecimento de desigualdades naturais, as pessoas não são diferenciadas entre si olhando apenas os seus desempenhos, mas também atributos adquiridos ou por nascimento, por status ou poder.

Na segunda vertente, meritocracia é tratada como ideologia. Aqui o "valor é englobante, o critério fundamental e considerado moralmente correto para toda e qualquer ordenação 
social, principalmente no que diz respeito à posição socioeconômica das pessoas" (BARBOSA, 1999:31). Como ideologia meritocrática, somente a seleção dos melhores, baseado no desempenho individual, é considerado como legítimo e desejável. Isso quer dizer que as pessoas nasceram livres e iguais, nenhum atributo social como riqueza, status, ascendência, relações pessoais entre outros é levado em conta no tratamento que a sociedade dispensa aos seus membros.

Além do foco na pobreza, mérito foi o argumento recorrente para as propostas relacionadas a diferenciar a população negra no acesso a postos da administração pública ou universitários. O Entrevistado 15 enfatiza que o esforço pessoal é a condição mais correta para ter sucesso no concurso público, sobretudo porque o candidato já tem condições paritárias ao possuir curso superior ou o ensino médio.

Então é o seguinte, ele provavelmente, ele já passou por um curso superior ou ele tem o $2^{\circ}$ grau, tecnicamente ele está em pé de igualdade. Vale quem estudar mais. Eu mesmo estudei 6 anos para começar a passar em um concurso. Fiz um cursinho muito ruim, depois estudei sozinho, então sou a favor da meritocracia, acho que não tem que ter vaga para nenhuma raça, etnia, nem para índio e sou contra também para deficiente físico(...) (Entrevistado 15)

O Entrevistado 3 reconhece as falhas e as desigualdades existentes em um sistema que privilegia diretamente o mérito como ideologia. Mas, reitera a importância da efetividade da política pública sob a responsabilidade de um servidor competente.

(...) não estou falando que o sistema hoje seja meritocrático ou que escolha os melhores. Tem que escolher as pessoas mais capacitadas para poder implementar política pública, aí sim, se você consegue um bom quadro pessoal para implementar política pública, aí sim, você terá reflexo justamente para quem precisa se servir dessa política pública, acho que seria mais ou menos por aí. (Entrevistado 3)

Como o Entrevistado 3, a Entrevistada 21 também recorreu ao argumento da igualdade e da meritocracia, tão intimamente ligados às palavras de Barbosa (1999), pois a meritocracia é consequência lógica da primeira neste aspecto. Esta entrevistada defende que a linha de corte seria o curso superior, a partir daí a pessoa estaria em pé de igualdade para a disputa no mercado de trabalho público. 
Eu acredito que o Estado como empregador deve buscar a melhor mão-de-obra, a mais qualificada e fazendo, já inserindo os negros, os pobres, não só negros, até questão de pobres, já quando você abrir vagas na Universidade para eles acredito que então, a gente espera que no final do processo de aprendizado superior, ele já esteja em patamar de igualdade com os demais (Entrevistada 21)

Explorando um pouco mais a relação entre meritocracia e igualdade, Barbosa (1999) afirma que o sistema meritocrático é uma exigência da democracia. Considera que a meritocracia alia igualdade de oportunidades à eficiência na seleção das pessoas e à democracia, pois um dos princípios de uma sociedade democrática é garantir a igualdade de oportunidades para todos. Assim, segundo a autora, o princípio da igualdade é concretizado na medida em que as nomeações, as promoções e o reconhecimento público recaem sobre pessoas capazes, de competência reconhecida e comprovada, pois "as oportunidades estão abertas a todos e não se limitam a pessoas dotadas de relações pessoais e de parentesco ou possuidoras de status hereditário ou privilégios corporativos (BARBOSA, 1999:33). O Entrevistado 20 confirma os princípios argumentados pela autora.

Porque no momento que as pessoas tiverem o ensino superior elas já estariam num nível de igualdade de conhecimento. Não teria porque favorecer alguns em detrimento de outros. (Entrevistado 20)

Uma outra perspectiva semelhante é do Entrevistado 12.

\begin{abstract}
Na medida em que o governo fomente, incentive através de estímulos financeiros a formação do negro, dando-lhe melhores condições ele estará em ponto de igualdade de concorrer com pessoas de todas as raças; eu não iria para essa (cotas para negros nos concursos públicos, esclarecimento nosso), isso eu consideraria realmente um privilégio. (Entrevistado 12)
\end{abstract}

Aqueles que concordaram com proposta de vagas em concurso público para negros nas entrevistas nos deram respostas relacionadas a uma dívida histórica com a população, também à baixa representação da população negra nos quadros administrativos do Estado e ao sombreamento entre a questão racial e social no Brasil. Esses argumentos se aliam ao que Barbosa (1999) identificou como a meritocracia baseada em determinadas circunstâncias onde atributos e histórias de vidas são considerados para analisar o desempenho das pessoas. Vimos o argumento de reparação na fala do Entrevistado 13, onde atributos como o status e a história da população negra seria uma circunstância a ser considerada na sua participação nos quadros da administração pública. 
Sim porque nós temos uma dívida que não é apenas social. E a grande discussão que se coloca, cota racial...cota social... não, cota social não resolve. Não apenas a população negra é mais pobre, como mesmo entre os pobres e entre os ricos, você tem situações bem claras de tratamento desigual por uma questão de raça. (Entrevistado 13)

Ao se manifestar favorável às cotas em concursos públicos para negros, a Entrevistada 16 demonstrou que percebe a baixa representação da população negra na administração pública, tomando como exemplo a sua carreira.

(...) A gente ainda não vê uma participação efetiva de pessoas cuja origem racial é negra. É muito raro, acho que eu olho para o meu concurso, por exemplo, eu não vejo praticamente pessoas negras (...) já há uma reserva para ...deficientes físicos e as estatísticas mostram que aqueles alunos cotistas não deixam nada a desejar ao aluno...não deixam nada a desejar, acho que é só uma questão de tentar paulatinamente, deixar as regras de acesso mais justas e minimamente equitativas. Eu não vejo problema em relação a isso, acho que é razoável. (Entrevistada 16)

Argumento semelhante utilizou a Entrevistada 5 ao concordar com cotas em concursos públicos para negros. A representação do negro nos espaços da administração público onde a sua presença é inexistente.

Onde for necessária a representatividade da população brasileira, sim (exemplificou a carreira diplomática, esclarecimento nosso). (Entrevistada 5)

O Entrevistado 14 reconhece circunstâncias desiguais que atingem a população negra e consequentemente a sua deficitária inserção no aparelho do Estado, enfatiza a ideia de empoderamento do indivíduo ao promover-lhe independência econômica.

É fato que existe uma desigualdade gritante. Não só em relação ao negro, mas à camada grande da população brasileira necessitada, na verdade ela não tem essa estrutura, condições materiais que as outras classes possuem (...) as ações devem ser ações afirmativas, ações positivas, ações que possibilitem aquele indivíduo a crescer, evoluir, não ficar, implementar política pública de dependência econômica. (Entrevistado 14)

Atributos como ascendência e história da população negra também foram considerados pela Entrevistada 1 ao concordar com cotas para negros nos concursos públicos. 
(...) são pessoas tradicionalmente, historicamente, que tiveram menos acesso à educação. Não dispõem de recursos materiais para competir no mesmo nível que um aluno que acabou de formar na faculdade, o pai está bancando ele para estudar para concurso. (Entrevistada 1)

Ao não considerar as pessoas como tábulas rasas e seguindo nessa linha da representação e da falta de condições materiais para fazer parte do serviço público nas carreiras melhor remuneradas, um dirigente de políticas de promoção da igualdade racial expressou a sua percepção quanto à história de vida da população negra ser um obstáculo para voos mais ambiciosos na administração pública.

\footnotetext{
Nessas carreiras a presença de negros e negras é muito pequena. É preciso que se tenha...a história dos negros brasileiros na sua grande maioria é muito igual, seu pai deve ter a história parecida com a minha, com o meu pai. O pai do (citou o nome da pessoa que o entrevistado conhece, esclarecimento nosso), deve ser da mesma forma. Temos poucos, nossas histórias são muito parecidas. É preciso que nós estejamos ocupando cargos nessas posições fazendo o melhor, nos destacando na qualidade onde estamos e trabalhando nessa perspectiva de ação afirmativa. Também não adianta a gente ficar lá e achar que somos bem acolhidos porque somos bem formados (...) também em todas carreiras não têm presença de negros e negras. E não é porque nós não queremos, não, é que no processo anterior de ingresso a gente tinha que ficar entre comer ou não comer...trabalhar ou não trabalhar...como estudar se temos um...é mais difícil. (Dirigente 3)
}

Tivemos percepções que se manifestaram a favor de vagas nos concursos públicos para pobres em relação à população negra, temos os exemplos nas falas dos Entrevistados 9 e 10. Defendem a legitimidade das cotas sociais frente às cotas raciais, a despeito do entrevistado 9 argumentar sobre a história da população negra

(...) eu acho que a cota social é mais importante que a cota racial. Embora eu reconheça que há uma dívida histórica com a população negra, eu acho que a cota social é mais importante. (Entrevistado 9)

Aqui uma forte posição contra as cotas para a população negra nos concursos públicos:

(...) acho que deve estender para cota social, não deve ser só os negros, tem que pegar outros segmentos mais carentes da sociedade (...) existe também segmentos da sociedade de cor branca que também ostentam a condição de serem privados de recursos financeiros. (Entrevistado 10) 
Telles (2003) considera que cotas e políticas raciais são rejeitadas sob a alegação que contrariam o princípio da meritocracia. $\mathrm{O}$ autor baseia o seu argumento no levantamento que fez das ações que surgiram na justiça contra a aplicação da lei de cotas na Universidade Estadual do Rio de Janeiro-UERJ e nas seções de cartas dos jornais brasileiros. Santos (2009) ao aferir a opinião dos alunos de pós-graduação sobre o sistema de cotas da Universidade de Brasília, encontrou como principal argumento que "o mérito deve ser critério exclusivo de seleção para a universidade; que é preciso selecionar os melhores, independentemente da cor/raça do(a) candidato(a)”. Este autor revela que é difícil contraargumentar a ideia de meritocracia, pois ninguém seria contrário ao talento, à excelência e à inteligência como critérios reconhecidos no acesso ao ensino superior. Entretanto, problematiza sobre como reconhecer o mérito do indivíduo em que outras circunstâncias deveriam ser levadas em conta:

\begin{abstract}
Contudo, cremos que se faz necessário saber de quem é o mérito ou, se se quiser, quem tem mais mérito. Seriam aqueles estudantes que tiveram todas as condições normais para cursar o ensino fundamental e o médio e passaram no vestibular, ou serão aqueles que, apesar das barreiras raciais e de outras adversidades em sua trajetória, conseguiram concluir o ensino médio e também estão aptos para cursar uma universidade? Devemos considerar somente o mérito de chegada, aquele que se vê ou se credita somente no "cruzamento da linha de chegada": na aprovação do vestibular? Ou devemos considerar também o mérito de trajetória, aquele que se computa durante a vida escolar dos estudantes, que leva em consideração as facilidades e as dificuldades, os incentivos e as discriminações (raciais, de orientação sexual, de classe, de sexo, entre outras) no e do ambiente escolar dos alunos para concluírem os seus estudos? Santos (2009:354)
\end{abstract}

Telles (2003) discute que passar no vestibular tem mais relação com outras habilidades, como ter tempo e dinheiro para fazer um cursinho preparatório do que com a "habilidade em ter êxito na faculdade" (Telles, 2003:287). Segundo as análises teóricas do autor, a meritocracia conforme o conceito de origem é inalcançável o que se aproxima da vertente conceitual de meritocracia como ideologia discutida por Barbosa (1999) . A meritocracia preconiza recompensar o indivíduo com base na inteligência e nas habilidades cognitivas; segundo o autor isso não ocorre em lugar algum.

\footnotetext{
"A admissão à universidade parece, então, ser muito mais uma "testocracia" do que uma "meritocracia". A aprovação no vestibular é, na melhor das hipóteses, um teste de mérito muito questionável" (Telles, 2003:287).
} 
Telles (2003) baseia o seu argumento em pesquisas quantitativas realizadas nos Estados Unidos. Uma das pesquisas que o autor cita é a de Hauser ( 2002) que analisa o efeito de variáveis socioeconômicas nos resultados dos testes pós-ensino médio dos Estados Unidos e a relação entre habilidade cognitiva e origem social. Os dados são da pesquisa longitudinal WLS (Wisconsin Longitudinal Study) ${ }^{84}$ sobre adolescentes que terminaram o ensino médio. A pesquisa sugere que habilidade cognitiva ou mérito é apenas uma das variáveis que determinam o sucesso da vida de um indivíduo. Hauser ( 2002) questiona porque a ideia de mérito está sempre relacionada com habilidades cognitivas e não com outras condições e características como origem social e escolaridade que ampliam as chances de sucesso individual. $\mathrm{O}$ autor provoca com uma lista de outras possibilidades vinculadas ao conceito de mérito, como ambição, trajetória pessoal, perseverança, responsabilidade, habilidade física e artística, além de talento para acessar e formar redes sociais e econômicas. $\mathrm{O}$ autor reconhece que a inteligência tem um papel importante na estrutura complexa da nossa sociedade, mas é mais um dos fatores que contribuem para o sucesso individual além de outras condições como raça, sexo, localização geográfica e origem socioeconômica.

Outro estudo de três décadas sobre graduandos de Harvard demonstrou que, em razão de terem tido mais iniciativas, estudantes com baixos resultados na prova do SAT (Teste Padrão de Aptidão) dos Estados Unidos e originários da classe trabalhadora tiveram maior sucesso individual do que seus colegas de classe média (GUINIER; STURM, 2001 apud TELLES, 2003). Telles (2003) chama a atenção, ainda, que o mérito é uma definição imposta pelos grupos sociais dominantes. Uma percepção compartilhada por aqueles que dirigiram políticas de promoção da igualdade racial no governo federal.

\begin{abstract}
Aliados brancos que eram antirracistas e no primeiro momento proporcionaram isso é que o vestibular não era critério e nunca foi critério de avaliação de qualidade educacional, ele é um mero mecanismo de seleção por conta do pequeno número de vagas. E foi nos mostrando ao longo do tempo e muitos de nós passamos a estudar e verificar que o que ocorria naquela seleção não era falta de qualidade nem de competência dos jovens negros. Mas era um critério previamente estabelecido para beneficiar uma determinada categoria econômica que coincidentemente era formada basicamente por brancos. (Dirigente 1)
\end{abstract}

\footnotetext{
${ }^{84}$ Wisconsin Longitudinal Study (WLS) é uma pesquisa longitudinal com uma amostra aleatória de mais de 10 mil homens e mulheres. O foco são estudantes que concluíram o ensino médio na escola de Wisconsin. Os dados são de 1957 a 2011.
} 
Um outro aspecto ressaltado por esse mesmo dirigente é a condição de qualificação necessária para se avançar para outros níveis sociais. Uma possibilidade com a instituição de cotas no ensino superior.

\begin{abstract}
O segundo objetivo (no caso das cotas ensino superior, esclarecimento nosso) era que a gente pudesse ter competitividade no mercado de trabalho. Eu nunca...quer dizer...a resposta que mais nós militantes do movimento negro ouvimos na década de 70 e 80 era de que os negros não ocupavam determinadas posições porque não estavam qualificados para tal. Não eram músicos porque não sabiam ler a partitura; não eram professores, porque não estavam bem alfabetizados; não eram médicos porque não conseguiam passar no curso de medicina; não era piloto....ou seja era a ausência de capacitação técnica e educacional que impedia a presença do negro nos variados estamentos da sociedade e não o racismo estruturante existente na sociedade, ou seja a responsabilidade era nossa, éramos nós que não éramos capazes de alcançar a qualidade técnica necessária para ocupação desses espaços. (Dirigente 1)
\end{abstract}

Voltando-nos ao argumento contrário à instituição de vagas nos concursos públicos para negros - oportunidade anterior que essa população teve por meio do acesso ao ensino superior -, conforme os nossos entrevistados, essa condição levaria os negros a participarem de um processo de seleção em pé de igualdade. Vamos analisar, portanto, como se comportaram os nossos participantes em relação a uma ação que poderia dar sustentação a esse argumento. No questionário on-line, ao serem indagados sobre propostas de políticas públicas para que o Estado estimulasse, financeiramente, as Instituições de Ensino Superior Pública a implantar programas para ampliar o acesso de estudantes negros/as e pobres ao ensino superior, os nossos participantes mostraram-se mais favoráveis ao foco no estudante pobre do que ao estudante negro (Tabela 33). Pois, $78 \%$ discordavam que essa ação beneficiasse estudantes negros, mas concordavam quando a previsão era para estudantes pobres. Então, a questão paira no ar, como garantir um mesmo nível de igualdade para a disputa nos concursos públicos se também não há defesa das ações afirmativas para o acesso da população negra ao ensino superior. 
Tabela 33 - Cruzamento entre as variáveis Negros_IESAcesso e Pobres_IEAcesso (\%) Pobres_IESAcesso
Concorda Não conc. Discorda nem disc.

\begin{tabular}{|c|c|c|c|c|c|}
\hline \multirow{9}{*}{ 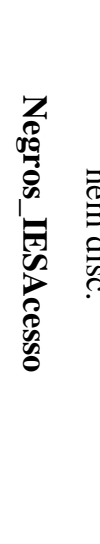 } & Negros_IESAcesso & 99,4 & 0,0 & 0,6 & 100 \\
\hline & Pobres_IESAcesso & 44 & 0,0 & 2,4 & 39,2 \\
\hline & Total & 39,0 & 0,0 & 0,2 & 39,2 \\
\hline & Negros_IESAcesso & 86,4 & 12,5 & 1,1 & 100 \\
\hline & Pobres_IESAcesso & 10,2 & 47,8 & 1,2 & 10,3 \\
\hline & Total & 8,9 & 1,3 & 0,1 & 10,3 \\
\hline & Negros_IESAcesso & 78,2 & 2,8 & 19,0 & 100 \\
\hline & Pobres_IESAcesso & 45,2 & 52,2 & 96,5 & 50,5 \\
\hline & Total & 39,5 & 1,4 & 9,6 & 50,5 \\
\hline Total & Negros_IESAcesso & 87,4 & 2,7 & 10 & 100 \\
\hline & Pobres_IESAcesso & 100 & 100 & 100 & 100 \\
\hline & Total & 87,4 & 2,7 & 10 & 100 \\
\hline
\end{tabular}

Todos aqueles que participaram da entrevista pessoalmente concordaram com a proposta de financiamento das IESs para o acesso em seus cursos de estudantes pobres, o argumento maciçamente utilizado foi a equalização de oportunidades para quem está em desvantagem financeiramente.

$\mathrm{Na}$ ação de inconstitucionalidade contra o sistema de cotas da Universidade de Brasília proposta pelo Partido Democratas e julgada pelo Supremo Tribunal Federal em 2012 ${ }^{85}$, Ao votar pela constitucionalidade do sistema adotado pela UnB, o relator e ministro do STF, Ricardo Lewandowski, considerou em seu voto a argumentação sobre o princípio da meritocracia. O relator traz para o debate jurídico que a Constituição Federal de 1988 acolhe a meritocracia como um parâmetro para a promoção da igualdade em seus níveis mais elevados. Esclarece que o princípio da meritocracia está relacionado com o princípio da igualdade material conforme quis o constituinte.

${ }^{85}$ Arguição de Descumprimento de Preceito Fundamental nº 186 


\begin{abstract}
Não raro a discussão que aqui se trava é reduzida à defesa de critérios objetivos de seleção pretensamente isonômicos e imparciais -, desprezando-se completamente as distorções que eles podem acarretar quando aplicados sem os necessários temperamentos. De fato, critérios ditos objetivos de seleção, empregados de forma linear em sociedades tradicionalmente marcadas por desigualdades interpessoais profundas, como é a nossa, acabam por consolidar ou, até mesmo, acirrar as distorções existentes. Os principais espaços de poder político e social mantém-se, então, inacessíveis aos grupos marginalizados, ensejando a reprodução e perpetuação de uma mesma elite dirigente. Essa situação afigura-se ainda mais grave quando tal concentração de privilégios afeta a distribuição de recursos públicos. (SUPREMO TRIBUNAL FEDERAL, 2009)
\end{abstract}

De fato, são recorrentes, os argumentos contrários e favoráveis a políticas de promoção da igualdade racial da forma como estão sendo implementadas no Brasil. Rocha-Pinto (2006), num trabalho de análise do processo de implantação das cotas na UERJ, mapeou alguns argumentos contrários e favoráveis à ação afirmativa. Argumentos contrários - “a) uma vez que a igualdade de todos perante a lei é um princípio estruturante da democracia, o sistema de cotas introduz a desigualdade em um sistema que deve ser igualitário; b) o mérito individual deve ser a única via de acesso a bens culturais escassos, como o acesso à universidade pública; c) existe grande dificuldade de demarcar exatamente os 'negros', os 'pretos' e os 'pardos' no Brasil por causa da miscigenação; d) a desigualdade no Brasil não se fundamenta na 'raça' ou na cor, mas na pobreza e na exclusão econômica, merecendo soluções universalistas, e não particularistas”. Argumentos favoráveis - “a) reparar uma herança de sofrimento e exclusão que remonta à escravidão e deve indenizar os herdeiros e as vítimas da escravidão e da discriminação; b) tratar desigualmente os desiguais, visto que os negros não são tratados como os brancos, o que justificaria ações compensatórias; c) promover uma elite negra, uma vez que todos os membros da elite (intelectual, econômica) são brancos; d) não cabe falar em mérito para ingresso no ensino universitário quando os pontos de partida são desiguais. O esforço pessoal, a superação individual de obstáculos pessoais e a discriminação também podem ser qualificados como mérito" (ROCHA-PINTO, 2006:148)

Para um dos nossos dirigentes entrevistados cada vez que houver algum tipo de reivindicação para implantação de políticas públicas focadas na população negra, o debate com os mesmos termos ressurgirá.

Sempre tem, quando você visibiliza o assunto...quando você instala o conflito dentro da...dentro do debate entre eles todos os argumentos que usaram contra as cotas voltam...todos eles...esse é um debate recorrente. (Dirigente 5) 


\subsection{Combate à pobreza}

Analisando os dados das tabelas cruzadas, Anexo A, entre as variáveis que mensuram o grau de concordância e discordância dos nossos respondentes sobre propostas de políticas públicas para pobres e negros, vemos que $99 \%$ daqueles que concordam com creche para negros, concordam com creches para pessoas pobres. Já, 93\% daqueles que discordam com creches para negros, concordam com creches para pobres (Tabela A1). As mesmas variações são encontradas para as demais variáveis, como vimos, $99 \%$ daqueles que concordam com cursinhos pré-vestibulares para negros, concordam também com cursinhos pré-vestibulares para pobres. Entre os $62 \%$ que discordaram de cursinhos para negros, concordaram com cursinhos pré-vestibulares para pobres (Tabela A2). Entre os respondentes que concordaram que o estímulo financeiro para as IES como forma de ampliar o acesso de estudante negros no ensino superior, $99 \%$ também concordaram com a mesma proposta para os estudantes pobres. Entre os que discordaram do estímulo financeiro para as IES, 78\% discordaram quando a proposta era para os negros, mas esse mesmo percentual concordou para os estudantes pobres (Tabela A3).

Quando questionados sobre as unidades de saúde localizadas em áreas em que a maioria dos moradores é da população negra, 99\% dos que concordaram também apoiavam para a população pobre. Já os $91 \%$ que discordaram sobre essa mesma questão para áreas com concentração negra, concordaram para as áreas pobres (Tabela A4). A construção de fábricas em áreas onde há uma concentração de pessoas negras, também, teve proporções semelhantes, $99 \%$ que concordavam, concordavam para as áreas pobres também; $71 \%$ que discordavam para locais onde há maioria negra, concordavam para a construção em áreas onde há pobres (Tabela A5). A proposta de reserva de vagas para negros e pobres nos concursos públicos foi a que apresentou proporções destoantes das demais variáveis. Acreditamos que a ideia de mérito tenha pesado na percepção dos nossos entrevistados. Na Tabela A6, observamos que $81 \%$ dos que concordam que deve reservar vagas para negros também concordam com essa proposta para os pobres; $19 \%$ que discordam dessa ideia para a população negra, concordam para a população pobre, ou seja, para os nossos respondentes não há público alvo certo para essa proposta. 
O que esses dados nos fazem refletir é que há uma associação da ideia de pobreza e negritude. Um Dirigente entrevistado nos confirmou essa percepção:

\begin{abstract}
As pessoas querem sempre casar a gente com outros...não estou discutindo pobreza. Pobreza você faz com outro tipo de programa, você faz com distribuição de renda, você faz com Bolsa Família, não queremos discutir isso. Queremos discutir a população negra, queremos saber o que acontece com ela, há um problema e esse problema tem que focar de forma exclusiva. (Dirigente 5)
\end{abstract}

Um outro dirigente viu nesse aspecto solidariedade do movimento negro com outras pautas além das suas:

Então, o movimento negro a meu ver deve receber o reconhecimento do seu protagonismo na luta pela pobreza. Pela emancipação dos pobres no Brasil. Quando as universidades começam a adotar cotas ou políticas de ações afirmativas para enfrentar o debate do racismo acabam fazendo escolhas via escolas públicas, por exemplo, a conquista do movimento negro alcança na verdade a juventude pobre do Brasil. (Dirigente 2 )

Omi (1994) discute que nos Estados Unidos o movimento social negro influenciou a organização dos demais movimentos de direitos civis, o chamando new social movements da década de 1960, como o feminismo, estudantil e dos homossexuais. No Brasil, o movimento social negro tem outra agenda, além da questão da pobreza. O dirigente 5 vê a composição de outras agendas como um "truque" para não atender a reivindicações feitas exclusivamente pelo movimento negro:

Se ele entra o que ele faz....qual é o grande truque que ele faz ...bom...política eu tenho uma política aqui que é uma política de integração da periferia que vai se chamar por exemplo, Juventude Viva, e esse programa vai pegar todo mundo, inclusive os negros. Ai o cara vai no debate e fala, eu estou fazendo...estou fazendo o Juventude Viva, então aquilo que era focado...que devia ser alguma coisa para a população (negra, esclarecimento nosso), ele volta para o discurso que ele fica mais à vontade...um discurso mais universal...eu estou fazendo para todo mundo, inclusive para os negros, também que são a maioria....ele faz isso. (Dirigente 5)

Estatisticamente, aqueles que argumentam que há uma relação entre pobreza e negritude não estão errados. O número de pobres pretos e pardos é 2,7 vezes maior do que o número de brancos segundo o Censo de 2010, em que 4,2 milhões de pessoas pobres se declaram brancas e 11,5 milhões, pretas e pardas. As pessoas entrevistadas nesta pesquisa quando concordavam que o Estado gastassem mais dinheiro nas creches e escolas localizadas em áreas onde a maioria dos moradores é da população negra, davam explicações que confirmavam o quanto a pobreza e negritude estão intimamente ligadas nas suas percepções. 
Sim. São tradicionalmente áreas pobres onde as mães não tem onde deixar os filhos para trabalhar. As crianças estão em situação de risco muito maior. É papel do Estado apoiar essas mulheres. (Entrevistada 1)

O Entrevistado 3 alia igualmente a questão racial e o combate à pobreza na seleção das políticas públicas

Aí eu acho que em vez do recorte ser uma questão racial, deveria ser de renda. O que deve ser levado em conta é pobreza. Se você levar em conta a pobreza, você está pegando justamente aquele segmento racial preterido do processo. Acho que teria que fazer um recorte de pobreza nesse caso. (Entrevistado 3)

Houve uma tentativa de problematizar a percepção que vincula pobreza e negritude pela Entrevistada 7. Esta foi uma percepção que encontramos de forma generalizada entre os nossos entrevistados.

Sim. Principalmente porque no Brasil pobreza e negritude vão muitos juntos. Então a maior parte dos pobres são negros, eu acho que isso aí está ok. O que eu acho que a gente tem que fazer é terminar com esta fase de sobreposição total entre pobreza e raça. Eu acho que podem haver pessoas pobres, digamos, mas que a pobreza e a negritude sejam tão coladinhas, é maldade, digamos assim. (Entrevistada 7)

O grau de pobreza da população negra também foi explorado pelo Entrevistado 9.

Sim, mas não só pelo fato de serem negros, mas no Brasil a maior parte da população pobre é negra. Então, mais pelo motivo social do que pelo motivo racial. É sempre que dentro do grupo de pobres, os negros são os mais pobres. Então, por esse motivo a gente estaria pegando entre os mais pobres, os mais pobres. (Entrevistado 9)

Como a população pobre é maciçamente negra, recai aí a legitimidade das ações universais do Estado que poderiam beneficiar de forma mais específica os negros. O que é uma percepção apreendida da Entrevistada 17.

Eu acho que no Brasil, a população negra, segundo os dados do IBGE, a população pobre é majoritariamente negra. Eu diria que é para a população pobre que acaba sendo para a população negra. Por que a população pobre é que precisa de mais recursos do Estado para suporte. (Entrevistada 17)

Percepção semelhante à da entrevistada citada anteriormente, encontramos na Entrevistada 19.

...estatisticamente a população negra ainda é a população mais pobre, então você está falando da população negra, você está falando da população mais pobre, para mim quem é a 
população predominantemente negra, quase sempre ela será hoje mais pobre. Nesses termos eu concordo. (Entrevistada 19)

A pobreza alia a negritude à eficiência das políticas públicas do Estado o que faz o Entrevistado 20 concordar com creches em bairros onde a maioria dos que ali moram é negra.

Porque no Brasil a maioria da população negra acaba sendo a população menos favorecida. Elas são pobres. Então eu concordo. (Entrevistado 20)

O que o movimento social negro e aqueles que se identificam com essa bandeira reivindicam é o combate ao racismo. Uma estratégia de ação diferente do combate à pobreza conforme afirmam os nossos dirigentes entrevistados. As ações afirmativas dentro de uma forma de implementação mais ampla é uma grande bandeira do movimento social negro como sugere a discussão de Gomes (2011). Acreditamos que as ações de promoção da igualdade racial buscam o empoderamento da população negra como forma de combate ao racismo, primeiro porque a presença de negros em posições de prestígio e poder poderia levar à dignificante experiência de pessoas brancas conviverem com negros longe de uma relação de subordinação ou de fatos negativos. O convívio positivo e paritário poderia dar fim ao estranhamento de negros fora do lugar comum e levar à naturalização da presença da população negra em diversos contextos sociais e econômicos. Um outro aspecto desse empoderamento seria a sinalização para as novas gerações como "o fim das barreiras cerceadoras do seu crescimento e ascensão" (GOMES, (2011:233) e poderia estimular os mais jovens a seguir bons exemplos de sucesso social e econômico. Finalmente, na nossa concepção, um terceiro aspecto do empoderamento da população negra é a valorização da sua identidade aliada ao autoreconhecimento da sua história, da sua estética, da cultura de matriz africana e da sua importância no desenvolvimento econômico e social do país. Vejamos o que diz o dirigente 5 sobre a necessidade de atuação mais ampla do Estado no combate ao racismo.

Muito confinado em duas, três áreas. Educação...Saúde e Cultura. As outras áreas estão passando ao largo do debate. Uma que está sempre atenta é o Ministério das Relações Exteriores, Defesa (Ministério da Defesa, esclarecimento nosso) está atenta, mas não entra. O Planejamento (Ministério do Planejamento, Orçamento e Gestão, esclarecimento nosso) está alheio a esse debate. O pessoal da Indústria e Comércio (Ministério da Indústria e Comércio, esclarecimento nosso). O pessoal da Integração Nacional (Ministério da Integração, esclarecimento nosso). Tudo isso que mexe com o nosso tema está alheio a isso (...) imagina na hora que a gente for discutir, por exemplo, com o Ministério de Integração Nacional (...) Mas, por exemplo, trazer um ator fundamental hoje para a discussão é o 
BNDES. O BNDES para nós seria importante para o debate. Só tem desenvolvimento no país se você levar em conta a solução desse problema (desigualdade racial, esclarecimento nosso). Essa é a discussão que nós temos que fazer para avançar, entendeu. Porque se a gente ficar confinado nessas três áreas que nos colocaram, a gente não avança. (Dirigente 5)

No nosso entendimento, há uma complexidade no debate porque apesar de as pessoas no Brasil acreditarem que haja racismo, ninguém é racista, como exemplificou em 1995 a pesquisa "Racismo Cordial" realizada pelo Instituto Datafolha. Conforme os dados daquela pesquisa, 95\% das pessoas entrevistadas admitiram conhecer alguma pessoa racista, mas apenas 5\% admitiram ter tido alguma atitude racista. Os dados da pesquisa apontam ainda que $95 \%$ das pessoas admitem que há racismo no Brasil, mas $90 \%$ declaram que não são racistas. Por isso, no caso brasileiro, como há racismo, mas não há racistas isso talvez leve os brasileiros a não compreenderem ou o não encararem com seriedade as práticas cotidianas e as estruturas que reproduzem as desigualdades raciais no Brasil. Fundamentos que sustentam o discurso dos movimentos sociais negros e as suas reivindicações que vai além do combate à pobreza. Talvez a questão seja de baixa compreensão para as pessoas sobre o que seja racismo e o que sejam atitudes racistas. Vale dizer que como os burocratas que participaram da nossa pesquisa estão no mundo, estão em sociedade, há uma escassa compreensão sobre os propósitos mais profundos ou aparentes das políticas públicas voltadas especificamente à população negra. É uma luta de difícil alcance como acreditam os nossos dirigentes entrevistados. O Dirigente 5 cita a invisibilidade do racismo no dia a dia da gestão pública.

\footnotetext{
Não ao racismo, mas ao racista...que é uma outra coisa. Racismo é uma coisa geral, para o indivíduo assumir é uma outra coisa...não...não você fazer...não tem problema...prova que eu sou racista. Você tem que saber o seguinte...quando você mexe com esse assunto você mexe com violência...é um processo violento de não deixar as coisas avançarem. Não tem uma coisa que mexe com a competência, mexe com a boa vontade... As pessoas não querem, não deixam e vão criar obstáculos para você não fazer. (Dirigente 5)
}

A institucionalização do racismo na administração pública é um aspecto a ser enfrentado no combate mais amplo do problema racial conforme afirma o Dirigente 1.

Então, quer dizer, quando eu digo que o racismo é estruturante, ele para ser estruturante ele precisa ser reproduzido permanentemente. E por onde ele se reproduz permanentemente? Primeiro, pelo processo educacional que é organizado, programado, comandando por quem? Pelo Ministério da Educação em todos os seus tentáculos, seguramente é onde você tem a maior capilaridade do Estado brasileiro, na área educacional. Qualquer buraquinho você tem uma escola, uma escola pública estadual, municipal e uma universidade. Qual é a segunda 
estrutura que você tem? A da segurança pública via repressão também você vai encontrar posto policial, delegacia, lá você tem o racismo institucionalizado e atuante de maneira radical porque através da força ou na força física, da pancada ou na força física do tiro, da bala dos grupos de extermínios. Presente (racismo, esclarecimento nosso) também nos critérios que você institui para proporcionar a mobilidade social ou a mobilidade dentro dos...da estrutura administrativa do governo. (Dirigente 1)

\title{
A falta de apoio especificamente para a questão racial, a despeito das pessoas defenderem e se envolverem em outros assuntos de direitos humanos, é um outro obstáculo relatado pelo
} Dirigente 2.

\begin{abstract}
Porque o racismo organiza a desigualdade brasileira, então você não...você depende de pessoas, depende da decisão de pessoas que fazem parte dessa cultura. E essa cultura é uma cultura de ignorar a singularidade do racismo como um fator organizador das desigualdades brasileiras. É muito comum você ter pessoas muito favoráveis às políticas emancipatórias, a políticas inclusivas, que são resistentes à utilização do critério raça/cor no desenho das políticas. É uma luta constante. (Dirigente 2)
\end{abstract}

Esse mesmo dirigente defendeu que a luta contra o racismo tem a sua singularidade. A instituição de políticas de promoção da igualdade racial no seu entender não deve ser moralizada, como se as pessoas estivessem agindo por princípios. $\mathrm{Na}$ opinião desse dirigente, o caminho deve ser pedagógico para ampliar apoiadores e simpatizantes à questão racial como forma de construir pontes para avançar suas agendas dentro do Estado.

\begin{abstract}
Aqueles que são contra políticas de ação afirmativa no critério raça /cor não são necessariamente racistas. Não são necessariamente pessoas que estão de acordo com essa desigualdade. É muito importante que essa luta pela democratização, a luta contra o racismo, você traga para esse campo de luta as pessoas que ainda não compreenderam ou não concordam integramente com o papel que o racismo tem na organização da nossa desigualdade. O que estou chamando de moralizar seria imputar a eles o estigma de serem racistas. Eles só são pessoas que têm uma visão distinta e é muito importante aprofundar o debate político com essas pessoas para que elas compreendam e adotem uma visão mais ativa no sentido da superação do racismo. Isso eu vivi em todos os níveis que eu trabalhei, pessoas muito comprometidas com a igualdade, com a justiça, mas não concordavam que o recorte racial era suficiente para o enfrentamento do racismo. (Dirigente 2)
\end{abstract}

Pois, ainda para o Dirigente 2, aqueles que se opõem às políticas de promoção da igualdade racial para a população negra são outros que tentam confundir o debate.

Atenção para não jogar no colo dos nossos verdadeiros adversários esses que têm uma visão distinta da nossa, mas que estão igualmente empenhados no combate e no enfrentamento da desigualdade brasileira. Eu acho que nós temos adversários muito duros e os meios de comunicação exemplificam diariamente pontos de vista que negam a existência do próprio racismo e vão até além de nos acusar, aqueles que estão contra o racismo, como nós, os racistas. Eu acho que é um campo de luta muito duro que não está ainda devidamente superado. Frequentemente voltam à tona temas e debates muito 
induzidos pelos meios de comunicação que tentam descaracterizar a luta antirracista e tentam caracterizar o Brasil como país de uma democracia racial existente. (Dirigente 2)

\subsection{Função do Estado}

No procedimento estatístico de regressão linear múltipla, a percepção sobre a função do Estado demonstrou ser um bom preditor da decisão dos burocratas sobre concordar ou discordar de propostas de políticas que beneficiem a população negra. Corremos o risco de sermos simplistas, mas não nos propomos realizar uma discussão exaustiva do quadro conceitual da função do Estado e do seu relacionamento com a sociedade, parece-nos mais interessante nos reter no que há de essencial nas principais ideias correntes sobre a questão do Estado para uma discussão e categorização das percepções dos nossos entrevistados. Isto se fará através de uma abordagem das linhas básicas sobre o que se entende por Estado com funções liberais, intervencionista e social democrata. Comumentemente, essas funções do Estado são analisadas sob a vertente econômica, mas elas estão imbuídas nos espaços políticos, culturais e filosóficos da sociedade.

A teoria liberal sustenta que o Estado não deve intervir na liberdade individual. Retomando a tradição liberal - que surge com o período renascentista do século XVII -, os neoliberais defendem a liberdade do indivíduo como fim último. Uma teoria que tem bases econômicas, pois o mercado decide um número maior de questões sem a interferência do Estado.

\footnotetext{
Quando a sociedade civil sob a forma de sociedade de livre mercado avança a pretensão de restringir os poderes do Estado ao mínimo necessário, o Estado como mal necessário assume a figura do Estado mínimo, figura que se torna o denominador comum de todas as maiores expressões do pensamento liberal. (BOBBIO, 2007:129)
}

O problema discutido por essa teoria é a concentração de poder em uma instituição, o Estado, que pode suprimir a liberdade do indivíduo. Essa é a principal característica da teoria liberal, a defesa do Estado mínimo, o Estado dever intervir o mínimo e deixar para o mercado a regulação da economia. Friedman (1977) enfatiza que o Estado é importante para garantir a liberdade de todos, entretanto, o Estado também é uma ameaça à liberdade. Este autor entende que o papel do Estado é manter a ordem e a lei; estabelecer e modificar os direitos de propriedade e de outras regras do jogo econômico; julgar as competições sobre as regras 
do jogo econômico; promover a competição e evitar o monopólio. A função seria fazer o que o mercado não pode fazer, determinar, arbitrar e fazer valer as regras do jogo.

Nessa mesma linha de argumentação, Buchanan defende que o papel do Estado é a garantia do contrato e a oferta de bens públicos que não são providos adequadamente pelo mercado (BUCHANAN, 1975 apud TONETO JR, 1996). A Teoria da Escolha Racional de Buchanan afirma que na esfera pública impera o autointeresse no sentido de que os indivíduos procuram maximizar os seus benefícios e reduzir seus custos de forma a ganhar cada vez mais. As pessoas estariam longe de pensar exclusivamente o bem geral. O Estado, nesse caso, tanto os políticos quanto os burocratas buscam maximizar os seus próprios benefícios como qualquer outro indivíduo na esfera privada, por isso a preferência desses grupos pelo "Estado grande" (TONETO JR, 1996). Buchanan acredita que o Estado poderia adotar novos arranjos como forma de aumentar o bem-estar social desde que os indivíduos entendessem que as novas regras sejam boas. Essas pessoas poderiam se manifestar a favor por meio do voto (TONETO JR, 1996).

O papel intervencionista do Estado ou Estado do Bem-Estar Social (welfare state) geralmente tem explicação de origem marxista. O Estado intervencionista surge da não sustentação do modelo liberal. Esse movimento gera o alastramento de intensos programas sociais e econômicos que se deve ao impacto da industrialização na vida das pessoas.

\begin{abstract}
O processo de industrialização capitalista é acompanhado de processos de desorganização e mobilização da força de trabalho, fenômeno que não se limita à fase inicial do capitalismo, mas que nela pode ser observado com especial clareza. A ampliação das relações concorrenciais aos mercados nacionais e finalmente mundiais, a introdução permanente de mudanças técnicas poupadoras da força de trabalho, a dissolução das formas agrárias de vida e de trabalho, a influência de crises cíclicas, etc. têm o efeito comum de destruir, em maior ou menor medida, as condições de utilização da força de trabalho até então dominantes. (OFFE; FREITAG, 1984:15)
\end{abstract}

O Estado intervencionista é funcional na medida em que gera uma série de programas sociais e econômicos de cunho reformista para dar conta de problemas estruturais da própria formação capitalista. A própria teoria marxista se preocupa essencialmente com a mudança social, aquela que coloca em crise um sistema e dele emerge um outro sistema qualitativo. 
Mas, longe de entrarmos no debate sobre abordagens de explicação do welfare state ${ }^{86}$, a tese fundamental da intervenção estatal é o Estado como um agente único na promoção de serviços públicos e o regulador da vida econômica, política e social da população.

Uma concepção ainda progressista defende que cabe ao Estado a promoção e a proteção dos indivíduos na suas relações sociais e no alcance da sua plena cidadania. Se isso cabe ao Estado, então é aceitável a pressão de grupos sociais mais desfavorecidos para que o Estado invista em políticas sociais que atendam a suas demandas. Portanto, a adoção de ideias keynesianas na constituição de um Estado denominado de socialdemocrata poderia levar à justiça social. O Estado social democrata tem na política social redistributiva a sua base, desenvolvendo uma ideologia ampla sobre o estado do bem-estar social. O modelo social democrata aceita uma intervenção estatal moderada, baseada na propriedade privada e em programas sociais que focalizem os mais desprotegidos.

$\mathrm{Na}$ vertente social democrata, Przeworsky (1995) discute que essa configuração estatal abandonou o projeto de nacionalização dos meios de produção, defendido pelo marxismo ortodoxo, para consentir que os capitalistas retenham uma parte da produção da sociedade porque esperavam obter cooperação dos capitalistas. O lucro apropriado seria poupado, investido, transformado em capacidade produtiva e parcialmente distribuído como remuneração a outros grupos. O Estado expande o seu corpo burocrático que trabalha em prol do bem-estar social de todos evitando políticas redistributivas radicais que, segundo Przeworsky (1995), resultam em crises econômicas que fogem do interesse dos assalariados. Nessa perspectiva o Estado social democrata desenvolve políticas que não modificam a estrutura da economia e nem o equilíbrio político de forças (PRZEWORSKY, 1995). A social democracia se fundamenta em concessões feitas pelo Estado e pela classe dominante para preservar o seus status quo.

Concordamos com Martins (1985) que a análise sociológica do Estado só tem sentido teórico e prático quando relacionada "às formas históricas concretas de organização e funcionamento do mercado e do sistema produtivo, da estruturação de classes e das condições em que representam seus interesses, dos graus da autonomia assumida pela

\footnotetext{
${ }^{86}$ Referência para essa discussão Arretche (1995) e Esping-Andersen (1991).
} 
dimensão política e do novo papel das burocracias nas diferentes sociedades capitalistas contemporâneas" (MARTINS, 1985:18). Acrescentamos também o relacionamento entre o Estado e outros segmentos que escapam de um conceito de classe. Ora, para Martins (1985), na medida em que o Estado se relaciona com as distintas sociedades capitalistas, desenvolve diferentes padrões e são esses padrões diferenciados que constituem problema sociológico. Mas, não nos propomos analisar um problema sociológico a partir da questão do Estado e nem problematizá-lo como tratamento empírico, vamos analisar os nosso dados com questões subjacentes aos três segmentos de abordagem teórica do Estado.

A Tabela 34 nos traz os dados quantitativos com alguns indícios da percepção dos nossos respondentes sobre a função do Estado. Num primeiro momento, poderíamos considerar que a maioria acredita que o Estado tem uma função essencial na organização da sociedade, cerca de $71 \%$ dos respondentes discordam que o Estado deva deixar o mercado coordenar a vida social como uma forma de se tornar mais democrático (MercadoVidaSocial). O mesmo aspecto poderia ser considerado, quando analisamos que $89 \%$ acreditam que o Estado deve resolver o problema da pobreza (ProblemaPobresApoioEstado). Mas, isso não sugere uma supressão da iniciativa privada em favor da intervenção estatal, pois quase $86 \%$ dos respondentes acreditam que o Estado deva promover alianças com o empresariado para executar estratégias de desenvolvimento nacional (AliançaEmpresários). No mesmo sentido, expressa a percepção de que o Estado organize a sociedade civil para com ela executar políticas públicas (SociedadeCivilPolíticasPúblicas), 69\% tiveram essa opinião, enquanto que $66 \%$ entendem que o Estado deve atender as demandas dos cidadão para se tornar mais democrático (DemandasCidadãoDemocrático). Esses percentuais indicam que a burocracia deste estudo tem uma visão mais predominante da função intervencionista do Estado com a participação do setor privado no desenvolvimento do país. 
Tabela 34 - Percepção dos servidores sobre as funções do Estado (\%)

\begin{tabular}{lccc} 
Funções do Estado & Concorda & $\begin{array}{c}\text { Não concorda } \\
\text { nem discorda }\end{array}$ & Discorda \\
OrdemLeisObedecidas & 48,36 & 9,25 & 42,39 \\
CapacitadasReconhecidas & 36,65 & 13,70 & 49,65 \\
PolíticasIguadadeSocEconômica & 90,63 & 3,51 & 5,85 \\
ProteçãoaTodos & 78,22 & 6,67 & 15,11 \\
ProblemaPobresApoioEstado & 89,23 & 6,21 & 4,57 \\
AliançaEmpresários & 85,83 & 8,31 & 5,85 \\
SociedadeCivilPolíticasPúblicas & 69,20 & 10,66 & 20,14 \\
MercadoVidaSocial & 14,29 & 14,99 & 70,73 \\
DemandasCidadãoDemocrático & 66,51 & 20,61 & 12,88 \\
\hline
\end{tabular}

Fonte: Dados primários - Elaboração da própria autora, 2014

A percepção dos nossos entrevistados sobre a função do Estado não difere daqueles que responderam ao nosso questionário. Todos esperam alguma intervenção estatal na vida social e econômica. Acreditam que as funções básicas do Estado são educação, saúde e segurança, áreas onde a presença do Estado deve ser muito forte, defendem os participantes deste estudo.

A Entrevistada 1 vê a necessidade da regulação e intervenção do Estado por um determinado momento que ela não nos precisou, mas que para esse momento chegar é necessário um nivelamento social e econômico.

O Estado brasileiro está no momento em que precisa intervir em questões pontuais para provocar um nivelamento para depois deixar ao sabor do mercado quem quer que seja. Mas esse momento como há uma grande diferença de formações que acessa serviços ele precisa intervir localmente. Num momento ideal acho que ele pode deixar ao sabor do mercado, mas agora não. (Entrevistada 1)

O Entrevistado 2 sem desconsiderar a função intervencionista do Estado, defende que a presença do Estado deve ser moderada. O papel motivador do Estado é constantemente ressaltado pelo entrevistado.

O Estado deve primeiro se preocupar com o cidadão. Procurar formular e executar políticas que sejam para atender o que a sociedade precisa. Por outro lado, eu não acho que o Estado vai fazer tudo. Ele tem que dar as condições, incentivar, reduzir distorções, desigualdades, permitir inclusão isso é o que eu acho que é o papel do Estado. Não necessariamente tem que executar isso, mas coordenar, permitir que isso aconteça. (...) Acho que o Estado, então, tem que viabilizar esse tipo de coisa (no caso educação, esclarecimento nosso). Incentivar, motivar, dar oportunidade. Então o Estado deve existir na medida certa, que permita que isso aconteça. Imagina se a gente for pensar que o Estado deva fazer tudo também, vai gerar um peso, imagina a estrutura que tem que ter para que ele faça tudo, e tem 
coisas que as pessoas fazem até voluntariamente. Outras coisas o mercado resolve e assim vai. Então aquilo que for no sentido de viabilizar acesso, viabilizar oportunidades, viabilizar cidadania, isso sim é o papel do Estado. (Entrevistado 2)

\title{
Um Estado que atue em áreas claramente demarcadas como sociais e deixar o mercado atuar nas relações econômicas. Essa percepção do Entrevistado 4 se aproxima da ideia social democrata.
}

\begin{abstract}
Na minha visão se tivéssemos um Estado menor, porém muito mais presente do que o atual, viveríamos numa sociedade mais igualitária. Se o dinheiro dos nossos tributos, dos nossos impostos fossem investidos em educação, em saúde, além, claro de outras atuações tópicas e deixasse a atuação de mercado, de produção de bens, de serviços para a iniciativa privada eu acredito que o resultado seria muito mais positivo do que os resultados que temos tido até agora, dessa forma priorizando o cidadão por meio da educação e da saúde. (Entrevistado 4)
\end{abstract}

A parceria do Estado com setores mais amplos, além do próprio mercado, também é uma visão dos nossos respondentes. A participação do terceiro setor é um princípio muito próprio da social democracia que tem uma relação muito estreita com as bases do welfare state. A Entrevistada 5 defende a necessidade do Estado nas regulações de certas relações econômicas, mas ao mesmo tempo a sua presença em áreas onde não há o alcance privado.

Em certas ocasiões eu acho que o Estado deveria atuar de forma universalista. Em certas situações, e eu falo de esgoto, saneamento, não é só unicamente para a população rica ou pobre, é para todos. Em outros aspectos eu acho que precisa da mão forte do Estado para conduzir políticas sociais em áreas onde não há interesse privado, nós vivemos num mundo capitalista, não há como negar isso. O Estado deveria realmente interferir no sentido de estimular um ou outro setor da economia. E por último também acho que a sociedade tem um papel fundamental na mudança do quadro, no contexto em que nós vivemos hoje. Não acho que o governo tem um papel de sozinho se responsabilizar por tudo dentro do universo da ampla gama de atribuições que é deferida ao Estado. Cada pessoa tem uma responsabilidade individual sobre como o mundo está se comportando hoje e como ele será no futuro e cada um tem que fazer a sua parte. Então nesse sentido é o setor privado (...) Acho que o Estado não tem condições financeiras de arcar para em benefício de todos, a gente não vive em um Estado comunista. A população é muito grande, a necessidade do ser humano é infinita e também acho que a iniciativa privada ela não vai agir sozinha em prol da mudança, ela precisa ser estimulada para que o interesse realmente venha de fato. (Entrevistada 5)

\section{O Entrevistado 12 não foge da representação social democrata.}

O papel deve estar moldado para o atendimento das necessidades básicas do cidadão, da sociedade no seu todo. Questão de saúde, segurança e educação. Essas são as atividades básicas que eu considero que o Estado deve intervir. Nas demais as atividades privadas é que deve tomar conta e adotar os procedimentos que atendam às necessidades das pessoas. (Entrevistado 12) 
Assim como, a Entrevistada 16 que confirma a nossa ideia de que os servidores participantes deste estudo têm uma tendência social democrata com a relativa intervenção do Estado e a participação da iniciativa privada.

(...) Então eu acredito que há mecanismos em que você pode deixar com uma regulação, um marco regulatório estável, com regras bem definidas, você pode contribuir com o desenvolvimento de atividades de infraestrutura, mediadas pelas próprias relações que se estabelecem no mercado. Poderia colocar o recurso público, mas naquelas áreas em que dificilmente vai conseguir atrair o setor privado. (Entrevistada 16)

Outro aspecto que merece ser analisado é a percepção dos nossos respondentes quanto a um viés conservador ou progressista do Estado. Tomamos como progressista a busca por justiça social e equalização de direitos. Quando indagados se acreditam que o Estado deve manter a ordem, pois as leis devem ser obedecidas sempre, mesmo se forem injustas vimos que $48 \%$ concordam com essa afirmativa, contra $42 \%$ que discordam (OrdemLeisObedecidas). Por outro lado, cerca de $50 \%$ discordam que o Estado deve garantir que as pessoas mais capacitadas sejam reconhecidas social e economicamente mais do que as pessoas menos capazes (CapacitadasReconhecidas). Outra questão nessa linha que queremos discutir, demonstra que, incoerentemente, $78 \%$ dos respondentes concordam que o Estado deve proteger a todos, sem distinção socioeconômica, de forma a não prejudicar quem venceu pelo próprio esforço (ProteçãoaTodos). Essas três últimas questões nos apontam a tendência dos nossos respondentes em ter uma posição moderada quando provocados sobre uma mudança social. Pois, se o Estado deve garantir a lei por mais que seja injusta; se não deve haver distinção socioeconômica e que, por outro lado, o Estado não deve preterir as pessoas menos capazes, leva-nos a considerar que algumas ideias não são convergentes. Aberbach, Putnam e Rockman (1981) chegam a conclusões semelhantes ao questionar os burocratas sobre de que forma acreditam que deva ser realizada mudanças sociais e políticas, $64 \%$ opinaram que elas devem ser moderadas, entre uma escala que variava de revolucionária a nenhuma mudança. Também, na nossa pesquisa, a posição moderada fomenta a discussão sobre mérito, pois a maioria dos respondentes, cerca de 91\%, concordam que o Estado implemente políticas públicas para prover a igualdade social e econômica entre as pessoas. Soa incoerente a defesa do mérito e a atuação do Estado em dar condições e oportunidades para ressaltar o próprio mérito. 
Um outro aspecto que exploramos foi a polaridade entre políticas universais e focalizadas. As entrevistas nos demonstraram que os participantes da pesquisa acreditam que há uma relação entre a função do Estado e o foco na condição da pobreza. Aqueles que são contrários a instituição de políticas de promoção da igualdade racial para a população negra quando provocados se o Estado deveria realizar algum tipo de focalização para realizar as políticas públicas, argumentam que a prioridade deve ser o combate à pobreza. A Entrevistada 5 acredita que a melhoria da educação em bases mais amplas teria como impacto a redução de desigualdades que levam à instituição de ações afirmativas atualmente.

Carente, pobre, acho o programa válido, mas isso precisa ser pensando a curto prazo, mas a médio e longo prazo é necessário que se melhore a educação de base para que essa política de ação afirmativa usada hoje na universidade seja extinta, que não se precise mais dela. (Entrevistada 5)

A tese de um Estado focado em populações mais vulneráveis é ampliada na fala do nosso Entrevistado 20 ao mencionar a focalização regional. Ainda que não privilegie em seus argumentos a focalização em critérios raciais, o entrevistado defende outros critérios como renda ou de gênero.

\begin{abstract}
Focalizar para determinados grupos, determinadas populações em situações de risco, eu acho que é fundamental não só, até não só atendendo a questão de renda ou gênero, ou atendendo à questão regional, dentro de uma regional, focalizar em diferentes grupos, eu acho que é muito importante (...) Eu acho que depende de algumas questões, por exemplo, a questão do Bolsa Família se for adotar uma política universal não vai chegar na ponta, então, nesse caso eu acho que não há uma política interessante e sim fazer a focalização. Agora uma política de educação acho que pode ser uma política universal de fazer investimento, de criar novos métodos de acesso, eu acho que pode ser, pode ser mais produtiva, ser uma política universal do que uma política focalizada. (Entrevistado 20)
\end{abstract}

O Entrevistado 11 declaradamente é contrário a uma focalização das políticas públicas em bases raciais. A responsabilidade pública para ele deve estar reduzida a populações mais pobres.

Repito, se tem uma classe que deveria ter acesso universal e gratuito a todos os bens públicos(...) é a classe mais pobre. Políticas de combate à miséria absoluta, eu acho que essas políticas têm que ser bem focalizadas. Mas insisto, a política de igualdade racial nesses termos, neste país me parece uma ideia fora de lugar, me parece uma ideia que foi comprada ao valor de face de uma cultura que não é nossa. (Entrevistado 11)

O mesmo argumento é apresentado pelo Entrevistado 6 cuja seletividade de programas governamentais são características de sociedades desiguais. Ele sugere maior inclusão dos mais pobres com uma adequada política de focalização. 


\begin{abstract}
Não que eu seja contra o universal, senão a gente vai entrar em um dilema. Em sociedades que são mais homogêneas é um debate que não tem muito sentido, a focalização e a universalização, em sociedades homogêneas, em sociedades que tem muita desigualdade, que é o nosso caso (...) mas eu acho que a atuação do Estado tem que ser mais focalizada (...) vamos supor que você faz a opção de se eu aumentar o salário mínimo, o impacto vai ser tanto. Mas eu vou trocar esse pacto que daria via salário mínimo, eu vou dar em programas como Bolsa Família, ampliar mais ainda o Bolsa Família para educação e saúde, focado em pessoas, para as famílias mais pobres (...) O grande problema no histórico é que o Estado subsidiou pessoas que não precisavam do apoio do Estado, pessoas de classe média e média alta. (Entrevistado 6)
\end{abstract}

Draibe (2003) ao analisar as políticas sociais do governo Fernando Henrique Cardoso e os seus efeitos sobre o sistema de proteção social no Brasil, explora a proposta de "focalizar no universalismo" (DRAIBE, 2003:91). As análises da autora levam a concluir que as propostas de políticas sociais implementadas no governo FHC não foram reduzidas exclusivamente ao enfrentamento da pobreza em detrimento das políticas de caráter universal. A universalidade das políticas públicas tinha no seu interior a focalização no combate à pobreza, as políticas sociais, além do eixo estruturador de desenvolvimento social, eram focalizadas para melhorar o impacto redistribuidor. A autora analisou esses aspectos tanto em políticas universais básicas, como educação e saúde, e também em programas específicos de combate à pobreza. $\mathrm{O}$ desenho das políticas públicas sociais eram orientações amplas com opções no seu interior de prioridades programáticas. Segundo Draibe (2003) a estratégia era assentar "no duplo objetivo de preservar a base universalista e democrática do welfare state e reduzir as chances da reprodução da desigualdade sob o manto de programas universais, frequentes sobretudo em sociedades muito desiguais" (DRAIBE, 2003:91).

Apesar dos nossos entrevistados considerarem a coexistência de políticas universais e focalizadas, não tiveram o alcance do desenho de políticas públicas analisado por Draibe (2003). Nesse plano, pelo menos, na opinião dos nossos entrevistados, mesmo que haja algum tipo de focalização, a priorização deve ser nas políticas universais que teriam como promover a igualdade para todos, ideia expressa pela Entrevistada 21.

Eu sei dos problemas que tem as políticas universais, principalmente pela questão de recursos para financiar é mais pesado e retém mais recursos (...) mas eu acho que o caminho é esse, é devagar, é difícil (...) em determinado momento você pode focar, mas nem por isso excluir, você pode colocar com maior foco para determinada população. (Entrevistada 21)

É importante observarmos que os entrevistados que se mostravam favoráveis às políticas públicas para a população negra, mesmo que parcialmente - pois alguns não eram favoráveis 
a vagas em concursos públicos para negros -, acreditavam na atuação universal do Estado. Mas do mesmo modo que o Estado deve ter um espectro universalista, deve atender segmentos e demandas específicas na focalização de determinadas políticas públicas. Ou seja, como defende a Entrevistada 19, a complexidade estaria em garantir um patamar mínimo de igualdade para se avançar ao total universalismo das políticas públicas.

O foco acaba tendo que ser diferente, eu não vejo como igualar situações de pessoas em extrema desigualdade social. O que eu acho é que a gente gerou nos últimos anos uma desigualdade tão grande que a gente precisa atingir um patamar que todos tenham aquele básico, aquele mínimo, hoje, a gente tem gente muito aquém desse mínimo. Talvez a partir desse momento, se pudesse fazer as tais políticas mais universais, hoje não tem jeito. (Entrevistada 19)

Raciocínio semelhante do Entrevistado 13, reconhecendo a necessidade das políticas públicas universais e focalizadas sob a responsabilidade do Estado.

Ao mesmo tempo que você tem que investir no acesso amplo e geral e irrestrito à educação e à saúde. Você tem que ter políticas focais de onde você tem esse déficit de atuação do Estado para que você consiga trazer essa população que está no déficit para uma situação de igualdade (...) Nós temos a necessidade de cotas agora, mas o acesso a cotas hoje, a política de cotas não tira a necessidade de termos acesso universal (...)Você não vai conseguir suprir todo o déficit que temos de cidadania, implementando somente políticas focalizadas e ao mesmo tempo você não vai suprir o déficit de cidadania se você tiver só políticas focalizadas e não tiver políticas universais. (Entrevistado 13)

A Entrevistada 16 também concorda com políticas focalizadas no enfrentamento dos problemas da população negra. Argumenta sobre a escassez de recursos que dê conta de políticas universais que inclua todos, por isso, a priorização de escolhas.

\begin{abstract}
Enquanto a gente tiver em um país com desigualdade social relevante, obviamente que a gente reconhece que isso vem diminuindo, a gente ainda vai precisar de políticas focalizadas. A gente não tem um cobertor tão extenso que possa nos permitir fazer uma política de universalização, que possa efetivamente abranger todos os setores, então obviamente é razoável que o Estado brasileiro dedique o seu olhar para aquilo, que são os mais, requerem um olhar mais detalhado (...) (Entrevistada 16)
\end{abstract}

Ainda tendo como inspiração a análise de Draibe (2003), pelo lado das políticas de promoção da igualdade racial - a focalização no enfrentamento do racismo no Brasil - o seu desenho programaticamente não está embutido no interior de políticas públicas universais. Dizendo claramente, o que ocorre é a focalização da política que já está focalizada. Uma rápida referência devemos fazer sobre a atual política de ingresso nas universidades públicas federais e nos institutos federais de educação para estudantes de escolas públicas de baixa 
renda. ${ }^{87}$ Esta política reserva $50 \%$ do total de vagas das instituições para estudantes de escolas públicas, subdividida em metade para aqueles estudantes com renda familiar bruta igual ou inferior a um salário mínimo e meio per capita e a outra metade das vagas para estudantes de escolas públicas com renda familiar superior a um salário mínimo e meio. Dentro desses percentuais, em ambos grupos de estudantes de escolas públicas, é considerado um percentual mínimo da soma de pretos, pardos e indígenas no estado conforme o Censo do IBGE. O que nós vemos nesse desenho é a seleção do critério racial no interior da política pública já focalizada na escola pública. Apesar de reconhecidamente ser um avanço na inclusão de estudantes oriundos de escolas públicas, não há nenhuma previsão de cotas raciais nos $50 \%$ das vagas restantes. Uma medida que não reconhece outros fatores intervenientes que não a renda como obstáculos para a população negra alcançar patamares de igualdades. O que nos faz chamar a atenção para a ilustração proposta pela Entrevistada 17 ao concordar com políticas de promoção da igualdade racial, trazendo argumento de cunho utilitarista.

\begin{abstract}
(...) foi uma charge que eu vi...um baixinho, uma criança de 3 anos precisa de um banco bem alto, uma de 5 de um banco menor, uma de 8 de um banco bem menor para chegar e ver em cima da cerca o jogo que está passando do outro lado do campo. Eu acho que é importante porque são pessoas que tem necessidades de ter oportunidades e que no fim acho que é só uma questão, uma incapacidade diria assim, não no sentido pejorativo, mas uma incapacidade de você não ver que essas políticas trariam um benefício geral e coletivo para mais adiante, no futuro, porque todos seriam beneficiados de não haver uma desigualdade tão gritante. (Entrevistada 17)
\end{abstract}

Retomo a questão de partida deste capítulo: a burocracia que participou deste estudo não tem uma representação ativa das necessidades da população negra. Os nossos participantes tendem a considerar muito mais relevantes políticas públicas de enfrentamento da pobreza.

Entre 1993-1995, Reis (2005) realizou um survey sobre a percepção de setores da elite brasileira como políticos, burocratas, líderes empresariais e líderes sindicais ${ }^{88}$. O survey foi uma base exploratória para a realização de pesquisa por meio de entrevistas abertas caracterizada como uma análise comparada internacional de setores mais ampliados da elite

\footnotetext{
${ }^{87}$ Lei no $12.711 / 2012$

${ }^{88}$ O survey era parte do projeto "Elites estratégicas e consolidação democrática", desenvolvido por um grupo de pesquisadores no Instituto Universitário de Pesquisas do Rio de Janeiro (Iuperj). O survey contou com uma amostra de 320 casos abordando questões sobre atitudes e valores políticos relacionados a questões de justiça e igualdade.
} 
dos países, África do Sul, Bangladesh, Brasil, Haiti, Índia e Filipinas. Além dos quatro setores já citados foram incluídas as elites militares, religiosas e intelectuais. No survey o estudo teve um escopo nacional, já na pesquisa internacional comparada buscaram detectar diferenças regionais. Houve uma seleção dos Estados do Rio de Janeiro, São Paulo, Bahia e Ceará. Em cada um desses estados foram realizadas entre 15 a 20 entrevistas.

As conclusões da autora assemelham-se aos nossos achados. Os seus entrevistados conferem uma alta prioridade a questões sociais. Para esse grupo um dos principais problemas do Brasil é educação, saúde, pobreza e desigualdade. Segundo a autora, as elites brasileiras têm um consenso em relação às políticas de ação afirmativa para minorias. Apesar de reconhecerem que há discriminação no Brasil contra negros e mulheres, a maciça maioria rejeitou políticas de instituição de cotas na educação e no mercado de trabalho. Tendem a apoiar fortemente programas universalistas para o combate à pobreza, essa preferência se soma explicitamente à condenação de políticas de ações afirmativas, pois, segundo a autora, a elite brasileira considera que elas são contrárias à igualdade de oportunidades.

Apesar de haver resistências de segmentos sociais à implantação de políticas de promoção da igualdade racial que favoreçam à população negra, houve alguns avanços nessa área. Os temas e propostas de políticas de combate ao racismo saíram das salas apertadas de grupos pioneiros dos movimentos sociais negros e ganharam as universidades, os gabinetes da administração pública, os espaços parlamentares e a mídia. Telles (2003) argumenta, no momento em que escreveu o seu trabalho, que tanto a esquerda como a direita eram generalizadamente contrárias à instituição de políticas raciais no Brasil. O que se vê é uma mutação de ideias, nos últimos tempos, interlocutores do neoliberalismo têm apoiado fortemente as iniciativas baseadas na raça. $\mathrm{O}$ autor salienta que, na época de sua análise, a esquerda, sobretudo o Partido dos Trabalhadores, dava forte apoio às iniciativas, mas ressalta que o apoio na cúpula do PT era fraco. Vimos no capítulo primeiro como ocorreu a negociação política para que se concretizasse as ações afirmativas para a população negra desde a campanha presidencial do então Presidente FHC, adentrando fortemente no governo Lula. 
O julgamento pelo STF sobre o sistema de cotas na Universidade de Brasília resolveu o imbróglio jurídico em relação a constitucionalidade desse tipo de ação afirmativa no Brasil. O Estatuto de Igualdade Racial também foi aprovado no Congresso Nacional, estabelecendo os marcos legais para a partir dali haver regulamentações por meio de decretos e tornar a aplicação da lei um fato. Como identificou um dirigente de políticas de promoção da igualdade racial, algumas pautas foram vitoriosas, pois “às vezes as vitórias são ignoradas e só as ausências são computadas" (Dirigente 2). Nesse campo maior avançou-se, não há insegurança jurídica e existe apoio político e social, então onde estão os gargalos para a implementação de políticas públicas que beneficiam marcadamente a população negra?

Em um seminário sobre políticas transversais organizado pela Escola Nacional de Administração Pública (Enap) no dia 18 de novembro de 2013, os palestrantes ali presentes nos deram uma indicação dos problemas enfrentados no dia a dia para fazer avançar o que a lei propugnava. Os palestrantes eram gestores de políticas para as minorias sociais: negros, LGBT (lésbicas, gays, bissexuais, travestis, transexuais e transgêneros), jovens e mulheres. As dificuldades que apontavam residiam desde a falta de servidores que se interessassem em conduzir esse tema no Estado, passando pela articulação institucional e a escassez de recursos orçamentários e financeiros. Problemas que já relatamos no capítulo primeiro, mas o que nos chamou a atenção foi o alcance dessas políticas nos estados e municípios brasileiros, o que nos diz muito sobre o modelo de federalismo no Brasil. Ocorre que se tranca o escoamento das ações derivadas no nível federal para os munícipios e estados. Quando todos os obstáculos são vencidos na União, nos demais níveis, onde de fato a política deve ser implementada, há uma inação que leva a baixa efetividade da política pública para esses segmentos. Os dirigentes entrevistados para esta pesquisa se manifestaram sobre a dificuldade de se alcançar resultados esperados, pois há um novo campo de luta. Vejamos o que diz o Dirigente 2.

Digo isso por causa da lei 10.639, as pessoas achavam que aprovando uma lei, nasceria uma mágica no imaginário brasileiro e na verdade o que nós constatamos é que acirrou a disputa do racismo, na hora em que você não tem força os seus adversários não ligam, quando você ganha força e corre para o enfrentamento se acirram as contradições, então por exemplo eu tinha notícia de escolas de periferia em que o movimento evangélico impedia as atividades culturais vinculadas à cultura negra por associá-la a religiosidade negra. Está entendendo...repara...você conquistou uma vitória, você avançou em uma concepção...o Estado aprovou isso...e você vai para a prática, você vai enfrentar, o racismo real, cotidiano na cabeça das pessoas, mesmo algumas negras, então...você perdeu? Eu não...você ganhou só que o campo de luta mudou... (Dirigente 2) 
Uma outra opinião sobre a continuidade do embate para a desconstrução do racismo vem do Dirigente 1.

\footnotetext{
(...) para a não implementação da lei 10.639 porque aí entra um viés dessa política que a presença das religiões ocidentais cristãs dentro do aparelho do Estado e cada uma ao seu modo, os católicos de um lado e os evangélicos de outro. Ambos trabalham no sentido da não implementação da lei 10.639 considerando que os elementos que a compõem são elementos religiosos de matriz africana, são demoníacos e que precisam ser combatidos. (Dirigente 1)
}

Tomada no seu conjunto, a institucionalização das políticas de promoção da igualdade racial vem como resultado de demandas de inclusão há muito tempo protestadas pelos movimentos sociais negros. O que constatamos é que ainda que não represente passivamente na sua categorização a população negra, a burocracia só será um braço das disputas sociais da população negra pelos recursos do Estado se entender as configurações políticas, sociológicas, filosóficas e de poder das políticas de promoção da igualdade racial.

\subsection{Conclusões preliminares}

Uma das questões basilares desta pesquisa era saber se a burocracia objeto deste estudo concordava ou não com proposições de políticas de promoção da igualdade racial para a população negra. Se as suas posições poderiam exprimir uma representação ativa dos interesses dos negros no Brasil. Seja em termos absolutos ou relativos, a maioria daqueles servidores que participaram desta pesquisa discordaram de políticas públicas específicas para a população negra. Essa mesma burocracia, por outro lado, mostrou-se favorável às mesmas propostas direcionadas à população pobre.

Com um perfil moderado politicamente, voltados para uma linha mais social democrata do Estado, os entrevistados utilizaram argumentos baseados na ideia de meritocracia ao discordar de políticas de promoção da igualdade racial para a população negra. Na nossa leitura, a maioria dos nossos participantes atribuíram pesos diferenciados para a questão da pobreza e racial, com prejuízo maior para esta última. $\mathrm{Na}$ visão da maioria dos nossos participantes a cor e/ou raça não é um determinante da condição de oportunidade e de acesso a instrumentos sociais para o alcance dessas oportunidades. 
Uma outra questão posta para este estudo foi a caracterização de burocracia estudada à luz da teoria da burocracia representativa. As carreiras deste estudo poderiam ser caracterizadas como uma burocracia de representação passiva ou ativa no que se refere à população negra? As nossas análises nos permitem supor que não há uma representação passiva, pois estão distantes do perfil demográfico da população brasileira, os negros são escassos nessas carreiras estudadas e elas são formadas sobretudo por homens. No aspecto da representação ativa não há uma postura de defesa dos interesses da população negra na constituição das políticas públicas do Estado.

A minoria de servidores participantes que se mostraram favorável às políticas de promoção da igualdade racial para a população negra constituem um indicativo de que há um espaço no Estado para o avanço dessas políticas. A burocracia reage às pressões do corpo político do Estado, entretanto não podemos negar a sua centralidade no processo de formulação e implementação de políticas públicas. Temos como princípio de que reconhecer a importância da burocracia não significa negar a influência maciça e determinante de outros atores sociais nas ações do Estado. 


\section{Conclusões finais}

Este trabalho busca analisar a efetividade das políticas de promoção da igualdade racial para a população negra sob a perspectiva de atuação da burocracia técnica. Problematizamos o caráter decisório dos servidores que atuam no Estado considerando a necessidade de responder sobre a baixa capacidade técnica e institucional das políticas voltadas à população negra. Realizamos a análise da efetividade pela escolha de um dos atores do processo de formulação, implementação e avaliação das políticas públicas, o burocrata técnico, mas especificamente aqueles servidores membros das chamadas Carreiras Típicas de Estado. Sem deixarmos, entretanto, de reconhecer o alto grau de influência que os políticos e outros segmentos da sociedade exercem sobre a tomada de decisões nas políticas públicas.

Lançamos mão da literatura sobre reconhecimento e redistribuição social para entendermos o objetivo das políticas de promoção da igualdade racial para a população negra. Pois, muito além de ser uma política compensatória, passa fortemente pelo reconhecimento da cultura e da importância da matriz africana para o desenvolvimento social e econômico no Brasil. Assim como, pela redistribuição da justiça social que busca compartilhar de forma mais justa direitos, bens e recursos para a população negra. No caso da política compensatória o argumento mais plausível é o processo histórico da população negra no Brasil que reflete a situação de desvantagem socioeconômica do presente. Já as reivindicações por reconhecimento passa por conseguir que as normas culturais dominantes não sejam o preço a pagar para se ter respeito e aceitação (FRASER, 2000).

Ilustrando a lógica de que o Estado é um espaço de disputa por recursos escassos, discutimos a atuação do movimento social negro na engrenagem do poder público. A partir de relatos daqueles que estiveram à frente das bandeiras de reivindicação do fortalecimento da identidade negra e das melhorias de condições de vida da população negra, entendemos as escolhas feitas e os caminhos da formulação e implementação traçados em relação às políticas para a população negra. Na história recente, o auge da atuação do movimento social negro se dá em 1995 com a Marcha de Palmares contra o Racismo, pela Cidadania e a Vida, em memória aos 300 anos da morte de Zumbi dos Palmares. Instante em que o movimento social negro articulou o apoio do governo e da oposição política para as suas bandeiras. Um 
outro fato marcante foi a participação de representantes do movimento social negro brasileiro na III Conferência Mundial contra o Racismo, a Discriminação Racial, Xenofobia e Intolerância Correlata em 2001 na África do Sul. Ali, foi onde tomou corpo a proposta de políticas de ações afirmativas por meio de cotas raciais nas instituições públicas de ensino superior.

Um outro aspecto, é que Estado não pode ser reduzido a sua burocracia, mas consideramos que ela seja um importante elo entre a estrutura pública e as demandas de segmentos sociais e econômicos. No que concerne às políticas de promoção da igualdade racial para as população negra, a burocracia seria um ponto de apoio para a conceituação técnica e para o enfrentamento da obscuridade dos procedimentos administrativos e burocráticos que faz com que a população negra seja afastada da operacionalização das políticas públicas. A teoria da burocracia representativa adota em seus métodos de análise a relação entre perfil sociodemográfico da burocracia e os seus comportamentos frente a decisões de políticas públicas. Os nossos dados demonstraram que não houve influência aparente das variáveis demográficas como sexo, cor/raça, idade, nível socioeconômico sobre a opinião dos participantes quanto a propostas de políticas públicas que beneficiam a população negra. Socialização organizacional, mensurada pela variável tempo de experiência na carreira também não teve nenhuma correlação com a variável dependente, propostas de políticas públicas para a população negra. Entretanto, a experiência em gestão, outra variável que mensura a influência da socialização organizacional sobre o comportamento dos participantes, mostrou ter alguma correlação com a variável dependente. A variável função do Estado também influenciou a posição dos participantes frente às políticas de promoção da igualdade racial.

Embora essas últimas variáveis influenciem o comportamento dos nossos participantes, vimos que a burocracia que participou deste estudo não está alinhada a propostas que garantiriam visibilidade à agenda política da população negra. Como seria de se esperar, as respostas dos participantes deste estudo aos nossos questionamentos não foram favoráveis. A maioria considera que essas políticas atentam contra o princípio da meritocracia e que a resolução dos problemas brasileiros se daria com políticas de combate à pobreza e de caráter universalistas. Na medida em que reclamamos a autonomia relativa do servidor de Estado 
como um sinal da sua atuação no plano decisório, ela mesma não é relevante para defender políticas voltadas à população negra.

As evidências dos dados levantados nesta pesquisa empurram para longe a categorização da burocracia técnica que participou deste estudo como representativa. Essa burocracia não representa a população negra como um espelho de sua composição demográfica, no caso representação passiva, e também não defendem as demandas dessa mesma população representação ativa. Os participantes deste trabalho reverberam na estrutura do Estado as mesmas ideias da população em geral sobre a população negra e suas reivindicações. Na medida em que não entendem a luta do movimento social negro que tornou o que era um estado de coisa em um problema de agenda política; na medida em que o princípio da meritocracia aplicado pura e simplesmente no Brasil contribui para a manutenção da crônica desigualdade racial e social, sobretudo quando há uma lógica perversa entre meritocracia e discriminação racial; na medida em que, após 126 anos de abolição da escravidão negra, as políticas universais têm sido insuficientes para combater o racismo e elevar as condições de vida da população negra. Osório (2009) demonstra que se a sociedade brasileira decidisse adotar fortemente políticas que combatessem a discriminação racial na educação e no trabalho e reduzissem as desigualdades de oportunidades, poderíamos levar menos de um século para que a renda média dos negros saltassem dos 48\% para 75\%-80\% na média dos brancos. Ainda assim, a desigualdade segundo o autor, seria bem visível.

Ao tomar como unidade de análise a burocracia técnica, evidenciamos os obstáculos para a institucionalização efetiva das políticas de promoção da igualdade racial, mas sem de modo algum ter exaurido o assunto. Esse trabalho procura contribuir com a literatura sobre relações raciais no que tange às políticas de promoção da igualdade racial, bem como fornece elementos para estudos nas áreas da burocracia e do Estado. Trouxemos para o debate a teoria da burocracia representativa, ainda inexistente na academia brasileira, mas largamente explorada no cenário internacional. Essa teoria nos auxiliou sobretudo a analisar a influência das características sociodemográficas da burocracia em relação a suas posições diante de propostas de políticas para a população negra.

Em outra ocasião, acreditamos que outros pesquisadores, com base na teoria da burocracia representativa, poderiam explorar o retrato da burocracia técnica aqui traçado. Sugerimos 
propostas de estudos sobre a relação entre a origem social da burocracia, a sua trajetória acadêmica, a sua trajetória profissional dentro e fora do serviço público com as suas crenças sociais e políticas; e sobretudo, em que medida esses atributos afetam o seu comportamento na atuação dentro da máquina pública. A ampliação desse estudo para a burocracia política são possibilidades que mapeariam o que faz, o que pensa e como age o Estado brasileiro do período republicano democrático. Por outro lado, a nosso ver, não tem porque reduzir o estudo da burocracia somente aos aspectos da linha de representação passiva, mas ir além, dentro do que se propõe a representação ativa, até que ponto o burocrata defende os interesses legítimos de segmentos sociais, políticos e econômicos. A conjugação de diferentes métodos de pesquisa quantitativa e qualitativa, como análises por meio de análise de discurso e história de vida, poderiam enriquecer muito o debate aqui proposto.

A outra linha de estudo, não necessariamente colada à burocracia, seriam os avanços e obstáculos da implementação de políticas de promoção da igualdade racial no caso específico para a população negra. Devemos supor que após dez anos de instituição das cotas raciais no ensino superior e da Lei 10.639 teríamos algumas evidências para discutirmos a aplicação das teorias de reconhecimento e redistribuição nas políticas de promoção da igualdade racial. O mais importante é a construção de uma matriz teórica e empírica sobre políticas para a população negra dentro das vertentes sociológica, política e da administração pública. 


\section{Bibliografia}

ABERBACH, Joel D.; PUTNAM, Robert D.; ROCKMAN, Bert A. Bureaucrats and politicians in western democracies. Cambridge: Harvard University Press, 1981.

ABRUCIO, Fernando Luiz; PEDROTI, Paula; PÓ, Marcos Vinicius. Formação da burocracia brasileira: a trajetória e o significado das reformas administrativas. Burocracia e política no Brasil: desafios para a ordem democrática no século XXI. Rio de Janeiro: FGV, 2010.

AGUIAR, Neuma; FERNANDES, Danielle; NEVES, Jorge Alexandre. Mobilidade social feminina. In: AGUIAR, Neuma (Org.). Desigualdades sociais, redes de sociabilidade e participação política. Belo Horizonte: UFMG, 2007. p. 165-180.

ALBERTI, Verena; PEREIRA, Almicar Araujo. A defesa das cotas como estratégia política do movimento negro contemporâneo. Revista Estudos Históricos, v. 1, n. 37, p. 143-166, 2006.

ALBERTI, Verena; PEREIRA, Almicar Araujo. Histórias do movimento negro no Brasil: depoimentos ao CPDOC. Rio de Janeiro: CPDOC-FGV, 2007.

ALENCAR, Rafael Augusto da Costa. Ações afirmativas no Brasil: um estudo de caso sobre o Estatuto da Igualdade Racial. 2011. Dissertação de mestrado - Universidade de Brasília, Brasília, 2011.

ALMEIDA, Alberto Carlos; YOUNG, Clifford. A cabeça do brasileiro. Rio de Janeiro: Editora Record, 2007.

ALTHUSSER, Louis. Ideologia e aparelhos ideológicos do Estado. Lisboa: Presença, 1980.

ALVES, Maria Teresa Gonzaga; SOARES, José Francisco. Medidas de nível socioeconômico em pesquisas sociais: uma aplicação aos dados de uma pesquisa educacional. Opinião Pública, v. 15, n. 1, p. 1-30, 2009.

ANDERSON, James E. Public policymaking: an introduction. 3rd. ed. Boston: Houghton Mifflin Harcourt (HMH), 1984.

APPIAH, Kwame. Na casa de meu pai. Rio de Janeiro: Contraponto, 1997.

ARAUJO, Tereza Cristina N. A classificação de cor nas pesquisas do IBGE: notas para uma discussão. Cadernos de Pesquisa, n. 63, p. 14-16, 1987.

ARON, Raymond. As etapas do pensamento sociológico. $7^{\mathrm{a}}$ ed. São Paulo: Martins Fontes, 2008 .

ARRETCHE, Marta T.S. Emergência e desenvolvimento do Welfare State: teorias explicativas. BIB: Boletim Informativo e Bibliográfico de Ciências Sociais, v. 39, p. 3-40, 1995. 
AZERÊDO, Sandra. Teorizando sobre gênero e relações raciais. Estudos Feministas, p. 203, 2008.

BAIRROS, Luiza. Nossos feminismos revisitados. Estudos Feministas, v. 3, n. 2, p. 458, 2008.

BARBOSA, Lívia. Igualdade e meritocracia: a ética do desempenho nas sociedades modernas. 2a . ed. [S.1.]: FGV Editora, 1999.

BERNARDINO-COSTA, Joaze. Ação afirmativa e a rediscussão do mito da democracia racial no Brasil. Estudos afro-asiáticos, v. 24, n. 2, p. 247-273, 2002.

BLISHEN, Bernard R. The construction and use of an occupational class scale. The Canadian Journal of Economics and Political Science/Revue canadienne d'Economique et de Science politique, v. 24, n. 4, p. 519-531, 1958.

BOBBIO, Norberto. Estado, governo, sociedade: para uma teoria geral da política. Rio de Janeiro: Paz e Terra, 2007.

BOGUE, Donald J. Skid row in American cities. [S.1.]: Community and Family Study Center, University of Chicago, 1963.

BONIS, Daniel de; PACHECO, Regina Silva. Nem político nem burocrata: o debate sobre o dirigente público. Burocracia e política no Brasil : desafios para a ordem democrática no século XXI. Rio de Janeiro: Editora FGV, 2010. p. 329-362.

BOURDIEU, Pierre. La noblesse d'État: grandes écoles et esprit de corps. Paris: Les Editions de Minuit, 1989.

BRADBURY, Mark D.; KELLOUGH, J. Edward. Representative bureaucracy: exploring the potential for active representation in local government. Journal of Public Administration Research and Theory, v. 18, n. 4, p. 697-714, 2008.

BRUDNEY, Jeffrey L.; HEBERT, F. Ted; WRIGHT, Deil S. From organizational values to organizational roles: examining representative bureaucracy in state administration. Journal of Public Administration Research and Theory, v. 10, n. 3, p. 491-512, 2000.

BUCHANAN, James M. The limits of liberty: between anarchy and Leviathan. Chicago: University of Chicago Press, 1975.

CÂMARA, Leonor Moreira. O cargo público de livre provimento na organização da administração pública federal brasileira: uma introdução ao estudo da organização da direção pública na perspectiva de estudos organizacionais. Revista de Administração Pública, v. 43, n. 3, p. 635 a 659, 2009.

CARDOSO, Fernando Henrique. Mãos à obra, Brasil: proposta de governo. Rio de Janeiro: Centro Edelstein de Pesquisas Sociais, 1994.

CARVALHO, Eneuton Dornelles. Salários e política de vencimentos no poder executivo federal na primeira década de 2000. In: CARDOSO JR., José Celso (Org.). Burocracia e 
Ocupação no Setor Público Brasileiro (Diálogos para o Desenvolvimento). Rio de Janeiro: Ipea, 2011. p. 133-178.

CARVALHO, Juan P. C. 15 anos da Advocacia-Geral da União: breve retrato do maior escritório de advocacia do país. Direito e Liberdade, v. 9, n. 2, p. 95-118, 2009.

CAVALCANTI-SCHIEL, Ricardo. Quando nem todos os cidadãos são pardos. Divisões perigosas. Políticas raciais no Brasil contemporâneo. Rio de Janeiro: Civilização Brasileira, p. 263-270, 2007.

CAVENAGHI, Suzana. Gênero e raça no ciclo orçamentário e controle social das políticas públicas: indicadores de gênero e de raça no PPA 2008-2011. [S.1.]: CFEMEA, 2007.

CHEIBUB, Zairo Borges; MESQUITA, Wania Amélia Belchior. Os Especialistas em Políticas Públicas e Gestão Governamental: avaliação de sua contribuição para políticas públicas e trajetória profissional. Texto para Discussão. Brasília: ENAP, 2001.

COLEMAN-SELDEN, Sally; BRUDNEY, Jeffrey L.; KELLOUGH, J. Edward. Bureaucracy as a representative institution: Toward a reconciliation of bureaucratic government and democratic theory. American Journal of Political Science, 3. v. 42, p. $717-$ 744, jul. 1998.

COLEMAN-SELDEN, Sally. The promise of representative bureaucracy: Diversity and responsiveness in a government agency. London: ME Sharpe, 1998.

COSTA, Sergio. A mestiçagem e seus contrários etnicidade e nacionalidade no Brasil contemporâneo. Tempo social, v. 13, n. 1, p. 143-158, 2001.

COSTA, Valeriano Mendes. Sistema de governo e administração pública no brasil. In: JACCOUD, Luciana; ANDRADE, Regis de Castro (Org.). Estrutura e Organização do Poder Executivo. Brasília: Centro de Documentação, Informação e Difusão Graciliano Ramos, 1993. v. 2. p. 203-268.

D'ARAÚJO, Maria Celina; LAMEIRÃO, Camila. A elite dirigente do governo Lula. Rio de Janeiro, 2009.

D’ARAÚJO, Maria Celina Soares; FARIAS, Ignez Cordeiro de; HIPPOLITO, Lucia. Ipea 40 anos uma trajetória voltada para o desenvolvimento: depoimentos ao CPDOC. Rio de Janeiro: CPDOC-FGV, 2005.

D'ARAÚJO, Maria Celina Soares; LAMEIRÃO, Camila. Dirigentes públicos federais de alto escalão no governo Lula. In: CARDOSO JR., José Celso (Org.). Burocracia e Ocupação no Setor Público Brasileiro (Diálogos para o Desenvolvimento). Rio de Janeiro: Ipea, 2011. v. 5. p. 91-131.

DOGAN, Mattei. The mandarins of Western Europe: The political role of top civil servants. New York: Sage Publications, 1975. 
DOLAN, Julie. Representative bureaucracy in the federal executive: gender and spending priorities. Journal of Public Administration Research and Theory, v. 12, n. 3, p. 353-375, jul. 2002.

DOLAN, Julie A.; ROSENBLOOM, David H. Representative bureaucracy: Classic readings and continuing controversies. London: ME Sharpe, 2003.

DRAIBE, Sonia. A política social no período FHC eo sistema de proteção social. Tempo social, v. 15, n. 2, p. 63-101, 2003.

DYE, Thomas R. Understanding public policy. New Jersey: Prentice Hall New Jersey, 1972.

EGEBERG, Morten; GORNITZKA, Åse; TRONDAL, Jarle. People who run the European Parliament. Disponível em: <http://www.iias-iisa.org/egpa/wpcontent/uploads/020_Egeberg-

People_who_run_the_European_Parliament_Staff_demography_and_its_implications18PSGXIV.pdf>. Acesso em: 04 set 2014.

ERIKSON, Robert; GOLDTHORPE, John H. Commonality and variation in social fluidity in industrial nations. Part I: A model for evaluating the FJH hypothesis. European Sociological Review, v. 3, n. 1, p. 54-77, 1987a.

ERIKSON, Robert; GOLDTHORPE, John H. Commonality and variation in social fluidity in industrial nations. Part II: the model of core social fluidity applied. European Sociological Review, v. 3, n. 2, p. 145-166, 1987b.

ERIKSON, Robert; GOLDTHORPE, John H. The class Schema of the CASMIN Project. In: CASMIN CONFERENCE, mar. 1988, Guenzburg, Federal Republic of Germany. Anais. Guenzburg, Federal Republic of Germany: [s.n.], mar. 1988.

ERIKSON, Robert; GOLDTHORPE, John H.; PORTOCARERO, Lucienne. Intergenerational class mobility in three Western European societies: England, France and Sweden. The British Journal of Sociology, v. 30, n. 4, p. 415-441, 1979.

ERIKSON, Robert; GOLDTHORPE, John H.; PORTOCARERO, Lucienne. International class mobility and the convergence thesis: England, France and Sweden'. British Journal of Sociology, v. 34, p. 303-343, 1983.

ERIKSON, Robert; GOLDTHORPE, John H.; PORTOCARERO, Lucienne. Social fluidity in industrial nations: England, France and Sweden. The British Journal of Sociology, v. 33, n. 1, p. $1-34,1982$.

ESPING-ANDERSEN, Gosta. As três economias políticas do Welfare State. Lua Nova: Revista de Cultura e Política, n. 24, p. 85-116, 1991.

FARAH, Marta Ferreira Santos. Administração pública e políticas públicas. Revista de Administração Pública-RAP, v. 45, n. 3, p. 813-36, 2011. 
FERES JÚNIOR, João. Aspectos normativos e legais das políticas de ação afirmativa. In: FERES JÚNIOR, João; ZONINSEIN, Jonas (Org.). Ação afirmativa e universidade: Experiências nacionais comparadas. Brasília: Editora Universidade de Brasília, 2006.

FIELD, Andy. Descobrindo a estatística utilizando o SPSS. 2a . ed. Porto Alegre: Artmed, 2009.

FRASER, Nancy. A justiça social na globalização: redistribuição, reconhecimento e participação. Revista crítica de ciências sociais, n. 63, p. 07-20, 2002.

FRASER, Nancy. Reconhecimento sem ética. Lua Nova, v. 70, p. 101-138, 2007.

FRASER, Nancy. Redistribución, reconocimiento y participación: hacia un concepto integrado de la justicia. [S.1.]: In: Unesco. Informe Mundial sobre la Cultura, 2000.

FRASER, Nancy; HONNETH, Axel. Redistribution or recognition?: a politicalphilosophical exchange. London New York: Verso, 2003.

FRIEDMAN, Milton. Capitalismo e liberdade. São Paulo: Artenova, 1977.

FRY, Peter. Divisões perigosas: políticas raciais no Brasil contemporâneo. Rio de Janeiro: Editora Record, 2007.

FRY, Peter. O que a Cinderela negra tem a dizer sobre a "política racial" no Brasil. Revista Usp, v. 28, p. 122-135, 19961995.

GANZEBOOM, Harry BG; DE GRAAF, Paul M.; TREIMAN, Donald J. A standard international socio-economic index of occupational status. Social science research, v. 21, n. 1, p. 1-56, 1992.

GANZEBOOM, Harry BG; TREIMAN, Donald J. Internationally comparable measures of occupational status for the 1988 International Standard Classification of Occupations. Social science research, v. 25, n. 3, p. 201-239, 1996.

GEMAA (Grupo de Estudos Multidisciplinar da Ação Afirmativa). Disponível em: <http://gemaa.iesp.uerj.br/>. Acesso em: 24 mar. 2014.

GILROY, Paul. Entre campos, nações, culturas e o fascínio da raça. [S.1.]: Annablume, 2007.

GODOY, André Luz de; TEIXEIRA, Sonia Maria Fleury. A burocracia federal brasileira e o sincretismo de relações Estado-sociedade: o caso dos Especialistas em Políticas Públicas e Gestão Governamental. Encontro Anual da Associação Nacional de Pós-graduação e Pesquisa em Administração, v. 33, 2009.

GONZALEZ, Lélia. Entrevista concedida à revista SEAF - Sociedade de Estudos e Atividades Filosóficas. Republicada em UAPÊ Revista de Cultura $\mathrm{n}^{\circ} 2$ "Em cantos do Brasil". 
GOMES, Joaquim Barbosa. Ação afirmativa e princípio constitucional da igualdade: o direito como instrumento de transformação social: a experiência dos EUA. Rio de Janeiro: Renovar, 2001.

GOMES, Joaquim Barbosa. O uso da lei no combate ao racismo: direitos difusos e ações civis públicas. In: GUIMARÃES, Antonio Sérgio Alfredo; HUNTLEY, Lynn (Org.). Tirando a Máscara: ensaios sobre o racismo no Brasil. São Paulo: Paz e Terra, 2000. p. 389-409.

GOMES, Nilma Lino. O movimento negro no Brasil: ausências, emergências e a produção dos saberes. Política \& Sociedade, v. 10, n. 18, p. 133-154, 2011.

GOUVÊA, Gilda Portugal. Burocracia e elites burocráticas no Brasil. São Paulo, SP: Editora Paulicéia, 1994.

GRAY, David E. Pesquisa no mundo real. 2a . ed. Porto Alegre: Artmed - Grupo A, 2011.

GROSFOGUEL, Ramón. Para descolonizar os estudos de economia política e os estudos pós-coloniais: transmodernidade, pensamento de fronteira e colonialidade global. Epistemologia do Sul, p. 383-417, 2009.

GUEDES, André Teles. Elites estatais e reforma do Estado na Nova República: o projeto ENAP e a formação da carreira de gestor governamental no Brasil. 2013. Tese de doutorado - Universidade de Brasília, Brasília, 2013.

GUIMARÃES, Antonio Sérgio Alfredo. Racismo e anti-racismo no Brasil. 1 ${ }^{\mathrm{a}}$. ed. São Paulo: Editora 34, 1999.

GUIMARÃES, Antonio Sérgio Alfredo. Classes, raças e democracia. São Paulo: Editora 34, 2002a.

GUIMARÃES, Antonio Sérgio Alfredo. Democracia racial. Cadernos PENESB. Relações Raciais e Educação: temas contemporâneos. Niterói: UFF, $2002 \mathrm{~b}$.

GUIMARÃES, Antonio Sérgio Alfredo. Como trabalhar com“ raça” em sociologia. Educação e Pesquisa, v. 29, n. 1, p. 93-107, 2003.

GUIMARÃES, Antonio Sérgio Alfredo. Entre o medo de fraudes e o fantasma das raças. Horizontes Antropológicos, v. 11, n. 23, p. 215-217, 2005.

GUIMARÃES, Antonio Sérgio Alfredo. Depois da democracia racial. Tempo Social: revista de sociologia da USP, v. 18, n. 2, 2006.

GUIMARÃES, Patrícia de Almeida Barbosa. A Advocacia Pública da União e a independência funcional dos seus membros: possibilidades e limites. 2012. Disponível em: <http://dspace.idp.edu.br:8080/xmlui/handle/123456789/224>. Acesso em: 1 out. 2013.

GUINIER, Lani; STURM, Susan. Who's Qualified? A New Democracy Forum on the Future of Affirmative Action. Boston: Beacon Press, 2001. 
HAIR, Joseph F. et al. Análise multivariada de dados. 5ª ed. Porto Alegre: Bookman, 2007.

HARMON, Michael M. Responsibility as paradox: a critique of rational discourse on government. New York: Sage Publications, 1995.

HAUSER, Robert Mason. Meritocracy, cognitive ability, and the sources of occupational success. Wisconsin: Center for Demography and Ecology, University of Wisconsin, 2002.

HECLO, Hugh. A government of strangers: executive politics in Washington. Washington: Brookings Institution Press, 1977.

HONNETH, Axel. Luta por reconhecimento: a gramática moral dos conflitos sociais. $1^{\mathrm{a}}$. ed. São Paulo: Editora 34, 2003.

HOOKS, Bell. et al. Vamos Falar a Verdade sobre o Feminismo (Depoimentos a revista Ms). Estudos Feministas, v. 2, n. 3, p. 162, 2008.

HOWLETT, Michael Patrick; RAMESH, M. Studying public policy: policy cycles and policy subsystems. Don Mills, Ont.: Oxford University Press, 2003.

HUGHES, Michael; TUCH, Steven A. Gender differences in whites' racial attitudes: Are women's attitudes really more favorable? Social psychology quarterly, p. 384-401, 2003.

IPEA. Avanços e desafios da transversalidade nas políticas públicas federais voltadas para as minorias. Brasil: o estado de uma nação.Brasil em desenvolvimento: Estado, planejamento e políticas públicas, Volume 3. Brasília: Ipea, 2009. Acesso em: 28 ago. 2012.

JACCOUD, Luciana. O combate ao racismo e à desigualdade: o desafio das políticas públicas de promoção da igualdade racial. In: THEODORO, MÁRIO (Org.). As políticas públicas e a desigualdade racial no Brasil: 120 anos após a abolição. Brasília: Ipea, 2008.

JACCOUD, Luciana; BEGHIN, Nathalie. Desigualdades raciais no Brasil: um balanço da intervenção governamental. Brasília: Ipea, 2002.

JANNUZZI, Paulo de Martino. Construção de uma escala sócio-ocupacional: notas metodológicas e resultados. Revista Brasileira de Estatística, v. 60, n. 214, p. 7-24, dez. 1999.

JANNUZZI, Paulo de Martino. Estratificação socioocupacional para estudos de mercado e pesquisa social no Brasil. São Paulo em perspectiva, v. 17, n. 3-4, p. 247-254, 2003.

JENKINS, William Ieuan. Policy analysis: A political and organizational perspective. London: Martin Robertson, 1978.

JOHNSON, Nevil. Government in the Federal Republic of Germany: the executive at work. New York: Pergamon Press, 1973.

KAISER, Henry F. An index of factorial simplicity. Psychometrika, v. 39, n. 1, p. 31-36, 1974. 
KAMEL, Ali. Não somos racistas. Rio de Janeiro: Editora Nova Fronteira, 2006.

KEISER, Lael R. et al. Lipstick and logarithms: Gender, institutional context, and representative bureaucracy. American Political Science Review, v. 96, n. 03, p. 553-564, 2002.

KINDER, Donald R.; WINTER, Nicholas. Exploring the racial divide: Blacks, whites, and opinion on national policy. American Journal of Political Science, p. 439-456, 2001.

KINGDON, John W. Agendas, alternatives, and public policies. $2^{\mathrm{a}}$. ed. New York: Longman Classics in Political Science, 1995.

KINGSLEY, John Donald. Representative bureaucracy: An interpretation of the British civil service. California: Antioch Press Yellow Springs, OH, 1944.

LASSWELL, Harold. Política quem ganha o que, quando, como. Brasília: Universidade de Brasilia, 1984.

LAVILLE, Christian; DIONNE, Jean. A construção do saber: manual de metodologia da pesquisa em ciências humanas. Belo Horizonte: Editora UFMG, 1999.

LEITE, Marcia de Paula; SOUZA, Silvana Maria de. Igualdade de Gênero e Raça no Brasil: Uma Discussão sobre a Política Pública de Emprego. Dados-Revista de Ciências Sociais, v. 53, n. 1, p. 195-231, 2010.

LEWIS, David E. The politics of presidential appointments: Political control and bureaucratic performance. New Jersey: Princeton University Press, 2008.

LIMA, Maria Regina Soares de; CHEIBUB, Zairo Borges. Instituições e valores: As dimensões da democracia na visão da elite brasileira. Revista Brasileira de Ciências Sociais, São Paulo, 1996. , p. 83-110.

LINDBLOM, Charles E. O processo de decisão política. Brasília: Universidade de Brasília, 1980.

LOUREIRO, Maria Rita; ABRUCIO, Fernando Luiz. Política e burocracia no presidencialismo brasileiro: o papel do Ministério da Fazenda no primeiro governo Fernando Henrique Cardoso. Revista Brasileira de Ciências Sociais, v. 14, n. 41, p. 69-89, 1999.

LOUREIRO, Maria Rita Garcia; ABRUCIO, Fernando Luiz; PACHECO, Regina Silvia (Org.). Burocracia e política no Brasil: desafios para a ordem democrática no século XXI. Rio de Janeiro: FGV Editora, 2010a.

LOUREIRO, Maria Rita Garcia; OLIVIERI, Cecília; MARTES, Ana Cristina Braga. Burocratas, partidos e grupos de interesse: o debate sobre política e burocracia no Brasil. In: LOUREIRO, Maria Rita Garcia; ABRUCIO, Fernando Luiz; PACHECO, Regina Silvia (Org.). Burocracia e política no Brasil: desafios para a ordem democrática no século XXI. Rio de Janeiro: FGV Editora, 2010b. p. 73-108. 
MAGGIE, Yvonne. Aqueles a quem foi negada a cor do dia: as categorias cor e raça na cultura brasileira. In: MAIO, MARCOS C.; SANTOS, RICARDO V. (Org.). Raça, ciência e sociedade. Rio de Janeiro: Editora Fiocruz, 1996. p. 225-34.

MAGGIE, Yvonne. Em breve um país dividido? O Brasil do século XXI e as novas políticas públicas com base na" raça”. Perifèria. Revista d'investigació i formació en Antropologia, n. 5, 2009.

MAGGIE, Yvonne; FRY, Peter. A reserva de vagas para negros nas universidades brasileiras. Estudos Avançados, v. 18, n. 50, p. 67-80, 2004.

MARTELETO, Letícia Junqueira; VERONA, Ana Paula de Andrade; RODRIGUES, Cristina Guimarães. Raça e origem social: o papel das características do pai versus da mãe e da classificação racial na escolaridade. Desigualdades sociais, redes de sociabilidade $e$ participação política, p. 139-163, 2007.

MARTINS, Luciano. Estado capitalista e burocracia no Brasil pós-64. Rio de Janeiro: Paz e Terra Rio de Janeiro, 1985. v. 82.

MARTINS, Sérgio da Silva. Direito e combate à discriminação racial no Brasil. In: GUIMARÃES, ANTONIO SÉRGIO ALFREDO; HUNTLEY, LYNN (Org.). Tirando a máscara: ensaios sobre o racismo no Brasil. São Paulo: Paz e Terra, 2000. p. 411-434.

MATIAS-PEREIRA, José. Administração pública no Brasil: políticas de revalorização das carreiras típicas de Estado como fator de atração de novos talentos para o serviço público federal. 2004.

MEIER, Kenneth John. Representative bureaucracy: An empirical analysis. The American Political Science Review, v. 69, n. 2, p. 526-542, 1975.

MEIER, Kenneth John; NIGRO, Lloyd G. Representative bureaucracy and policy preferences: a study in the attitudes of federal executives. Public Administration Review, v. 36, n. 4, p. 458-469, ago. 1976.

MEIER, Kenneth J.; WRINKLE, Robert D.; POLINARD, Jerry L. Representative bureaucracy and distributional equity: addressing the hard question. The Journal of Politics, v. 61, n. 04, p. 1025-1039, 1999.

MOEHLECKE, Sabrina. Ação afirmativa: história e debates no Brasil. Cadernos de pesquisa, v. 117, p. 197-217, 2002.

MONTEIRO, Jorge Vianna. Fundamentos da política pública. Rio de Janeiro: Ipea/INPES, 1982.

MOSCA, Gaetano. The ruling class (Elementi di scienza politica). New York; London: McGraw-Hill Book Company, inc., 1939.

MOSHER, Frederick Camp. Democracy and the public service. New York: Oxford University Press, 1968. v. 53. 
MOTTA, Paulo Roberto; BANDEIRA, Mariana Lima. Responsabilidade pública: os reflexos da diversidade ética na gestão pública. In: VIII CONGRESO INTERNACIONAL DEL CLAD SOBRE LA REFORMA DEL ESTADO Y DE LA ADMINISTRACIÓN PÚBLICA, 28 out. 2003, Panamá. Anais. Panamá: [s.n.], 28 out. 2003.

MOURA, Cristina Patriota de. O Instituto Rio Branco e a diplomacia brasileira: um estudo de carreira e socialização. Rio de Janeiro: Editora FGV, 2007.

NAFF, Katherine C.; CRUM, John. The president and representative bureaucracy: Rhetoric and reality. Public Administration Review, v. 60, n. 2, p. 98-110, abr. 2000.

NASCIMENTO, Abdias. Quilombo: vida, problemas e aspirações do negro. dez.-1948.jul.-1950. ed. Rio de Janeiro: Editora 34, 2003. v. 1-10.

NASCIMENTO, Abdias; NASCIMENTO, Elisa Larkin. Reflexões sobre o movimento negro no Brasil, 1938-1997. In: GUIMARÃES, Antonio Sérgio Alfredo; HUNTLEY, Lynn (Org.). Tirando a Máscara: ensaios sobre o racismo no Brasil. São Paulo: Paz e Terra, 2000. p. 203-235.

NORVELL, John M. A brancura desconfortável das camadas médias brasileiras. Raça como retórica: a construção da diferença. Rio de Janeiro: Civilização Brasileira, 2001. p. 245267.

NUNES, Edson. A gramática política do Brasil: clientelismo e insulamento burocrático. $3^{\mathrm{a}}$. ed. Rio de Janeiro: Jorge Zahar Editor Ltda, 2003.

OFFE, Claus; FREITAG, Barbara. Problemas estruturais do Estado capitalista. Rio de Janeiro: Tempo Brasileiro Rio de Janeiro, 1984.

OGMUNDSON, Richard L. Does it matter if women, minorities and gays govern? New data concerning an old question. The Canadian Journal of Sociology, v. 30, n. 3, p. 315-324, 2005.

OLIVEIRA, Dijaci David. Perfil dos gestores das políticas de promoção da igualdade racial no Brasil. In: DAL ROSSO, SADI (Org.). Políticas de promoção da igualdade racial no Brasil: o papel da SEPPIR. Goiânia: FUNAPE, 2009. p. 19-41.

OLIVEIRA, Nelson do Vale. $O$ amadorismo como traço distintivo da burocracia federal brasileira. 2009. Tese de doutorado - Universidade de Brasília, Brasília, 2009.

OMI, Michael. Racial Formation in the United States: From the 1960s to the 1990s. [S.1.]: Psychology Press, 1994.

OSÓRIO, Rafael Guerreiro. A desigualdade racial de renda no Brasil: 1976-2006. 2009. Tese de doutorado - Universidade de Brasília, Brasília, 2009.

OSORIO, Rafael Guerreiro. Desigualdades raciais e de gênero no serviço público civil. Brasília: Secretaria Internacional do Trabalho, 2006. 
OSORIO, Rafael Guerreiro. O sistema classificatório de " cor ou raça” do IBGE. Brasília: Ipea, 2003.

PACHECO, Regina. Profissionalização, mérito e proteção da burocracia no Brasil. Burocracia e Política no Brasil: Desafio da Ordem Democrática no Século XXI. $1^{\text {a }}$. ed. Rio de Janeiro: FGV Editora, 2010. p. 277-305.

PASQUALI, Luiz. Análise fatorial para pesquisadores. Brasília: LabPAM, 2012.

PASTORE, José. Desigualdade e mobilidade social no Brasil. São Paulo: TA Queiroz Editor, 1979. v. 1.

PASTORE, José; SILVA, Nelson do Valle. Mobilidade social no Brasil. São Paulo: Makron Books, 2000.

PAULA, Marilene de. Políticas de ação afirmativa para negros no governo Fernando Henrique Cardoso (1995-2002). 2010. Tese de doutorado - Fundação Getulio Vargas, Rio de Janeiro, 2010.

PETRUCCI, Vera Lucia; BRITO, Marcelo; CASTRO SANTOS, Maria Helena De. Escolas de governo e profissionalização do funcionalismo. Brasília: Centro de Documentação, Informação e Difusão Graciliano Ramos, 1995.

PINTO, Celi RJ. Nota sobre a controvérsia Fraser-Honneth informada pelo cenário brasileiro. Lua Nova, v. 74, n. 74, p. 35-58, 2008.

PRZEWORSKY, Adam. Capitalism and social democracy. [S.1.]: Cambridge University Press, 1985.

PRZEWORSKY, Adam. Estado e economia no capitalismo. Rio de Janeiro: RelumeDumará, 1995.

QUIJANO, Aníbal. Colonialidad del poder, eurocentrismo y América Latina. Argentina: Clacso, 2000.2 Disponível em: $<$ http://ecaths1.s3.amazonaws.com/antropologiaslatinoamericanas/1161337413.AnibalQuijano.pdf>. Acesso em: 3 out. 2013.

REHFUSS, John A. A representative bureaucracy? Women and minority executives in California career service. Public Administration Review, p. 454-460, 1986.

REIS, Elisa. Perception of porverty and inequality among Brazilian Elites. In: MOORE, MICK; REIS, ELISA (Org.). Elite perceptions of poverty and inequality. New York: Zed Books, 2005.

ROCHA PINTO, Paulo. Ação afirmativa, fronteiras raciais e identidades acadêmicas. In: JÚNIOR, JOÃO FERES; ZONINSEIN, JONAS (Org.). Ação afirmativa e universidade: experiências nacionais comparadas. Brasília: Editora Universidade de Brasília, 2006. p. 9 45. 
ROUANET, Sérgio Paulo. Criação no Brasil de uma escola superior de administração pública. Brasília: Enap, 2005.

SANSONE, Livio. Nem somente preto ou negro: o sistema de classificação racial no Brasil que muda. Afro-Ásia, v. 18, p. 165-187, 1996.

SANTOS, Ivair Augusto Alves dos. O movimento negro e o Estado: o caso do Conselho de Participação e Desenvolvimento da Comunidade Negra no governo de São Paulo (19831987). 2001. Dissertação de mestrado - Universidade de Campinas, Campinas, 2001.

SANTOS, Luiz Alberto dos; CARDOSO, Regina Luna Santos. Carreiras de Executivos Públicos e o Ciclo de Políticas Públicas: A experiência dos Gestores Governamentais no Governo Federal do Brasil. In: V CONGRESSO INTERNACIONAL DO CENTRO LATINO-AMERICANO DE ADMINISTRAÇÃO PARA O DESENVOLVIMENTO CLAD, 2000, Santo Domingo. Anais. Santo Domingo: [s.n.], 2000.

SANTOS, Hélio. Discriminação racial no Brasil. Anais. Brasília: Ministério da Justiça, 2001.

SANTOS, Hélio. Políticas públicas para a população negra no Brasil. Observatório da cidadania, v. 3, 1999.

SANTOS, José Alcides Figueiredo. Efeitos de classe na desigualdade racial no Brasil. Dados, v. 48, n. 1, p. 21-65, 2005.

SANTOS, Sales Augusto dos. Movimentos negros, educação e ações afirmativas. 2009. Tese de doutorado - Universidade de Brasília, Brasília, 2009.

SCHNEIDER, Ben Ross. Burocracia pública e política industrial no Brasil. São Paulo: Editora Sumaré, 1994.

SCHUCMAN, Lia Vainer. Sim, nós somos racistas: estudo psicossocial da branquitude paulistana. Psicol. soc.(Online), v. 26, n. 1, p. 83-94, 2014.

SCHWARCZ, Lilia K. Moritz; MICELI, Sérgio. Questão racial e etnicidade. O que ler na ciência social brasileira (1970-1995), v. 1, p. 267-325, 1999.

SILVA, Nelson do Valle. Posição social das ocupações. Rio de Janeiro: IBGE, Centro de Informática, 1973.

SILVA, Tatiana et al. Planejamento e financiamento das políticas de igualdade racial: possibilidades para o Plano Plurianual 2012-2015. Relatório de pesquisa sobre igualdade racial, $\mathrm{n}^{\circ}$ 7. Brasília: Ipea, 2011.

SILVEIRA, Marly; SANTOS, Sales Augusto Dos. Políticas de promoção da igualdade racial e ação afirmativa. 2010.2 Disponível em: <http://aplicacao.tst.jus.br/dspace/handle/1939/19700>. Acesso em: 28 ago. 2012.

SIMÕES, Solange; JERONYMO, Mauro Quem é negro no Brasil? Identidade racial e sistemas de classificação em uma sociedade miscigenada. In: AGUIAR, Neuma (Org.). Desigualdades sociais, redes de sociabilidade e participação política, p. 119-138, 2007. 
SIMÕES, Solange; PEREIRA, Maria Aparecida Machado. A arte e a ciência de fazer perguntas. In: AGUIAR, NEUMA (Org.). Desigualdades sociais, redes de sociabilidade e participação política. Belo Horizonte: Editora UFMG, 2007. p. 241-261.

SKIDMORE, Thomas E. Preto no Branco: raça e nacionalidade no pensamento brasileiro (1870-1930). São Paulo: Companhia das Letras, 2012.

SOARES, Sergei. A demogracia da cor: a composição da população brasileira de 1890 a 2007 - Google Acadêmico. In: THEODORO, MÁRIO (Org.). As políticas públicas e a desigualdade racial no Brasil: 120 anos após a abolição. Brasília: Ipea, 2008.

SOUZA, Eda Castro Lucas De. A capacitação administrativa e a formação de gestores governamentais. Revista de administração pública, v. 36, n. 1, p. 73-88, 2002.

SOUZA, Pedro; MEDEIROS, Marcelo. Diferencial salarial público-privado e desigualdade de renda per capita no Brasil. Estudos Econômicos (São Paulo), v. 43, n. 1, p. 05-28, 2013.

SOWELL, Thomas. Affirmative action around the world: an empirical study. [S.1.]: Yale University Press, 2004.

STEINBUGLER, Amy C.; PRESS, Julie E.; DIAS, Janice Johnson. Gender, race, and affirmative action operationalizing intersectionality in survey research. Gender \& Society, v. 20, n. 6 , p. $805-825,2006$.

STOLCKE, Verena. ¿ Es el sexo para el género lo que la raza para la etnicidad... y la naturaleza para la sociedad? Política y cultura, n. 014, p. 25-60, 2000.

SUPREMO TRIBUNAL FEDERAL. Arguição de Descumprimento de Preceito Fundamental (Medida Liminar)-ADPF 186. Brasília: Supremo Tribunal Federal, 2009. Disponível

em: <http://www.stf.jus.br/arquivo/cms/noticiaNoticiaStf/anexo/ADPF186RL.pdf $>$ Acesso em: 7 fev. 2014.

TELLES, Edward. Racismo à brasileira: uma nova perspectiva sociológica. Rio de Janeiro: Relume Dumará, 2003.

TELLES, Edward; BAILEY, Stan. Políticas contra o racismo e opinião pública: comparações entre Brasil e Estados Unidos. Opinião Pública, v. 8, n. 1, p. 30-39, 2002.

THEOBALD, Nick A.; HAIDER-MARKEL, Donald P. Race, bureaucracy, and symbolic representation: Interactions between citizens and police. Journal of Public Administration Research and Theory, v. 19, n. 2, p. 409-426, 2009.

THEODORO, Mário. À guisa de conclusão: o difícil debate da questão racial e das políticas públicas de combate à desigualdade e à discriminação racial no Brasil. As políticas públicas e a desigualdade racial no Brasil: 120 anos após a abolição. Brasília: Ipea, 2008.

THEODORO, Mário et al. As políticas públicas e a desigualdade racial no Brasil: 120 anos após a abolição. Rio de Janeiro: Ipea, 2008. 
THOMPSON, Frank J. Civil servants and the deprived: Socio-political and occupational explanations of attitudes toward minority hiring. American Journal of Political Science, v. 22, n. 2, p. 325-347, maio 1978.

TONETO JR, Rudinei. Buchanan e a análise econômica da política. Lua Nova: Revista de Cultura e Política, n. 38, p. 125-145, 1996.

TREIMAN, Donald J. Occupational prestige in comparative perspective. New York: Academic Press, 1977.

VAN DE WALLE, Steven; GROENEVELD, Sandra; VANDENBUSSCHE, Lieselot. Representative Bureaucracy in Belgium: Power-Sharing or Diversity? In: VON MARAVIC, Patrick; PETERS, B.Guy; SCHRÖTER, Eckard (Org.). . Representative bureaucracy in action: country profiles from the Americas, Europe, Africa, and Asia. Cheltenham: Edward Elgar Publishing, 2013. p. 69-86.

VAZ, Tania Patricia de Lara. O papel da advocacia de Estado na gestão pública: análise da política pública energética no Brasil. 2010. Dissertação de mestrado - Instituto Universitário de Lisboa, Lisboa, 2010.

VIOTTI DA COSTA, Emilia. The myth of racial democracy: a legacy of the empire. The Brazilian Empire: myths and histories (Chicago, 1985), p. 234-46, 1985.

WEBER, Max. A política como vocação. Max Weber-Ensaios de Sociologia. 2a . ed. Rio de Janeiro: Zahar Editores, 1971. p. 97-153.

WEBER, Max. Economia e sociedade 2. São Paulo: Imprensa Oficial, 1999.

WEBER, Max. Parlamento e governo na Alemanha reordenada: crítica política da burocracia e da natureza dos partidos. Petrópolis, RJ: Editora Vozes, 1993. (Clássicos do Pensamento Político).

WINN, Mylon. Black administrators and racial road blocks in public organizations: problems and recourse. International Journal of Public Administration, v. 12, n. 5, p. 797$819,1989$.

WRIGHT, Erik Olin. Class counts: comparative studies in class analysis. Cambridge: Cambridge University Press, 1997.

WRIGHT, Erik Olin. Class, race and gender.Lecture Notes. University of California, Berkeley, 2002. Disponível em: <http://www.ssc.wisc.edu/ wright/298lectures.html>. Acesso em: 30 jan. 2014.

WRIGHT, Erik Olin. Comments on José Alcides Figueiredo Santos Paper. In: SEMINÁRIO DE PESQUISA DO PROGRAMA DE SOCIOLOGIA ECONÔMICA DO DEPARTAMENTO DE SOCIOLOGIA, 27 set. 2004, Universidade de Wisconsin-Madison. Anais. Universidade de Wisconsin-Madison: [s.n.], 27 set. 2004.

WRIGHT, Erik Olin. Foundations of a neo-Marxist class analysis. Approaches to class analysis. Cambridge: Cambridge University Press, 2005. p. 4-30. 
WRIGHT, Erik Olin. Race, class, and income inequality. American Journal of Sociology, p. 1368-1397, 1978.

WRIGHT, Vincent. Politics and administration under the french Fifth Republic. Political Studies, v. 22, n. 1, p. 44-65, 1974.

WYATT, Nancy; PHILLIPS, Gerald M. A case study of the farmers home administration: Studying organizational communication. Norwood, NJ: Ablex Publishing Company, 1988. 


\section{Anexos}

\section{Anexo A}

Tabela A.1 - Cruzamento das variáveis Negros_CrecheEscola e Pobres_CrecheEscola (\%)

\begin{tabular}{|c|c|c|}
\hline \multicolumn{3}{|c|}{ Pobres_CrecheEscola } \\
\hline Concorda & $\begin{array}{c}\text { Não } \\
\text { conc.nem }\end{array}$ & Discorda \\
\hline
\end{tabular}

\begin{tabular}{|c|c|c|c|c|c|c|}
\hline \multirow{3}{*}{\multicolumn{2}{|c|}{$\underset{\substack{\mathrm{Z} \\
\sigma}}{\mathrm{Z}}$}} & Negros_CrecheEscola & 99,7 & 0 & 0,3 & 100 \\
\hline & & Pobres_CrecheEscola & 37,7 & 0 & 4,5 & 36,2 \\
\hline & & Total & 36,1 & 0 & 0,1 & 36,2 \\
\hline \multirow{6}{*}{ 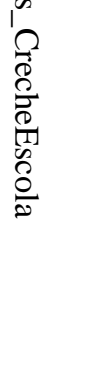 } & : & Negros_CrecheEscola & 92,7 & 6,5 & 0,8 & 100 \\
\hline & & Pobres_CrecheEscola & 14,1 & 50 & 4,5 & 14,5 \\
\hline & & Total & 13,5 & 0,9 & 0,1 & 14,5 \\
\hline & Discorda & Negros_CrecheEscola & 93,3 & 1,9 & 4,8 & 100 \\
\hline & & Pobres_CrecheEscola & 48,2 & 50 & 90,9 & 49,3 \\
\hline & & Total & 46,0 & 0,9 & 2,3 & 49,3 \\
\hline \multirow{3}{*}{\multicolumn{2}{|c|}{ Total }} & Negros_CrecheEscola & 95,6 & 1,9 & 2,6 & 100 \\
\hline & & Pobres_CrecheEscola & 100,0 & 100 & 100 & 100 \\
\hline & & Total & 95,6 & 1,9 & 2,6 & 100 \\
\hline
\end{tabular}

Fonte: Dados primários - Elaboração da própria autora, 2014

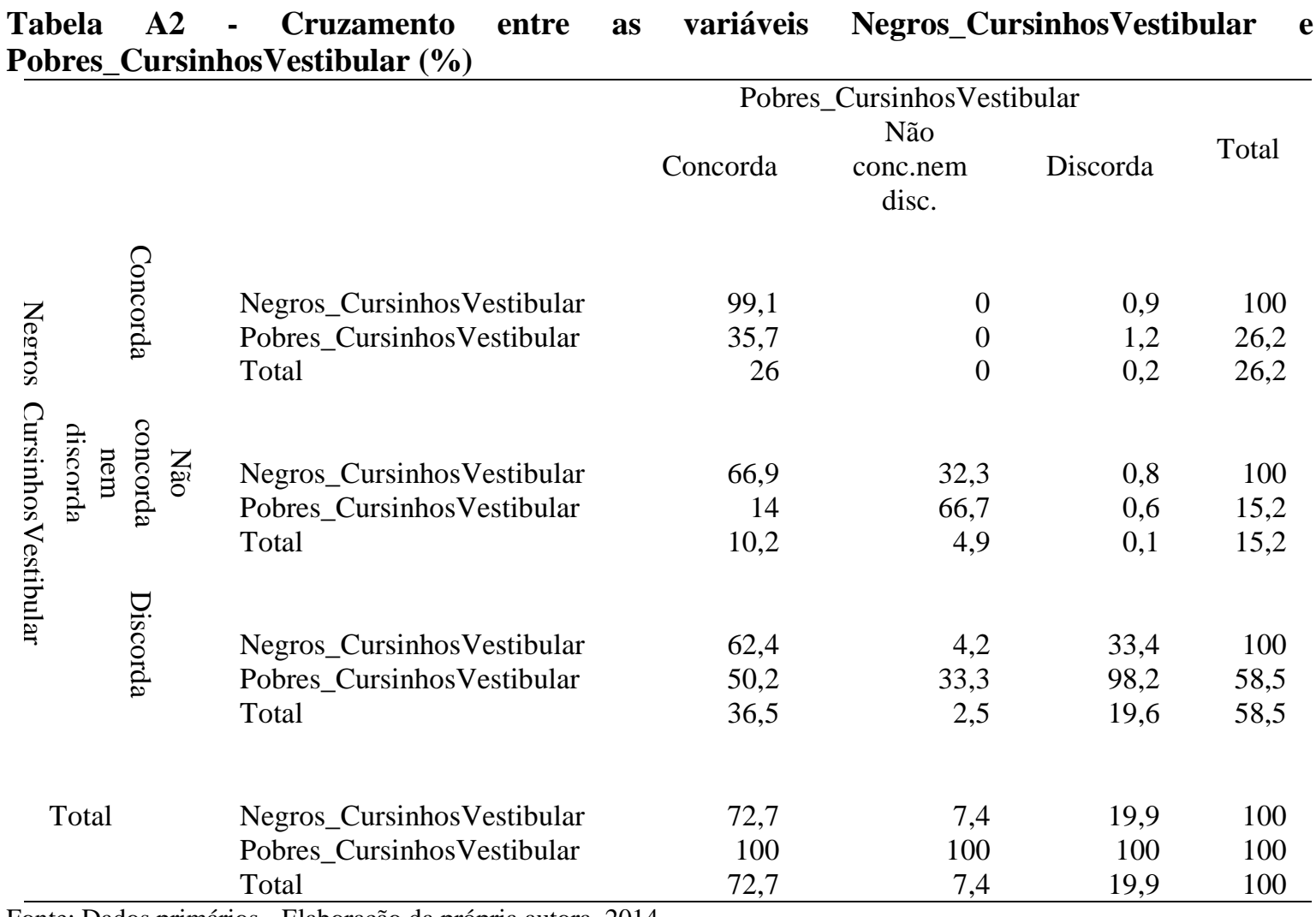

Fonte: Dados primários - Elaboração da própria autora, 2014 
Tabela A3 - Cruzamento entre as variáveis Negros_IESAcesso e Pobres_IEAcesso (\%)

\begin{tabular}{ccc}
\multicolumn{3}{c}{ Pobres_IESAcesso } \\
Concorda & $\begin{array}{l}\text { Não conc. } \\
\text { nem disc. }\end{array} \quad$ Discorda & Total
\end{tabular}

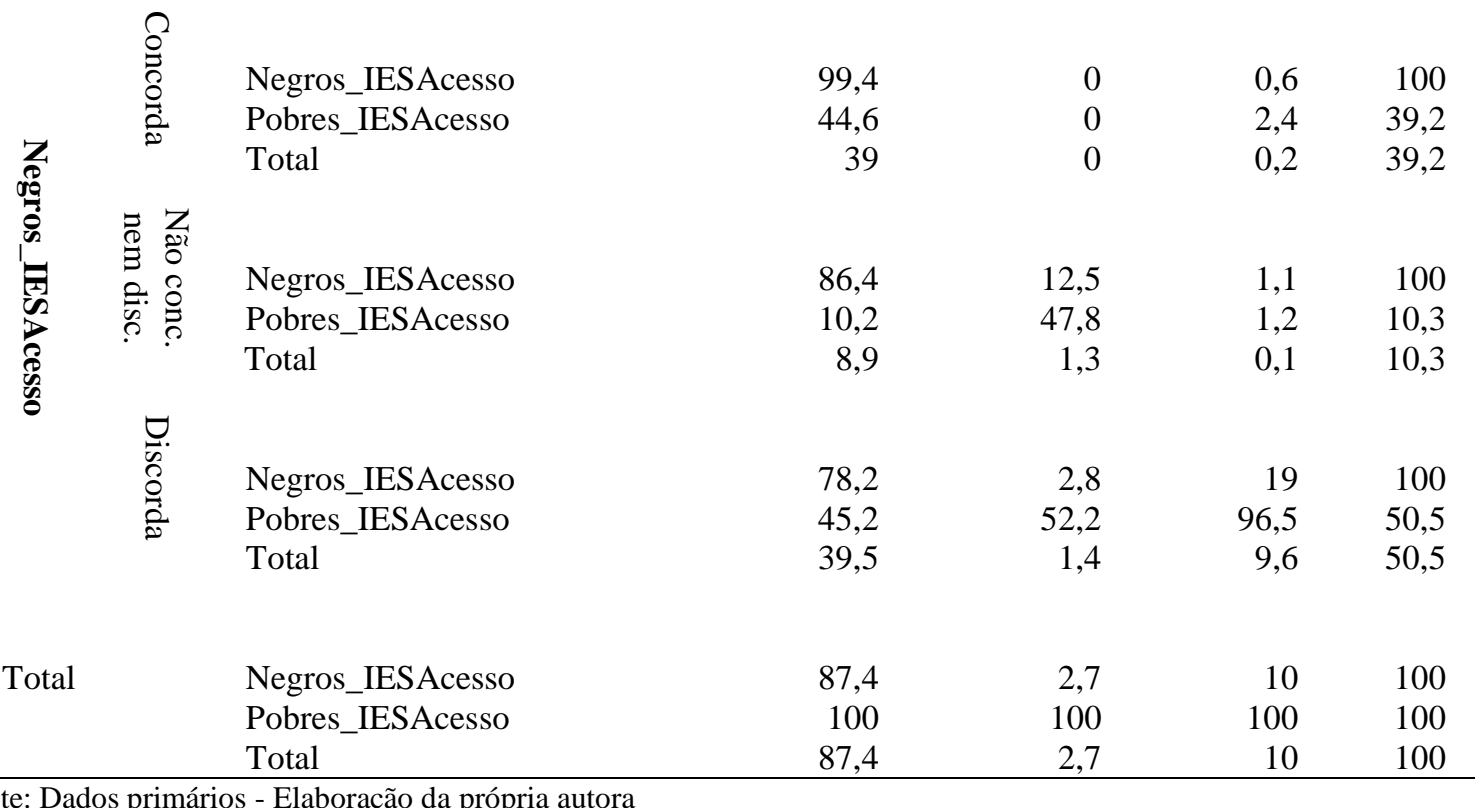

Fonte: Dados primários - Elaboração da própria autora

Tabela A4 - Cruzamento entre as variáveis Negros_UnidadesSaúde e Pobres_UnidadesSaúde (\%)

\begin{tabular}{ll}
\multicolumn{3}{c}{ Pobres_UnidadesSaúde } \\
Concorda & $\begin{array}{l}\text { Não conc. } \\
\text { nem disc. }\end{array} \quad$ Discorda
\end{tabular}$\quad$ Total

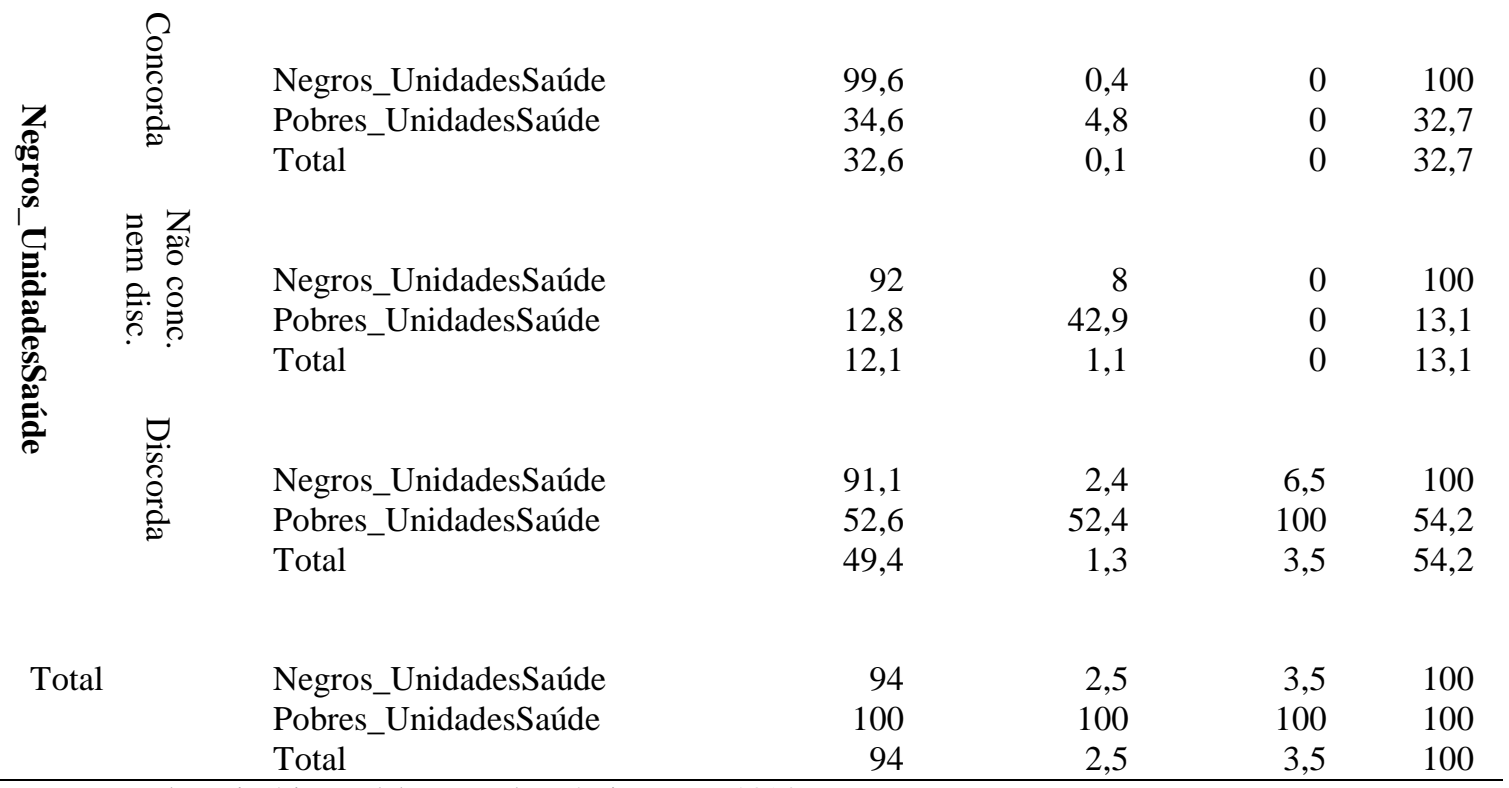

Fonte: Dados primários - Elaboração da própria autora, 2014 
Tabela A5 - Cruzamento entre as variáveis Negros_FábricasÁreas e Pobres_FábricaÁreas (\%) $\begin{array}{cc}\text { Pobres_FábricaÁreas } \\ \text { Concorda } & \begin{array}{l}\text { Não conc. Discorda } \\ \text { nem disc. }\end{array}\end{array}$

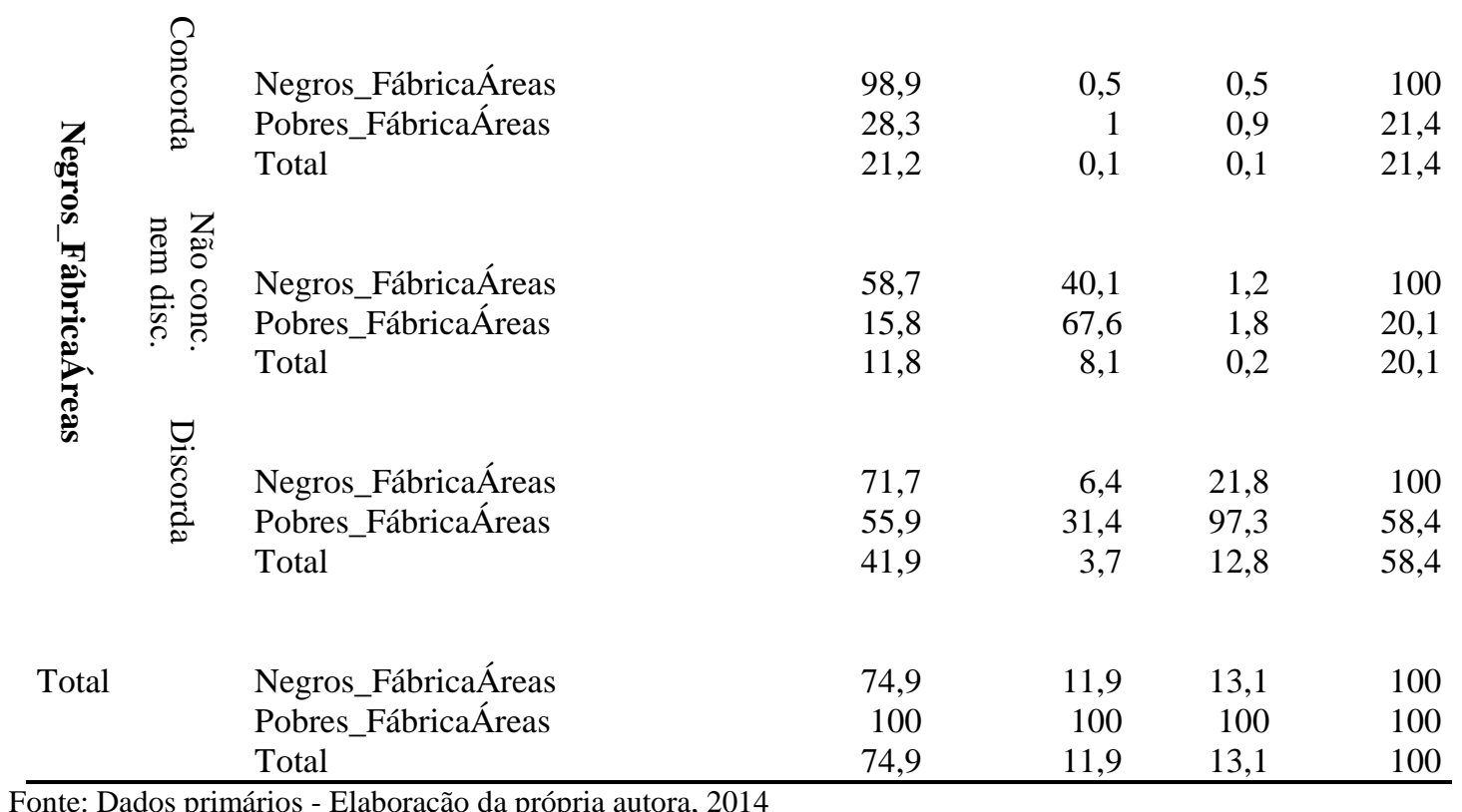

Tabela A6 - Cruzamento entre as variáveis Negros_ConcursoPúblico e Pobres_ConcursoPúblico (\%)

\begin{tabular}{|c|c|c|c|}
\hline \multicolumn{3}{|c|}{ Pobres_ConcursoPúblico } & \multirow{3}{*}{ Total } \\
\hline & $\begin{array}{l}\text { Não } \\
\text { conc nem }\end{array}$ & Discorda & \\
\hline & $\begin{array}{l}\text { disc. } \\
\text { dist }\end{array}$ & & \\
\hline
\end{tabular}

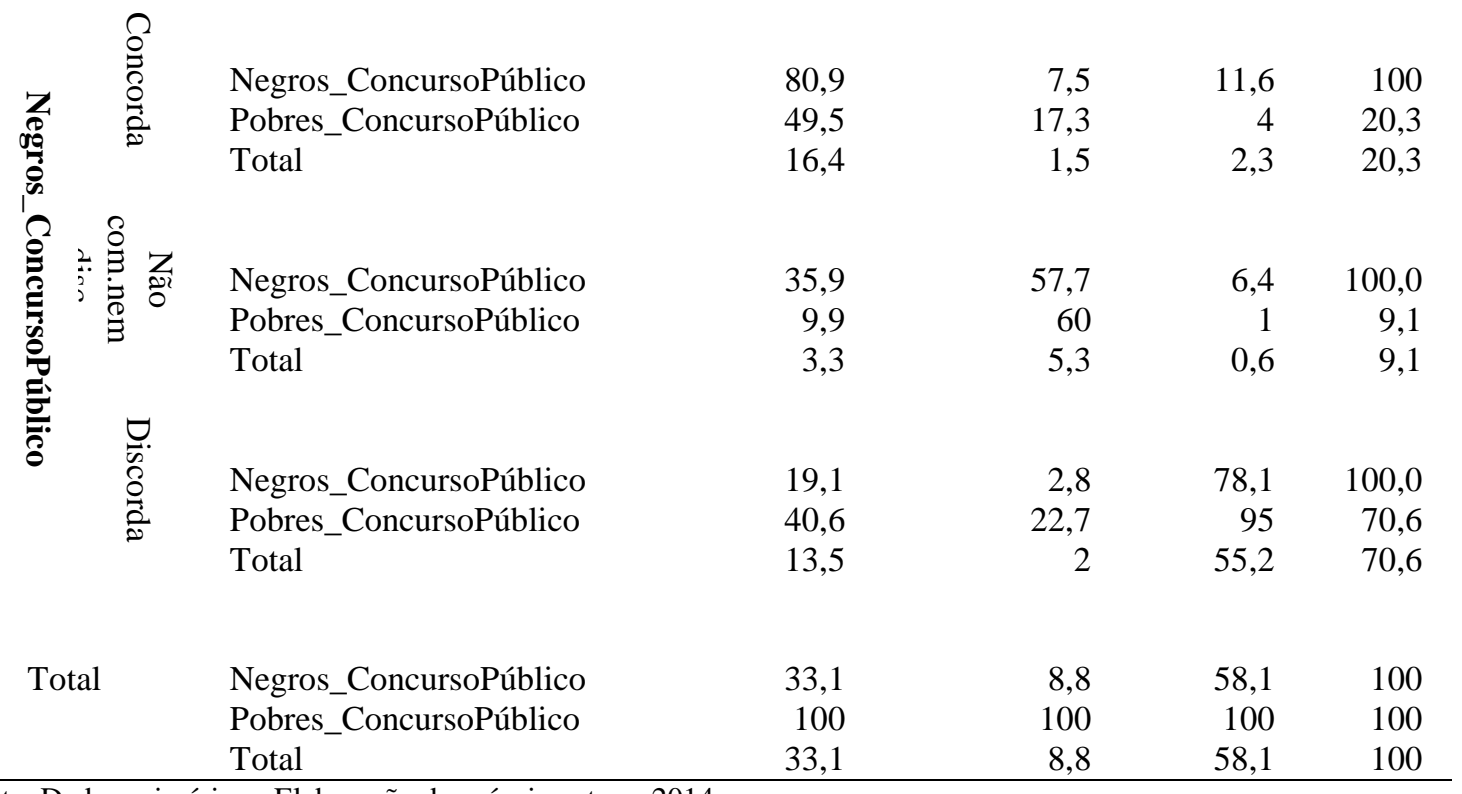

Fonte: Dados primários - Elaboração da própria autora, 2014 
Tabela A7 - Coeficientes estimados da influência de variáveis em relação às políticas de promoção da igualdade racial para população negra de acordo com diferentes modelos de Regressão Múltipla Linear.

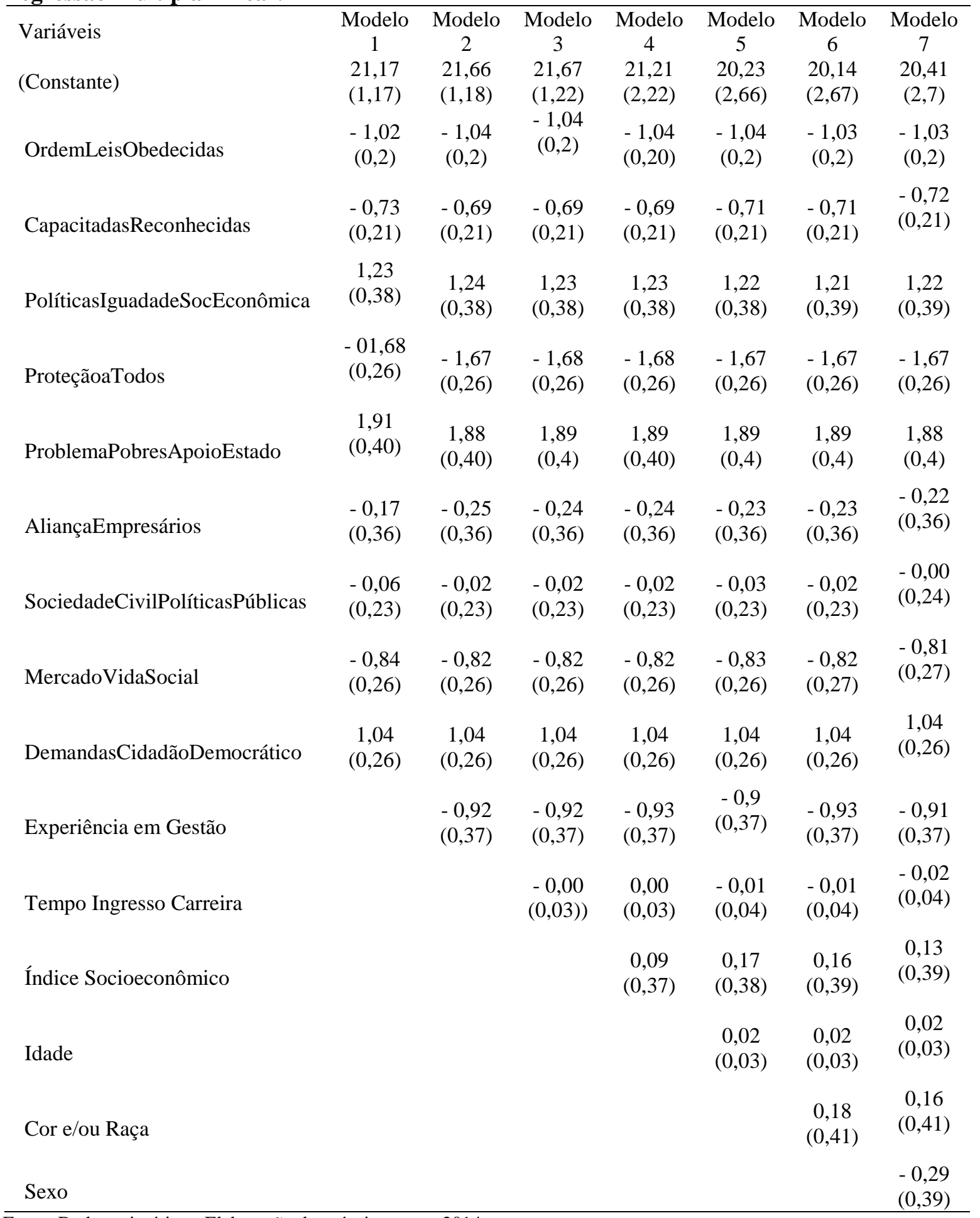

Fonte: Dados primários - Elaboração da própria autora, 2014

Nota: Coeficientes de regressão com erros padrões (entre parênteses) 


\begin{tabular}{|c|c|c|c|c|c|c|}
\hline \multirow[b]{2}{*}{ Ocupação } & \multicolumn{4}{|c|}{ Carreiras } & \multirow[b]{2}{*}{$\begin{array}{l}\text { TPP- } \\
\text { Ipea }\end{array}$} & \multirow[b]{2}{*}{ Total } \\
\hline & Adv.União & APO & EPPGG & Procurador & & \\
\hline Açougueiro & 1 & 1 & 0 & 0 & 0 & 2 \\
\hline Administrador & 4 & 1 & 14 & 13 & 2 & 34 \\
\hline Advogado & 19 & 6 & 7 & 30 & 2 & 64 \\
\hline Agricultor & 12 & 2 & 8 & 15 & 1 & 38 \\
\hline Agrimensor & 0 & 0 & 0 & 1 & 0 & 1 \\
\hline Agrônomo & 0 & 1 & 1 & 0 & 0 & 2 \\
\hline $\begin{array}{l}\text { Ajudante de serviços } \\
\text { gerais }\end{array}$ & 0 & 0 & 1 & 0 & 0 & 1 \\
\hline Alfaiate & 0 & 0 & 0 & 1 & 0 & 1 \\
\hline Analista de Sistemas & 1 & 0 & 2 & 1 & 0 & 4 \\
\hline Antropólogo & 0 & 0 & 1 & 0 & 0 & 1 \\
\hline Arquiteto & 1 & 0 & 1 & 0 & 0 & 2 \\
\hline Artesão & 1 & 0 & 0 & 0 & 1 & 2 \\
\hline Artista Plástico & 1 & 0 & 0 & 0 & 0 & 1 \\
\hline Assistente & 0 & 0 & 1 & 0 & 0 & 1 \\
\hline $\begin{array}{l}\text { Auditor Fiscal da } \\
\text { Receita Federal }\end{array}$ & 1 & 1 & 0 & 2 & 0 & 4 \\
\hline Auxiliar de Escritório & 0 & 0 & 1 & 0 & 0 & 1 \\
\hline Bancário & 9 & 3 & 13 & 18 & 1 & 44 \\
\hline Barbeiro & 1 & 0 & 0 & 0 & 0 & 1 \\
\hline Biólogo & 0 & 0 & 1 & 0 & 0 & 1 \\
\hline Caminhoneiro & 5 & 0 & 1 & 0 & 0 & 6 \\
\hline Carpinteiro & 1 & 1 & 0 & 1 & 0 & 3 \\
\hline Carroceiro & 0 & 0 & 1 & 0 & 0 & 1 \\
\hline Cientista Político & 0 & 0 & 1 & 0 & 0 & 1 \\
\hline Cobrador de ônibus & 0 & 1 & 0 & 0 & 0 & 1 \\
\hline Comerciante & 11 & 7 & 24 & 23 & 7 & 72 \\
\hline Comerciário & 3 & 2 & 2 & 10 & 0 & 17 \\
\hline Conferente & 0 & 0 & 0 & 1 & 0 & 1 \\
\hline Consultor & 1 & 0 & 0 & 0 & 0 & 1 \\
\hline Contador & 4 & 2 & 7 & 8 & 2 & 23 \\
\hline Corretor de Imóveis & 0 & 0 & 0 & 3 & 1 & 4 \\
\hline Corretor de Seguros & 0 & 0 & 0 & 1 & 0 & 1 \\
\hline Delegado & 1 & 0 & 0 & 3 & 0 & 4 \\
\hline Dentista & 0 & 1 & 3 & 2 & 2 & 8 \\
\hline Desembargador & 0 & 0 & 0 & 1 & 0 & 1 \\
\hline Desenhista industrial & 0 & 0 & 0 & 1 & 0 & 1 \\
\hline Diplomata & 0 & 0 & 1 & 0 & 0 & 1 \\
\hline
\end{tabular}




\begin{tabular}{|c|c|c|c|c|c|c|}
\hline \multicolumn{7}{|c|}{ Carreiras } \\
\hline Ocupações & & & EPPGG & Procurador & $\begin{array}{l}\text { TPP- } \\
\text { Ipea }\end{array}$ & Total \\
\hline Economista & 9 & 4 & 9 & 4 & 1 & 27 \\
\hline Eletricista & 3 & 0 & 0 & 0 & 0 & 3 \\
\hline Eletrotécnico & 1 & 0 & 1 & 2 & 0 & 4 \\
\hline Empresário & 9 & 1 & 7 & 11 & 1 & 29 \\
\hline Enfermeiro & 0 & 0 & 1 & 0 & 0 & 1 \\
\hline Engenheiro & 11 & 11 & 27 & 32 & 3 & 84 \\
\hline Escrivão de Polícia & 0 & 0 & 0 & 1 & 0 & 1 \\
\hline Estatístico & 1 & 1 & 0 & 0 & 0 & 2 \\
\hline Estofador & 0 & 0 & 0 & 1 & 0 & 1 \\
\hline Farmacêutico & 1 & 0 & 1 & 1 & 0 & 3 \\
\hline Fazendeiro & 1 & 0 & 1 & 2 & 1 & 5 \\
\hline Fiscal de Obras & 2 & 0 & 1 & 0 & 0 & 3 \\
\hline Fiscal de Rendas & 0 & 0 & 0 & 2 & 0 & 2 \\
\hline Físico & 0 & 0 & 1 & 1 & 0 & 2 \\
\hline Geólogo & 0 & 1 & 0 & 0 & 0 & 1 \\
\hline Gráfico & 0 & 0 & 0 & 1 & 0 & 1 \\
\hline Historiador & 1 & 0 & 0 & 0 & 0 & 1 \\
\hline Hoteleiro & 0 & 0 & 0 & 1 & 0 & 1 \\
\hline Industriário & 1 & 0 & 2 & 1 & 0 & 4 \\
\hline Jornalista & 0 & 0 & 9 & 2 & 0 & 11 \\
\hline Juiz de Direito & 1 & 0 & 2 & 2 & 0 & 5 \\
\hline Maestro & 0 & 0 & 1 & 0 & 0 & 1 \\
\hline $\begin{array}{l}\text { Maquinista } \\
\text { Ferroviário }\end{array}$ & 0 & 0 & 1 & 1 & 0 & 2 \\
\hline Marceneiro & 0 & 1 & 0 & 0 & 0 & 1 \\
\hline Matemático & 0 & 0 & 0 & 1 & 0 & 1 \\
\hline Mecânico & 0 & 1 & 2 & 2 & 1 & 6 \\
\hline Médico & 13 & 4 & 12 & 16 & 2 & 47 \\
\hline Mestre de Obras & 0 & 0 & 0 & 2 & 0 & 2 \\
\hline Metalúrgico & 0 & 1 & 0 & 1 & 0 & 2 \\
\hline Militar & 4 & 3 & 6 & 16 & 3 & 32 \\
\hline Motorista & 2 & 2 & 6 & 5 & 0 & 15 \\
\hline Músico & 0 & 0 & 0 & 1 & 0 & 1 \\
\hline $\begin{array}{l}\text { Operador de } \\
\text { Computador }\end{array}$ & 1 & 1 & 0 & 0 & 0 & 2 \\
\hline Operário & 1 & 0 & 1 & 1 & 0 & 3 \\
\hline Pedreiro & 1 & 0 & 1 & 1 & 0 & 3 \\
\hline Pintor & 0 & 0 & 0 & 0 & 1 & 1 \\
\hline
\end{tabular}


(conclusão)

\begin{tabular}{|c|c|c|c|c|c|c|}
\hline \multicolumn{7}{|c|}{ Carreiras } \\
\hline Ocupação & Adv. União & APO & EPPGG & Procurador & $\begin{array}{l}\text { TPP- } \\
\text { Ipea }\end{array}$ & Total \\
\hline Policial & 0 & 0 & 1 & 5 & 1 & 7 \\
\hline Procurador de Estado & 2 & 0 & 1 & 2 & 0 & 5 \\
\hline Professor & 4 & 2 & 12 & 13 & 1 & 32 \\
\hline $\begin{array}{l}\text { Professor } \\
\text { Universitário }\end{array}$ & 4 & 0 & 4 & 6 & 0 & 14 \\
\hline Promotor de Justiça & 1 & 0 & 0 & 2 & 0 & 3 \\
\hline Protético & 1 & 0 & 1 & 0 & 0 & 2 \\
\hline Químico & 0 & 0 & 2 & 1 & 0 & 3 \\
\hline $\begin{array}{l}\text { Representante } \\
\text { Comercial }\end{array}$ & 3 & 1 & 1 & 1 & 0 & 6 \\
\hline Sapateiro & 0 & 0 & 1 & 0 & 0 & 1 \\
\hline Serralheiro & 1 & 0 & 0 & 1 & 1 & 3 \\
\hline $\begin{array}{l}\text { Servidor Público } \\
\text { Auxiliar }\end{array}$ & 2 & 1 & 1 & 4 & 0 & 8 \\
\hline $\begin{array}{l}\text { Servidor Público } \\
\text { Intermediário }\end{array}$ & 0 & 2 & 4 & 3 & 0 & 9 \\
\hline $\begin{array}{l}\text { Servidor Público } \\
\text { Superior }\end{array}$ & 7 & 7 & 31 & 27 & 1 & 73 \\
\hline Soldador & 0 & 0 & 1 & 0 & 0 & 1 \\
\hline Supervisor Técnico & 1 & 0 & 0 & 0 & 0 & 1 \\
\hline $\begin{array}{l}\text { TConstrução de } \\
\text { Estradas(Técnico) }\end{array}$ & 0 & 0 & 0 & 1 & 0 & 1 \\
\hline TécAgrícola & 1 & 0 & 0 & 0 & 0 & 1 \\
\hline TécnicMetalurgia & 0 & 0 & 1 & 1 & 0 & 2 \\
\hline $\begin{array}{l}\text { Técnico de } \\
\text { Contabilidade }\end{array}$ & 2 & 2 & 0 & 4 & 0 & 8 \\
\hline $\begin{array}{l}\text { Técnico de } \\
\text { Telecomunicações }\end{array}$ & 0 & 0 & 1 & 0 & 2 & 3 \\
\hline Técnico em Seguros & 0 & 0 & 0 & 1 & 0 & 1 \\
\hline Topógrafo & 1 & 0 & 0 & 0 & 0 & 1 \\
\hline Tradutor & 0 & 0 & 2 & 0 & 0 & 2 \\
\hline Veterinário & 1 & 0 & 0 & 2 & 0 & 3 \\
\hline Vigilante & 0 & 0 & 0 & 2 & 0 & 2 \\
\hline Zootecnista & 0 & 0 & 0 & 1 & 0 & 1 \\
\hline otal & 171 & 75 & 247 & 323 & 38 & 854 \\
\hline
\end{tabular}

Fonte: Dados primários - Elaboração da própria autora, 2014 


\begin{tabular}{|c|c|c|c|c|c|c|}
\hline \multirow[b]{2}{*}{ Ocupações } & \multicolumn{5}{|c|}{ Carreiras } & \multirow[b]{2}{*}{ Total } \\
\hline & $\begin{array}{l}\text { Adv. } \\
\text { União }\end{array}$ & APO & EPPGG & Procurador & $\begin{array}{l}\text { TPP- } \\
\text { Ipea }\end{array}$ & \\
\hline Administrador & 0 & 1 & 5 & 1 & 1 & 8 \\
\hline Advogado & 5 & 1 & 8 & 5 & 1 & 20 \\
\hline Agricultor & 3 & 1 & 2 & 6 & 0 & 12 \\
\hline Alfaiate & 5 & 2 & 7 & 2 & 1 & 17 \\
\hline Analista de Sistema & 0 & 0 & 0 & 1 & 0 & 1 \\
\hline Antropólogo & 0 & 0 & 1 & 0 & 0 & 1 \\
\hline Arquiteto & 1 & 0 & 2 & 2 & 0 & 5 \\
\hline Artesão & 2 & 0 & 0 & 0 & 0 & 2 \\
\hline Artista Plástico & 0 & 0 & 1 & 1 & 0 & 2 \\
\hline Assistente & 1 & 0 & 1 & 0 & 0 & 2 \\
\hline Assistente Social & 6 & 2 & 3 & 3 & 0 & 14 \\
\hline Auxiliar de Enfermagem & 0 & 1 & 0 & 2 & 1 & 4 \\
\hline Auxiliar de Escritório & 0 & 1 & 1 & 1 & 0 & 3 \\
\hline Bancária & 0 & 0 & 0 & 1 & 0 & 1 \\
\hline Bancário & 2 & 3 & 2 & 10 & 0 & 17 \\
\hline Bibliotecário & 1 & 1 & 1 & 3 & 1 & 7 \\
\hline Biólogo & 0 & 0 & 2 & 0 & 1 & 3 \\
\hline Cabeleireiro & 0 & 0 & 0 & 2 & 0 & 2 \\
\hline Cobrador de ônibus & 1 & 0 & 0 & 0 & 0 & 1 \\
\hline Comerciante & 3 & 2 & 5 & 9 & 3 & 22 \\
\hline Comerciário & 4 & 0 & 1 & 0 & 0 & 5 \\
\hline Contador & 0 & 1 & 0 & 1 & 0 & 2 \\
\hline Corretor de Imóveis & 1 & 0 & 1 & 3 & 0 & 5 \\
\hline Corretor de Seguros & 0 & 0 & 0 & 1 & 0 & 1 \\
\hline Dentista & 4 & 1 & 5 & 4 & 0 & 14 \\
\hline Doméstica & 3 & 3 & 6 & 10 & 0 & 22 \\
\hline Dona de Casa & 52 & 20 & 60 & 76 & 10 & 218 \\
\hline Economista & 3 & 1 & 2 & 3 & 0 & 9 \\
\hline Empresário & 1 & 1 & 6 & 7 & 0 & 15 \\
\hline Enfermeiro & 2 & 0 & 2 & 0 & 1 & 5 \\
\hline Engenheiro & 1 & 1 & 1 & 5 & 0 & 8 \\
\hline Escriturário & 0 & 0 & 0 & 3 & 0 & 3 \\
\hline Esteticista & 0 & 0 & 1 & 1 & 0 & 2 \\
\hline Farmacêutico & 0 & 0 & 0 & 1 & 0 & 1 \\
\hline Geógrafo & 0 & 0 & 1 & 0 & 0 & 1 \\
\hline Historiador & 0 & 1 & 1 & 0 & 0 & 2 \\
\hline Industriário & 0 & 1 & 0 & 0 & 0 & 1 \\
\hline
\end{tabular}




\begin{tabular}{|c|c|c|c|c|c|c|}
\hline \multicolumn{7}{|c|}{ Carreiras } \\
\hline Ocupações & $\begin{array}{l}\text { Adv. } \\
\text { União }\end{array}$ & APO & EPPGG & Procurador & $\begin{array}{l}\text { TPP- } \\
\text { Ipea }\end{array}$ & Total \\
\hline Instrumentador & 1 & 0 & 0 & 0 & 0 & 1 \\
\hline Jornalista & 1 & 1 & 3 & 2 & 0 & 7 \\
\hline Matemático & 0 & 0 & 0 & 1 & 0 & 1 \\
\hline Médico & 5 & 2 & 10 & 6 & 0 & 23 \\
\hline Nutricionista & 0 & 0 & 0 & 1 & 0 & 1 \\
\hline Paisagista & 1 & 0 & 0 & 0 & 0 & 1 \\
\hline Pedagogo & 6 & 2 & 3 & 6 & 1 & 18 \\
\hline Postalista & 0 & 0 & 0 & 1 & 0 & 1 \\
\hline Professor & 28 & 14 & 49 & 81 & 11 & 183 \\
\hline Professor Universitário & 3 & 0 & 4 & 4 & 0 & 11 \\
\hline Psicanalista & 1 & 0 & 0 & 0 & 0 & 1 \\
\hline Psicólogo & 5 & 1 & 4 & 6 & 0 & 16 \\
\hline Psicopedagogo & 0 & 0 & 0 & 0 & 1 & 1 \\
\hline Químico & 0 & 1 & 0 & 2 & 0 & 3 \\
\hline Secretário & 0 & 1 & 2 & 3 & 0 & 6 \\
\hline Servidor Público Auxiliar & 1 & 0 & 3 & 1 & 0 & 5 \\
\hline $\begin{array}{l}\text { Servidor Público } \\
\text { Intermediário }\end{array}$ & 5 & 1 & 11 & 4 & 0 & 21 \\
\hline Servidor Público Superior & 11 & 5 & 23 & 35 & 4 & 78 \\
\hline Sociólogo & 0 & 0 & 1 & 1 & 0 & 2 \\
\hline Teatrólogo & 0 & 0 & 0 & 1 & 0 & 1 \\
\hline TécnAdministrativo & 0 & 0 & 0 & 2 & 0 & 2 \\
\hline Técnico de Contabilidade & 1 & 2 & 3 & 2 & 1 & 9 \\
\hline TécnicoQuímica & 0 & 0 & 1 & 0 & 0 & 1 \\
\hline Teólogo & 1 & 0 & 0 & 0 & 0 & 1 \\
\hline Tradutor & 0 & 0 & 1 & 0 & 0 & 1 \\
\hline Veterinário & 0 & 0 & 1 & 0 & 0 & 1 \\
\hline tal & 171 & 75 & 247 & 323 & 38 & 854 \\
\hline
\end{tabular}

Fonte: Dados primários - Elaboração da própria autora, 2014 


\begin{tabular}{|c|c|c|c|c|c|c|}
\hline & \multicolumn{4}{|c|}{ Carreiras } & \multirow[b]{2}{*}{$\begin{array}{l}\text { TPP- } \\
\text { Ipea }\end{array}$} & \multirow[b]{2}{*}{ Total } \\
\hline & Adv.União & APO & EPPGG & Procurador & & \\
\hline Nunca frequentou a escola & 10 & 1 & 2 & 5 & 0 & 18 \\
\hline $\begin{array}{l}\text { Até a } 4^{\mathrm{a}} \text { série do ensino } \\
\text { fundamental }\end{array}$ & 13 & 9 & 23 & 27 & 5 & 77 \\
\hline $\begin{array}{l}\text { Ensino fundamental } \\
\text { incompleto }\end{array}$ & 10 & 6 & 10 & 13 & 3 & 42 \\
\hline $\begin{array}{l}\text { Ensino fundamental } \\
\text { completo }\end{array}$ & 7 & 3 & 9 & 6 & 1 & 26 \\
\hline Ensino médio incompleto & 2 & 1 & 7 & 5 & 2 & 17 \\
\hline Ensino médio completo & 18 & 6 & 25 & 49 & 4 & 102 \\
\hline $\begin{array}{l}\text { Ensino superior } \\
\text { incompleto }\end{array}$ & 12 & 0 & 9 & 12 & 3 & 36 \\
\hline Ensino superior completo & 71 & 33 & 100 & 140 & 10 & 353 \\
\hline Pós-graduação & 28 & 16 & 62 & 66 & 10 & 182 \\
\hline Total & 171 & 75 & 247 & 323 & 38 & 853 \\
\hline
\end{tabular}

Tabela A11 - Número de carreiras por escolaridade da mãe

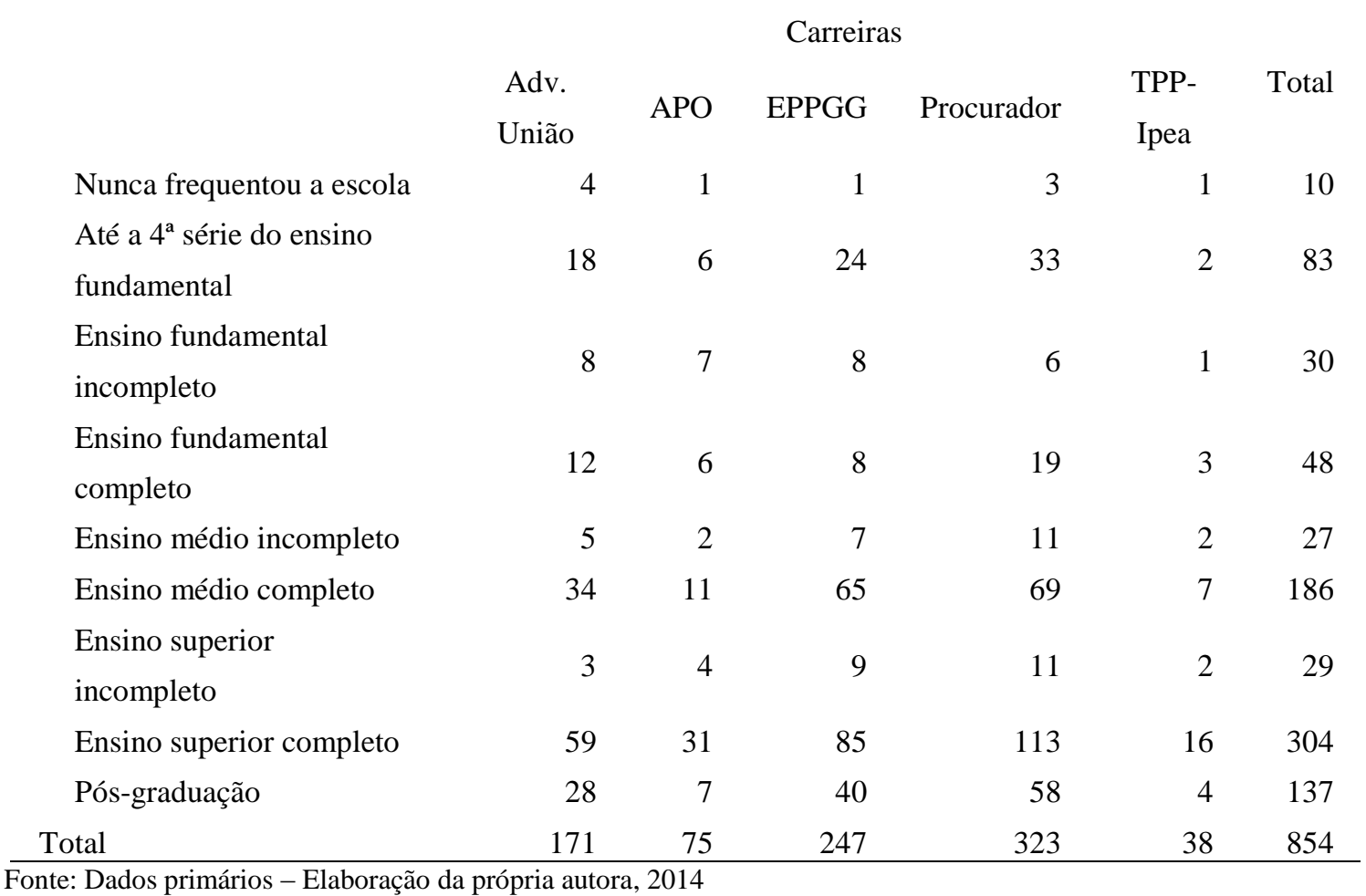


Tabela A12 - Metas físicas previstas e alcançadas dos programas do Orçamento da Igualdade Racial: 2008-2011 ${ }^{89}$ (unidade)

\begin{tabular}{|c|c|c|c|c|c|c|c|c|}
\hline \multirow{2}{*}{ Programas } & \multicolumn{2}{|c|}{2008} & \multicolumn{2}{|c|}{2009} & \multicolumn{2}{|c|}{2010} & \multicolumn{2}{|c|}{2011} \\
\hline & Previsão & Alcance & Previsão & Alcance & Previsão & Alcance & Previsão & Alcance \\
\hline Cultura afro-brasileira & 1.076 & 201 & 402 & 205 & 259 & 272 & 400 & 256 \\
\hline Comunidades tradicionais & 6.972 & 3.099 & 8.823 & 2.235 & 6.876 & 1.766 & 18.270 & 9.347 \\
\hline Saneamento rural & 28.121 & 43.081 & 13.177 & 8.744 & 4.761 & 2.514 & 9.087 & 823 \\
\hline Brasil quilombola & 102.845 & 101.069 & 61.002 & 11.285 & 70.317 & 45.018 & 63.312 & 21.163 \\
\hline Educação para a diversidade e cidadania & 13.445 & 1.644 & 8.289 & 9.447 & 37.824 & 727 & 50.180 & 871 \\
\hline $\begin{array}{l}\text { Assistência Técnica e extensão rural na agricultura } \\
\text { familiarc }\end{array}$ & 1.894 .915 & 1.225 .658 & 2.271 .576 & 2.231 .351 & 2.893 .202 & 501.105 & 364.089 & 316.438 \\
\hline $\begin{array}{l}\text { Promoção de políticas afirmativas para a igualdade } \\
\text { racial }\end{array}$ & 1.323 & 123 & 1.480 & 510 & 2.255 & 54 & 3.081 & 617 \\
\hline
\end{tabular}

Fonte: SPI/MP, em 12/09/12. Elaboração própria, 2014

CulturaAfr = Cultura afro-brasileira; ComTrad = Comunidades tradicionais;SanRural = Saneamento Rural; BrQuilom = Brasil quilombola; Educação = Educação para a diversidade e cidadania; AssisTec $=$ Assistência técnica e extensão rural na agricultura familiar; PromPolAf = Promoção de políticas afirmativas para igualdade racial .

${ }^{89}$ Para a construção desses dados, somaram-se as unidades de medidas de todas as ações orçamentárias desses programas. Utilizaram-se as unidades de medidas padronizadas, ou seja, unidades. Aquelas ações que tinham outras unidades de medida não foram consideradas nesta tabela, como por exemplo, \% de execução física; hectare. 
Tabela A13 - Evolução de indicadores para igualdade racial

(continua)

\begin{tabular}{|c|c|c|c|c|c|c|}
\hline Área temática e indicadores & & 2004 & & & 2011 & \\
\hline Educação & Negros & Brancos & Brasil & Negros & Brancos & Brasil \\
\hline $\begin{array}{l}\text { Taxa de Analfabetismo (15 anos ou mais) } \\
(\%)\end{array}$ & 16,3 & 7,2 & 11,5 & 11,8 & 5,3 & 8,6 \\
\hline $\begin{array}{l}\text { Taxa de frequência na escola ( } 0 \text { a } 3 \text { anos }) \\
\%\end{array}$ & 11,5 & 15,2 & 13,4 & 18,3 & 23,3 & 20,8 \\
\hline $\begin{array}{l}\text { Taxa de frequência na escola (15 a } 17 \\
\text { anos) }(\%)\end{array}$ & 78,9 & 85,2 & 81,9 & 82,5 & 85,4 & 83,7 \\
\hline $\begin{array}{l}\text { Taxa de frequência bruta na educação } \\
\text { superior }(\%)\end{array}$ & 10,3 & 27 & 18,6 & 19,5 & 37,6 & 27,8 \\
\hline $\begin{array}{l}\text { Média de anos de estudo ( } 15 \text { anos ou } \\
\text { mais) em anos }\end{array}$ & 5,8 & 7,7 & 6,8 & 6,9 & 8,5 & 7,7 \\
\hline \multicolumn{7}{|l|}{ Trabalho } \\
\hline $\begin{array}{l}\text { \% da população com } 16 \text { anos ou mais } \\
\text { desocupada na semana de referência }\end{array}$ & 9,8 & 7,8 & 8,7 & 7,4 & 5,7 & 6,6 \\
\hline $\begin{array}{l}\text { Rendimento mensal médio de todos os } \\
\text { trabalhos }(\mathrm{R} \$)\end{array}$ & 626,39 & 1219,91 & 945,9 & 927,9 & 1594,91 & 1259,42 \\
\hline $\begin{array}{l}\text { Taxa de formalidade das pessoas } \\
\text { ocupadas de } 16 \text { anos ou mais (\%) }\end{array}$ & 38,8 & 55,1 & 47,5 & 50,3 & 64,2 & 57,1 \\
\hline \multicolumn{7}{|l|}{ Distribuição de renda } \\
\hline $\begin{array}{l}\text { \% da população em situação de extrema } \\
\text { pobreza }\end{array}$ & 11 & 4 & 7,4 & 5,7 & 2,5 & 4,2 \\
\hline \% da população em situação de pobreza & 20,1 & 9 & 14,3 & 8,9 & 3,5 & 6,3 \\
\hline \multicolumn{7}{|l|}{ Previdência } \\
\hline $\begin{array}{l}\text { Cobertura previdenciária entre os idosos } \\
\text { com } 60 \text { anos ou mais }(\%)\end{array}$ & 80,3 & 83 & 81,9 & 81,6 & 84,3 & 83 \\
\hline $\begin{array}{l}\text { Proteção previdenciária da população } \\
\text { ocupada (16 a } 59 \text { anos) }(\%)\end{array}$ & 57,5 & 67,6 & 62,8 & 66 & 75,5 & 70,7 \\
\hline \multicolumn{7}{|l|}{ Trabalho Infantil } \\
\hline $\begin{array}{l}\% \text { de crianças/adolescentes de } 7 \text { a } 14 \text { anos } \\
\text { trabalhando }\end{array}$ & 8,3 & 5,5 & 7 & 4,9 & 3,2 & 4,2 \\
\hline \multicolumn{7}{|l|}{ Saneamento básico } \\
\hline $\begin{array}{l}\text { \% de pessoas que vivem em domicílios } \\
\text { com água canalizada em pelo menos um } \\
\text { cômodo } \\
\% \text { de pessoas que vivem em domicílios } \\
\text { com escoadouro do banheiro ou sanitário } \\
\text { por rede coletora ou fossa séptica }\end{array}$ & 80,4 & 94,4 & 87,6 & 90,1 & 97 & 93,4 \\
\hline
\end{tabular}


Tabela A13 - Evolução de indicadores para igualdade racial

(conclusão)

\begin{tabular}{lrrrrrr}
\hline Acesso a bens & & & & & & \\
\hline $\begin{array}{l}\text { \% de pessoas que vivem em domicílios } \\
\text { com máquina de lavar roupas }\end{array}$ & 19,2 & 46,2 & 33,3 & 38,5 & 64,3 & 51 \\
$\begin{array}{l}\text { \% de pessoas que vivem em domicílios } \\
\text { com telefone fixo ou móvel }\end{array}$ & 21,8 & 40,9 & 31,7 & 28,6 & 46,9 & 37,5 \\
$\begin{array}{l}\text { \% de pessoas que vivem em domicílios } \\
\begin{array}{l}\text { com microcomputador com acesso à } \\
\text { internet }\end{array}\end{array}$ & 5 & 18,2 & 11,9 & 28,1 & 48,7 & 38,1
\end{tabular}

\begin{tabular}{lllllll}
\hline Violência & & & & & & \\
\hline $\begin{array}{l}\text { Taxa de homicídio de jovens do sexo } \\
\text { masculino de 15 a 29 anos por 100 mil } \\
\text { habitantes (\%) }\end{array}$ & 122,97 & 67,62 & 102,8 & 135,07 & 52,75 & 103,5
\end{tabular}

\begin{tabular}{|c|c|c|c|c|c|c|}
\hline Mulheres & & & & & & \\
\hline $\begin{array}{l}\text { Rendimento mensal médio de todos os } \\
\text { trabalhos das mulheres de } 16 \text { anos ou } \\
\text { mais de idade }(\mathrm{R} \$ \text { ) }\end{array}$ & 466 & 895 & 704 & 739 & 1258 & 1009 \\
\hline \multicolumn{7}{|l|}{ Juventude } \\
\hline $\begin{array}{l}\text { \% das populações de } 18 \text { a } 24 \text { anos que } \\
\text { não estuda, não trabalha, nem está } \\
\text { procurando emprego }\end{array}$ & 16 & 13 & 14,6 & 18,1 & 13,8 & 16,2 \\
\hline $\begin{array}{l}\% \text { das populações de } 25 \text { a } 29 \text { anos que } \\
\text { não estuda, não trabalha, nem está } \\
\text { procurando emprego }\end{array}$ & 16,9 & 14,4 & 15,7 & 17,5 & 13,7 & 15,7 \\
\hline
\end{tabular}


Tabela A14 - Evolução de indicadores para igualdade racial: amplitude dos indicadores entre negros e brancos e entre negros e Brasil

(continua)

\begin{tabular}{|c|c|c|c|c|}
\hline \multirow{3}{*}{ Área temática e indicadores } & \multicolumn{4}{|c|}{$\begin{array}{l}\text { Amplitude entre negros e brancos e entre negros e } \\
\text { Brasil }\end{array}$} \\
\hline & \multicolumn{2}{|c|}{ negros e brancos } & \multicolumn{2}{|c|}{ Brasil } \\
\hline & 2004 & 2011 & 2004 & 2011 \\
\hline \multicolumn{5}{|l|}{ Educação } \\
\hline Taxa de Analfabetismo (15 anos ou mais) $\%$ & 9,1 & 6,5 & 4,8 & 3,2 \\
\hline Taxa de frequência na escola ( 0 a 3 anos) $\%$ & $-3,7$ & -5 & $-1,9$ & $-2,5$ \\
\hline Taxa de frequência na escola (15 a 17 anos) \% & $-6,3$ & $-2,9$ & -3 & $-1,2$ \\
\hline $\begin{array}{l}\text { Taxa de frequência bruta na educação superior } \\
\%\end{array}$ & $-16,7$ & $-18,1$ & $-8,3$ & $-8,3$ \\
\hline $\begin{array}{l}\text { Média de anos de estudo (15 anos ou mais) em } \\
\text { anos }\end{array}$ & $-1,9$ & $-1,6$ & -1 & $-0,8$ \\
\hline \multicolumn{5}{|l|}{ Trabalho } \\
\hline $\begin{array}{l}\text { População com } 16 \text { anos ou mais desocupada na } \\
\text { semana de referência }(\%)\end{array}$ & 2 & 1,7 & 1,1 & 0,8 \\
\hline $\begin{array}{l}\text { Rendimento mensal médio de todos os trabalhos } \\
\text { (R\$) }\end{array}$ & -594 & $-667,01$ & $-319,47$ & $-331,52$ \\
\hline $\begin{array}{l}\text { Taxa de formalidade das pessoas ocupadas de } \\
16 \text { anos ou mais }(\%)\end{array}$ & $-16,3$ & $-13,9$ & $-8,7$ & $-6,8$ \\
\hline \multicolumn{5}{|l|}{ Distribuição de renda } \\
\hline \% da população em situação de extrema pobreza & 7 & 3,2 & 3,6 & 1,5 \\
\hline \% da população em situação de pobreza & 11,1 & 5,4 & 5,8 & 2,6 \\
\hline \multicolumn{5}{|l|}{ Previdência } \\
\hline $\begin{array}{l}\text { Cobertura previdenciária entre os idosos com } 60 \\
\text { anos ou mais }(\%)\end{array}$ & $-2,7$ & $-2,7$ & $-1,6$ & $-1,4$ \\
\hline $\begin{array}{l}\text { Proteção previdenciária da população ocupada } \\
\text { (16 a } 59 \text { anos) }(\%)\end{array}$ & $-10,1$ & $-9,5$ & $-5,3$ & $-4,7$ \\
\hline \multicolumn{5}{|l|}{ Trabalho Infantil } \\
\hline $\begin{array}{l}\text { Percentual de crianças/adolescentes de } 7 \text { a } 14 \\
\text { anos trabalhando }\end{array}$ & 2,8 & 1,7 & 1,3 & 0,7 \\
\hline
\end{tabular}


Tabela A14 - Evolução de indicadores para igualdade racial: amplitude dos indicadores entre negros e brancos e entre negros e Brasil

(conclusão)

\begin{tabular}{|c|c|c|c|c|}
\hline Saneamento básico & & & & \\
\hline $\begin{array}{l}\% \text { de pessoas que vivem em domicílios com } \\
\text { água canalizada em pelo menos um cômodo }\end{array}$ & -14 & $-6,9$ & $-7,2$ & $-3,3$ \\
\hline $\begin{array}{l}\text { \% de pessoas que vivem em domicílios com } \\
\text { escoadouro do banheiro ou sanitário por rede } \\
\text { coletora ou fossa séptica }\end{array}$ & $-16,2$ & $-11,7$ & $-8,7$ & $-5,7$ \\
\hline Acesso a bens & & & & \\
\hline $\begin{array}{l}\% \text { de pessoas que vivem em domicílios com } \\
\text { máquina de lavar roupas }\end{array}$ & -27 & $-25,8$ & $-14,1$ & $-12,5$ \\
\hline $\begin{array}{l}\text { \% de pessoas que vivem em domicílios com } \\
\text { telefone fixo ou móvel }\end{array}$ & $-19,1$ & $-18,3$ & $-9,9$ & $-8,9$ \\
\hline $\begin{array}{l}\text { \% de pessoas que vivem em domicílios com } \\
\text { microcomputador com acesso à internet }\end{array}$ & $-13,2$ & $-20,6$ & $-6,9$ & -10 \\
\hline
\end{tabular}

Violência

Taxa de homicídio de jovens do sexo masculino de 15 a 29 anos por 100 mil habitantes

$55,35 \quad 82,32 \quad 20,19$

31,62

\section{Mulheres}

Rendimento mensal médio de todos os trabalhos das mulheres de 16 anos ou mais de idade (R\$)

$\begin{array}{lll}-429 & -519 & -238\end{array}$

$-270$

\begin{tabular}{lcccc} 
& 0 & 0 & 0 & 0 \\
\hline Juventude & 0 & 0 & 0 & 0 \\
\hline $\begin{array}{l}\text { \% das populações de 18 a 24 anos que não } \\
\text { estuda, não trabalha, nem está procurando } \\
\text { emprego }\end{array}$ & 3 & 4,3 & 1,4 & 1,9 \\
$\begin{array}{l}\text { \% das populações de 25 a 29 anos que não } \\
\text { estuda, não trabalha, nem está procurando } \\
\text { emprego }\end{array}$ & 2,5 & 3,8 & 1,2 & 1,8
\end{tabular}

Fonte: Elaboração própria. Fonte primária Plano Mais Brasil PPA 2012-2015: agendas transversais - monitoramento participativo: ano base 2012/Ministério do Planejamento, Orçamento e Gestão - p.29 
Tabela A15 - Evolução de indicadores para igualdade racial: amplitude dos indicadores intragrupos - 2004 e 2011

(continua)

\begin{tabular}{|c|c|c|}
\hline Área temática e indicadores & Negros & Brancos \\
\hline \multicolumn{3}{|l|}{ Educação } \\
\hline Taxa de Analfabetismo (15 anos ou mais) $\%$ & $-27,6$ & $-26,4$ \\
\hline Taxa de frequência na escola ( 0 a 3 anos) $\%$ & 59,1 & 53,3 \\
\hline Taxa de frequência na escola ( 15 a 17 anos) $\%$ & 4,6 & 0,2 \\
\hline Taxa de frequência bruta na educação superior \% & 89,3 & 39,3 \\
\hline Média de anos de estudo (15 anos ou mais) em anos & 19,0 & 10,4 \\
\hline \multicolumn{3}{|l|}{ Trabalho } \\
\hline $\begin{array}{l}\text { População com } 16 \text { anos ou mais desocupada na semana de } \\
\text { referência }(\%)\end{array}$ & $-24,5$ & $-26,9$ \\
\hline Rendimento mensal médio de todos os trabalhos $(\mathrm{R} \$)$ & 48,1 & 30,7 \\
\hline $\begin{array}{l}\text { Taxa de formalidade das pessoas ocupadas de } 16 \text { anos ou } \\
\text { mais }(\%)\end{array}$ & 29,6 & 16,5 \\
\hline
\end{tabular}

\begin{tabular}{|c|c|c|}
\hline Distribuição de renda & & \\
\hline \% da população em situação de extrema pobreza & $-48,2$ & $-37,5$ \\
\hline \% da população em situação de pobreza & $-55,7$ & $-61,1$ \\
\hline \multicolumn{3}{|l|}{ Previdência } \\
\hline $\begin{array}{l}\text { Cobertura previdenciária entre os idosos com } 60 \text { anos ou } \\
\text { mais }(\%)\end{array}$ & 1,6 & 1,6 \\
\hline $\begin{array}{l}\text { Proteção previdenciária da população ocupada (16 a } 59 \\
\text { anos) }(\%)\end{array}$ & 14,8 & 11,7 \\
\hline \multicolumn{3}{|l|}{ Trabalho Infantil } \\
\hline $\begin{array}{l}\text { Percentual de crianças/adolescentes de } 7 \text { a } 14 \text { anos } \\
\text { trabalhando }\end{array}$ & $-41,0$ & $-41,8$ \\
\hline
\end{tabular}

Saneamento básico

$\%$ de pessoas que vivem em domicílios com água canalizada em pelo menos um cômodo

$\%$ de pessoas que vivem em domicílios com escoadouro do banheiro ou sanitário por rede coletora ou fossa séptica 
Tabela A15 - Evolução de indicadores para igualdade racial: amplitude dos indicadores intragrupos - 2004 e 2011

(conclusão)

\begin{tabular}{|c|c|c|}
\hline Acesso a bens & & \\
\hline $\begin{array}{l}\text { \% de pessoas que vivem em domicílios com máquina de } \\
\text { lavar roupas }\end{array}$ & 100,5 & 39,2 \\
\hline $\begin{array}{l}\% \text { de pessoas que vivem em domicílios com telefone fixo } \\
\text { ou móvel }\end{array}$ & 31,2 & 14,7 \\
\hline $\begin{array}{l}\% \text { de pessoas que vivem em domicílios com } \\
\text { microcomputador com acesso à internet }\end{array}$ & 462,0 & 167,6 \\
\hline \multicolumn{3}{|l|}{ Violência } \\
\hline $\begin{array}{l}\text { Taxa de homicídio de jovens do sexo masculino de } 15 \text { a } 29 \\
\text { anos por } 100 \text { mil habitantes }\end{array}$ & 9,8 & $-22,0$ \\
\hline \multicolumn{3}{|l|}{ Mulheres } \\
\hline $\begin{array}{l}\text { Rendimento mensal médio de todos os trabalhos das } \\
\text { mulheres de } 16 \text { anos ou mais de idade (R\$) }\end{array}$ & 58,6 & 40,6 \\
\hline \multicolumn{3}{|l|}{ Juventude } \\
\hline $\begin{array}{l}\% \text { das populações de } 18 \text { a } 24 \text { anos que não estuda, não } \\
\text { trabalha, nem está procurando emprego }\end{array}$ & 13,1 & 6,2 \\
\hline $\begin{array}{l}\% \text { das populações de } 25 \text { a } 29 \text { anos que não estuda, não } \\
\text { trabalha, nem está procurando emprego }\end{array}$ & 3,6 & $-4,9$ \\
\hline
\end{tabular}

Fonte: Elaboração própria. Fonte primária Plano Mais Brasil PPA 2012-2015: agendas transversais - monitoramento participativo: ano base 2012/Ministério do Planejamento, Orçamento e Gestão - p.29 


\section{Quadro A1 - Perfil sociodemográfico dos servidores das carreiras entrevistados}

(continua)

\begin{tabular}{|c|c|c|c|c|c|c|c|c|c|c|}
\hline Entrevistado & 1 & 2 & 3 & 4 & 5 & 6 & 7 & 8 & 9 & 10 \\
\hline Carreira & EPPGG & EPPGG & EPPGG & Procurador & Adv.União & TPP & TPP & Adv. União & Procurador & Adv. União \\
\hline Sexo & $\mathrm{F}$ & $\mathrm{M}$ & $\mathrm{M}$ & $\mathrm{M}$ & $\mathrm{F}$ & $\mathrm{M}$ & $\mathrm{F}$ & $\mathrm{M}$ & $\mathrm{M}$ & $\mathrm{M}$ \\
\hline Nascimento & 1985 & 1970 & 1975 & 1979 & 1980 & 1967 & 1962 & 1979 & 1981 & 1966 \\
\hline Cor/Raça & Parda & Branca & Branca & Branca & Parda & Parda & Parda & ND & Branca & Branca \\
\hline $\begin{array}{l}\text { Curso } \\
\text { Superior }\end{array}$ & $\begin{array}{l}\text { Rel.Internacio } \\
\text { nais }\end{array}$ & Economia & $\begin{array}{l}\text { Adm.Empres } \\
\text { a }\end{array}$ & Direito & Direito & Economia & $\begin{array}{l}\text { Rel.Internacio } \\
\text { nais } \\
\text { Economia }\end{array}$ & Direito & Direito & Direito \\
\hline $\begin{array}{l}\text { Pós- } \\
\text { graduação }\end{array}$ & $\begin{array}{l}\text { Mest.Desenv. } \\
\text { Sustentável }\end{array}$ & $\begin{array}{l}\text { Mest.Econom } \\
\text { ia }\end{array}$ & $\begin{array}{l}\text { Mest. } \\
\text { Sociologia }\end{array}$ & Mest. Direito & Esp. Direito & $\begin{array}{l}\text { Mest. } \\
\text { Economia }\end{array}$ & $\begin{array}{l}\text { Dout.Econom } \\
\text { ia }\end{array}$ & Mest.Direito & Não & Mest. Direito \\
\hline $\begin{array}{l}\text { IngressoCarr } \\
\text { eira }\end{array}$ & 2009 & 2004 & 2001 & 2003 & 2005 & 1997 & 1987 & 2005 & 2008 & 2001 \\
\hline $\begin{array}{l}\text { Área } \\
\text { trabalho }\end{array}$ & 6 & 3 & 7 & 5 & 7 & 7 & 7 & 4 & 1 & 4 \\
\hline
\end{tabular}


Quadro A1 - Perfil sociodemográfico dos servidores das carreiras entrevistados

(continuação)

\begin{tabular}{|c|c|c|c|c|c|c|c|c|c|c|}
\hline Entrevistado & 1 & 2 & 3 & 4 & 5 & 6 & 7 & 8 & 9 & 10 \\
\hline $\begin{array}{l}\text { Cargo } \\
\text { Comissão }\end{array}$ & Não & DAS-4 & Não & DAS-2 & Não & Não & Sim & Não & DAS-2 & Não \\
\hline $\begin{array}{l}\text { Cargo } \\
\text { Comissão } \\
\text { 2007-2012 }\end{array}$ & $\begin{array}{l}\text { DAS-1 } \\
\text { DAS-4 }\end{array}$ & $\begin{array}{l}\text { DAS-3 } \\
\text { DAS-4 }\end{array}$ & Não & DAS-1 & DAS-2 & DAS-1 & Não & DAS-4 & DAS-2 & Não \\
\hline $\begin{array}{l}\text { Associativism } \\
\text { o }\end{array}$ & Sim & Sim & Sim & Não & Sim & Sim & Sim & Sim & Sim & Não \\
\hline Cor/Raça Pai & Preta & Parda & Branca & Branca & Parda & Parda & Parda & Branca & Branca & Branca \\
\hline $\begin{array}{l}\text { Cor/Raça } \\
\text { Mãe }\end{array}$ & Branca & Branca & Branca & Branca & Branca & Parda & Parda & Parda & Branca & Branca \\
\hline $\begin{array}{l}\text { Escolaridade } \\
\text { Pai }\end{array}$ & Mestrado & Superior & Fundamental & Mestrado & Superior & Médio & Superior & Superior & Mestrado & Fundamental \\
\hline $\begin{array}{l}\text { Escolaridade } \\
\text { Mãe }\end{array}$ & Superior & Mestrado & Fundamental & Mestrado & Superior & Superior & Superior & Superior & $\begin{array}{l}\text { Especializaçã } \\
\text { o }\end{array}$ & Fundamental \\
\hline Ocupação Pai & Geólogo & Serv.Público & Pescador & Engenheiro & Serv.Público & Comerciante & Serv.Público & Serv.Público & Engenheiro & Motorista \\
\hline $\begin{array}{l}\text { Ocupação } \\
\text { Mãe }\end{array}$ & Serv. Pública & Serv.Pública & Dona de Casa & Serv.Pública & Dona de Casa & Farmacêutica & Serv.Pública & Serv.Pública & Professora & Dona de Casa \\
\hline
\end{tabular}


Quadro A1 - Perfil sociodemográfico dos servidores das carreiras entrevistados

(continuação)

\begin{tabular}{|c|c|c|c|c|c|c|c|c|c|c|c|}
\hline Entrevistado & 11 & 12 & 13 & 14 & 15 & 16 & 17 & 18 & 19 & 20 & 21 \\
\hline Carreira & EPPGG & Adv. União & EPPGG & Procurador & Procurador & EPPGG & APO & APO & $\mathrm{APO}$ & APO & APO \\
\hline Sexo & $\mathrm{M}$ & $\mathrm{M}$ & $\mathrm{M}$ & $\mathrm{M}$ & $\mathrm{M}$ & $\mathrm{F}$ & $\mathrm{F}$ & $\mathrm{M}$ & $\mathrm{F}$ & $\mathrm{M}$ & $\mathrm{F}$ \\
\hline Nascimento & 1959 & 1945 & 1977 & 1967 & 1966 & 1965 & 1958 & 1967 & 1959 & 1987 & 1987 \\
\hline Cor/Raça & Branca & Preta & Branca & Amarela & Pardo & Branca & Amarela & Branca & Branca & Branca & Branca \\
\hline $\begin{array}{l}\text { Curso } \\
\text { Superior }\end{array}$ & Economia & Direito & Direito & Direito & Direito & Eng.Química & $\begin{array}{l}\text { Arquitetura e } \\
\text { Urbanismo }\end{array}$ & Matemática & $\begin{array}{l}\text { Ciências } \\
\text { Contábeis }\end{array}$ & $\begin{array}{l}\text { Rel.Intern } \\
\text { acionais }\end{array}$ & $\begin{array}{l}\text { Administra } \\
\text { ção de } \\
\text { Empresas }\end{array}$ \\
\hline $\begin{array}{l}\text { Pós- } \\
\text { graduação }\end{array}$ & $\begin{array}{l}\text { Mest.Ciência } \\
\text { Política }\end{array}$ & Esp. Direito & Espec. GGPP & Espec.Direito & Espec.Direito & $\begin{array}{l}\text { Doutorado } \\
\text { Gestão } \\
\text { Rec.Naturais }\end{array}$ & $\begin{array}{l}\text { Mest.Desenv. } \\
\text { Planj.Urbano }\end{array}$ & Não & Não & Não & Não \\
\hline $\begin{array}{l}\text { IngressoCarr } \\
\text { eira }\end{array}$ & 1988 & 2000 & 2007 & 1998 & 1998 & 2004 & 2011 & 2009 & 2000 & 2010 & 2011 \\
\hline $\begin{array}{l}\text { Área } \\
\text { trabalho }\end{array}$ & 3 & 4 & 1 & 5 & 1 & 2 & 3 & 3 & 1 & 3 & 3 \\
\hline $\begin{array}{l}\text { Cargo } \\
\text { Comissão }\end{array}$ & Não & Não & DAS-4 & DAS-4 & DAS-2 & DAS-5 & Não & Não & DAS-4 & Não & DAS-2 \\
\hline
\end{tabular}


Quadro A1 - Perfil sociodemográfico dos servidores das carreiras entrevistados

(conclusão)

\begin{tabular}{|c|c|c|c|c|c|c|c|c|c|c|c|}
\hline Entrevistado & 11 & 12 & 13 & 14 & 15 & 16 & 17 & 18 & 19 & 20 & 21 \\
\hline $\begin{array}{l}\text { Cargo } \\
\text { Comissão } \\
\text { 2007-2012 }\end{array}$ & $3 x$ DAS-4 & Não & DAS-4 & Não & DAS-2 & DAS-4 & Não & Não & $\begin{array}{l}\text { DAS-3 } \\
\text { DAS-4 }\end{array}$ & Não & Não \\
\hline $\begin{array}{l}\text { Associativism } \\
\text { o }\end{array}$ & Sim & Não & Sim & Sim & Sim & Sim & Sim & Não & Não & Não & Não \\
\hline Cor/Raça Pai & Branca & Preta & Branca & Preto & Parda & Branca & Parda & Branca & Branca & Branca & Branca \\
\hline $\begin{array}{l}\text { Cor/Raça } \\
\text { Mãe }\end{array}$ & Indígena & Preta & Branca & Parda & Parda & Branca & Branca & Branca & Branca & Branca & Branca \\
\hline $\begin{array}{l}\text { Escolaridade } \\
\text { Pai }\end{array}$ & Médio & Fundamental & Doutorado & Médio & Superior & Médio & Médio & Superior & Mestrado & Superior & $\begin{array}{l}\text { Especializa } \\
\text { ção }\end{array}$ \\
\hline $\begin{array}{l}\text { Escolaridade } \\
\text { Mãe }\end{array}$ & Médio & Fundamental & $\begin{array}{l}\text { Especializaçã } \\
\text { o }\end{array}$ & Médio & Fundamental & Superior & Médio & Superior & Fundamental & Superior & $\begin{array}{l}\text { Especializa } \\
\text { ção }\end{array}$ \\
\hline Ocupação Pai & Militar & Jardineiro & Professor & Comerciante & Proc. Federal & Motorista & Serv.Público & Engenheiro & $\begin{array}{l}\text { Professor } \\
\text { Universitário }\end{array}$ & $\begin{array}{l}\text { Engenheir } \\
\text { o }\end{array}$ & $\begin{array}{l}\text { Engenheir } \\
\text { o }\end{array}$ \\
\hline $\begin{array}{l}\text { Ocupação } \\
\text { Mãe }\end{array}$ & Serv.Pública & Doméstico & Serv.Pública & Dona de Casa & Costureira & Serv.Pública & Dona de Casa & Professora & Dona de Casa & Professora & $\begin{array}{l}\text { Serv.Públi } \\
\text { ca }\end{array}$ \\
\hline
\end{tabular}




\section{Anexo B}

\section{B1. Questionário aplicado on-line}

Obrigada por participar desta pesquisa

1. Gostaríamos de saber o quão de acordo você está com cada uma das seguintes funções do Estado.

\begin{tabular}{|c|c|c|c|c|c|c|}
\hline & & $\begin{array}{l}\text { 1.Concorda } \\
\text { muito }\end{array}$ & 2.Concorda & $\begin{array}{l}\text { 3.Não } \\
\text { concorda } \\
\text { nem } \\
\text { discorda }\end{array}$ & 4.Discorda & $\begin{array}{l}\text { 5.Discorda } \\
\text { muito }\end{array}$ \\
\hline 1 & $\begin{array}{l}\text { Que o Estado mantenha a ordem, pois as leis devem ser obedecidas sempre, mesmo } \\
\text { se forem injustas. }\end{array}$ & & & & & \\
\hline 2 & $\begin{array}{l}\text { Que o Estado garanta que as pessoas mais capacitadas sejam reconhecidas social e } \\
\text { economicamente mais do que as pessoas menos capazes. }\end{array}$ & & & & & \\
\hline 3 & $\begin{array}{l}\text { Que o Estado implemente políticas públicas para prover a igualdade social e } \\
\text { econômica entre as pessoas. }\end{array}$ & & & & & \\
\hline 4 & $\begin{array}{l}\text { Que o Estado proteja a todos, sem distinção socioeconômica, de forma a não } \\
\text { prejudicar quem venceu pelo próprio esforço. }\end{array}$ & & & & & \\
\hline 5 & Que se consiga resolver o problema dos mais pobres com o apoio do Estado. & & & & & \\
\hline 6 & $\begin{array}{l}\text { Que o Estado promova alianças com o empresariado para executar estratégias de } \\
\text { desenvolvimento nacional. }\end{array}$ & & & & & \\
\hline 7 & Que o Estado organize a sociedade civil para com ela executar políticas públicas. & & & & & \\
\hline 8 & $\begin{array}{l}\text { Que o Estado deixe o mercado coordenar a vida social porque assim se tornará mais } \\
\text { democrático. }\end{array}$ & & & & & \\
\hline 9 & $\begin{array}{l}\text { Que o Estado atenda as demandas dos cidadãos porque assim se tornará mais } \\
\text { democrático. }\end{array}$ & & & & & \\
\hline
\end{tabular}




\section{Gostaríamos de saber o quão de acordo você está com cada uma das seguintes propostas de políticas públicas}

\begin{tabular}{|c|c|c|c|c|c|c|}
\hline & & $\begin{array}{l}\text { 1.Concorda } \\
\text { muito }\end{array}$ & 2.Concorda & $\begin{array}{c}\text { 3.Não } \\
\text { concord } \\
\text { a nem } \\
\text { discord } \\
\text { a }\end{array}$ & 4.Discorda & $\begin{array}{c}5 . \\
\text { Discorda } \\
\text { muito }\end{array}$ \\
\hline 1 & $\begin{array}{l}\text { Que o Estado gaste mais dinheiro nas creches e escolas localizadas em áreas onde a maioria dos } \\
\text { moradores é da população negra.* }\end{array}$ & & & & & \\
\hline 2 & $\begin{array}{l}\text { Que o Estado gaste mais dinheiro nas creches e escolas localizadas em áreas pobres como forma de } \\
\text { diminuir a pobreza }\end{array}$ & & & & & \\
\hline 3 & $\begin{array}{l}\text { Que o Estado gaste mais dinheiro apoiando cursinhos pré-vestibulares promovidos por ONGs para } \\
\text { estudantes negros/as. }\end{array}$ & & & & & \\
\hline 4 & $\begin{array}{l}\text { Que o Estado gaste mais dinheiro apoiando cursinhos pré-vestibulares promovidos por ONGs para } \\
\text { estudantes pobres. }\end{array}$ & & & & & \\
\hline 5 & $\begin{array}{l}\text { Que o Estado estimule, financeiramente, as Instituições de Ensino Superior Públicas a implantar } \\
\text { programas para ampliar o acesso de estudantes negros/as ao ensino superior. }\end{array}$ & & & & & \\
\hline 6 & $\begin{array}{l}\text { Que o Estado estimule, financeiramente, as Instituições de Ensino Superior Públicas a implantar } \\
\text { programas para ampliar o acesso de estudantes pobres ao ensino superior. }\end{array}$ & & & & & \\
\hline 7 & $\begin{array}{l}\text { Que o Estado gaste mais dinheiro nas unidades de saúde localizadas nas áreas em que a maioria dos } \\
\text { moradores é de da população negra. }\end{array}$ & & & & & \\
\hline 8 & $\begin{array}{l}\text { Que o Estado gaste mais dinheiro nas unidades de saúde localizadas nas áreas pobres como forma de } \\
\text { diminuir a pobreza. }\end{array}$ & & & & & \\
\hline 9 & $\begin{array}{l}\text { Que o Estado institua um fundo orçamentário e financeiro para a implementação de políticas que } \\
\text { possam elevar a condição socioeconômica da população negra no Brasil. }\end{array}$ & & & & & \\
\hline 10 & $\begin{array}{l}\text { Que o Estado institua um fundo orçamentário e financeiro para a implementação de políticas que } \\
\text { possam elevar a condição socioeconômica da população pobre no Brasil. }\end{array}$ & & & & & \\
\hline 11 & $\begin{array}{l}\text { Que o Estado incentive financeiramente as entidades culturais e esportivas localizadas nas áreas em que } \\
\text { a maioria dos moradores é da população negra. }\end{array}$ & & & & & \\
\hline 12 & $\begin{array}{l}\text { Que o Estado incentive financeiramente as entidades culturais e esportivas localizadas nas áreas pobres } \\
\text { como forma de diminuir a pobreza. }\end{array}$ & & & & & \\
\hline 13 & $\begin{array}{l}\text { Que o Estado incentive as empresas a construírem fábricas em áreas onde a maioria dos moradores é de } \\
\text { da população negra.* }\end{array}$ & & & & & \\
\hline 14 & $\begin{array}{l}\text { Que o Estado incentive as empresas a construírem fábricas em áreas pobres como forma de diminuir a } \\
\text { pobreza. }\end{array}$ & & & & & \\
\hline 15 & Que o Estado reserve vagas nos concursos públicos para pessoas negros/as. & & & & & \\
\hline 16 & Que o Estado reserve vagas nos concursos públicos para pessoas pobres. & & & & & \\
\hline
\end{tabular}




\section{Concluindo}

Gostaríamos de saber um pouco sobre você para melhor caracterizar os respondentes desta pesquisa

3. Qual é o nome da Carreira a que você pertence?

○ Advogado da União

- Analista de Finanças e Controle

- Analista de Planejamento e Orçamento

- Delegado da Polícia Federal

- Especialista em Políticas Públicas e Gestão Governamental

- Procurador Federal

- Técnico de Pesquisa e Planejamento do Ipea

4. Sexo:

○ Feminino

- Masculino

5. Ano de nascimento:

6. Você se considera de cor ou raça:

- Branca

- Preta

- Amarela

- Parda

- Indígena

7. Qual foi o curso superior em que você se graduou?

8. Você possui pós-graduação? Marque o nível mais elevado entre as opções abaixo.

○ Não.

○ Especialização

- Mestrado

- Doutorado

- Pós-doutorado 
9. Qual a área de sua pós-graduação?

10. Ano de ingresso na atual carreira?

11. Hoje, a instituição em que você trabalha atua na:

- Área social

- Área de infraestrutura

- Área econômica, de planejamento, de auditoria ou de controle

○ Outro. Especifique:

12. Atualmente, você está trabalhando:

○ No Distrito Federal

○ Em outro Estado da Federação

13. Atualmente, exerce algum cargo em comissão?

Não.

- DAS 101.1

- DAS 102.1

- DAS 101.2

- DAS 102.2

- DAS 101.3

- DAS 102.3

- DAS 101.4

- DAS 102.4

- DAS 101.5

○ DAS 102.5

- DAS 101.6

- DAS 102.6

- Natureza Especial

14. Entre o período de 2007 a 2012, você exerceu algum cargo em comissão? ('Por favor, se mais de um, registrar).

15. Referente ao item anterior, qual era a área de atuação da instituição onde você exerceu o cargo em comissão entre o período de 2007 a 2012? (Se mais de uma instituição, por favor, registre e indique qual foi o nível do/dos cargo/cargos em comissão exercido/s). 
16. Você faz parte ou já participou de algumas destas entidades ou grupos:

\begin{tabular}{|l|c|c|c|}
\hline \multicolumn{2}{|c|}{ ENTIDADE/GRUPO } & FAZ & JÁ \\
PARTE & PARTICIPOU & NUNCA \\
PARTICIPOU
\end{tabular}

17. Você se considera membro da elite do serviço público brasileiro?

$\begin{array}{ll}\text { ○ } & \text { Sim } \\ \circ & \text { Não } \\ \circ & \text { Outro. Especifique: }\end{array}$

18. Você participa de processos decisório para a formulação e/ou implementação de políticas públicas?

○ Sim

○ Não

○ Outro. Especifique:

Gostaríamos de fazer algumas perguntas sobre os seus pais.

19. Você considera que a cor ou raça de seu pai é:
- Branca
- Preta
- Amarela
- Parda
Indígena

20. Você considera que a cor ou raça de sua mãe é:
- Branca
- Preta
- Amarela
- Parda
- Indígena 
21. Qual é a escolaridade mais elevada de seu pai?

- Nunca frequentou a escola

- Até a $4^{\mathrm{a}}$ série do ensino fundamental

- Ensino fundamental incompleto

○ Ensino fundamental completo

○ Ensino médio incompleto

- Ensino médio completo

- Curso superior incompleto

- Curso superior completo

○ Pós-graduação

22. Qual é a escolaridade mais elevada de sua mãe?

- Nunca frequentou a escola

- Até a $4^{\mathrm{a}}$ série do ensino fundamental

- Ensino fundamental incompleto

- Ensino fundamental completo

- Ensino médio incompleto

- Ensino médio completo

- Curso superior incompleto

- Curso superior completo

○ Pós-graduação

23. Qual é/era a profissão do seu pai?

24. Qual é/era a profissão de sua mãe? 


\section{B2. Questões aplicadas na entrevista presencial}

\section{Roteiro de entrevista 1}

Entrevistados: Servidores das carreiras a Analista de Planejamento e Orçamento, Especialista em Políticas Públicas e Gestão Governamental, Técnico de Pesquisa e Planejamento do Instituto de Pesquisa Econômica Aplicada-Ipea, Advogado da União e Procurador Federal.

(Apresentação)

Conforme conversamos ao telefone, a minha pesquisa é sobre as relações entre as políticas sociais, políticas de promoção da igualdade racial e a burocracia brasileira.

O sr./sra. não será identificado(a), suas respostas serão confidenciais e anônimas. As opiniões de todos os respondentes serão somadas e incluídas no estudo, mas nunca serão informados dados individuais. Tudo que desejamos é conhecer a sua percepção.

1. Primeiramente, o sr./sra. poderia me fornecer algumas informações sobre você para melhor caracterizar os respondentes desta pesquisa

a) Carreira:

b) Sexo:

c) Ano de nascimento:

d) Qual é a sua cor ou raça (classificação do IBGE: branca, preta, amarela, parda, indígena)

e) Qual foi o curso superior em que você se graduou?

f) Possui pós-graduação? Se afirmativo, qual nível e área?

g) Ano de ingresso na atual Carreira?

h) Local atual de trabalho? Setorial de políticas sociais/ Setorial de infraestrutura/Órgãos Centrais planejamento, econômica ou controle

i) Atualmente, exerce algum cargo em comissão? Se afirmativo, qual? 
j) Nos últimos seis anos(2007-2012), exerceu algum cargo em comissão? (Perguntar se exerceu mais de um no período e qual o nível).

k) Referente ao item anterior, qual foi o local onde exerceu o cargo em comissão nos últimos 06 anos? Perguntar se exerceu mais de um no período e qual nível). Setorial de políticas sociais/ Setorial de infraestrutura/Órgãos Centrais planejamento, econômica ou controle

1) Você faz parte ou já participou de algumas destas entidades ou grupos:

\begin{tabular}{|l|}
\hline ENTIDADE/GRUPO \\
\hline Associação de defesa do consumidor \\
\hline Grupo de defesa do meio ambiente ou ecológico \\
\hline Sindicato ou associação profissional \\
\hline Centro acadêmico, grêmio ou união de estudantes \\
\hline Clube esportivo \\
\hline Grupo de solidariedade, de conscientização ou de multiplicadores \\
\hline Grupo religioso \\
\hline Torcida organizada \\
\hline Movimento de direitos humanos \\
\hline Trabalho voluntário \\
\hline
\end{tabular}

m) Qual é a cor ou raça de seu pai? (classificação do IBGE: branca, preta, amarela, parda, indígena)

n) Qual é a cor ou raça de sua mãe? (classificação do IBGE: branca, preta, amarela, parda, indígena)

o) Qual é a escolaridade mais elevada de seu pai?

p) Qual é a escolaridade mais elevada de sua mãe?

q) Qual é/era a ocupação do seu pai?

r) Qual é/era a ocupação de sua mãe?

s) Qual é o significado de você ocupar esse cargo?

t) Você se considera pertencente a uma elite do serviço público?

u) Você participa de decisões para formulação e implementação de políticas públicas? 
2. O sr./sra. tem conhecimento sobre as políticas de promoção da igualdade racial que estão sendo desenvolvidas pelo Estado brasileiro? (Se negativo, explicar as principais propostas)

3. Como vê a implementação no Estado das políticas de promoção da igualdade racial? (por exemplo, é difícil a implementação? Possui estrutura orçamentária e material?)

4. O sr./sra. apoia políticas dessa natureza? (Explorar as razões se afirmativo ou negativo.)

5. Na sua opinião, qual deveria ser o papel do Estado?

6. Gostaria de saber a sua opinião sobre algumas possíveis ações do Estado( se apoia ou não e explorar o porquê): Concorda/Favorável?

a. O sr./sra. concorda que o que o Estado gaste mais dinheiro nas creches e escolas localizadas em áreas onde a maioria dos moradores é da população negra.

b. Que o Estado gaste mais dinheiro apoiando cursinhos pré-vestibulares promovidos por ONGs para estudantes negros/as.

c. Que o Estado reserve vagas nos concursos públicos para negros/as.

d. Que o Estado incentive as empresas a construírem fábricas em áreas pobres como forma de diminuir a pobreza.

e. Que o Estado estimule,financeiramente, as Instituições de Ensino Superior Públicas a implantar programas para ampliar o acesso de estudantes pobres no ensino superior.

f. Que o Estado gaste mais dinheiro nas unidades de saúde localizadas nas áreas pobres como forma de diminuir a pobreza. 


\title{
Roteiro de entrevista 2
}

Entrevistados: Gestores de políticas de promoção da igualdade racial

\author{
(Apresentação)
}

Conforme conversamos ao telefone, a minha pesquisa é sobre as relações entre as políticas sociais, políticas de promoção da igualdade racial e a burocracia brasileira.

O sr./sra. não será identificado(a), suas respostas serão confidenciais e anônimas. As opiniões de todos os respondentes serão somadas e incluídas no estudo, mas nunca serão informados dados individuais. Tudo que desejamos é conhecer a sua percepção.

7. Primeiramente, o sr./sra. poderia me fornecer algumas informações sobre você para melhor caracterizar os respondentes desta pesquisa

v) Tipo de vínculo com o serviço público(efetivo, comissionado, carreira):

w) Sexo:

x) Ano de nascimento:

y) Qual é a sua cor ou raça (classificação do IBGE: branca, preta, amarela, parda, indígena)

z) Qual foi o curso superior em que você se graduou?

aa) Possui pós-graduação? Se afirmativo, qual nível e área?

bb) Onde atuou como dirigente de políticas de promoção da igualdade racial? Qual era o seu cargo?

cc) Qual é a cor ou raça de seu pai? (classificação do IBGE: branca, preta, amarela, parda, indígena)

dd) Qual é a cor ou raça de sua mãe? (classificação do IBGE: branca, preta, amarela, parda, indígena)

ee) Qual é a escolaridade mais elevada de seu pai?

ff) Qual é a escolaridade mais elevada de sua mãe?

gg) Qual é/era a ocupação do seu pai?

hh) Qual é/era a ocupação de sua mãe? 
8. Como vê a implementação no Estado das políticas de promoção da igualdade racial? (por exemplo, é difícil a implementação? Possui estrutura financeira e material?)

9. O que é mais relevante para o avanço das políticas de promoção da igualdade racial no Estado e na sociedade? (estrutura material, financeira, apoio político, apoio técnico, articulação com os demais órgãos. Explorar a relação com a burocracia estatal).

10. O desenho da política é importante? O seu objetivo (cotas - elite ou igualar brancos e não brancos no ensino superior?) A definição do seu público alvo? Difícil identificá-lo (quem é negro e quem não é, rem relação a políticas para a população negra)

11. Acredita que há resistência no Estado? Em que setores e segmentos?

12. Como vê a natureza de transversalidade das políticas de promoção da igualdade racial?

13. Vê algum trabalho de coordenação entre os órgãos responsáveis pelas políticas de promoção da igualdade racial e os demais órgãos setoriais e centrais para se chegar a algum consenso? Vê dificuldades nessa relação?

14. Já esteve trabalhando com as seguintes carreiras no desenvolvimento de políticas de promoção da igualdade racial?
a. Advogado da União
b. Procurador Federal
c. Especialista em Políticas Públicas e Gestão Governamental (Gestor Governamental)
d. Técnico de Planejamento e Pesquisa do Ipea
e. Analista de Planejamento e Orçamento

15. Acredita que essas carreiras fazem parte de uma elite do serviço público? Por que?

16. Houve alguma dificuldade na relação de trabalho para atingir os objetivos da política. Acredita que essas carreiras tenham alguma relevância no processo de formulação e implementação de políticas públicas? E de políticas de promoção da igualdade racial?

17. Acredita que obstáculos encontrados ou facilidades se devam ao corpo burocrático técnico ou ao corpo político? Se for ao burocrático técnico, 
perguntar sobre o processo de decisão, pois se concentra e o exerce quem tem

DAS no Estado brasileiro. É quem realmente decide. Se corpo político, como então acredita que a burocracia técnica pode ajudar ou atrapalhar?

18. Na sua opinião, qual deveria ser o papel do Estado? 


\section{B.3 Termo de consentimento livre e esclarecido}

Prezado /Prezada,

Você está sendo convidado /convidada a participar de um estudo desenvolvido pelo Programa de Pósgraduação em Sociologia da Universidade de BrasíliaUnB.

A sua escolha foi aleatória por meio de um sorteio. Para confirmar a sua participação, por favor, leia o texto abaixo e clique em continuar.

Esta pesquisa tem como foco políticas públicas formuladas e implementadas no Estado brasileiro. Visamos analisar as relações entre as políticas sociais, políticas de promoção da igualdade racial e a alta burocracia brasileira.

Se concordar em participar, você responderá um questionário online, cujo tempo de preenchimento varia de 10 a 15 minutos. Você não será identificado, suas respostas serão confidenciais e anônimas. As opiniões de todos os respondentes serão somadas e incluídas no estudo, mas nunca serão informados dados individuais. Tudo que desejamos é conhecer a sua percepção. Sem o seu apoio, não há como produzir conhecimento que dê base para melhorar as políticas públicas brasileiras.

Por favor, se você aceitar participar, responda cuidadosamente e com sinceridade e não deixe respostas em branco. Não existem respostas certas ou erradas. Se tiver alguma dúvida, estarei à disposição para lhe atender no email: cidachagas2000@gmail.com .

Agradecemos a sua colaboração.

\section{Maria Aparecida Chagas Ferreira}

Doutoranda do Programa de Pósgraduação em Sociologia da UnB

Especialista em Políticas Públicas e Gestão Governamental

(61) 81817180 